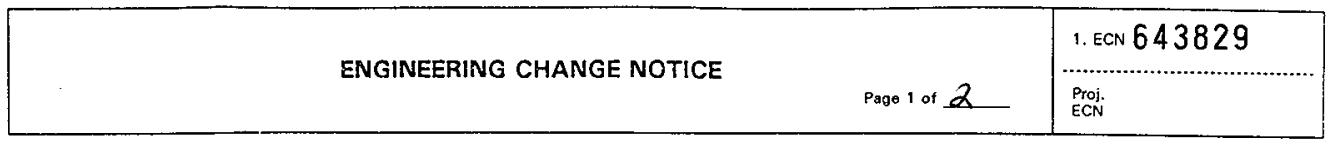

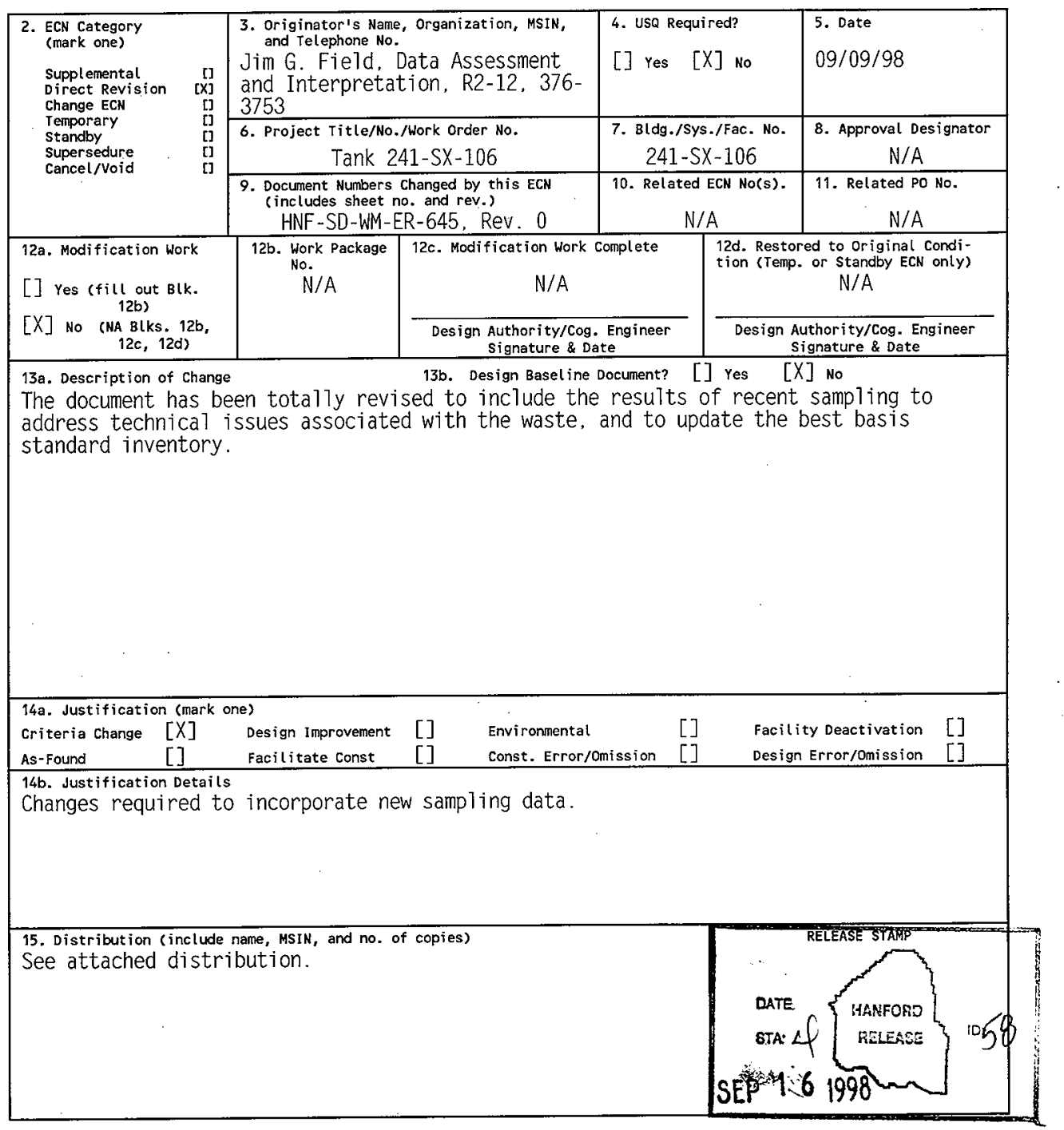




\begin{tabular}{l|llllll}
\hline $\begin{array}{l}\text { 16. Design } \\
\text { Verification } \\
\text { Required }\end{array}$ & \multicolumn{3}{|c}{ 17. Cost Impact } \\
ENGI INEERING & \multicolumn{3}{c}{ CONSTRUCTION } \\
{[] Yes } & Additional & {[]} & $\$$ & Additional & {[]} & $\$$ \\
{$[X]$ No } & Savings & {[]} & $\$$ & Savings & {[]} & $\$$
\end{tabular}

18. Schedule Impact (days)

19. Change Impact Review: Indicate the related documents (other than the engineering documents identified on side 1 ) that will be affected by the change described in Block 13 . Enter the affected document number in Block 20.

$$
\text { SDD/DD }
$$

Fünctional Design Criteria

Operating Specification

Criticality Specification

Conceptual Design Report

[]

[]

Equipment Spec.

Const. Spec.

Procurement Spec.

Vendor Information

OM Manual

[]

[]

[]

[]

[]

[]

FSAR/SAR

Safety Equipment List

Radiation Work Permit

Environmental Impact Statement

Environmental Report

Environmental Permit
Seismic/Stress Analysis

Stress/Design Report

Interface Control Drawing

Calibration Procedure

Installation Procedure

Maintenance Procedure

Engineering Procedure

Operating Instruction

Operating Procedure

Operational Safety Requirement

IEFD Drawing

Cell Arrangement Drawing

Essential Material Specification

Fac. Proc. Samp. Schedule

Inspection Plan

Inventory Adjustment Request
[]

[]

[]

[]

[]

[]

[]

[]

[]

[]

[]

[]

[]

[]

[]
Improvement

Delay
[]

[]

20. Other Affected Documents: (NOTE: Documents listed below will not be revised by this ECN.) Signatures below indicate that the signing organization has been notified of other affected documents listed below. Document Number/Revision

Document Number/Revision

Document Number Revision

N/A

21. Approvals

Design Authority

signature

Date

cog. Eng. J.G. Field $Q$ \& Fild

Cog. Mgr. K.M. Hall stachlew, $\mathrm{h}$ thee

QA

Safety

Environ.

other J.w. Cammann geV Cammamn

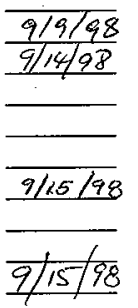

Design Agent

signature

Date

PE

QA

Safety

Design

Environ.

other

DEPARTMENT OF EMERGY

R.J. Cast

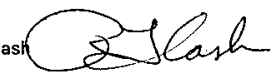

J.G. Kristofzski nWKul fo JGK

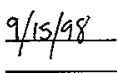

Signature or a Control Number that

tracks the Approval Signature

ADDITIONAL 


\section{Tank Characterization Report for Single-Shell Tank 241-SX-106}

Jim G. Field

Lockheed Martin Hanford Corp., Richland, WA 99352

U.S. Department of Energy Contract DE-AC06-87RL10930

EDT/ECN: $\quad$ ECN-643829

Org Code: 74620

B\&R Code: EW 3120074
UC: 2070

Charge Code: N4G4C

Total Pages:

Key Words: Waste Characterization, Single-Shell Tank, SST, Tank 241-SX106. Tank SX-106, SX-106, SX Farm, Tank Characterization Report, TCR, Waste Inventory, TPA Milestone M-44

Abstract: This document summarizes the information on the historical uses, present status, and the sampling and analysis results of waste stored in Tank 241-SX-106. This report supports the requirements of the Trj-Party Agreement Mi lestone M-44-15B.

TRADEMARK DISCLAIMER. Reference herein to any specific comercial product, process, or service by trade name, trademark, manufacturer, or otherwise, does not necessarily constitute or imply its endorsement, recommendation, or favoring by the United States Government or any agency thereof or its contractors or subcontractors.

Printed in the United States of America. To obtain copies of this document, contact: WHC/8CS Document Control Services, P.0. Box 1970, Mailstop H6-08, Richland WA 99352, Phone (509) 372-2420; Fax (509) 376-4989.
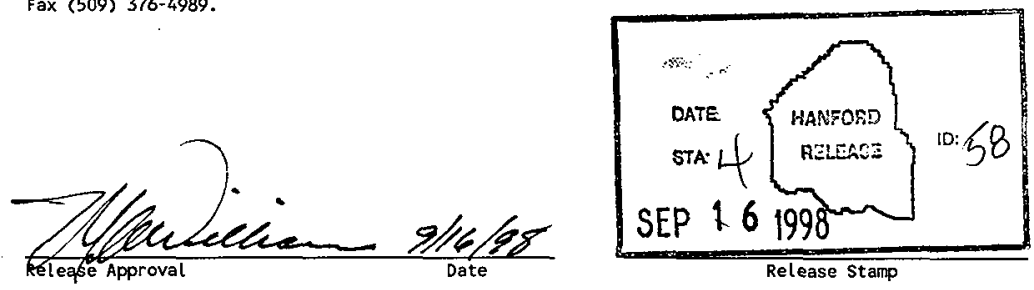

Release stamp

\section{Approved for Public Release}




\section{RECORD OF REVISION}

(2) Title

Tank Characterization Report for Single-Shell Tank 241-SX-106

CHANGE CONTROL RECORD

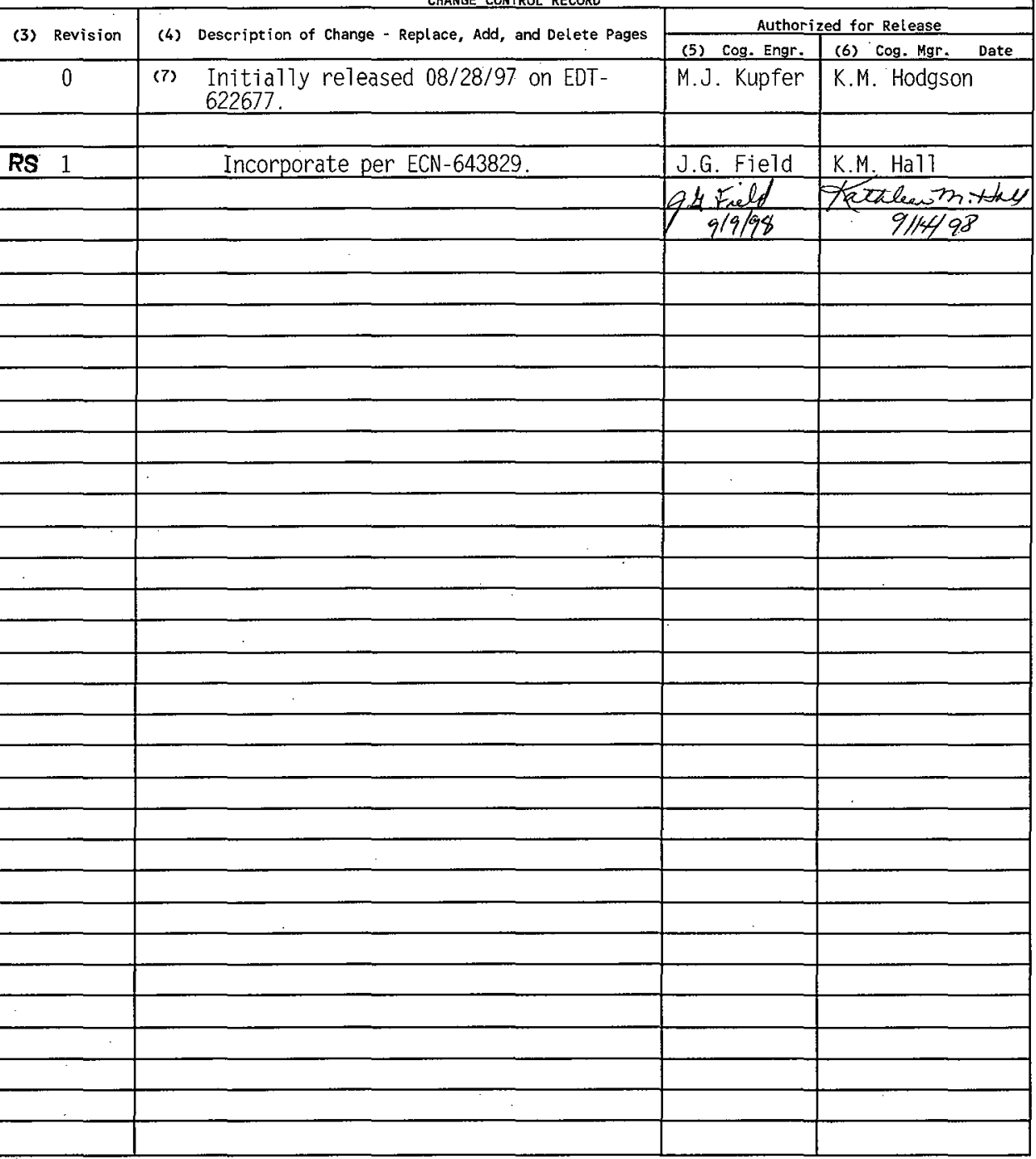




\section{Tank Characterization Report for Single-Shell Tank 241-SX-106}

C. J. Lindquist

Los Alamos Technical Associates

S. R. Wilmarth

Lockheed Martin Hanford Corp.

L. J. Fergestrom

Technical Resources international, Inc.

M. D. Crippen

COGEMA Engineering Corporation

Date Published

September 1998

Prepared for the U.S. Department of Energy

Assistant Secretary for Environmental Management

TUUOR DANIEL HANFOR, INC.

P.O. Box 1000

Richland, Washington

Hanford Management and Integration Contractor for the

U.S. Department of Energy under Contract DE-ACO6-96RL13200

Approved for Public Release; Further Dissemination Unlimited 


\section{CONTENTS}

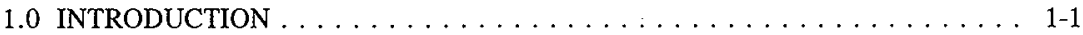

1.1 SCOPE . . . . . . . . . . . . . . . . . . $1-1$

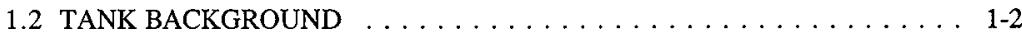

2.0 RESPONSE TO TECHNICAL ISSUES $\ldots \ldots \ldots \ldots \ldots \ldots \ldots \ldots$ 2-1

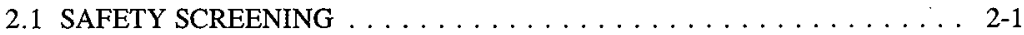

2.1.1 Exothermic Conditions (Energetics) $\ldots \ldots \ldots \ldots \ldots \ldots . \ldots . \ldots 2-1$

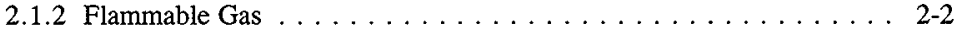

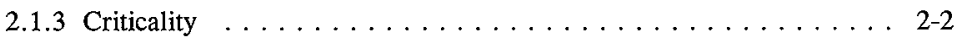

2.2 FLAMMABLE GAS DATA QUALITY OBJECTIVE . . . . . . . . 2-2

2.3 ORGANIC COMPLEXANT . . . . . . . . . . . . . . 2-3

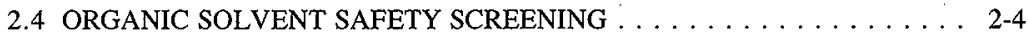

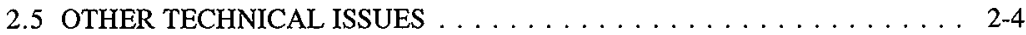

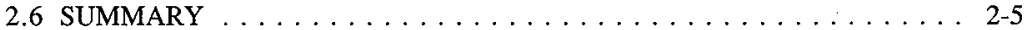

3.0 BEST-BASIS STANDARD INVENTORY ESTIMATE $\ldots \ldots \ldots \ldots \ldots \ldots$. $\ldots \ldots$

4.0 RECOMMENDATIONS $\ldots \ldots \ldots \ldots \ldots \ldots \ldots \ldots \ldots \ldots \ldots$ 4-1

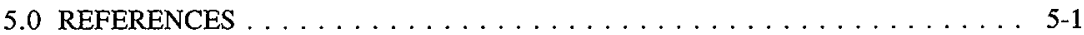

APPENDICES

APPENDIX A: HISTORICAL TANK INFORMATION $\ldots \ldots \ldots \ldots \ldots$ A-1

A1.0 CURRENT TANK STATUS $\ldots \ldots \ldots \ldots \ldots \ldots \ldots \ldots \ldots \ldots$ A-3

A2.0 TANK DESIGN AND BACKGROUND $\ldots \ldots \ldots \ldots \ldots \ldots \ldots$ A-4

A3.0 PROCESS KNOWLEDGE . . . . . . . . . . . . . . . . . A-8

A3.1 WASTE TRANSFER HISTORY . . . . . . . . . . . . A-8

A3.2 HISTORICAL ESTIMATION OF TANK CONTENTS . . . . . . . . . A A-11

A4.0 SURVEILLANCE DATA $\ldots \ldots \ldots \ldots \ldots \ldots \ldots \ldots \ldots \ldots \ldots \ldots$ A-16

A4.1 SURFACE-LEVEL READINGS $\ldots \ldots \ldots \ldots \ldots \ldots \ldots \ldots$ A-16

A4.2 DRY-WELL READINGS $\ldots \ldots \ldots \ldots \ldots \ldots \ldots \ldots$ A-17

A4.3 INTERNAL TANK TEMPERATURES $\ldots \ldots \ldots \ldots \ldots \ldots \ldots$ A-17

A4.4 STANDARD HYDROGEN MONITORING SYSTEM . . . . . . . . . A-17

A4.5 TANK 241-SX-106 PHOTOGRAPHS . . . . . . . . . . . . . . A-17 


\section{CONTENTS (Continued)}

A5.0 APPENDIX A REFERENCES $\ldots \ldots \ldots \ldots \ldots \ldots \ldots \ldots \ldots \ldots$ A-20

APPENDIX B: SAMPLING OF TANK $241-$ SX-106 $\ldots \ldots \ldots \ldots \ldots \ldots$ B-1

B1.0 TANK SAMPLING OVERVIEW $\ldots \ldots \ldots \ldots \ldots \ldots \ldots \ldots$ B-3

B2.0 SAMPLING EVENTS $\ldots \ldots \ldots \ldots \ldots \ldots \ldots \ldots \ldots$ B-4

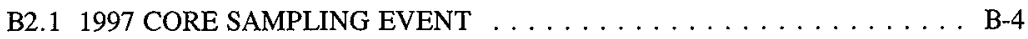

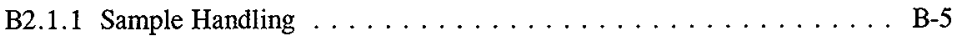

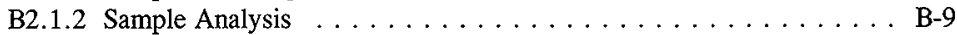

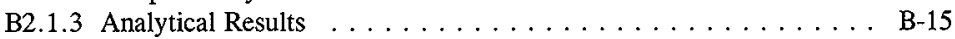

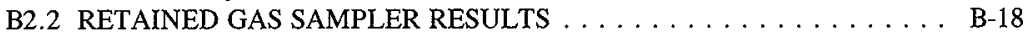

B2.3 VAPOR PHASE MEASUREMENT $\ldots \ldots \ldots \ldots \ldots \ldots \ldots \ldots$ B-20

B2.3.1 Standard Hydrogen Monitoring System Results . . . . . . . . B-22

B2.4 DESCRIPTION OF HISTORICAL SAMPLING EVENTS . . . . . . . . . B B-22

B3.0 ASSESSMENT OF CHARACTERIZATION RESULTS . . . . . . . . . B-121

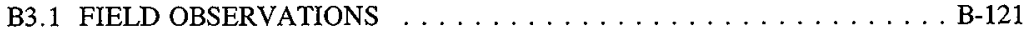

B3.2 QUALITY CONTROL ASSESSMENT . . . . . . . . . . B-121

B3.3 DATA CONSISTENCY CHECKS . . . . . . . . . . . . . B-123

B3.3.1 Comparison of Results from Different Analytical Methods . . . . B-123

B3.3.2 Mass and Charge Balance . . . . . . . . . . . . . B-123

B3.4 MEAN CONCENTRATIONS AND CONFIDENCE INTERVALS . . . B B-127

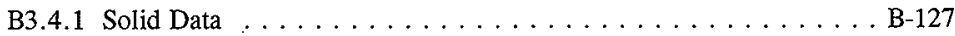

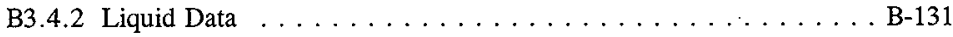

B4.0 APPENDIX B REFERENCES $\ldots \ldots \ldots \ldots \ldots \ldots \ldots \ldots \ldots \ldots$ B-134

APPENDIX C: STATISTICAL ANALYSIS FOR ISSUE RESOLUTION $\ldots \ldots \ldots$ C-1

C1.0 STATISTICS FOR THE SAFETY SCREENING

DATA QUALITY OBJECTIVE . . . . . . . . . . . . . . . . . C-3

C1.1 TOTAL ALPHA ACTIVITY STATISTICAL ANALYSIS . . . . . . . C C-3

C1.2 DIFFERENTIAL SCANNING CALORIMETRY STATISTICAL

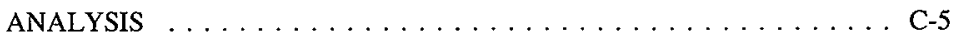

C2.0 APPENDIX C REFERENCES $\ldots \ldots \ldots \ldots \ldots \ldots \ldots \ldots \ldots \ldots$ C-6

APPENDIX D: EVALUATION TO ESTABLISH THE BEST-BASIS

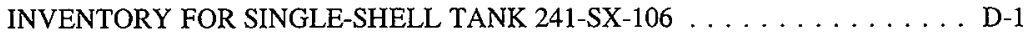




\section{CONTENTS (Continued)}

D1.0 CHEMICAL INFORMATION SOURCES $\ldots \ldots \ldots \ldots \ldots \ldots \ldots$ D-3

D2.0 COMPARISON OF COMPONENT INVENTORY VALUES $\ldots \ldots \ldots \ldots \ldots$ D-3

D3.0 COMPONENT INVENTORY EVALUATION $\ldots \ldots \ldots \ldots \ldots \ldots \ldots \ldots$ D-6

D3.1 WASTE HISTORY . . . . . . . . . . . . . . . . . D 6 .

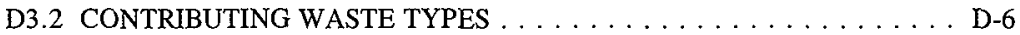

D3.3 EVALUATION OF TANK WASTE VOLUME $\ldots \ldots \ldots \ldots \ldots \ldots$ D-6

D3.4 ASSUMPTIONS USED . . . . . . . . . . . . . . . . D-7

D3.5 BASIS FOR CALCULATIONS USED IN THIS ENGINEERING

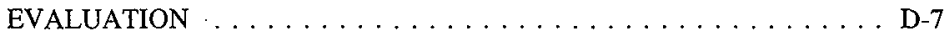

D3.5.1 Supernatant Mixing Model S1 Saltcake $\ldots \ldots \ldots \ldots \ldots \ldots$ D-8

D3.5.2 Supernatant Mixing Model S2 Saltcake $\ldots \ldots \ldots \ldots \ldots \ldots$ D-9

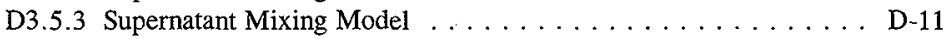

D3.6 ESTIMATED COMPONENT INVENTORIES $\ldots \ldots \ldots \ldots \ldots \ldots$ D-13

D4.0 DEFINE THE BEST-BASIS AND ESTABLISH COMPONENT

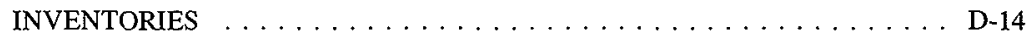

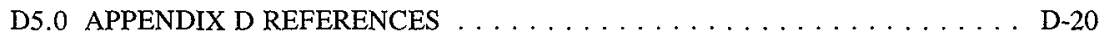

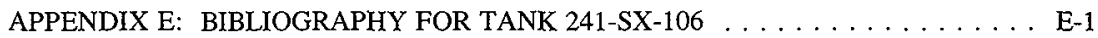




\section{LIST OF FIGURES}

A2-1 Riser Configuration for Tank $241-S X-106 \ldots \ldots \ldots \ldots \ldots$ A-6

A2-2 Tank 241-SX-106 Cross Section and Schematic $\ldots \ldots \ldots \ldots \ldots \ldots \ldots$ A-7

A3-1 Tank Layer Model $\ldots \ldots \ldots \ldots \ldots \ldots \ldots \ldots \ldots \ldots \ldots$ A-12

A4-1 Tank 241-SX-106 Level History $\ldots \ldots \ldots \ldots \ldots \ldots \ldots \ldots \ldots$ A-18

A4-2 Tank 241-SX-106 High Temperature Plot . . . . . . . . . . . . . A-19

\section{LIST OF TABLES}

1-1 Summary of Recent Sampling . . . . . . . . . . . . . . 1-2

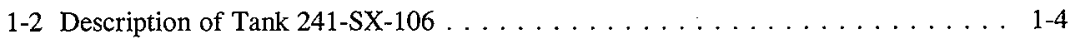

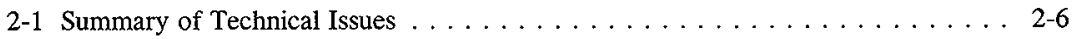

3-1 Best-Basis Inventory Estimates for Nonradioactive Components in Tank $241-$ SX-106 . . . . . . . . . . . . . . . . . . 3-2

3-2 Best-Basis Inventory Estimates for Radioactive Components in Tank 241-SX-106 Decayed to January $1,1994 \ldots \ldots \ldots \ldots$. . . . . . . . . . . . . . . . . .

4-1 Acceptance of Tank 241-SX-106 Sampling and Analysis . . . . . . . . . 4-2

4-2 Acceptance of Evaluation of Characterization Data and Information for Tank 241-SX-106

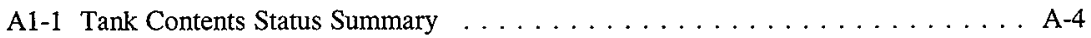

A2-1 Tank $241-$ SX-106 Risers $\ldots \ldots \ldots \ldots \ldots \ldots \ldots \ldots \ldots$ A-5

A3-1 Tank 241-SX-106 Major Transfers $\ldots \ldots \ldots \ldots \ldots \ldots \ldots \ldots$ A-9 . . . . . . . . .

A3-2 Historical Tank Inventory Estimate $\ldots \ldots \ldots \ldots \ldots \ldots \ldots \ldots$ A-13

B2-1 Integrated Data Quality Objective Requirements for Tank 241-SX-106 . . . . . B-5 


\section{LIST OF TABLES (Continued)}

B2-2 Tank 241-SX-106 Subsampling Scheme and Sample Description . . . . . . . . B-6

B2-3 Analytical Procedures $\ldots \ldots \ldots \ldots \ldots \ldots \ldots \ldots \ldots \ldots$ B-10

B2-4 Tank 241-SX-106 Sample Analysis Summary . . . . . . . . . . . B-10

B2-5 Analytical Tables $\ldots \ldots \ldots \ldots \ldots \ldots \ldots \ldots \ldots \ldots \ldots \ldots$

B2-6 Sample and Overall Average Compositions of Retained Gas with Gas

Contamination Correction $\ldots \ldots \ldots \ldots \ldots \ldots \ldots \ldots \ldots \ldots$

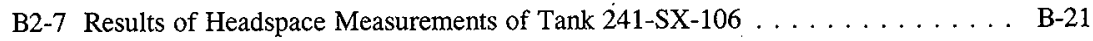

B2-8 Results of March 24, 1995, Headspace Vapor Sample Analysis . . . . . . B B-21

B2-9 Tank 241-SX-106 Analytical Results: Aluminum (ICP) $\ldots \ldots \ldots \ldots \ldots$ B-23

B2-10 Tank 241-SX-106 Analytical Results: Antimony (ICP) . . . . . . . . . B-25

B2-11 Tank 241-SX-106 Analytical Results: Arsenic (ICP) $\ldots \ldots \ldots \ldots \ldots \ldots$ B-27

B2-12 Tank 241-SX-106 Analytical Results: Barium (ICP) . . . . . . . . . . . B-29

B2-13 Tank 241-SX-106 Analytical Results: Beryllium (ICP) $\ldots \ldots \ldots \ldots \ldots$ B-31

B2-14 Tank 241-SX-106 Analytical Results: Bismuth (ICP) . . . . . . . . . B B-33

B2-15 Tank 241-SX-106 Analytical Results: Boron (ICP) $\ldots \ldots \ldots \ldots \ldots \ldots$ B-35

B2-16 Tank 241-SX-106 Analytical Results: Cadmium (ICP) $\ldots \ldots \ldots \ldots \ldots$ B-37

B2-17 Tank 241-SX-106 Analytical Results: Calcium (ICP) . . . . . . . . . . B B-39

B2-18 Tank 241-SX-106 Analytical Results: Cerium (ICP) . . . . . . . . . B B-41

B2-19 Tank 241-SX-106 Analytical Results: Chromium (ICP) . . . . . . . . . B-43

B2-20 Tank 241-SX-106 Analytical Results: Cobalt (ICP) . . . . . . . . . B-45

B2-21 Tank 241-SX-106 Analytical Results: Copper (ICP) . . . . . . . . . . . B-47 


\section{LIST OF TABLES (Continued)}

B2-22 Tank 241-SX-106 Analytical Results: Iron (ICP) . . . . . . . . . . . . B-49

B2-23 Tank 241-SX-106 Analytical Results: Lanthanum (ICP) $\ldots \ldots \ldots \ldots$. . . . F1

B2-24 Tank 241-SX-106 Analytical Results: Lead (ICP) . . . . . . . . . . . B-53

B2-25 Tank 241-SX-106 Analytical Results: Lithium (ICP) . . . . . . . . . B B-55

B2-26 Tank 241-SX-106 Analytical Results: Magnesium (ICP) . . . . . . . . . . B-57

B2-27 Tank 241-SX-106 Analytical Results: Manganese (ICP) . . . . . . . . . B-59

B2-28 Tank 241-SX-106 Analytical Results: Molybdenum (ICP) $\ldots \ldots \ldots \ldots$. . B-61

B2-29 Tank 241-SX-106 Analytical Results: Neodymium (ICP) . . . . . . . . . . B-63

B2-30 Tank 241-SX-106 Analytical Results: Nickel (ICP) . . . . . . . . . . . B-65

B2-31 Tank 241-SX-106 Analytical Results: Phosphorus (ICP) . . . . . . . . . B-66

B2-32 Tank 241-SX-106 Analytical Results: Potassium (ICP) $\ldots \ldots \ldots \ldots \ldots$ B-68

B2-33 Tank 241-SX-106 Analytical Results: Samarium (ICP) . . . . . . . . . . B-69

B2-34 Tank 241-SX-106 Analytical Results: Selenium (ICP) $\ldots \ldots \ldots \ldots$. . . . . . .

B2-35 Tank 241-SX-106 Analytical Results: Silicon (ICP) $\ldots \ldots \ldots \ldots \ldots$. . . . . . .

B2-36 Tank 241-SX-106 Analytical Results: Silver (ICP) $\ldots \ldots \ldots \ldots \ldots \ldots$. . . . . . . .

B2-37 Tank 241-SX-106 Analytical Results: Sodium (ICP) . . . . . . . . . . B-77

B2-38 Tank 241-SX-106 Analytical Results: Strontium (ICP) . . . . . . . . B-79

B2-39 Tank 241-SX-106 Analytical Results: Sulfur (ICP) $\ldots \ldots \ldots \ldots \ldots \ldots$ B-81

B2-40 Tank 241-SX-106 Analytical Results: Thallium (ICP) . . . . . . . . . B B-83

B2-41 Tank 241-SX-106 Analytical Results: Titanium (ICP) . . . . . . . . . B B-85

B2-42 Tank 241-SX-106 Analytical Results: Total Uranium (ICP) . . . . . . . . . B-87 


\section{LIST OF TABLES (Continued)}

B2-43 Tank 241-SX-106 Analytical Results: Vanadium (ICP) . . . . . . . . . . B B-89

B2-44 Tank 241-SX-106 Analytical Results: Zinc (ICP) $\ldots \ldots \ldots \ldots \ldots \ldots$. . . . . .

B2-45 Tank 241-SX-106 Analytical Results: Zirconium (ICP) . . . . . . . . B-93

B2-46 Tank 241-SX-106 Analytical Results: Bromide (IC) . . . . . . . . . . B B-95

B2-47 Tank 241-SX-106 Analytical Results: Chloride (IC) $\ldots \ldots \ldots \ldots \ldots \ldots$ B-97

B2-48 Tank 241-SX-106 Analytical Results: Fluoride (IC) . . . . . . . . . . . B-99

B2-49 Tank 241-SX-106 Analytical Results: Nitrate (IC) . . . . . . . . . . B-101

B2-50 Tank 241-SX-106 Analytical Results: Nitrite (IC) . . . . . . . . . B-103

B2-51 Tank 241-SX-106 Analytical Results: Phosphate (IC) . . . . . . . . . . . . B-105

B2-52 Tank 241-SX-106 Analytical Results: Sulfate (IC) $\ldots \ldots \ldots \ldots \ldots \ldots$. . . . . . .

B2-53 Tank 241-SX-106 Analytical Results: Oxalate (IC) $\ldots \ldots \ldots \ldots \ldots \ldots$ B-109

B2-54 Tank 241-SX-106 Analytical Results: Total Inorganic Carbon . . . . . . . B-111

B2-55 Tank 241-SX-106 Analytical Results: Total Organic Carbon . . . . . . . . B-113

B2-56 Tank 241-SX-106 Analytical Results: Total Organic Carbon . . . . . . . B B-114

B2-57 Tank 241-SX-106 Analytical Results: Total Alpha . . . . . . . . . . . B-115

B2-58 Tank 241-SX-106 Analytical Results: Exotherms - Calculated Dry

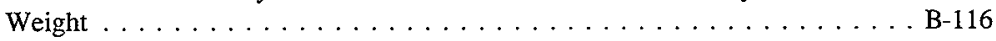

B2-59 Tank 241-SX-106 Analytical Results: Exotherm - Transition $1 \ldots \ldots$. . . B-116

B2-60 Tank 241-SX-106 Analytical Results: Percent Water . . . . . . . . . . B B-117

B2-61 Tank 241-SX-106 Analytical Results: Bulk Density . . . . . . . . . . . . B-119

B2-62 Tank 241-SX-106 Analytical Results: Specific Gravity . . . . . . . . . . B-120 


\section{LIST OF TABLES (Continued)}

B3-1 Sludge Cation Mass and Charge Data $\ldots \ldots \ldots \ldots \ldots \ldots$ B-124

B3-2 Sludge Anion Mass and Charge Data $\ldots \ldots \ldots \ldots \ldots \ldots \ldots \ldots$ B-125

B3-3 Sludge Mass and Charge Balance Totals . . . . . . . . . . . . B-125

B3-4 Supernatant Cation Mass and Charge Data $\ldots \ldots \ldots \ldots \ldots \ldots \ldots$ B-126

B3-5 Supernatant Anion Mass and Charge Data $\ldots \ldots \ldots \ldots \ldots$. . . . . . . . . . . .

B3-6 Supernatant Mass and Charge Balance Totals $\ldots \ldots \ldots \ldots \ldots \ldots \ldots$ B-127

B3-7 Tank 241-SX-106 95 Percent Two-Sided Confidence Interval for the Mean Concentration for Solid Segment Data . . . . . . . . . . . . . . . . . B-129

B3-8 Tank 241-SX-106 95 Percent Two-Sided Confidence Interval for the Mean Concentration for Liquid Subdivision Data . . . . . . . . . . . B-132

C1-1 95 Percent Upper Confidence Limits for Total Alpha Activity . . . . . . . . C-4

C1-2 95 Percent Upper Confidence Limits for Differential Scanning Calorimetry . . . C-5

D2-1 Comparison of Inventory Estimates for Nonradioactive Components in

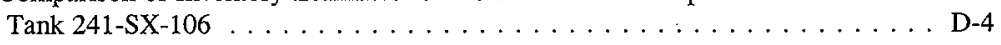

D2-2 Comparison of Inventory Estimates for Selected Radioactive Components in

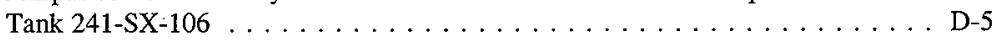

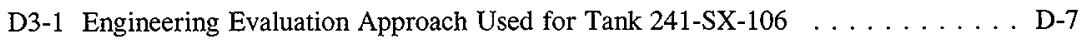

D3-2 Tank 241-SX-106 Waste Type Supernatant Mixing Model S1 Saltcake Concentrations . . . . . . . . . . . . . . . . . D-8

D3-3 Tank 241-SX-106 Waste Type Supernatant Mixing Moḍel S2 Saltcake Concentrations . . . . . . . . . . . . . . . . . D-10

D3-4 Tank 241-SX-106 Waste Type Supernatant Mixing Model Supernatant Concentrations . . . . . . . . . . . . . . . . D-11

D3-5 Comparison of Inventory Estimates for Tank 241-SX-106 $\ldots \ldots \ldots \ldots$ D-13 


\section{LIST OF TABLES (Continued)}

D4-1 Best-Basis Inventory Estimates for Nonradioactive Components in

Tank 241-SX-106 . . . . . . . . . . . . . . . . . . . . . D-15

D4-2 Best-Basis Inventory Estimates for Radioactive Components in

Tank 241-SX-106 Decayed to January $1,1994 \ldots \ldots \ldots \ldots \ldots \ldots \ldots$ D-17 


\section{LIST OF TERMS}

\begin{tabular}{|c|c|}
\hline $\mathrm{AES}$ & atomic emission spectrocopy \\
\hline ANOVA & analysis of variance \\
\hline BPE & barometric pressure effect \\
\hline Btu/hr & British thermal units per hour \\
\hline $\mathrm{Ci}$ & curie \\
\hline $\mathrm{Ci} / \mathrm{L}$ & curies per liter \\
\hline CI & confidence interval \\
\hline $\mathrm{cm}$ & centimeter \\
\hline$d f$ & degrees of freedom \\
\hline DQO & data quality objective \\
\hline DSC & differential scanning calorimetry \\
\hline $\mathrm{ft}$ & feet \\
\hline $\mathrm{ft}^{3}$ & cubic feet \\
\hline $\mathrm{g}$ & gram \\
\hline $\mathrm{g} / \mathrm{cm}^{3}$ & grams per cubic centimeter \\
\hline $\mathrm{g} / \mathrm{L}$ & grams per liter \\
\hline $\mathrm{g} / \mathrm{mL}$ & grams per milliliter \\
\hline HDW & Hanford defined waste \\
\hline $\mathrm{IC}$ & ion chromatography \\
\hline ICP & inductively coupled plasma (spectroscopy) \\
\hline in. & inch \\
\hline $\mathrm{J} / \mathrm{g}$ & joules per gram \\
\hline $\mathrm{kg}$ & kilogram \\
\hline kgal & kilogallon \\
\hline $\mathrm{kL}$ & kiloliter \\
\hline $\mathrm{kW}$ & kilowatt \\
\hline LFL & lower flammability limit \\
\hline LL & lower limit \\
\hline $\mathrm{m}$ & meter \\
\hline $\mathrm{m}^{3}$ & cubic meters \\
\hline M & moles per liter \\
\hline mbar & millibars \\
\hline $\mathrm{mg} / \mathrm{L}$ & milligrams per liter \\
\hline $\mathrm{mL}$ & milliliter \\
\hline $\mathrm{mm}$ & millimeter \\
\hline $\mathrm{mol} \%$ & molecular percent \\
\hline MOU & memorandum of understanding \\
\hline $\mathrm{n} / \mathrm{a}$ & not applicable \\
\hline NA & not analyzed \\
\hline N/A & not available \\
\hline $\mathrm{N} / \mathrm{D}$ & not determined \\
\hline
\end{tabular}




\section{LIST OF TERMS (Continued)}

NR

PHMC

ppm

ppmv

REDOX

RGS

RPD

SAP

SHMS

S1-SltCk

S2-SltS1r

SMM

SMMS

SMMS1

SMMS2

TGA

TIC

TLM

TOC

TWRS

UL

W

WSTRS

wt\%

$\%$

${ }^{\circ} \mathrm{C}$

${ }^{\circ} \mathrm{F}$

$\mu \mathrm{Ci} / \mathrm{g}$

$\mu \mathrm{Ci} / \mathrm{mL}$

$\mu \mathrm{eq} / \mathrm{g}$

$\mu \mathrm{g} \mathrm{C} / \mathrm{g}$

$\mu \mathrm{g} \mathrm{C} / \mathrm{mL}$

$\mu \mathrm{g} / \mathrm{g}$

$\mu \mathrm{g} / \mathrm{mL}$

$\mu \mathrm{mol} / \mathrm{L}$ not requested

Project Hanford Management Contractor

parts per million

parts per million by volume

reduction oxidation (facility)

retained gas sampler

relative percent difference

sampling and analysis plan

standard hydrogen monitoring system

242-S Evaporator saltcake generated from 1973 to 1976

242-S Evaporator saltcake generated from 1997 to 1980

supernatant mixing model

SMM 242-S Evaporator saltcake

SMM 242-S Evaporator saltcake generated from 1973 until 1976

SMM 242-S Evaporator saltcake generated from 1977 until 1980

thermogravimetric analysis

total inorganic carbon

tank layer model

total organic carbon

Tank Waste Remediation System

upper limit

watt

Waste Status and Transaction Record Summary

weight percent

percent

degrees Celsius

degrees Fahrenheit

microcuries per gram

microcuries per milliliter

microequivalents per gram

micrograms of carbon per gram

micrograms of carbon per milliliter

micrograms per gram

micrograms per milliliter

micromoles per liter 
HNF-SD-WM-ER-645 Rev. 1

This page intentionally left blank. 


\subsection{INTRODUCTION}

A major function of the Tank Waste Remediation System (TWRS) is to characterize waste in support of waste management and disposal activities at the Hanford Site. Analytical data from sampling and analysis and other available information about a tank are compiled and maintained in a tank characterization report. This report and its appendices serve as the tank characterization report for single-shell tank 241-SX-106.

The objectives of this report are 1) to use characterization data in response to technical issues associated with tank 241-SX-106 waste and 2) to provide a standard characterization of this waste in terms of a best-basis inventory estimate. Section 2.0 summarizes the response to technical issues, Section 3.0 shows the best-basis inventory estimate, Section 4.0 makes recommendations about the safety status of the tank and additional sampling needs. The appendices contain supporting data and information. This report supports the requirements of the Hanford Federal Facility Agreement and Consent Order (Ecology et al. 1997), Milestone M-44-15b, change request M-44-97-03 to "issue characterization deliverables consistent with the Waste Information Requirements Documents developed for 1998."

\subsection{SCOPE}

The characterization information in this report originated from sample analyses and known historical sources. The results of recent sample events will be used to fulfill the requirements of the data quality objectives (DQOs) and memoranda of understanding (MOUs) specified in Brown et al. (1997) for this tank. Other information can be used to support conclusions derived from these results.

Appendix A contains historical information for tank 241-SX-106 including surveillance information, records pertaining to waste transfers and tank operations, and expected tank contents derived from a process knowledge model. Appendix B summarizes recent sampling events (see Table 1-1), sample data obtained before 1989, and sampling results. Appendix C reports the statistical analysis and numerical manipulation of data used in issue resolution. Appendix $D$ contains the evaluation to establish the best basis for the inventory estimate in this tank. Appendix $\mathrm{E}$ is a bibliography that resulted from an in-depth literature search of all known information sources applicable to tank 241-SX-106 and its respective waste types. The reports listed in Appendix E are available in the Lockheed Martin Hanford Corp. Tank Characterization and Safety Resource Center. 
Table 1-1. Summary of Recent Sampling.

\begin{tabular}{|c|c|c|c|c|}
\hline Sarnoletbato & Prase & 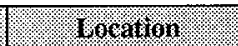 & Sesnientanion & 1) 8 R Recovely \\
\hline $\begin{array}{l}\text { Vapor sample } \\
(3 / 24 / 95)\end{array}$ & Gas & $\begin{array}{l}\text { Tank headspace, } \\
\text { riser } 14,6.7 \mathrm{~m} \\
(22 \mathrm{ft}) \text { below top of } \\
\text { riser }\end{array}$ & $n / a$ & $\mathrm{n} / \mathrm{a}$ \\
\hline $\begin{array}{l}\text { Combustible gas } \\
\text { test } \\
(10 / 13 / 97)\end{array}$ & Gas & $\begin{array}{l}\text { Tank headspace, } \\
\text { riser } 6,6.1 \mathrm{~m} \\
(20 \mathrm{ft}) \text { below top of } \\
\text { riser }\end{array}$ & $\mathrm{n} / \mathrm{a}$ & $n / a$ \\
\hline $\begin{array}{l}\text { Push core } 223 \\
(10 / 13 / 97 \text { to } \\
10 / 30 / 97)\end{array}$ & Solid/liquid & Riser 6 & $\begin{array}{l}10 \text { segments, } \\
\text { upper half and } \\
\text { lower half }\end{array}$ & $0 \%$ to $100 \%$ \\
\hline $\begin{array}{l}\text { Push core } 224 \\
(12 / 2 / 97 \text { to } \\
12 / 11 / 97)\end{array}$ & Solid/liquid & Riser 3 & $\begin{array}{l}11 \text { segments, } \\
\text { upper half and } \\
\text { lower half }\end{array}$ & $68 \%$ to $100 \%$ \\
\hline
\end{tabular}

Notes:

$$
\begin{aligned}
& \mathrm{n} / \mathrm{a}=\text { not applicable } \\
& \text { 'Dates are in the } \mathrm{mm} / \mathrm{dd} / \mathrm{yy} \text { format. }
\end{aligned}
$$

\subsection{TANK BACKGROUND}

Single-shell tank 241-SX-106 is located in the 200 West Area SX Tank Farm on the Hanford Site. It was constructed in 1953-1954 and is the last tank in a three-tank cascade series. From 1954 to 1963 , the tank received supernatant, condensate waste, and sparge transfers from 241-SX tanks and other miscellaneous sources. In 1963, the tank received waste from the Reduction Oxidation (REDOX) facility. Between 1964 and 1975, the tank received waste from the Hanford Laboratory Operations and Pacific Northwest Laboratory. From 1954 to 1971 , waste from the tank was sent to the S-021 crib.

From 1972 to 1979 , waste was transferred into and out of tank 241-SX-106 in support of 242-S Evaporator operations. In 1980, the tank received a neutralized nitric acid/potassium permanganate $\left(\mathrm{HNO}_{3} / \mathrm{KMnO}_{4}\right)$ solution to neutralize the waste and increase volume reduction. For most of its process history, the tank received flush water from miscellaneous sources (Agnew et al. 1997b). The tank was removed from service and labeled inactive in 1980 and was partially isolated in 1985 . 
Table 1-2 summarizes the description of tank 241-SX-106. The tank has a maximum storage capacity of 3,785 kL (1,000 kgal) and, as of May 31, 1998, contained an estimated 2,037 kL (538 kgal) of noncomplexed waste (Hanlon 1998). The tank is actively ventilated and is on the Watch List (Public Law 101-510) for flammable gas and organics issues. 
Table 1-2. Description of Tank 241-SX-106.

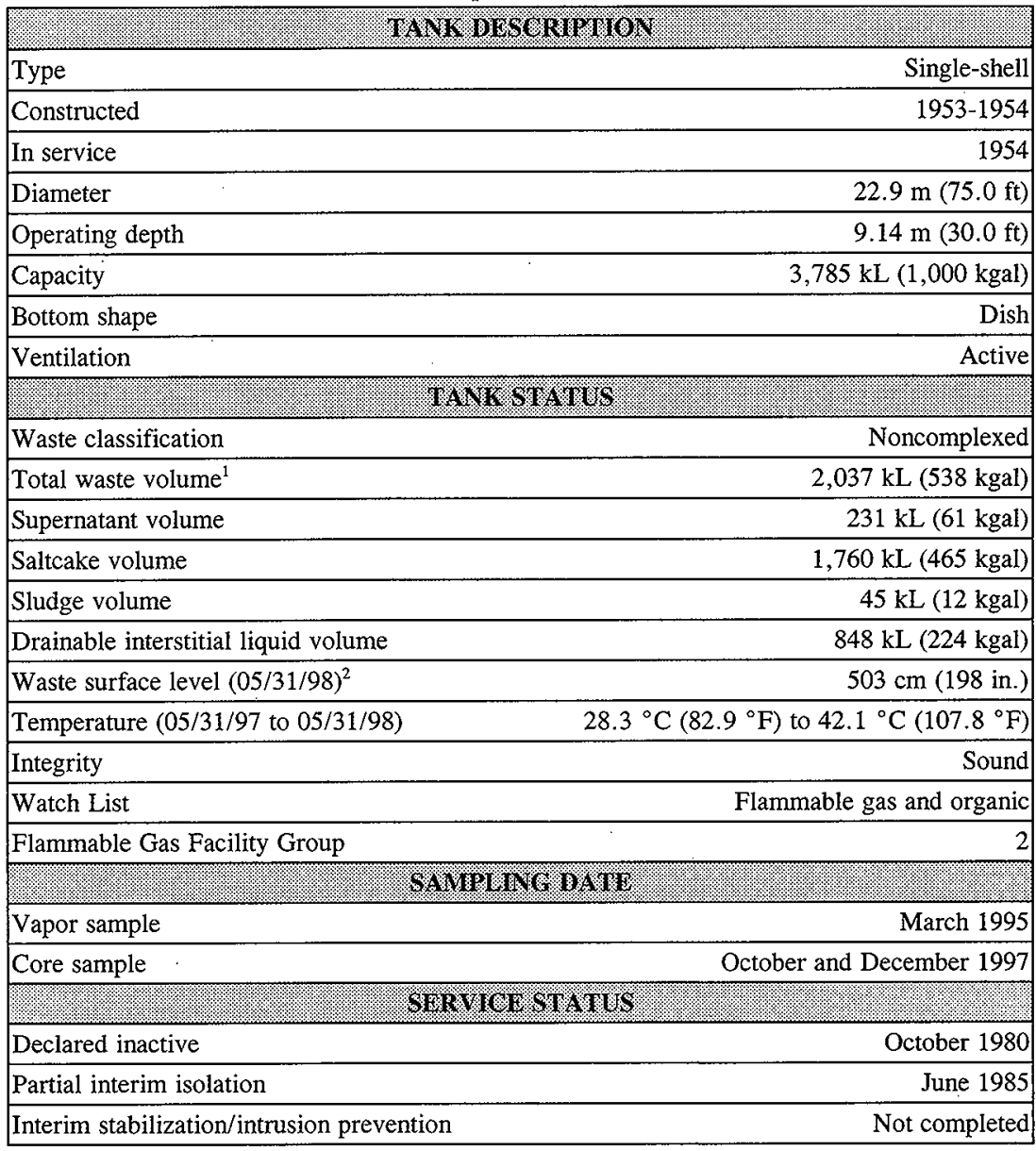

Notes:

${ }^{1}$ Hanlon (1998)

${ }^{2}$ Dates are in the $\mathrm{mm} / \mathrm{dd} / \mathrm{yy}$ format. 


\subsection{RESPONSE TO TECHNICAL ISSUES}

The following technical issues have been identified for tank 241-SX-106 (Brown et al. 1997).

- Safety screening: Does the waste pose or contribute to any recognized potential safety problems?

- Flammable gas: Does a possibility exist for releasing flammable gases into the headspace of the tank or releasing chemical or radioactive materials into the environment?

- Organic complexant: Does the possibility exist for a point source ignition in the waste followed by a propagation of the reaction in the solid/liquid phase of the waste?

- Organic solvent: Does an organic solvent pool exist that may cause a fire or ignition of organic solvents in entrained waste solids?

The sampling and analysis plan (SAP) (Jo 1997) specifies the types of sampling and analysis used to address the above issues. Data from the analysis of push core samples and tank vapor space measurements, along with available historical information, provided the means to respond to the technical issues. Sections 2.1 through 2.5 present the response. Data from the March 1995 vapor sample provided the means to address vapor screening issues. Appendix B contains sample and analysis data for tank 241-SX-106.

\subsection{SAFETY SCREENING}

The data needed to screen the waste in tank $241-\mathrm{SX}-106$ for potential safety problems are documented in Tank Safety Screening Data Quality Objective (Dukelow et al. 1995). These potential safety problems are exothermic conditions in the waste, flammable gases in the waste and/or tank headspace, and criticality conditions in the waste. Each condition is addressed separately below.

\subsubsection{Exothermic Conditions (Energetics)}

The first requirement outlined in the safety screening DQO (Dukelow et al. 1995) is to ensure that there are not sufficient exothermic constituents (organic) in tank 241-SX-106 to pose a safety hazard. Because of this requirement, energetics in tank 241-SX-106 waste were evaluated. The safety screening DQO required that the waste sample profile be tested for energetics every $24 \mathrm{~cm}$ (9.5 in.) to determine whether the energetics exceeded the safety threshold limit. The threshold limit for energetics is $480 \mathrm{~J} / \mathrm{g}$ on a dry weight basis. Results 
obtained using differential scanning calorimetry (DSC) indicated that no sample from tank 241-SX-106 had mean exothermic reactions (on a dry weight basis) exceeding the safety screening DQO limit. The maximum dry weight exotherm observed was $269 \mathrm{~J} / \mathrm{g}$. The maximum upper limit to a 95 percent confidence interval on the mean was $338 \mathrm{~J} / \mathrm{g}$ from core 224 , segment 11 , upper half. Therefore, energetic behavior is not a concern for this tank. Appendix $\mathrm{C}$ contains the method used to calculate confidence limits.

\subsubsection{Flammable Gas}

Headspace measurements were taken before obtaining the October/December 1997 push core samples. No flammable gas was detected in the tank headspace $(0$ percent of the lower flammability limit [LFL]). This is well below the safety screening limit of 25 percent of the LFL. The March 1995 vapor samples also showed a low flammable gas concentration (<98 ppmv). Data for the combustible gas headspace gas tests (sniff tests) and the March 1995 vapor samples are presented in Appendix B.

\subsubsection{Criticality}

The safety screening DQO threshold for criticality, based on the total alpha activity, is $1 \mathrm{~g} / \mathrm{L}$. Because total alpha activity is measured in $\mu \mathrm{Ci} / \mathrm{g}$ instead of $\mathrm{g} / \mathrm{L}$, the $1 \mathrm{~g} / \mathrm{L}$ limit is converted into units of $\mu \mathrm{Ci} / \mathrm{g}$ by assuming that all alpha decay originates from ${ }^{239} \mathrm{Pu}$. The safety threshold limit is $1 \mathrm{~g}{ }^{239} \mathrm{Pu}$ per liter of waste. Assuming that all alpha is from ${ }^{239} \mathrm{Pu}$ and using the maximum solids density of $1.79 \mathrm{~g} / \mathrm{mL}$, this limit corresponds to $34.4 \mu \mathrm{Ci} / \mathrm{g}$ of total alpha activity for solids. The maximum total alpha activity result was $1.26 \mu \mathrm{Ci} / \mathrm{g}$ (core 224 , segment 9 , lower half). The maximum upper limit to a 95 percent confidence interval on the mean was $1.32 \mu \mathrm{Ci} / \mathrm{g}$ (core 224 , segment 9 , lower half), indicating that the potential for a criticality event is extremely low. Therefore, criticality is not a concern for this tank. Appendix $\mathrm{C}$ contains the method used to calculate confidence limits.

\subsection{FLAMMABLE GAS DATA QUALITY OBJECTIVE}

The requirements to support the flammable gas issue are documented in the Data Quality Objective to Support Resolution of the Flammable Gas Safety Issue (Bauer and Jackson 1998). This DQO has been extended to apply to all tanks. Analyses and evaluations will change according to program needs until this issue is resolved. The unreviewed safety question for flammable gas safety issues is expected to be closed in fiscal year 1998, and final resolution of the flammable gas safety issue is expected to be completed by September 30, 2001 (Johnson 1997). These dates are consistent with Milestones M-40-09 and M-40-00 (Ecology et al. 1997) to close out the unreviewed safety question for Watch List tanks and to resolve all flammable gas safety issues for high priority tanks. 
Retained gas sampler (RGS) samples were taken and analyzed to address flammable gas issues for tank 241-SX-106 (Bauer and Jackson 1998). No specific notification limits or "acceptance levels" have been determined to meet this DQO. The results of RGS testing are reported in Mahoney et al. (1998) and summarized in Appendix B of this document.

An increase of approximately $46 \mathrm{~cm}$ (18 in.) has been observed in the tank surface-level measurements since 1981. This increase is attributed to the retained gases in the tank. Observations from the recent core sample indicate the thickness of the top layer of liquid is between four and five segments at risers 6 and 3. Most of the material is salt or salt slurry, though sludge or sludge/salt slurry is present in the range of segments 6 through 8 of both risers.

Retained gas sampler samples were requested from riser 6 , segments 6,9 , and 11 ; and riser 3 , segments $2,4,7$, and 10 . During the retrieval of segment 11 from riser 6 , the grapple cable broke requiring the drill string and sampler to be removed manually. The x-rays of the sampler indicated that it contained lithium bromide solution and air with no sample material present.

Retained gas sampler sampling showed that the insoluble retained gases in tank 241-SX-106 had an average composition of $19 \mathrm{~mol} \%$ nitrogen, $47 \mathrm{~mol} \%$ hydrogen, $22 \mathrm{~mol} \%$ nitrous oxide, and $11 \mathrm{~mol} \%$ ammonia, with minor components including methane and other hydrocarbons. The measured ammonia levels were unusually high, falling between $30,000 \pm 13,000$ and $130,000 \pm 120,000 \mu \mathrm{mol} / \mathrm{L}$ of waste $\left(0.35\right.$ weight percent $\mathrm{NH}_{3}$ in the liquid). The RGS samples retained void fractions between 0.095 and 0.37 , with much of the high-solids layer (three samples) showing gas volumes fractions $<0.30$. The gas inventory, based on the RGS data, is $360 \pm 180 \mathrm{~m}^{3}$.

Tank 241-SX-106 is equipped with a standard hydrogen monitoring system (SHMS) for the collection of vapor-phase data that support resolution of flammable gas issues. The SHMS vapor data are posted to the tank characterization database (LMHC 1998).

\subsection{ORGANIC COMPLEXANT}

The data required to support the issue of organic complexants are documented in Memorandum of Understanding for the Organic Complexant Safety Issue Data Requirements (Schreiber 1997). Energetics by DSC, moisture, and total organic carbon (TOC) analyses were conducted to address the organic complexant issue.

Several exotherms were observed but did not exceed the limit of $480 \mathrm{~J} / \mathrm{g}$ (dry weight). The TOC results for the persulfate oxidation analysis ranged from 0.18 to 1.13 percent dry weight. Furnace oxidation TOC analysis was required for those samples for which the TOC by persulfate did not account for at least 75 percent of the exothermic energy. This occurred in one sample (core 224 , segment 11 , upper half). Statistical analysis of the TOC measurements 
indicates that there is more than 95 percent confidence that 95 percent of the waste is below 4.5 weight percent TOC on a dry weight basis (Meacham et al. 1998). Consequently, the tank waste has an acceptably low probability of propagation and is classified as "Safe" for this issue.

\subsection{ORGANIC SOLVENT SAFETY SCREENING}

The data required to support the organic solvent safety screening issues are documented in the Data Quality Objective to Support Resolution of the Organic Solvent Safety Issue (Meacham et al. 1997). The DQO requires tank headspace samples be analyzed for total nonmethane organic compounds to determine whether an organic extractant pool exists in the tank. The purpose of this assessment is to ensure that an organic solvent pool fire or ignition of organic solvents cannot occur.

Specific analyses for total nonmethane organic hydrocarbon were not conducted in this tank (Huckaby and Bratzel 1995). The size of an organic extractant pool can be determined by the organics program, based on the analyses that were conducted for the March 1995 vapor sampling and on the tank headspace temperature and ventilation rate. However, the organic program has determined that even if an organic solvent pool does exist, the consequence of a fire or ignition of organic solvents is below risk evaluation guidelines for all of the tanks (Brown et al. 1998). Consequently, additional vapor analyses are not required for this tank. The organic solvent issue is expected to be closed for all tanks in fiscal year 1998.

\subsection{OTHER TECHNICAL ISSUES}

Vapor samples were taken in March 1995 to address the Data Quality Objectives for Tank Hazardous Vapor Safety Screening (Osborne and Buckley 1995). However, this is no longer an issue because headspace vapor (sniff) tests are required for the safety screening DQO (Dukelow et al. 1995), and the toxicity issue was closed for all tanks (Hewitt 1996). Vapor sample results are discussed in Appendix B.

A factor in assessing tank safety is the heat generation and temperature of the waste. Heat is generated in the tanks from radioactive decay. An estimate of the tank heat load based on the 1997 core sample event was not possible because radionuclide analyses were not required. However, the heat load estimate based on the tank process history was $4,310 \mathrm{~W}$ $(14,700 \mathrm{Btu} / \mathrm{hr}$ ) (Agnew et al. 1997a). The heat load estimate based on the tank headspace temperature was $3,180 \mathrm{~W}(10,840 \mathrm{Btu} / \mathrm{hr}$ ) (Kummerer 1995). Both of these estimates are quite low and are well below the limit of $11,700 \mathrm{~W}(40,000 \mathrm{Btu} / \mathrm{hr})$ that separates high- and low-heat-load tanks (Smith 1986). 


\subsection{SUMMARY}

The results of all analyses performed to address potential safety issues showed that primary analyte(s) did not exceed safety decision threshold limits. All requirements for the safety screening and organic complexant issue were met.

Retained gas sampler measurements showed a high volume of retained gases in the samples analyzed. The average composition is $47 \mathrm{~mol} \%$ hydrogen, $22 \mathrm{~mol} \%$ nitrous oxide, $19 \mathrm{~mol} \%$ nitrogen, and $11 \mathrm{~mol} \%$ ammonia, with minor components including methane and other hydrocarbons. The gas inventory, based on the RGS data, is $360 \pm 180 \mathrm{~m}^{3}$. The gas inventory predicted by the barometric pressure effect method is $190 \pm 30 \mathrm{~m}^{3}$. The difference in these gas inventory estimates may be caused by localized high-gas regions that do not extend over the entire tank.

Vapor samples taken in March 1995 met the requirements of the organic solvent safety screening DQO. Sample results are summarized in Table 2-1.

Table 2-1. Summary of Technical Issues. (2 sheets)

\begin{tabular}{|c|c|c|}
\hline Issue & (2.) Sub-issue & Result \\
\hline \multirow[t]{3}{*}{$\begin{array}{l}\text { Safety } \\
\text { screening }\end{array}$} & Energetics & $\begin{array}{l}\text { All exotherms were } \leq 269 \mathrm{~J} / \mathrm{g} \text {, far below the } \\
\text { upper limit of } 480 \mathrm{~J} / \mathrm{g} \text {. }\end{array}$ \\
\hline & Flammable gas & $\begin{array}{l}\text { Vapor measurement was reported as } \\
0 \text { percent of LFL (combustible gas meter). }\end{array}$ \\
\hline & Criticality & $\begin{array}{l}\text { All analyses were less than } 2 \mu \mathrm{Ci} / \mathrm{g} \text {, well } \\
\text { below the total alpha limit of } 34.4 \mu \mathrm{Ci} / \mathrm{g} \text {. }\end{array}$ \\
\hline Flammable gas & $\begin{array}{l}\text { Mechanisms for generation, } \\
\text { retention, and release } \\
\text { Waste models }\end{array}$ & $\begin{array}{l}28 \% \text { of the solid waste volume consisted of } \\
\text { retained gases }\left(190 \pm 30 \mathrm{~m}^{3}\right) \text { with } 47 \mathrm{~mol} \% \\
\text { hydrogen content. Waste contained high } \\
\text { ammonia concentration. Preliminary } \\
\text { assessments of flammable gas generation, } \\
\text { retention, and release mechanisms and } \\
\text { results of waste behavior modeling are } \\
\text { reported in Mahoney et al. (1998). } \\
\text { Additional evaluations to assess potential } \\
\text { impacts and waste behavior in } \\
\text { tank } 241-S X-106 \text { are in progress. }\end{array}$ \\
\hline
\end{tabular}


Table 2-1. Summary of Technical Issues. (2 sheets)

\begin{tabular}{|l|l|l|}
\hline \multicolumn{1}{|c|}{ ISuee } & \multicolumn{1}{|c|}{ Sib issue } & \multicolumn{1}{c|}{ Resull } \\
\hline $\begin{array}{l}\text { Organic } \\
\text { complexants }\end{array}$ & Safety categorization (safe) & $\begin{array}{l}\text { Low DSC and TOC were reported, with no } \\
\text { visible separable organic layer. }\end{array}$ \\
\hline $\begin{array}{l}\text { Organic } \\
\text { solvents }\end{array}$ & Solvent pool size & $\begin{array}{l}\text { Total nonmethane hydrocarbon was not } \\
\text { measured. }\end{array}$ \\
\hline
\end{tabular}

Note:

${ }^{1}$ This issue is expected to be closed in fiscal year 1998. 


\subsection{BEST-BASIS STANDARD INVENTORY ESTIMATE}

Information about chemical, radiological, and/or physical properties is used to perform safety analyses, engineering evaluations, and risk assessments associated with waste management activities as well as regulatory issues. These activities include overseeing tank farm operations and identifying, monitoring, and resolving safety issues associated with these operations and with the tank wastes. Disposal activities involve designing equipment, processes, and facilities for retrieving wastes and processing them into a form that is suitable for long-term storage/disposal.

Chemical and radiological inventory information are generally derived using three approaches: 1) component inventories are estimated using the results of sample analyses; 2) component inventories are predicted using the Hanford defined waste (HDW) model based on process knowledge and historical information; or 3) a tank-specific process estimate is made based on process flowsheets, reactor fuel data, essential material usage, and other operating data.

An effort is underway to provide waste inventory estimates that will serve as standard characterization source terms for the various waste management activities (Hodgson and LeClair 1996). As part of this effort, an evaluation of chemical information for tank 241-SX-106 was performed, and a best-basis inventory was established. This work, detailed in the following sections, follows the methodology that was established by the standard inventory task. The following information was used in the evaluation:

- Analytical data from the 1997 push-mode core sampling event (Appendix B)

- Inventory estimates generated for this tank from the HDW model (Agnew et al. 1997a).

Based on this engineering assessment, a best-basis inventory was developed for tank 241-SX-106 using the 1997 core sampling analytical data. Where analytical data were not available, the HDW model inventory estimates reported by Agnew et al. (1997a) were used as the best basis for this tank.

Best-basis tank inventory values are derived for 46 key radionuclides (as defined in Section 3.1 of Kupfer et al. 1997), all decayed to a common report date of January 1, 1994. Often, waste sample analyses have only reported ${ }^{90} \mathrm{Sr},{ }^{137} \mathrm{Cs},{ }^{239 / 240} \mathrm{Pu}$, and total uranium, or total beta and total alpha, while other key radionuclides such as ${ }^{60} \mathrm{Co},{ }^{99} \mathrm{Tc},{ }^{129} \mathrm{I},{ }^{154} \mathrm{Eu},{ }^{155} \mathrm{Eu}$, and ${ }^{241} \mathrm{Am}$, have been infrequently reported. Therefore, it has been necessary to derive most of the $46 \mathrm{key}$ radionuclides by computer models. These models estimate radionuclide activity in batches of reactor fuel, account for the split of radionuclides to various separations plant waste streams, and track their movement with tank waste transactions. (These computer models are described in Kupfer et al. 1997, Section 6.1, and in Watrous and Wootan 1997.) 
Model-generated values for radionuclides in any of 177 tanks are reported in the HDW Revision 4 model results (Agnew et al. 1997a). The best-basis value for any one analyte may be either a model result or a sample or engineering assessment-based result, if available.

The best-basis inventory estimate for tank $241-\mathrm{SX}-106$ is presented in Tables 3-1 and 3-2. The mercury inventory was specified in Simpson (1998). The inventory of strontium was calculated from the ${ }^{90} \mathrm{Sr}$ activity. The inventory of ${ }^{90} \mathrm{Sr}$ was based on a weighted average of the template estimates for waste types SMMS1 (supernatant mixing model [SMM] 242-S Evaporator saltcake generated from 1973 until 1976) and SMMS2 (SMM 242-S Evaporator saltcake generated from 1977 until 1980) from Sasaki et al. (1998). The inventory of ${ }^{137} \mathrm{Cs}$ was based on the heat load calculated from the difference between the total heat load estimate of $3,180 \mathrm{~W}(10,840 \mathrm{Btu} / \mathrm{hr})$ provided by Kummerer (1995) and the heat load attributed to ${ }^{90} \mathrm{Sr}$.

The inventory values reported in Tables 3-1 and 3-2 are subject to change. Refer to the Tank Characterization Database for the most current inventory values.

Table 3-1. Best-Basis Inventory Estimates for Nonradioactive Components in Tank 241-SX-106 (Effective May 31, 1998). (2 sheets)

\begin{tabular}{|c|c|c|c|}
\hline (2. & 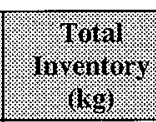 & 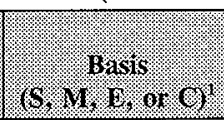 & (c) \\
\hline $\mathrm{Al}$ & 57,500 & $S$ & \\
\hline $\mathrm{Bi}$ & 0 & $\mathrm{E}$ & Not expected based on process history \\
\hline $\mathrm{Ca}$ & 278 & $\mathrm{~S} / \mathrm{E}$ & Solids only \\
\hline $\mathrm{Cl}$ & 21,700 & $S$ & \\
\hline $\mathrm{TIC}$ as $\mathrm{CO}_{3}$ & 62,000 & $S$ & \\
\hline $\mathrm{Cr}$ & 7,140 & $S$ & \\
\hline $\mathrm{F}$ & 1,240 & $S$ & \\
\hline $\mathrm{Fe}$ & 631 & $\mathrm{~S} / \mathrm{E}$ & Solids only \\
\hline $\mathrm{Hg}$ & 0 & $\mathrm{E}$ & Simpson (1998) \\
\hline $\mathrm{K}$ & 5,240 & $S$ & \\
\hline $\mathrm{La}$ & 55 & S/E & Upper bounding limit \\
\hline $\mathrm{Mn}$ & 660 & $\mathrm{~S} / \mathrm{E}$ & Solids only \\
\hline $\mathrm{Na}$ & $5.46 \mathrm{E}+05$ & $S$ & \\
\hline $\mathrm{Ni}$ & 0 & $E$ & Not expected based on process history \\
\hline $\mathrm{NO}_{2}$ & $2.40 \mathrm{E}+05$ & $S$ & \\
\hline
\end{tabular}


Table 3-1. Best-Basis Inventory Estimates for Nonradioactive Components in Tank 241-SX-106 (Effective May 31, 1998). (2 sheets)

\begin{tabular}{|c|c|c|c|}
\hline (6. & $\begin{array}{l}\text { Toral } \\
\text { Inventory } \\
\text { akg? }\end{array}$ & S., M, Basis $01 \cdot()^{\prime}$ & Gomment \\
\hline $\mathrm{NO}_{3}$ & $6.99 \mathrm{E}+05$ & $S$ & \\
\hline $\mathrm{OH}_{\text {TOTAL. }}$ & $1.71 \mathrm{E}+05$ & $\mathrm{C}$ & \\
\hline $\mathrm{Pb}$ & 120 & $S / E$ & Upper bounding limit \\
\hline $\mathrm{PO}_{4}$ & 28,400 & $S$ & \\
\hline $\mathrm{Si}$ & 442 & $S$ & \\
\hline $\mathrm{SO}_{4}$ & 14,400 & $S$ & \\
\hline $\mathrm{Sr}$ & 4.00 & $E$ & $\begin{array}{l}\text { Calculated from }{ }^{90} \mathrm{Sr} \text { assuming that }{ }^{\infty} \mathrm{Sr} \text { is } \\
30 \mathrm{wt} \% \text { of total strontium }\end{array}$ \\
\hline TOC & 9,920 & $S$ & \\
\hline $\mathrm{U}_{\text {TOTAL }}$ & 553 & S/E & Upper bounding limit \\
\hline $\mathrm{Zr}$ & 18 & $\mathrm{~S} / \mathrm{E}$ & Solids only \\
\hline
\end{tabular}

Notes:

TIC $=$ total inorganic carbon

${ }^{1} \mathrm{~S}=$ sample based (see Appendix B), $\mathrm{M}=$ HDW model based (Agnew et al. 1997a), $\mathrm{E}=$ engineering assessment based, and $\mathrm{C}=$ calculated by charge balance; includes oxides as hydroxides, not including $\mathrm{CO}_{3}$, $\mathrm{NO}_{2}, \mathrm{NO}_{3}, \mathrm{PO}_{4}, \mathrm{SO}_{4}$, and $\mathrm{SiO}_{3}$.

Table 3-2. Best-Basis Inventory Estimates for Radioactive Components in Tank 241-SX-106 Decayed to January 1, 1994 (Effective May 31, 1998).

(4 sheets)

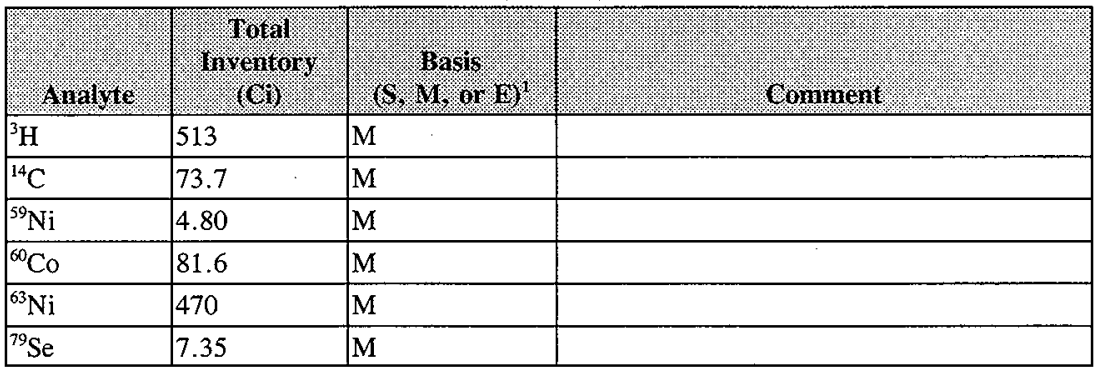


Table 3-2. Best-Basis Inventory Estimates for Radioactive Components in Tank 241-SX-106 Decayed to January 1, 1994 (Effective May 31, 1998).

(4 sheets)

\begin{tabular}{|c|c|c|c|}
\hline malloce & $\begin{array}{l}\text { Total } \\
\text { Inventort) } \\
(\mathrm{Cl}) \text { ) }\end{array}$ & 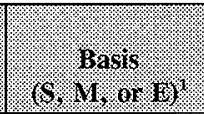 & (1) Ommen: \\
\hline${ }^{90} \mathrm{Sr}$ & $1.70 \mathrm{E}+05$ & E & $\begin{array}{l}\text { Based on the template estimates for waste } \\
\text { types SMMS1 saltcake and SMMS2 saltcake } \\
\text { from Sasaki et al. (1998) }\end{array}$ \\
\hline${ }^{90} \mathrm{Y}$ & $1.70 \mathrm{E}+05$ & E & Based on the ${ }^{90} \mathrm{Sr}$ activity \\
\hline${ }^{93} \mathrm{Zr}$ & 36.1 & $\mathrm{M}$ & \\
\hline${ }^{93 \mathrm{~m}} \mathrm{Nb}$ & 26.2 & $\mathrm{M}$ & \\
\hline${ }^{99} \mathrm{Tc}$ & 525 & $\mathrm{M}$ & \\
\hline${ }^{106} \mathrm{Ru}$ & 0.0145 & $M$ & \\
\hline${ }^{113 \mathrm{~m}} \mathrm{Cd}$ & 189 & M & \\
\hline${ }^{125} \mathrm{Sb}$ & 351 & $\mathrm{M}$ & \\
\hline${ }^{126} \mathrm{Sn}$ & 11.1 & $\mathrm{M}$ & \\
\hline${ }^{129} \mathbf{I}$ & 1.01 & $\mathrm{M}$ & \\
\hline${ }^{134} \mathrm{Cs}$ & 5.57 & $M$ & \\
\hline${ }^{137} \mathrm{Cs}$ & $4.71 \mathrm{E}+05$ & $\mathrm{E}$ & $\begin{array}{l}\text { Based on the heat load calculated from the } \\
\text { difference between the total heat load estimate } \\
\text { from Kummerer (1995) and the heat load } \\
\text { attributed to }{ }^{90} \mathrm{Sr}\end{array}$ \\
\hline${ }^{137 \mathrm{~m}} \mathrm{Ba}$ & $4.45 \mathrm{E}+05$ & $\mathrm{E}$ & Based on 0.946 of the ${ }^{137} \mathrm{Cs}$ activity \\
\hline${ }^{151} \mathrm{Sm}$ & 25,900 & $\mathrm{M}$ & \\
\hline${ }^{152} \mathrm{Eu}$ & 8.49 & $\mathbf{M}$ & \\
\hline${ }^{154} \mathrm{Eu}$ & 1,330 & $\mathrm{M}$ & \\
\hline${ }^{155} \mathrm{Eu}$ & 501 & $\mathbf{M}$ & \\
\hline${ }^{226} \mathrm{Ra}$ & $3.15 \mathrm{E}-04$ & $\mathrm{M}$ & \\
\hline${ }^{227} \mathrm{Ac}$ & 0.00199 & $\mathrm{M}$ & \\
\hline${ }^{228} \mathrm{Ra}$ & 0.307 & $\mathrm{M}$ & \\
\hline${ }^{229} \mathrm{Th}$ & 0.00720 & $\mathrm{M}$ & \\
\hline${ }^{231} \mathrm{~Pa}$ & 0.00913 & $\mathrm{M}$ & \\
\hline${ }^{232} \mathrm{Th}$ & 0.0204 & $\mathrm{M}$ & \\
\hline${ }^{232} \mathrm{U}$ & 0.181 & $\mathrm{~S} / \mathrm{E} / \mathrm{M}$ & $\begin{array}{l}\text { Based on ICP uranium sample result ratioed } \\
\text { to HDW estimates for uranium isotopes }\end{array}$ \\
\hline
\end{tabular}


Table 3-2. Best-Basis Inventory Estimates for Radioactive Components in Tank 241-SX-106 Decayed to January 1, 1994 (Effective May 31, 1998).

(4 sheets)

\begin{tabular}{|c|c|c|c|}
\hline atiduly & 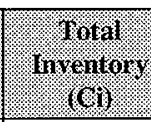 & (8. & (l) \\
\hline${ }^{233} \mathrm{U}$ & 0.693 & $\mathrm{~S} / \mathrm{E} / \mathrm{M}$ & $\begin{array}{l}\text { Based on ICP uranium sample result ratioed } \\
\text { to HDW estimates for uranium isotopes }\end{array}$ \\
\hline${ }^{234} \mathrm{U}$ & 0.203 & S/E/M & $\begin{array}{l}\text { Based on ICP uranium sample result ratioed } \\
\text { to HDW estimates for uranium isotopes }\end{array}$ \\
\hline${ }^{235} \mathrm{U}$ & 0.00823 & $\mathrm{~S} / \mathrm{E} / \mathrm{M}$ & $\begin{array}{l}\text { Based on ICP uranium sample result ratioed } \\
\text { to HDW estimates for uranium isotopes }\end{array}$ \\
\hline${ }^{236} \mathrm{U}$ & 0.00636 & $\mathrm{~S} / \mathrm{E} / \mathrm{M}$ & $\begin{array}{l}\text { Based on ICP uranium sample result ratioed } \\
\text { to HDW estimates for uranium isotopes }\end{array}$ \\
\hline${ }^{237} \mathrm{~Np}$ & 1.92 & $\mathrm{M}$ & . \\
\hline${ }^{238} \mathrm{Pu}$ & 6.45 & $\mathrm{~S} / \mathrm{E} / \mathrm{M}$ & $\begin{array}{l}\text { Based on total alpha activity sample result } \\
\text { ratioed to HDW estimates for alpha isotopes }\end{array}$ \\
\hline${ }^{238} \mathrm{U}$ & 0.185 & S/E/M & $\begin{array}{l}\text { Based on ICP uranium sample result ratioed } \\
\text { to HDW estimates for uranium isotopes }\end{array}$ \\
\hline${ }^{239} \mathrm{Pu}$ & 222 & $\mathrm{~S} / \mathrm{E} / \mathrm{M}$ & $\begin{array}{l}\text { Based on total alpha activity sample result } \\
\text { ratioed to HDW estimates for alpha isotopes }\end{array}$ \\
\hline${ }^{240} \mathrm{Pu}$ & 37.6 & $\mathrm{~S} / \mathrm{E} / \mathrm{M}$ & $\begin{array}{l}\text { Based on total alpha activity sample result } \\
\text { ratioed to HDW estimates for alpha isotopes }\end{array}$ \\
\hline${ }^{241} \mathrm{Am}$ & 269 & $\mathrm{~S} / \mathrm{E} / \mathrm{M}$ & $\begin{array}{l}\text { Based on total alpha activity sample result } \\
\text { ratioed to HDW estimates for alpha isotopes }\end{array}$ \\
\hline${ }^{241} \mathrm{Pu}$ & 436 & $\mathrm{~S} / \mathrm{E} / \mathrm{M}$ & $\begin{array}{l}\text { Based on total alpha activity sample result } \\
\text { ratioed to HDW estimates for alpha isotopes }\end{array}$ \\
\hline${ }^{242} \mathrm{Cm}$ & 0.689 & $\mathrm{~S} / \mathrm{E} / \mathrm{M}$ & $\begin{array}{l}\text { Based on total alpha activity sample result } \\
\text { ratioed to HDW estimates for alpha isotopes }\end{array}$ \\
\hline${ }^{242} \mathrm{Pu}$ & 0.00239 & $\mathrm{~S} / \mathrm{E} / \mathrm{M}$ & $\begin{array}{l}\text { Based on total alpha activity sample result } \\
\text { ratioed to HDW estimates for alpha isotopes }\end{array}$ \\
\hline${ }^{243} \mathrm{Am}$ & 0.00932 & $\mathrm{~S} / \mathrm{E} / \mathrm{M}$ & $\begin{array}{l}\text { Based on total alpha activity sample result } \\
\text { ratioed to HDW estimates for alpha isotopes }\end{array}$ \\
\hline${ }^{243} \mathrm{Cm}$ & 0.0638 & $\mathrm{~S} / \mathrm{E} / \mathrm{M}$ & $\begin{array}{l}\text { Based on total alpha activity sample result } \\
\text { ratioed to HDW estimates for alpha isotopes }\end{array}$ \\
\hline
\end{tabular}


Table 3-2. Best-Basis Inventory Estimates for Radioactive Components in Tank 241-SX-106 Decayed to January 1, 1994 (Effective May 31, 1998).

(4 sheets)

\begin{tabular}{|c|c|c|c|}
\hline Analye & $\begin{array}{l}\text { Total } \\
\text { Inventory } \\
\text { (C) }\end{array}$ & 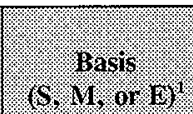 & Connuent \\
\hline${ }^{244} \mathrm{Cm}$ & 0.630 & $\mathrm{~S} / \mathrm{E} / \mathrm{M}$ & $\begin{array}{l}\text { Based on total alpha activity sample result } \\
\text { ratioed to HDW estimates for alpha isotopes }\end{array}$ \\
\hline
\end{tabular}

Notes:

ICP = inductively coupled plasma (spectroscopy)

${ }^{1} \mathrm{~S}=$ sample-based (see Appendix B), $\mathrm{M}=\mathrm{HDW}$ model based (Agnew et al. 1997a), and $\mathrm{E}=$ engineering assessment based. 


\subsection{RECOMMENDATIONS}

Push-mode core samples (October through December 1997) and vapor samples (March 1995) were taken to satisfy the applicable issues associated with tank 241-SX-106. Analytical results from the core sample were within the prescribed limits of the safety screening and organic complexant DQOs. Retained gas samples were taken to evaluate flammable gas issues. Results of these tests are presented in Appendix B. The RGS results and gas bubble retention test results (not available at the time this tank characterization report was written) are being evaluated to further address the flammable gas DQO. The sampling and analysis activities performed for tank 241-SX-106 have met all requirements for all applicable DQO documents except for the organic solvent issue.

Vapor samples showed that ammonia is the only toxic vapor of concern and the LFL in the tank headspace is $<1$ percent. Specific analyses for total nonmethane organic hydrocarbon were not conducted in this tank (Huckaby and Bratzel 1995). However, the organic program has determined that even if an organic solvent pool does exist, the consequence of a fire or ignition of organic solvents is below risk evaluation guidelines for all of the tanks (Brown et al. 1998). Consequently, additional vapor analyses are not required for this tank. The organic solvent issue is expected to be closed for all tanks in fiscal year 1998.

Table 4-1 summarizes the Project Hanford Management Contractor (PHMC) TWRS program review status and acceptance of the sampling and analysis results reported in this tank characterization report. All issues required to be addressed by sampling and analysis are listed in column 1 of Table 4-1. Column 2 indicates by "yes" or "no" whether issue requirements were met by the sampling and analysis performed. Column 3 indicates concurrence and acceptance by the program in PHMC TWRS that is responsible for the applicable issue. A "yes" in column 3 indicates that no additional sampling or analyses are needed. Conversely, "no" indicates additional sampling or analysis may be needed to satisfy issue requirements. 
Table 4-1. Acceptance of Tank 241-SX-106 Sampling and Analysis.

\begin{tabular}{|c|c|c|}
\hline (1. & Gomping vin linilysis & 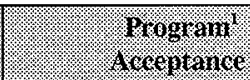 \\
\hline Safety screening DQO & Yes & Yes \\
\hline Flammable gas DQO & Yes & Yes \\
\hline Organic complexant $\mathrm{MOU}^{2}$ & Yes & Yes \\
\hline Organic solvent $\mathrm{DQO}^{2}$ & Yes & Yes \\
\hline
\end{tabular}

Notes:

'PHMC TWRS program office

${ }^{2}$ The organic complexant and organic solvent safety issues are expected to be closed in fiscal year 1998 .

Table 4-2 summarizes the status of PHMC TWRS program review and acceptance of the evaluations and other characterization information contained in this report. Column 1 lists the different evaluations performed in this report. Column 2 shows whether issue evaluations have been completed or are in progress. Column 3 indicates concurrence and acceptance with the evaluation by the program in PHMC TWRS that is responsible for the applicable issue. A "yes" indicates that the evaluation is completed and meets all issue requirements.

Table 4-2. Acceptance of Evaluation of Characterization Data and Information for Tank 241-SX-106.

\begin{tabular}{|c|c|c|}
\hline tessine & $\begin{array}{l}\text { Evaluation } \\
\text { Perromed }\end{array}$ & $\begin{array}{l}\text { Thers Program } \\
\text { Acceptance }\end{array}$ \\
\hline Safety screening DQO & Yes & Yes \\
\hline Flammable gas $\mathrm{DQO}^{2}$ & (in progress) & N/D \\
\hline Organic complexant $\mathrm{MOU}^{3}$ & Yes & Yes \\
\hline Organic solvent $\mathrm{DQO}^{3}$ & Yes & Yes \\
\hline
\end{tabular}

Notes:

$\mathrm{N} / \mathrm{D}=$ not determined

'PHMC TWRS Program Office

${ }^{2}$ The flammable gas unreviewed safety question is expected to be closed in fiscal year 1998 , final closure of this issue for all tanks is scheduled for fiscal year 2002.

${ }^{3}$ The organic complexant and organic solvent safery issues are expected to be closed in fiscal year 1998. 


\subsection{REFERENCES}

Agnew, S. F., J. Boyer, R. A. Corbin, T. B. Duran, J. R. Fitzpatrick, K. A. Jurgensen, T. P. Ortiz, and B. L. Young, 1997a, Hanford Tank Chemical and Radionuclide Inventories: HDW Model Rev. 4, LA-UR-96-3860, Los Alamos National Laboratory, Los Alamos, New Mexico.

Agnew, S. F., R. A. Corbin, T. B. Duran, K. A. Jurgensen, T. P. Ortiz, and B. L. Young, 1997b, Waste Status and Transaction Record Summary (WSTRS) Rev. 4, LA-UR-97-311, Los Alamos National Laboratory, Los Alamos, New Mexico

Bauer, R. E., and L. P. Jackson, 1998, Data Quality Objective to Support Resolution of the Flammable Gas Safety Issue, HNF-SD-WM-DQO-004, Rev. 3A, DE\&S Hanford, Inc., for Fluor Daniel Hanford, Inc., Richland, Washington.

Brown, T. M., J. W. Hunt, and L. J. Fergestrom, 1997, Tank Characterization Technical Sampling Basis, HNF-SD-WM-TA-164, Rev. 3, Lockheed Martin Hanford Corp. for Fluor Daniel Hanford, Inc., Richland, Washington.

Brown, T. M., J. W. Hunt, and L. J. Fergestrom, 1998, Tank Characterization Technical Sampling Basis, HNF-SD-WM-TA-164, Rev. 4, Lockheed Martin Hanford Corp. for Fluor Daniel Hanford, Inc. Richland, Washington.

Dukelow, G. T., J. W. Hunt, H. Babad, and J. E. Meacham, 1995, Tank Safety Screening Data Quality Objective, WHC-SD-WM-SP-004, Rev. 2, Westinghouse Hanford Company, Richland, Washington.

Ecology, EPA, and DOE, 1997, Hanford Federal Facility Agreement and Consent Order, as amended, Washington State Department of Ecology, U.S. Environmental Protection Agency, and U.S. Department of Energy, Olympia, Washington.

Hanlon, B. M., 1998, Waste Tank Summary Report for Month Ending May 31, 1998, HNF-EP-0182-122, Lockheed Martin Hanford Corp. for Fluor Daniel Hanford, Inc., Richland, Washington.

Hewitt, E. R., 1996, Tank Waste Remediation System Resolution of Potentially Hazardous Vapor Issues, WHC-SD-TWR-RPT-001, Rev. 0, Westinghouse Hanford Company, Richland, Washington.

Hodgson, K. M. and M. D. LeClair, 1996, Work Plan for Defining a Standard Inventory Estimate for Wastes Stored in Hanford Site Underground Tanks, WHC-SD-WM-WP-311, Rev. 1, Lockheed Martin Hanford Corp. for Fluor Daniel Hanford, Inc., Richland, Washington. 
Huckaby, J. L. and D. R. Bratzel, 1995, Tank 24I-SX-106 Headspace Gas and Vapor Characterization Results for Samples Collected in March 1995, WHC-SD-WM-ER-460, Rev. 1, Westinghouse Hanford Company, Richland, Washington.

Jo, J., 1997, Tank 241-SX-106 Push Mode Core Sampling and Analysis Plan, HNF-SD-WM-TSAP-148, Rev. 1, Lockheed Martin Hanford Corp. for Fluor Daniel Hanford, Inc., Richland, Washington.

Johnson, G. D., 1997, Strategy for Resolution of the Flammable Gas Safety Issue, HNF-SD-WM-ER-680, Rev. 0, DE\&S Hanford, Inc., for Fluor Daniel Hanford, Inc:, Richland, Washington.

Kummerer, M., 1995, Heat Removal Characteristics of Waste Storage Tanks, WHC-SD-WM-SARR-010, Rev. 1, Westinghouse Hanford Company, Richland, Washington.

Kupfer, M. J., A. L. Boldt, B. A. Higley, K. M. Hodgson, L. W. Shelton, B. C. Simpson, R. A. Watrous, M. D. LeClair, G. L. Borsheim, R. T. Winward, R. M. Orme, N. G. Colton, S. L. Lambert, D. E. Place, and W. W. Schulz, 1997, Standard Inventories of Chemicals and Radionuclides in Hanford Site Tank Wastes, HNF-SD-WM-TI-740, Rev. 0A, Lockheed Martin Hanford Corp. for Fluor Daniel Hanford, Inc., Richland, Washington.

LMHC, 1998, Tank Characterization Database, May 31, 1998, Internet at http://twins.pnl.gov:8001/TCD/main.html, Lockheed Martin Hanford Corp., Richland, Washington.

Mahoney, L. A., Z. I. Antoniak, and J. M. Bates, 1998, Preliminary Retained Gas Sampler Measurement Results for Hanford Waste Tank 241-SX-106, TWS98.33, Pacific Northwest National Laboratory, Richland, Washington.

Meacham, J. E., D. L. Banning, M. R. Allen, and L. D. Muhlestein, 1997, Data Quality Objective to Support Resolution of the Organic Solvent Safety Issue, HNF-SD-WM-DQO-026, Rev. 0, DE\&S Hanford, Inc., for Fluor Daniel Hanford, Inc., Richland, Washington.

Meacham, J. E., W. L. Cowley, A. B. Webb, N. W. Kirch, J. A. Lechelt, D. A. Reynolds, L. A. Stauffer, D. B. Bechtold, D. M. Camaioni, F. Gao, R. T. Hallen, P. G. Heasler, J. L. Huckaby, R. D. Scheele, C. S. Simmons, J. J. Toth, and L. M. Stock, 1998, Organic Complexant Topical Report, HNF-SD-WM-CN-058, Rev. 2, DE\&S Hanford, Inc., for Fluor Daniel Hanford, Inc., Richland, Washington. 
Osborne, J. W., and L. L. Buckley, 1995, Data Quality Objectives for Tank Hazardous Vapor Safety Screening, WHC-SD-WM-DQO-002, Rev. 2, Westinghouse Hanford Company, Richland, Washington.

Public Law 101-510, 1990, "Safety Measures for Waste Tanks at Hanford Nuclear Reservation," Section 3137 of National Defense Authorization Act for Fiscal Year 1991.

Sasaki, L. M., S. R. Wilmarth, and T. T. Tran, 1998, Tank.Characterization Report for Single-Shell Tank 241-U-103, HNF-SD-WM-ER-712, Rev. 1, Lockheed Martin Hanford Corp. for Fluor Daniel Hanford, Inc., Richland, Washington.

Schreiber, R. D., 1997, Memorandum of Understanding for the Organic Complexant Safety Issue Data Requirements, HNF-SD-WM-RD-060, Rev. 0, Lockheed Martin Hanford Corp. for Fluor Daniel Hanford, Inc., Richland, Washington.

Simpson, B. C., 1998, Best Basis Inventory Change Package for Reconciliation of Mercury Values, Change Package 7, (internal memorandum 7A120-98-005 to J. W. Cammann, February 26), Lockheed Martin Hanford Corp. for Fluor Daniel Hanford, Inc., Richland, Washington.

Smith, D. A., 1986, Single-Shell Tank Isolation Safety Analysis Report, WHC-SD-WM-SAR-006, Rev. 2, Westinghouse Hanford Company, Richland, Washington.

Watrous, R. A., and D. W. Wootan, 1997, Activity of Fuel Batches Processed Through Hanford Separations Plants, 1944 Through 1989, HNF-SD-WM-TI-794, Rev. 0, Lockheed Martin Hanford Corp. for Fiuor Daniel Hanford, Inc., Richland, Washington. 
HNF-SD-WM-ER-645 Rev. 1

This page intentionally left blank. 
APPENDIX A

HISTORICAL TANK INFORMATION 
This page intentionally left blank. 


\section{APPENDIX A}

\section{HISTORICAL TANK INFORMATION}

Appendix A describes tank 241-SX-106 based on historical information. For this report, historical information includes information about the fill history, waste types, surveillance, or modeling data about the tank. This information is necessary for providing a balanced assessment of sampling and analytical results.

This appendix contains the following information:

- Section A1.0: Current tank status, including the current waste levels and the tank stabilization and isolation status

- Section A2.0: Information about the tank design

- Section A3.0: Process knowledge about the tank, the waste transfer history, and the estimated contents of the tank based on modeling data

- Section A4.0: Surveillance data for tank 241-SX-106, including surface-level readings, temperatures, and a description of the waste surface based on photographs

- Section A5.0: References for Appendix A.

\section{A1.0 CURRENT TANK STATUS}

As of May 31, 1998, tank 241-SX-106 contained an estimated 2,037 kL (538 kgal) of noncomplexed waste (Hanlon 1998). The waste volumes were estimated using a Food Instrument Corporation surface-level gauge, photographic evaluation, and sludge level measurement device. Table Al-1 shows the volumes of the waste phases found in the tank.

Tank 241-SX-106 is out of service as are all single-shell tanks. This tank is categorized as sound with partial interim isolation completed in 1985 . The tank is actively ventilated and is on the Watch List (Public Law 101-510) for flammable gas and organics issues. 
Table A1-1. Tank Contents Status Summary. ${ }^{1}$

\begin{tabular}{|l|l|}
\hline \multicolumn{1}{|c|}{ Waste THe } & \\
\hline Total waste & $2,037(538)$ \\
\hline Supernatant & $231(61)$ \\
\hline Sludge & $45(12)$ \\
\hline Saltcake & $1,760(465)$ \\
\hline Drainable interstitial liquid & $848(224)$ \\
\hline Drainable liquid remaining & $1,080(285)$ \\
\hline Pumpable liquid remaining & $999(264)$ \\
\hline
\end{tabular}

Note:

${ }^{1}$ Hanlon (1998).

\section{A2.0 TANK DESIGN AND BACKGROUND}

The SX Tank Farm was constructed between 1953 and 1954 in the 200 West Area of the Hanford Site. The SX Tank Farm contains fifteen 100-series tanks. These tanks have a maximum capacity of $3,785 \mathrm{~kL}(1,000 \mathrm{kgal})$ and a diameter of $23 \mathrm{~m}(75 \mathrm{ft})$. Built according to the third-generation design, the 241-SX Tank Farm was designed for self-boiling waste (for a 5- to 10-year boiling period) with a maximum fluid temperature of $121^{\circ} \mathrm{C}\left(250^{\circ} \mathrm{F}\right)$ (Leach and Stahl 1997). Because the tanks were designed specifically for boiling waste, airlift circulators were installed to control waste temperatures.

Tank 241-SX-106 entered service in 1954 and is third in a three-tank cascading series. These tanks are connected by a 7.6-cm (3-in.) cascade line. The cascade overflow height is approximately $9.47 \mathrm{~m}$ (373 in.) from the tank bottom and $30 \mathrm{~cm}(1 \mathrm{ft})$ below the top of the steel liner. These single-shell tanks in the 241-SX Tank Farm are constructed of $61-\mathrm{cm}(2-\mathrm{ft})-$ thick, reinforced concrete with a $0.953-\mathrm{cm}(0.375 \mathrm{in}$.) mild carbon steel liner on the bottom and sides and a 38 -cm (1.25-ft)- thick, domed concrete top. These tanks have a dished bottom with an operating depth of $9.14 \mathrm{~m}(30 \mathrm{ft})$. The tanks are covered with approximately $2.21 \mathrm{~m}$ $(7.25 \mathrm{ft})$ of overburden.

Tank 241-SX-106 has 12 risers according to the drawings and engineering change notices. The risers range in diameter from $100 \mathrm{~mm}$ (4 in.) to $1.1 \mathrm{~m}$ (42 in.). Table A2-1 shows numbers, diameters, and descriptions of the risers. A plan view that depicts the riser and nozzle configuration is shown as Figure A2-1. Figure A2-2 is a tank cross section showing the approximate waste level along with a schematic of the tank equipment. 
Table A2-1. Tank 241-SX-106 Risers. ${ }^{1}$

\begin{tabular}{|c|c|c|}
\hline Nuniber: & Thaneret & Descruption and comments: \\
\hline $\mathrm{R} 1$ & 4 & Connection nozzle \\
\hline $\mathrm{R} 2$ & 4 & $\begin{array}{l}\text { Blind flange (benchmark Change Engineering Order } 36903 \text {; } \\
\text { December } 11,1986 \text { ) }\end{array}$ \\
\hline R3 & 4 & $\begin{array}{l}\text { Food Instrument Corporation gauge (ENRAF }{ }^{2} 854 \text {; Engineering Change } \\
\text { Notice 612693; August } 3,1994)\end{array}$ \\
\hline R4 & 4 & Dome riser \\
\hline R5 & 12 & Salt well screen and pump \\
\hline R6 & 12 & B-222 observation port \\
\hline R7 & 12 & $\begin{array}{l}\text { Blind flange [benchmark Change Engineering Order } 36903 \text {; } \\
\text { December 11, 1986) }\end{array}$ \\
\hline R8 & 12 & Condensate pump \\
\hline R11 & 4 & $\begin{array}{l}\text { Breather filter (benchmark Change Engineering Order 36903; } \\
\text { December 11, 1986) (standard hydrogen monitor system with air filter } \\
\text { W-369-012; December 20, 1994) }\end{array}$ \\
\hline R13 & 42 & Distributor riser \\
\hline R14 & 4 & B-436 liquid observation well \\
\hline R16 & 4 & Temperature probe \\
\hline $\mathrm{N} 1$ & 3 & Auxiliary fill \\
\hline $\mathrm{N} 2$ & 4 & Overflow inlet \\
\hline $\mathrm{N} 3$ & 8 & Spare, capped \\
\hline $\mathrm{N} 4$ & 4 & Overflow outlet \\
\hline
\end{tabular}

Note:

'Alstad (1993), Lipnicki (1997), Tran (1993), and Vitro (1985)

${ }^{2}$ ENRAF is a trademark of ENRAF Corporation, Houston, Texas. 
Figure A2-1. Riser Configuration for Tank 241-SX-106.

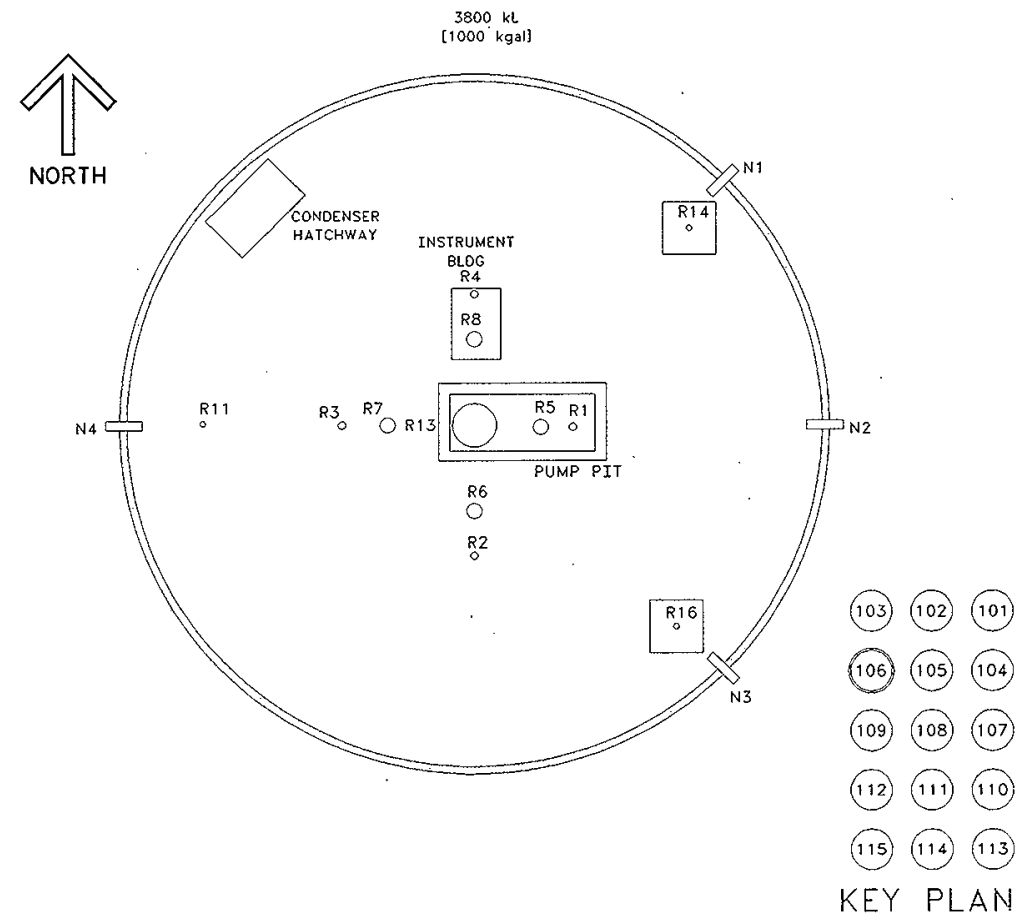


Figure A2-2. Tank 241-SX-106 Cross Section and Schematic.

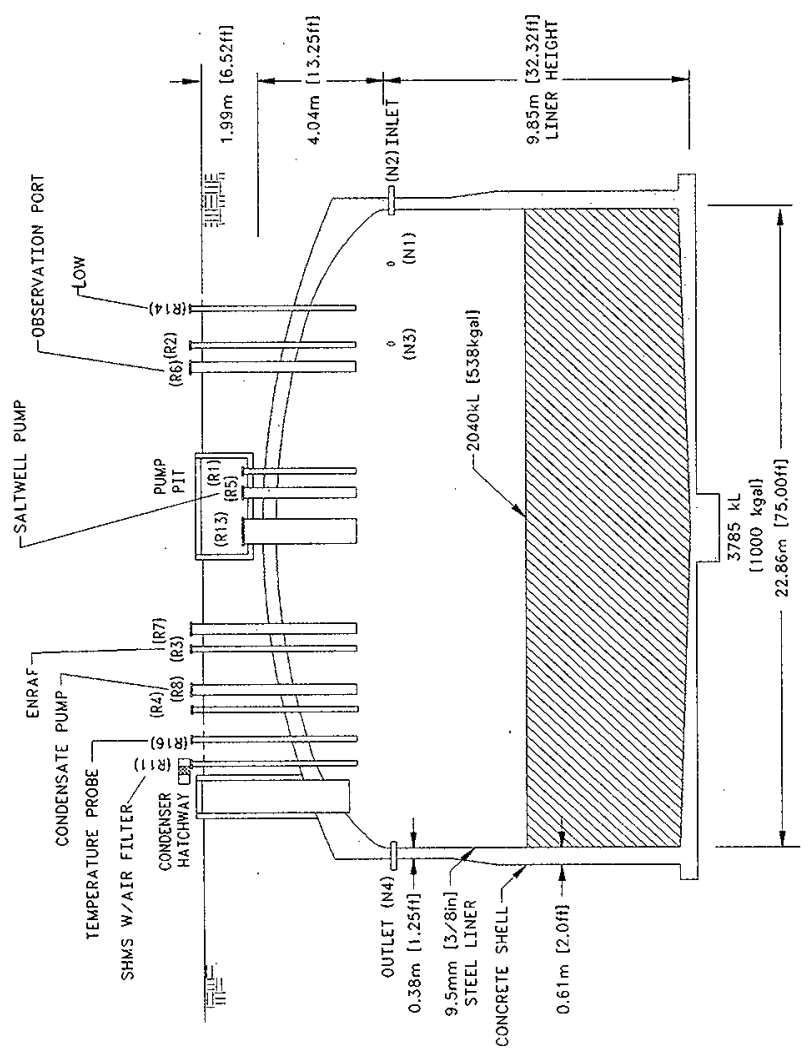




\section{A3.0 PROCESS KNOWLEDGE}

The sections below provide information about the transfer history of tank 241-SX-106, describe the process wastes that made up the transfers, and estimate the current tank contents based on transfer history.

\section{A3.1 WASTE TRANSFER HISTORY}

Table A3-1 summarizes the waste transfer history of tank 241-SX-106 (Agnew et al. 1997b). Waste, consisting of flush water from miscellaneous sources, was initially added to tank 241-SX-106 in the third quarter of 1954. From the fourth quarter of 1954 to the fourth quarter of 1963, the tank received condensate waste from various 241-SX tanks and miscellaneous sources. Waste was transferred from the tank to the S- 021 crib from the fourth quarter of 1954 to the third quarter of 1971. From the first quarter of 1956 to the second quarter of 1963, the tank received flush water from miscellaneous sources.. From the second to the fourth quarters of 1957, supernatant waste was sent to tank 241-SX-104. From the fourth quarter of 1958 to the third quarter of 1960 , the tank received sparge transfers of water from tanks 241-SX-103 and 241-SX-115. From the first quarter of 1959 to the second quarter of 1963, supernatant waste was transferred to various 241-SX tanks. In the fourth quarter of 1959 , flush water was sent from the tank to tank $241-\mathrm{SX}-114$.

In the second quarter of 1963, waste was transferred from the tank to the 202-S Plant for REDOX processing. From the second quarter of 1964 to the fourth quarter of 1975, flush water from miscellaneous sources was added to the tank. Some of this flush water consisted of Hanford Laboratory Operations and Battelle Pacific Northwest Laboratory waste. In the fourth quarter of 1971, waste was sent from the tank to tank 241-SX-111.

In support of the 242-S Evaporator campaign, supernatant waste was transferred to and received from tank 241-S-102 from the third quarter of 1972 to the fourth quarter of 1976. From the first quarter of 1972 to the second quarter of 1976, waste was transferred into and out of the tank into various tanks as feed staging for the 242-S Evaporator. From the second quarter of 1978 to the fourth quarter of 1980 , waste was transferred to and received from tank 241-SY-102 in support of the 242-S Evaporator campaign. Waste was transferred into and received from various tanks from the first quarter of 1978 to the fourth quarter of 1979 as feed staging for the 242-S Evaporator. In the third and fourth quarters of 1980, a neutralized solution of $\mathrm{HNO}_{3} / \mathrm{KMnO}_{4}$ was added to the tank to neutralize the waste and increase volume reduction. The tank was removed from service and labeled inactive in 1980. Water from miscellaneous sources (most likely attributed to tank intrusions such as rain water) was added to the tank from 1983 to 1993 . The tank was partially interim isolated in 1985 . 
Table A3-1. Tank 241-SX-106 Major Transfers. ${ }^{\mathrm{t}, 2,3}$ (2 sheets)

\begin{tabular}{|c|c|c|c|c|c|}
\hline \multirow{2}{*}{ Transter } & \multirow{2}{*}{$\begin{array}{l}\text { Transfer: } \\
\text { Destinationa }\end{array}$} & \multirow[b]{2}{*}{ Waste Tye } & \multirow[b]{2}{*}{ Trine Period } & \multicolumn{2}{|c|}{$\begin{array}{l}\text { Estinated Waste } \\
\text { volume }\end{array}$} \\
\hline & & & & (11: & kga! \\
\hline $\begin{array}{l}\text { Miscellaneous } \\
\text { sources }\end{array}$ & - & Flush water & 1954 & 57 & 15 \\
\hline $\begin{array}{l}241-S X-101 \\
241-S X-104 \\
241-S X-108 \\
241-S X-109 \\
241-S X-112 \\
241-S X-107 \\
241-S X-111 \\
241-S X-114 \\
241-S X-113 \\
241-S X-115 \\
241-S X-103 \\
241-S X-110\end{array}$ & - & Condensate & 1954 to 1963 & 53,579 & 14,154 \\
\hline $\begin{array}{l}\text { Miscellaneous } \\
\text { sources }\end{array}$ & - & Condensate & 1959 to 1960 & 500 & 132 \\
\hline- & S-021 crib & Supernatant & 1954 to 1971 & 44,418 & 11,734 \\
\hline $\begin{array}{l}\text { Miscellaneous } \\
\text { sources }\end{array}$ & - & Flush water & 1956 to 1963 & 2,059 & 544 \\
\hline- & 241-SX-104 & Supernatant & 1957 & 337 & 89 \\
\hline $\begin{array}{l}\text { 241-SX-103, } \\
241-S X-115\end{array}$ & - & Sparge water & 1958 to 1960 & 814 & 215 \\
\hline- & \begin{tabular}{|l}
$241-S X-107$ \\
$241-S X-108$ \\
$241-S X-114$ \\
$241-S X-111$ \\
$241-S X-115$ \\
$241-S X-102$ \\
$241-S X-105$
\end{tabular} & Supernatant & 1959 to 1963 & 7,813 & 2,064 \\
\hline-- & 241-SX-114 & Flush water & 1959 & 76 & 20 \\
\hline-- & 202-S (REDOX) & Supernatant & 1963 & 95 & 25 \\
\hline $\begin{array}{l}\text { Miscellaneous } \\
\text { sources }\end{array}$ & -- & Flush water & 1964 to 1975 & 3,717 & 982 \\
\hline- & 241-SX-111 & Supernatant & 1971 & 644 & 170 \\
\hline-- & $241-\mathrm{S}-102$ & Evaporator feed & 1972 to 1976 & 49,562 & 13,093 \\
\hline $241-S-102$ & - & Evaporator bottoms & 1972 to 1976 & 24,590 & 6,496 \\
\hline
\end{tabular}


Table A3-1. Tank 241-SX-106 Major Transfers. ${ }^{1,2,3}$ (2 sheets)

\begin{tabular}{|c|c|c|c|c|c|}
\hline \multirow{2}{*}{$\begin{array}{l}\text { Transfer } \\
\text { Source }\end{array}$} & \multirow{2}{*}{$\begin{array}{l}\text { Thansfer } \\
\text { Destination }\end{array}$} & \multirow[b]{2}{*}{ Waste Mpe } & \multirow[b]{2}{*}{ Trine reniod. } & \multicolumn{2}{|c|}{ Estinarted Waste } \\
\hline & & & & 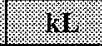 & I $\mathrm{kgal}$. \\
\hline $\begin{array}{l}241-\mathrm{SX}-105, \\
241-\mathrm{BX}-103, \\
241-\mathrm{C}-103, \\
\text { 241-TX-107, } \\
\text { 241-T-101, } \\
\text { 241-B-102, } \\
\text { 241-BX-106, } \\
\text { 241-C-104 }\end{array}$ & - & Evaporator feed & 1972 to 1976 & 29,401 & 7,767 \\
\hline-- & $\begin{array}{l}\text { 241-SX-114, } \\
\text { 241-SX-102 }\end{array}$ & Supernatant & 1972 to 1974 & 2,324 & 614 \\
\hline-- & 241-SY-102 & Evaporator feed & 1978 to 1980 & 13,059 & 3,449 \\
\hline 241-SY-102 & - & Evaporator bottoms & 1978 to 1980 & 9,127 & 2,411 \\
\hline- & $\begin{array}{l}241-S Y-103, \\
241-S Y-101, \\
241-S-102, \\
241-S X-101\end{array}$ & Supernatant & 1978 to 1979 & 6,079 & 1,606 \\
\hline $\begin{array}{l}241-\mathrm{U}-111 \\
241-\mathrm{S}-102 \\
241-\mathrm{U}-107 \\
241-\mathrm{TX}-118 \\
241-\mathrm{S}-107\end{array}$ & {$[-$} & Evaporator feed & 1978 to 1979 & 7,696 & 2,033 \\
\hline $\begin{array}{l}\text { Miscellaneous } \\
\text { sources }\end{array}$ & - & $\begin{array}{l}\text { Neutralized waste } \\
\left(\mathrm{HNO}_{3} / \mathrm{KMnO}_{4}\right. \\
\text { solution) }\end{array}$ & 1980 & 522 & 138 \\
\hline $\begin{array}{l}\text { Miscellaneous } \\
\text { sources }\end{array}$ & - & Flush water & 1983 to 1993 & 231 & 61 \\
\hline
\end{tabular}

Notes:

Waste volumes and types are best estimates based on historical data.

'Agnew et al. (1997b)

'Because only major transfers are listed, the sum of these transfers will not equal the current tank waste volume.

${ }^{3}$ Waste evaporated from tank is not included in this table. 


\section{A3.2 HISTORICAL ESTIMATION OF TANK CONTENTS}

The historical transfer data used for this estimate are from the following sources.

- The Waste Status and Transaction Record Summary (WSTRS) Rev. 4 (Agnew et al. 1997b) is a tank-by-tank quarterly summary spreadsheet of waste transactions.

- The Hanford Tank Chemical and Radionuclide Inventories: HDW Model Rev. 4 (Agnew et al. 1997a) contains the HDW list, the SMM, the tank layer model (TLM), and the historical tank content estimate.

- The HDW list is comprised of approximately 50 waste types defined by concentration for major analytes/compounds for sludge and supernatant layers.

- The TLM defines the sludge and saltcake layers in each tank using waste composition and waste transfer information.

- The SMM is a subroutine within the HDW model that calculates the volume and composition of certain supernatant blends and concentrates.

Using these records, the TLM defines the sludge and saltcake layers in each tank. The SMM uses information from the waste status and transaction record summary, the TLM, and the HDW. list to describe the supernatants and concentrates in each tank. Together the waste status and transaction record summary, TLM, SMM, and HDW list determine the inventory estimate for each tank. These model predictions are considered estimates that require further evaluation using analytical data.

Based on the TLM and SMM, tank 241-SX-106 contains four layers. A top layer of $231 \mathrm{~kL}$ ( $61 \mathrm{kgal}$ ) of supernatant is predicted to be above a layer of $1,477 \mathrm{~kL}$ (390 kgal) of SMMS2, over a layer of $326 \mathrm{~kL}$ ( $86 \mathrm{kgal}$ ) of SMMS1, over a bottom layer of $3.7 \mathrm{~kL}(1 \mathrm{kgal})$ of REDOX saltcake. Figure A3-1 is a graphical representation of the estimated waste type and volume for the tank layer.

The REDOX saltcake layer should contain the following major constituents listed from highest concentration above one weight percent: sodium, nitrate, nitrite, hydroxide, aluminum, and chromium. Constituents above one weight percent in the SMMS1 layer are nitrate, sodium, hydroxide, nitrite, aluminum, carbonate, and sulfate. Constituents above one weight percent in the SMMS2 layer are sodium, nitrate, hydroxide, nitrite, aluminum, sulfate, carbonate, phosphate, and TOC. Table A3-2 shows the historical estimate of the expected waste constituents and their concentrations. 
Figure A3-1. Tank Layer Model.

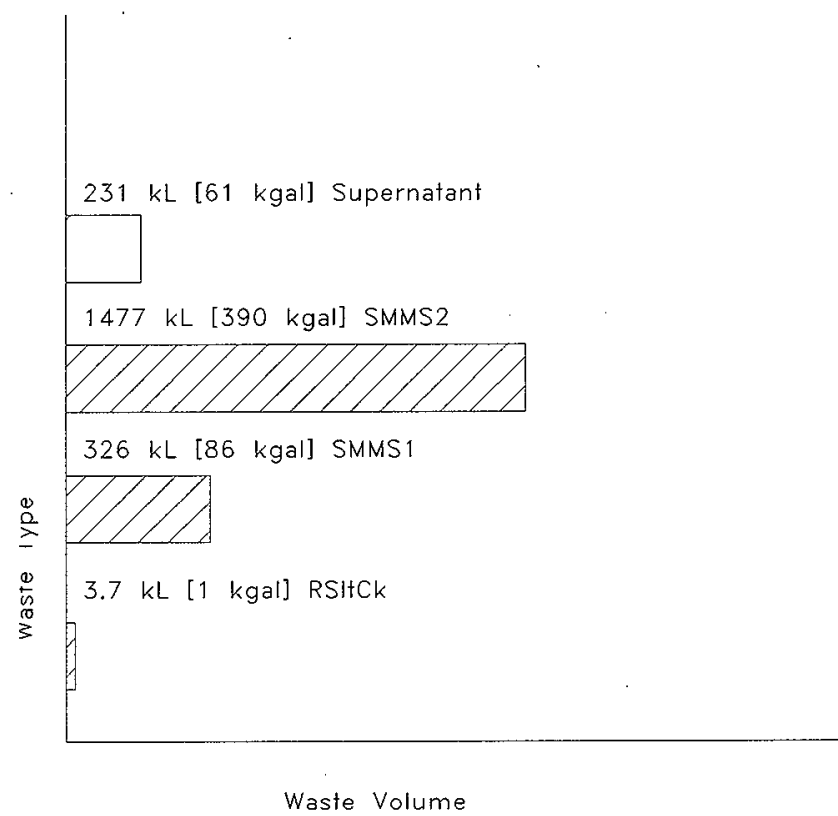


Table A3-2. Historical Tank Inventory Estimate. ${ }^{1,2}$ (4 sheets)

\begin{tabular}{|c|c|c|c|c|c|}
\hline (2:-: & 1 & Yhentory $\mathrm{E}$ & stimate & & \\
\hline Plysical Proparties. & & (2:-5: & & .9501 & 1.95 .01 \\
\hline Total waste & $3.27 \mathrm{E}+06$ & $538 \mathrm{kgal})$ & & -- & -- \\
\hline Heat load & $4.31 \mathrm{~kW}$ & $\mathrm{E}+04 \mathrm{Btu} / \mathrm{hr}$ & & 4.05 & 4.58 \\
\hline Bulk density ${ }^{3}$ & $1.61(\mathrm{~g} / \mathrm{cm}$ & & & 1.56 & 1.65 \\
\hline Water wt $\%^{3}$ & 32.7 & & & 30.1 & 36.0 \\
\hline $\begin{array}{l}\text { TOC wt\% carbon } \\
\text { (wet) })^{3}\end{array}$ & 0.749 & & & 0.490 & 1.01 \\
\hline Consfinients & 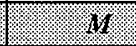 & aporin & igg't & .95 .1140 & $1.9501(1)$ \\
\hline $\mathrm{Na}^{+}$ & 14.2 & $2.03 E+05$ & $6.66 \mathrm{E}+05$ & 13.0 & 15.2 \\
\hline $\mathrm{Al}^{3+}$ & 1.67 & $2.81 \mathrm{E}+04$ & $9.19 \mathrm{E}+04$ & 1.55 & 1.79 \\
\hline $\mathrm{Fe}^{3+}$ & $1.09 \mathrm{E}-02$ & 379 & $1.24 \mathrm{E}+03$ & 8.95E-03 & $1.29 \mathrm{E}-02$ \\
\hline $\mathrm{Cr}^{3+}$ & 0.149 & $4.83 \mathrm{E}+03$ & $1.58 \mathrm{E}+04$ & 0.125 & 0.157 \\
\hline $\mathrm{Bi}^{3+}$ & $1.38 \mathrm{E}-03$ & 179 & 586 & $1.25 \mathrm{E}-03$ & $1.50 \mathrm{E}-03$ \\
\hline $\mathrm{La}^{3+}$ & $4.13 \mathrm{E}-05$ & 3.57 & 11.7 & $2.99 \mathrm{E}-05$ & $5.28 \mathrm{E}-05$ \\
\hline $\mathrm{Hg}^{2+}$ & $9.25 \mathrm{E}-06$ & 1.15 & 3.78 & $8.59 \mathrm{E}-06$ & 9.52E-06 \\
\hline $\mathrm{Zr}$ & $2.60 \mathrm{E}-04$ & 14.7 & 48.2 & $2.36 \mathrm{E}-04$ & $2.82 \mathrm{E}-04$ \\
\hline $\mathrm{Pb}^{2+}$ & $1.01 \mathrm{E}-03$ & 130 & 425 & $8.16 \mathrm{E}-04$ & 1.20E-03 \\
\hline $\mathrm{Ni}^{2+}$ & $6.52 \mathrm{E}-03$ & 238 & 779 & $6.23 \mathrm{E}-03$ & $6.66 \mathrm{E}-03$ \\
\hline $\mathrm{Sr}^{2+}$ & 0 & 0 & 0 & 0 & 0 \\
\hline $\mathrm{Mn}^{4+}$ & $3.88 \mathrm{E}-03$ & 133 & 435 & $2.94 \mathrm{E}-03$ & $4.83 \mathrm{E}-03$ \\
\hline $\mathrm{Ca}^{2+}$ & $3.42 \mathrm{E}-02$ & 852 & $2.79 \mathrm{E}+03$ & $3.14 \mathrm{E}-02$ & $3.70 \mathrm{E}-02$ \\
\hline $\mathrm{K}^{+}$ & $6.59 \mathrm{E}-02$ & $1.60 \mathrm{E}+03$ & $5.25 \mathrm{E}+03$ & $6.02 \mathrm{E}-02$ & $7.20 \mathrm{E}-02$ \\
\hline $\mathrm{OH}^{-}$ & 9.99 & $1.06 \mathrm{E}+05$ & $3.46 \mathrm{E}+05$ & 9.23 & 10.6 \\
\hline $\mathrm{NO}^{3-}$ & 5.09 & $1.96 \mathrm{E}+05$ & $6.42 \mathrm{E}+05$ & 4.68 & 5.22 \\
\hline $\mathrm{NO}^{2-}$ & 2.45 & $7.00 \mathrm{E}+04$ & $2.29 \mathrm{E}+05$ & 2.04 & 2.85 \\
\hline $\mathrm{CO}_{3}{ }^{2-}$ & 0.434 & $1.62 \mathrm{E}+04$ & $5.31 \mathrm{E}+04$ & 0.394 & 0.470 \\
\hline $\mathrm{PO}_{4}^{3-}$ & $9.14 \mathrm{E}-02$ & $5.40 \mathrm{E}+03$ & $1.77 \mathrm{E}+04$ & $7.82 \mathrm{E}-02$ & $9.61 \mathrm{E}-02$ \\
\hline $\mathrm{SO}_{4}^{2-}$ & 0.245 & $1.46 \mathrm{E}+04$ & $4.79 \mathrm{E}+04$ & 0.193 & 0.297 \\
\hline $\mathrm{Si}$ & $7.81 \mathrm{E}-02$ & $1.36 \mathrm{E}+03$ & $4.47 \mathrm{E}+03$ & $6.46 \mathrm{E}-02$ & $9.16 \mathrm{E}-02$ \\
\hline$F$ & $6.76 \mathrm{E}-02$ & 799 & $2.62 \mathrm{E}+03$ & $5.66 \mathrm{E}-02$ & $7.73 \mathrm{E}-02$ \\
\hline $\mathrm{Cl}^{-}$ & 0.246 & $5.41 \mathrm{E}+03$ & $1.77 \mathrm{E}+04$ & 0.223 & 0.265 \\
\hline $\mathrm{C}_{6} \mathrm{H}_{5} \mathrm{O}_{7}^{3-}$ & $2.75 \mathrm{E}-02$ & $3.24 \mathrm{E}+03$ & $1.06 \mathrm{E}+04$ & $2.53 \mathrm{E}-02$ & $2.98 \mathrm{E}-02$ \\
\hline
\end{tabular}


Table A3-2. Historical Tank Inventory Estimate. ${ }^{1,2}$ (4 sheets)

\begin{tabular}{|c|c|c|c|c|c|}
\hline & 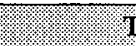 & Inventory & stinate : & 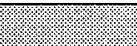 & (3). \\
\hline Constituents (Cont 0$)$ & (4. & (1) ppri: & (1) & 9501 & 1.7 .9501 \\
\hline EDTA $^{4-}$ & $1.48 \mathrm{E}-02$ & $2.66 \mathrm{E}+03$ & $8.70 \mathrm{E}+03$ & $4.54 \mathrm{E}-03$ & $2.53 \mathrm{E}-02$ \\
\hline HEDTA $^{3-}$ & $2.77 \mathrm{E}-02$ & $4.73 \mathrm{E}+03$ & $1.55 \mathrm{E}+04$ & $7.14 \mathrm{E}-03$ & 4.87E-02 \\
\hline Glycolate & $8.74 \mathrm{E}-02$ & $4.08 \mathrm{E}+03$ & $1.33 \mathrm{E}+04$ & $5.72 \mathrm{E}-02$ & 0.118 \\
\hline Acetate & $6.20 \mathrm{E}-03$ & 227 & 745 & $5.09 \mathrm{E}-03$ & $7.31 \mathrm{E}-03$ \\
\hline Oxalate $^{2-}$ & $5.41 \mathrm{E}-05$ & 2.96 & 9.70 & $4.79 \mathrm{E}-05$ & $6.03 \mathrm{E}-05$ \\
\hline DBP & $1.88 \mathrm{E}-02$ & $2.45 \mathrm{E}+03$ & $8.03 \mathrm{E}+03$ & $1.54 \mathrm{E}-02$ & $2.20 \mathrm{E}-02$ \\
\hline Butanol & $1.88 \mathrm{E}-02$ & 865 & $2.83 \mathrm{E}+03$ & $1.54 \mathrm{E}-02$ & $2.20 \mathrm{E}-02$ \\
\hline $\mathrm{NH}_{3}$ & $8.69 \mathrm{E}-02$ & 918 & $3.01 \mathrm{E}+03$ & $7.17 \mathrm{E}-02$ & 0.112 \\
\hline $\mathrm{Fe}(\mathrm{CN})_{6}^{4-}$ & 0 & 0 & 0 & 0 & 0 \\
\hline $\begin{array}{l}\text { Radiologiral: } \\
\text { Constituents: }\end{array}$ & 111 & 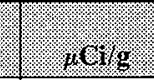 & $\sqrt{1 /} \cdot 1$. & 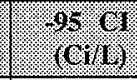 & $\begin{array}{l}.95 .11 \\
(011)\end{array}$ \\
\hline${ }^{3} \mathrm{H}$ & $2.52 \mathrm{E}-04$ & 0.157 & 513 & 1.32E-04 & $2.70 \mathrm{E}-04$ \\
\hline${ }^{14} \mathrm{C}$ & 3.62E-05 & $2.25 \mathrm{E}-02$ & 73.7 & $1.11 \mathrm{E}-05$ & $3.73 \mathrm{E}-05$ \\
\hline${ }^{59} \mathrm{Ni}$ & $2.36 \mathrm{E}-06$ & $1.47 \mathrm{E}-03$ & 4.80 & 1.18E-06 & $2.47 \mathrm{E}-06$ \\
\hline${ }^{63} \mathrm{Ni}$ & 2.31E-04 & 0.144 & 470 & $1.14 \mathrm{E}-04$ & 2.43E-04 \\
\hline${ }^{60} \mathrm{Co}$ & $4.01 E-05$ & $2.49 \mathrm{E}-02$ & 81.6 & 1.13E-05 & $4.16 \mathrm{E}-05$ \\
\hline${ }^{79} \mathrm{Se}$ & 3.61E-06 & $2.24 \mathrm{E}-03$ & 7.35 & 2.00E-06 & $4.74 \mathrm{E}-06$ \\
\hline${ }^{90} \mathrm{Sr}$ & 0.120 & 74.8 & $2.45 \mathrm{E}+05$ & 0.112 & 0.128 \\
\hline${ }^{90} \mathrm{Y}$ & 0.120 & 74.8 & $2.45 \mathrm{E}+05$ & $6.49 \mathrm{E}-02$ & 0.128 \\
\hline${ }^{93} \mathrm{Zr}$ & 1.77E-05 & $1.10 \mathrm{E}-02$ & 36.1 & $9.69 \mathrm{E}-06$ & $2.34 \mathrm{E}-05$ \\
\hline${ }^{93 \mathrm{~m}} \mathrm{Nb}$ & $1.29 \mathrm{E}-05$ & $8.00 \mathrm{E}-03$ & 26.2 & $7.25 \mathrm{E}-06$ & $1.68 \mathrm{E}-05$ \\
\hline${ }^{99} \mathrm{Tc}$ & $2.58 \mathrm{E}-04$ & 0.160 & 525 & $1.64 \mathrm{E}-04$ & 3.53E-04 \\
\hline${ }^{106} \mathrm{Ru}$ & 7.13E-09 & $4.44 \mathrm{E}-06$ & $1.45 \mathrm{E}-02$ & $3.42 \mathrm{E}-09$ & $8.72 \mathrm{E}-09$ \\
\hline${ }^{113 \mathrm{~m}} \mathrm{Cd}$ & 9.27E-05 & $5.76 \mathrm{E}-02$ & $189^{\circ}$ & $4.46 \mathrm{E}-05$ & $1.27 \mathrm{E}-04$ \\
\hline${ }^{125} \mathrm{Sb}$ & $1.72 \mathrm{E}-04$ & 0.107 & 351 & $4.78 \mathrm{E}-05$ & $1.79 \mathrm{E}-04$ \\
\hline${ }^{126} \mathrm{Sn}$ & $5.45 \mathrm{E}-06$ & 3.39E-03 & 11.1 & 3.05E-06 & $7.16 \mathrm{E}-06$ \\
\hline${ }^{129} \mathrm{I}$ & $4.97 \mathrm{E}-07$ & $3.09 \mathrm{E}-04$ & 1.01 & 3.16E-07 & $6.81 \mathrm{E}-07$ \\
\hline${ }^{134} \mathrm{Cs}$ & $2.73 \mathrm{E}-06$ & $1.70 \mathrm{E}-03$ & 5.57 & $1.95 \mathrm{E}-06$ & $3.53 \mathrm{E}-06$ \\
\hline${ }^{137} \mathrm{Cs}$ & 0.279 & 174 & $5.68 \mathrm{E}+05$ & 0.251 & 0.307 \\
\hline${ }^{137 \mathrm{~m}} \mathrm{Ba}$ & 0.264 & 164 & $5.38 \mathrm{E}+05$ & 0.207 & 0.291 \\
\hline
\end{tabular}


Table A3-2. Historical Tank Inventory Estimate. ${ }^{1,2}$ (4 sheets)

\begin{tabular}{|c|c|c|c|c|c|}
\hline 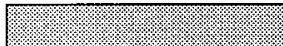 & & ninentory & Sthate & & \\
\hline 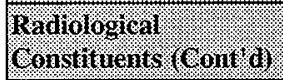 & (1115: & . & 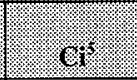 & $=-95.9)$ & $\begin{array}{l}.95 .9 \\
(c 111)\end{array}$ \\
\hline${ }^{151} \mathrm{Sm}$ & $1.27 \mathrm{E}-02$ & 7.90 & $2.59 \mathrm{E}+04$ & $7.09 \mathrm{E}-03$ & $1.67 \mathrm{E}-02$ \\
\hline${ }^{152} \mathrm{Eu}$ & 4.17E-06 & $2.59 \mathrm{E}-03$ & 8.49 & $2.18 \mathrm{E}-06$ & $4.73 \mathrm{E}-06$ \\
\hline${ }^{154} \mathrm{Eu}$ & $6.51 \mathrm{E}-04$ & 0.405 & $1.33 \mathrm{E}+03$ & $2.50 \mathrm{E}-04$ & 8.53E-04 \\
\hline${ }^{155} \mathrm{Eu}$ & $2.46 \mathrm{E}-04$ & 0.153 & 501 & $1.28 \mathrm{E}-04$ & 2.81E-04 \\
\hline${ }^{226} \mathrm{Ra}$ & $1.55 \mathrm{E}-10$ & $9.62 \mathrm{E}-08$ & $3.15 \mathrm{E}-04$ & $1.05 \mathrm{E}-10$ & $1.90 \mathrm{E}-10$ \\
\hline${ }^{228} \mathrm{Ra}$ & $1.51 \mathrm{E}-07$ & $9.37 \mathrm{E}-05$ & 0.307 & $6.31 \mathrm{E}-08$ & $2.58 \mathrm{E}-07$ \\
\hline${ }^{227} \mathrm{Ac}$ & $9.78 \mathrm{E}-10$ & $6.08 \mathrm{E}-07$ & $1.99 \mathrm{E}-03$ & $6.90 \mathrm{E}-10$ & $1.18 \mathrm{E}-09$ \\
\hline${ }^{231} \mathrm{~Pa}$ & 4.48E-09 & $2.79 \mathrm{E}-06$ & $9.13 \mathrm{E}-03$ & 2.88E-09 & $5.62 \mathrm{E}-09$ \\
\hline${ }^{229} \mathrm{Th}$ & $3.53 \mathrm{E}-09$ & $2.20 \mathrm{E}-06$ & 7.20E-03 & $1.61 \mathrm{E}-09$ & $5.89 \mathrm{E}-09$ \\
\hline${ }^{232} \mathrm{Th}$ & $1.00 \mathrm{E}-08$ & $6.24 \mathrm{E}-06$ & 2.04E-02 & $5.19 \mathrm{E}-09$ & $1.49 \mathrm{E}-08$ \\
\hline${ }^{232} \mathbf{U}$ & $7.75 \mathrm{E}-07$ & $4.82 \mathrm{E}-04$ & 1.58 & $4.24 \mathrm{E}-07$ & $1.21 \mathrm{E}-06$ \\
\hline${ }^{233} \mathrm{U}$ & $2.97 \mathrm{E}-06$ & $1.85 \mathrm{E}-03$ & 6.05 & $1.63 \mathrm{E}-06$ & 4.62E-06 \\
\hline${ }^{234} \mathrm{U}$ & 8.70E-07 & $5.41 \mathrm{E}-04$ & 1.77 & $8.38 \mathrm{E}-07$ & 8.97E-07 \\
\hline${ }^{235} \mathrm{U}$ & 3.53E-08 & $2.19 \mathrm{E}-05$ & 7.19E-02 & $3.39 \mathrm{E}-08$ & $3.64 \mathrm{E}-08$ \\
\hline${ }^{236} \mathrm{U}$ & $2.73 \mathrm{E}-08$ & $1.70 \mathrm{E}-05$ & $5.55 \mathrm{E}-02$ & 2.63E-08 & 2.81E-08 \\
\hline${ }^{238} \mathrm{U}$ & 1.01E-06 & $6.27 \mathrm{E}-04$ & 2.05 & $9.75 \mathrm{E}-07$ & $1.03 \mathrm{E}-06$ \\
\hline${ }^{237} \mathrm{~Np}$ & $9.42 \mathrm{E}-07$ & $5.86 \mathrm{E}-04$ & 1.92 & $6.36 \mathrm{E}-07$ & $1.25 \mathrm{E}-06$ \\
\hline${ }^{238} \mathrm{Pu}$ & $1.47 \mathrm{E}-06$ & $9.16 \mathrm{E}-04$ & 3.00 & $1.11 \mathrm{E}-06$ & $1.83 \mathrm{E}-06$ \\
\hline${ }^{239} \mathrm{Pu}$ & $5.06 \mathrm{E}-05$ & $3.15 \mathrm{E}-02$ & 103 & $4.14 \mathrm{E}-05$ & $5.98 \mathrm{E}-05$ \\
\hline${ }^{240} \mathrm{Pu}$ & $8.58 \mathrm{E}-06$ & $5.34 \mathrm{E}-03$ & 17.5 & $6.86 \mathrm{E}-06$ & $1.03 \mathrm{E}-05$ \\
\hline${ }^{241} \mathrm{Pu}$ & 9.95E-05 & $6.19 \mathrm{E}-02$ & 203 & $7.50 \mathrm{E}-05$ & 1.24E-04 \\
\hline${ }^{242} \mathrm{Pu}$ & $5.46 \mathrm{E}-10$ & $3.40 \mathrm{E}-07$ & $1.11 \mathrm{E}-03$ & $4.00 \mathrm{E}-10$ & $6.93 \mathrm{E}-10$ \\
\hline${ }^{241} \mathrm{Am}$ & $6.14 \mathrm{E}-05$ & $3.82 \mathrm{E}-02$ & 125 & $4.44 \mathrm{E}-05$ & $7.85 \mathrm{E}-05$ \\
\hline${ }^{243} \mathrm{Am}$ & $2.13 \mathrm{E}-09$ & $1.32 \mathrm{E}-06$ & $4.34 \mathrm{E}-03$ & $1.59 \mathrm{E}-09$ & 2.69E-09 \\
\hline${ }^{242} \mathrm{Cm}$ & $1.57 \mathrm{E}-07$ & $9.78 \mathrm{E}-05$ & 0.320 & $7.58 \mathrm{E}-08$ & $1.79 \mathrm{E}-07$ \\
\hline${ }^{243} \mathrm{Cm}$ & $1.46 \mathrm{E}-08$ & $9.06 \mathrm{E}-06$ & $2.97 \mathrm{E}-02$ & $6.79 \mathrm{E}-09$ & 1.65E-08 \\
\hline${ }^{244} \mathrm{Cm}$ & $1.44 \mathrm{E}-07$ & 8.95E-05 & 0.293 & $6.38 \mathrm{E}-08$ & $1.88 \mathrm{E}-07$ \\
\hline
\end{tabular}


Table A3-2. Historical Tank Inventory Estimate. ${ }^{1,2}$ (4 sheets)

\begin{tabular}{|c|c|c|c|c|c|}
\hline & Yoral & $14 \mathrm{cmin} / \mathrm{x}$ & stmato & & \\
\hline Hotals & $11 \%$ & 1498 & fg & 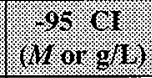 & 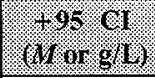 \\
\hline $\mathrm{Pu}$ & $6.35 \mathrm{E}-04(\mathrm{~g} / \mathrm{L})$ & --- & 1.29 & $4.61 \mathrm{E}-04$ & $8.08 \mathrm{E}-04$ \\
\hline $\bar{U}$ & $9.96 \mathrm{E}-03$ & $1.47 \mathrm{E}+03$ & $4.83 E+03$ & $9.55 \mathrm{E}-03$ & $1.03 \mathrm{E}-02$ \\
\hline
\end{tabular}

Notes:

$\mathrm{CI}=$ confidence interval

'Agnew et al. (1997a)

${ }^{2}$ These predictions have not been validated and should be used with caution.

${ }^{3}$ This is the volume average for density, mass average water wt\% and TOC wt\% carbon.

${ }^{4}$ Differences exist among the inventories in this column and the inventories calculated from the two sets of concentrations.

${ }^{5}$ Unknowns in tank solids inventory are assigned by the TLM.

\section{A4.0 SURVEILLANCE DATA}

Tank 241-SX-106 surveillance consists of surface-level measurements (liquid and solid), temperature monitoring inside the tank (waste and headspace), dry-well monitoring, and a SHMS. Surveillance data provide the basis for determining tank integrity.

Liquid-level measurements and dry-well measurements can indicate whether the tank has a major leak. Solid surface-level measurements can indicate physical changes in and consistencies of the solid layers of a tank. The SHMS primarily monitors hydrogen gas concentration in the tank headspace.

\section{A4.1 SURFACE-LEVEL READINGS}

Tank 241-SX-106 is categorized as a sound tank. Before August 1994 a Food Instrument Corporation gauge or manual tape was used to measure surface level. The Food Instrument Corporation gauge has been replaced by an ENRAF ${ }^{\mathrm{TM}}$ gauge that is used to monitor the surface level through riser 3. On May 31, 1998, the waste surface level was $503 \mathrm{~cm}$ (198 in.) as measured by the manual and automatic ENRAF $^{\mathrm{TM}}$ gauges. Figure A4-1 is a level history graph of the volume measurements. 


\section{A4.2 DRY-WELL READINGS}

Tank 241-SX-106 has four dry wells. None of the dry wells has radiation readings greater than 200 counts per second.

\section{A4.3 INTERNAL TANK TEMPERATURES}

Tank 241-SX-106 has a single thermocouple tree with six thermocouples to monitor the waste temperature through riser 16 . Temperature readings are available from the Surveillance Analysis Computer System from February 1988 to May 1998 (LMHC 1998). Thermocouple elevations and current temperature data are recorded for thermocouples 1 through 6.

The average temperature between May 31,1997 , and May 31,1998 , was $37.9^{\circ} \mathrm{C}\left(100.2^{\circ} \mathrm{F}\right)$, the minimum temperature was $28.3^{\circ} \mathrm{C}\left(82.9^{\circ} \mathrm{F}\right)$, and the maximum temperature was $42.1^{\circ} \mathrm{C}$ $\left(107.8^{\circ} \mathrm{F}\right)$. A graph of the weekly high temperatures can be found in Figure A4-2. Plots of the individual thermocouple readings can be found in the Supporting Document for the Historical Tank Content Estimate for SX-Tank Farm (Brevick et al. 1997).

\section{A4.4 STANDARD HYDROGEN MONITORING SYSTEM}

Wilkins et al. (1997) describes the SHMS type B that monitors the vapor phase in the tank 241-SX-106 headspace. The SHMS measures parts-per-million levels of hydrogen, methane, and nitrous oxide. The tank 241-SX-106 SHMS went into service in March 1995. Section B2.3.1 presents the surveillance results from the SHMS.

\section{A4.5 TANK 241-SX-106 PHOTOGRAPHS}

The June 1989 photographic montage of the interior of tank 241-SX-106 shows a lightcolored, thin, saltcake surface with dark liquid underneath. Various pieces of equipment are visible. The waste level has not changed significantly since the photographs were taken; therefore, the photographic montage should represent the current appearance of the waste in the tank (Brevick et al. 1997). 


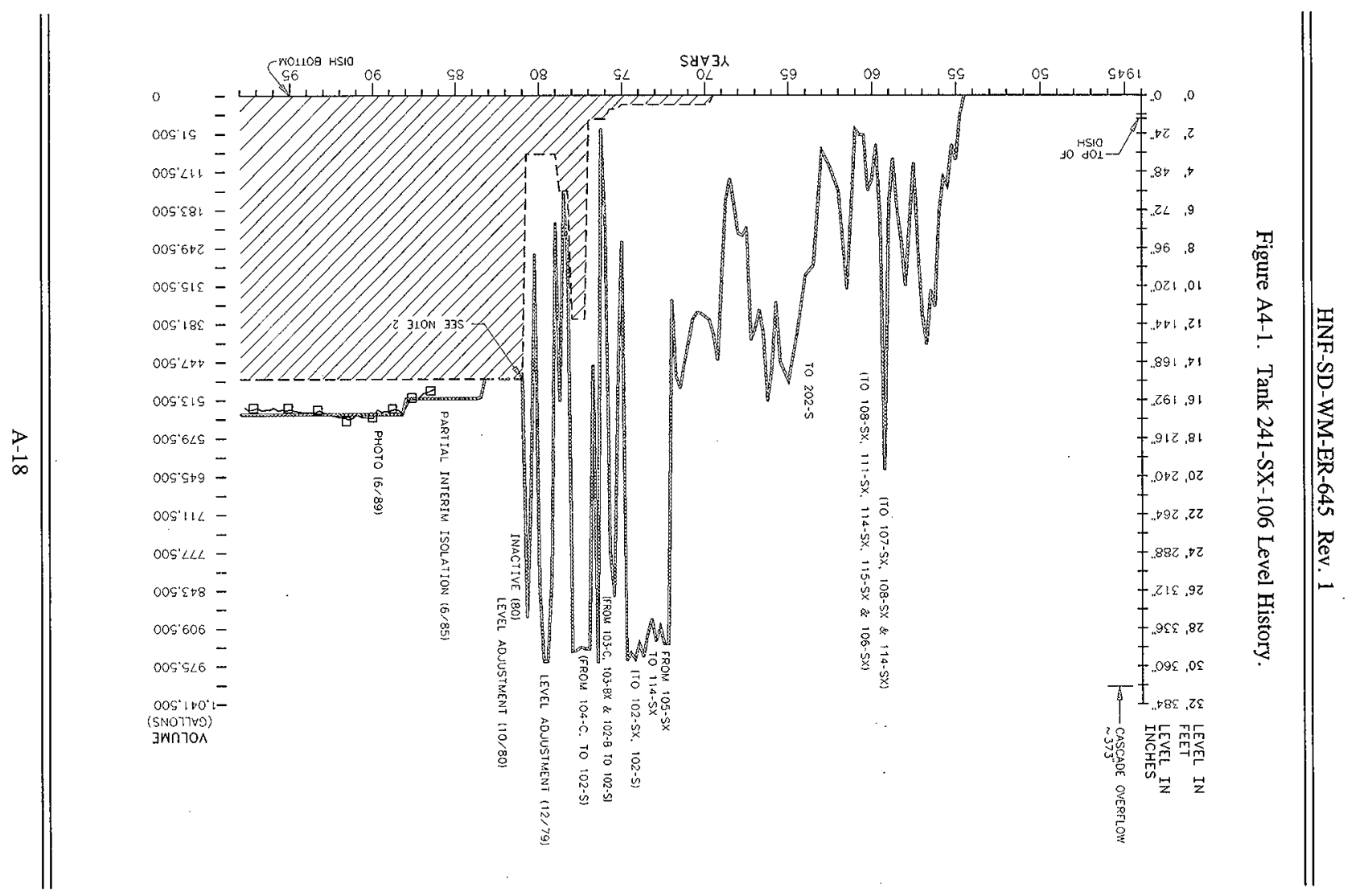


Figure A4-2. Tank 241-SX-106 High Temperature Plot.

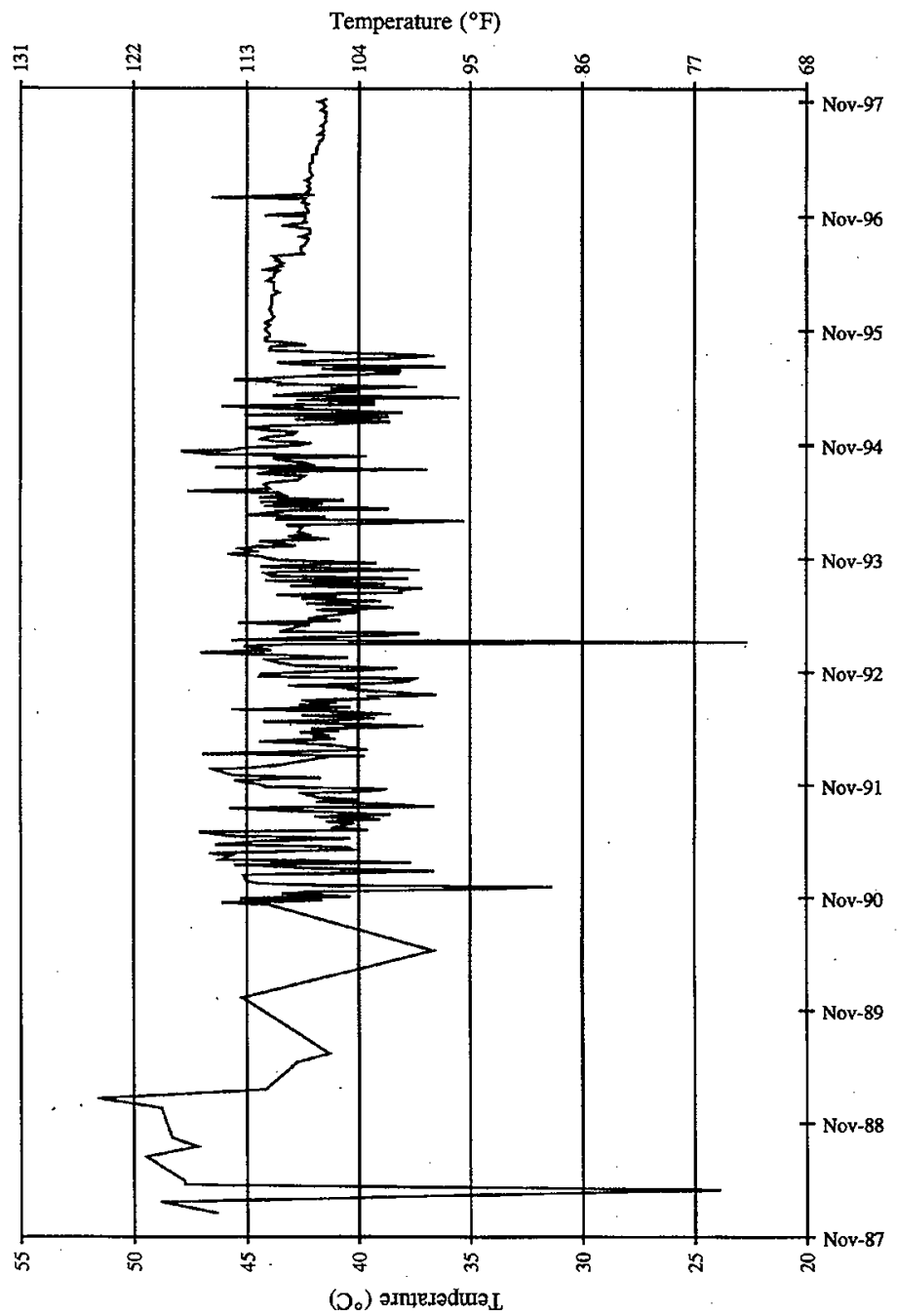




\section{A5.0 APPENDIX A REFERENCES}

Agnew, S. F., J. Boyer, R. A. Corbin, T. B. Duran, J. R. Fitzpatrick, K. A. Jurgensen, T. P. Ortiz, and B. L. Young, 1997b, Hanford Tank Chemical and Radionuclide Inventories: HDW Model Rev. 4, LA-UR-96-3860, Los Alamos National Laboratory, Los Alamos, New Mexico.

Agnew, S. F., R. A. Corbin, T. B. Duran, K. A. Jurgensen, T. P. Ortiz, and B. L. Young, 1997b, Waste Status and Transaction Record Summary (WSTRS) Rev. 4 , LA-UR-97-311, Los Alamos National Laboratory, Los Alamos, New Mexico.

Alstad, A. T., 1993, Riser Configuration Document for Single-Shell.Waste Tanks, WHC-SD-RE-TI-053, Rev. 9, Westinghouse Hanford Company, Richland, Washington.

Brevick, C. H., J. L. Stroup, and J. W. Funk, 1997, Supporting Document for the Historical Tank Content Estimate for SX-Tank Farm, WHC-SD-WM-ER-324, Rev. 1, Fluor Daniel Northwest, Inc., for Fluor Daniel Hanford, Inc., Richland, Washington.

Hanlon, B. M., 1998, Waste Tank Summary Report for Month Ending May 31, 1998, HNF-EP-0182-122, Lockheed Martin Hanford Corp. for Fluor Daniel Hanford, Inc., Richland, Washington.

Leach, C. E. and S. M. Stahl, 1997, Hanford Site Tank Farm Facilities Interim Safety Basis, WHC-SD-WM-ISB-001, Rev. OM, Lockheed Martin Hanford Corp. for Fluor Daniel Hanford, Inc., Richland, Washington.

Lipnicki, J., 1997, Waste Tank Risers Available for Sampling, HNF-SD-WM-TI-710, Rev. 4, Lockheed Martin Hanford Corp. for Fluor Daniel Hanford, Inc., Richland, Washington.

LMHC, 1998, SACS: Surveillance Analysis Computer System. In: SQLServer/Visual Basic, [Mainframe], Available: Hanford Local Area Network, Lockheed Martin Hanford Corp.Richland, Washington.

Public Law 101-510, 1990, "Safety Measures for Waste Tanks at Hanford Nuclear Reservation," Section 3137 of National Defense Authorization Act for Fiscal Year 1991.

Tran, T. T., 1993, Thermocouple Status Single-Shell \& Double-Shell Waste Tanks, WHC-SD-WM-TI-553, Rev. 0, Westinghouse Hanford Company, Richland, Washington.

Vitro, 1985, Piping Waste Tank Isolation 241-SX-106, H-2-73223, Rev. 2, Vitro Engineering Corporation, Richland, Washington. 
Wilkins, N. E., R. E. Bauer, and D. M. Ogden, 1997, Results of Vapor Space Monitoring of Flammable Gas Watch List Tanks, HNF-SD-WM-TI-797, Rev. 2, Lockheed Martin Hanford Corp. for Fluor Daniel Hanford, Inc., Richland, Washington. 
This page intentionally left blank. 
HNF-SD-WM-ER-645 Rev. 1

APPENDIX B

SAMPLING OF TANK 241-SX-106 
HNF-SD-WM-ER-645 Rev. 1

This page intentionally left blank. 


\section{APPENDIX B \\ SAMPLING OF TANK 241-SX-106}

Appendix B provides sampling and analysis information for each known sampling event for tank 241-SX-106 and assesses the push mode core sample results. It includes the following:

- Section B1.0: Tank Sampling Overview

- Section B2.0: Sampling Events

- Section B3.0: Assessment of Characterization Results

- Section B4.0: References for Appendix B.

\section{B1.0 TANK SAMPLING OVERVIEW}

Appendix B describes the sampling and analysis events for tank 241-SX-106. Push mode core samples were taken in October and December 1997 to satisfy the requirements of the Tank Safety Screening Data Quality Objective (Dukelow et al. 1995), Memorandum of Understanding for the Organic Complexant Safety Issue Data Requirements (Schreiber 1997), Data Quality Objective to Support Resolution of the Organic Solvent Safety Issue (Meacham et al. 1997), and Data Quality Objective to Support Resolution of the Flammable Gas Safety Issue (Bauer and Jackson 1998). The sampling and analyses were performed in accordance with the Tank 241-SX-106 Push Mode Core Sampling and Analysis Plan (Jo 1997). Further discussions of the sampling and analysis procedures can be found in the Tank Characterization Reference Guide (DeLorenzo et al. 1994). These analyses are discussed in Section B2.1.

The tank sampling and analysis plan also includes requirements to support the Sampling Plan for Tank 241-SX-106 Retained Gas Sampler Deployment (Bates 1997). These analyses are discussed in Section B2.2.

Tank headspace vapors were characterized from samples collected in March 1995 in accordance with the Tank 241-SX-106 Tank Characterization Plan (Homi 1995). These analyses are discussed in Section B2.3. 


\section{B2.0 SAMPLING EVENTS}

This section describes sampling events. The analytical results used to characterize current tank contents were derived from the 1995 vapor sample and 1997 push mode core sample. The analytical results from the 1997 core sample are shown in this section. The sampling and analytical requirements from the safety screening, flammable gas, organic complexant, and organic solvent DQOs are also summarized.

\section{B2.1 1997 CORE SAMPLING EVENT}

A vertical profile of the waste is used to satisfy the requirements of the safety screening DQO (Dukelow et al. 1995). Safety screening analyses include total alpha activity to determine criticality, DSC to ascertain the fuel energy value, and thermogravimetric analysis (TGA) to obtain the total moisture content. In addition, combustible gas meter readings in the tank headspace were performed to measure flammability. The safety screening DQO also requires bulk density measurements.

In accordance with Jo (1997), two core samples were to be obtained from tank 241-SX-106 risers 3 and 6 with 11 segments expected in each core. Cores 223 and 224 were obtained from risers 6 and 3 , respectively.

Core 223 consisted of 10 push mode core segments removed from tank 241-SX-106, riser 6 , between October 13 and October 30, 1997. Segments were received by the 222-S Laboratory between October 15 and November 7, 1997. Selected segments (6, 6A, and 9) were sampled using the RGS and extruded by the Chemistry, Analysis and Technical Support Group. Segment 11 was also sampled using the RGS; however, during retrieval the grapple cable broke, requiring the drill string and sampler to be removed manually. The $\mathrm{x}$-rays of the sampler indicated that it contained lithium bromide solution and air with no sample material present.

Core 224 consisted of eleven push mode core segments removed from tank 241-SX-106, riser 3, between December 2 and December 11, 1997. Segments were received by the 222-S Laboratory between December 3 and December 12, 1997. Selected segments $(2,4,7$, and 10) were sampled using the RGS and extruded by the Chemistry, Analysis and Technical Support Group.

A field blank was provided to the 222-S Laboratory with core 223 . It underwent the same analysis as the drainable liquid as instructed by Jo (1997). 
Lithium bromide-traced water was used to maintain back pressure on the drill string during sampling. Each sample segment underwent ICP analysis for lithium and ion chromatography (IC) analysis for bromide to determine how much, if any, external water may have entered the sample during sampling.

Table B2-1 summarizes the sampling and analytical requirements from the safety screening, flammable gas, organic complexant, and organic solvent DQOs.

Table B2-1. Integrated Data Quality Objective Requirements for Tank 241-SX-106. ${ }^{1}$

\begin{tabular}{|c|c|c|c|}
\hline Sarough & Moplowis bors & samplug requirenients & 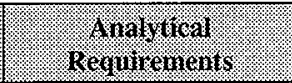 \\
\hline $\begin{array}{l}\text { Push mode } \\
\text { core } \\
\text { sampling }\end{array}$ & $\begin{array}{l}\text { Safety screening } \\
\text { - Energetics } \\
\text { - Moisture content } \\
\text { - Total alpha } \\
\text { - Flammable gas } \\
\text { Dukelow et al. (1995) } \\
\text { Flammable gas } \\
\text { Bauer and Jackson (1998) } \\
\text { Organic complexant } \\
\text { Schreiber (1997) }\end{array}$ & $\begin{array}{l}\text { Core samples from a } \\
\text { minimum of two risers } \\
\text { separated radially to the } \\
\text { maximum extent possible. } \\
\text { Combustible gas } \\
\text { measurement }\end{array}$ & $\begin{array}{l}\text { Flammability, } \\
\text { energetics, moisture, } \\
\text { total alpha activity, } \\
\text { density, anions, cations, } \\
\text { radionuclides, TOC, } \\
\text { separable organics, } \\
\text { physical properties, TIC }\end{array}$ \\
\hline $\begin{array}{l}\text { Vapor } \\
\text { sampling }\end{array}$ & $\begin{array}{l}\text { Organic solvent } \\
\text { Meacham et al. (1997) }\end{array}$ & $\begin{array}{l}\text { Steel canisters, triple } \\
\text { sorbent traps, sorbent trap } \\
\text { systems }\end{array}$ & $\begin{array}{l}\text { Flammable gas, organic } \\
\text { vapors, permanent gases }\end{array}$ \\
\hline
\end{tabular}

Note: 'Jo (1997)

\section{B2.1.1 Sample Handling}

The core samples were shipped to the 222-S Laboratory for subsampling and analysis. Samples were assigned laboratory numbers and were subjected to visual inspection for color, clarity, and solids content. The radiation dose rate on contact was also measured. Drainable liquid was collected and clarified by centrifugation. Segments containing solids were divided into upper and lower half segments and were also divided longitudinally to provide material for the gas bubble retention and release studies. 
The SAP (Jo 1997) states that the core samples should be transported to the laboratory within three calendar days from the time each segment is removed from the tank. This was not met for some segments from cores 223 and 224.

Sample extrusion and subsampling for the two cores are presented in Table B2-2.

Table B2-2. Tank 241-SX-106 Subsampling Scheme and Sample Description. ${ }^{1}$ (4 sheets)

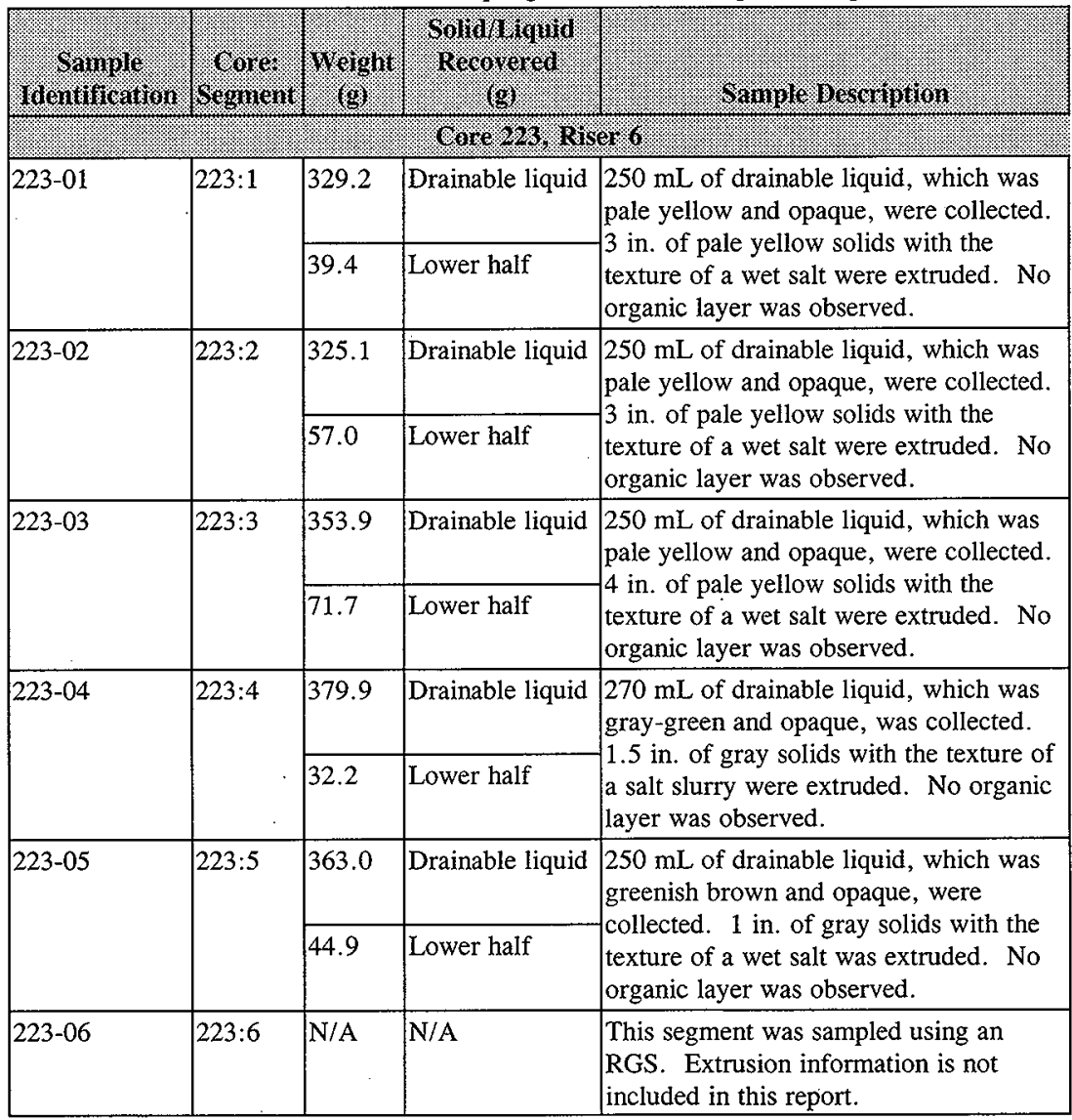


Table B2-2. Tank 241-SX-106 Subsampling Scheme and Sample Description. ${ }^{1}$ (4 sheets)

\begin{tabular}{|c|c|c|c|c|}
\hline Sample & Segrinert & 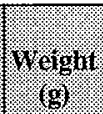 & 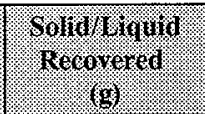 & Sample Description \\
\hline \multicolumn{5}{|c|}{ 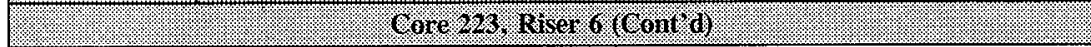 } \\
\hline $223-06 \mathrm{~A}$ & $223: 6 \mathrm{~A}$ & $\mathrm{~N} / \mathrm{A}$ & N/A & $\begin{array}{l}\text { This segment was sampled using an } \\
\text { RGS. Extrusion information is not } \\
\text { included in this report. }\end{array}$ \\
\hline \multirow[t]{2}{*}{ 223-07 } & \multirow[t]{2}{*}{$223: 7$} & 214.9 & Upper half & \multirow{2}{*}{$\begin{array}{l}\text { There was no drainable liquid. } 14 \text { in. of } \\
\text { black solids with the texture of a wet } \\
\text { sludge were extruded. Solids were } \\
\text { subsampled in half segments. }\end{array}$} \\
\hline & & 179.4 & Lower half & \\
\hline \multirow[t]{2}{*}{$223-08$} & \multirow[t]{2}{*}{$223: 8$} & 96.8 & Upper half & \multirow{2}{*}{$\begin{array}{l}\text { There was no drainable liquid. } 10 \text { in. of } \\
\text { solids were extruded. The upper } 2 \text { in. } \\
\text { were black with the texture of a wet } \\
\text { sludge. The lower } 8 \text { in. were dark grey } \\
\text { with the texture of a salt slurry. Solids } \\
\text { were subsampled in half segments. }\end{array}$} \\
\hline & & 245.3 & Lower half & \\
\hline $223-09$ & $223: 9$ & N/A & N/A & $\begin{array}{l}\text { This segment was sampled using an } \\
\text { RGS. Extrusion information is not } \\
\text { included in this report. X-rays show } \\
12.25 \text { in. of sample. }\end{array}$ \\
\hline \multirow[t]{2}{*}{$223-10$} & \multirow[t]{2}{*}{$223: 10$} & 235.1 & Upper half & \multirow{2}{*}{$\begin{array}{l}\text { There was no drainable liquid. } 11.5 \text { in. } \\
\text { of dark brown solids were extruded. } \\
\text { The upper } 9 \text { in. had the texture of a } \\
\text { moist salt. The lower } 2.5 \text { in. had the } \\
\text { texture of a salt slurry. Solids were } \\
\text { subsampled in half segments. }\end{array}$} \\
\hline & & 57.4 & Lower half & \\
\hline \multicolumn{5}{|c|}{ 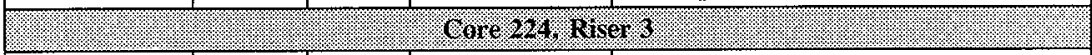 } \\
\hline \multirow[t]{2}{*}{$224-01$} & \multirow[t]{2}{*}{$224: 1$} & 356.0 & Drainable liquid & \multirow{2}{*}{$\begin{array}{l}250 \mathrm{~mL} \text { of drainable liquid, which was } \\
\text { pale yellow and opaque, were collected. } \\
3 \text { in. of white solids with the texture of a } \\
\text { salt slurry were extruded. No organic } \\
\text { layer was observed. }\end{array}$} \\
\hline & & 44.7 & Lower half & \\
\hline $224-02$ & $224: 2$ & N/A & N/A & $\begin{array}{l}\text { This segment was sampled using an } \\
\text { RGS. Extrusion information is not } \\
\text { included in this report. X-rays show } \\
19 \text { in. of sample. }\end{array}$ \\
\hline
\end{tabular}


Table B2-2. Tank 241-SX-106 Subsampling Scheme and Sample Description. ${ }^{1}$ (4 sheets)

\begin{tabular}{|c|c|c|c|c|}
\hline thentincation: & Segrinent & $\sqrt{\text { Vieighin }}$ & $\begin{array}{l}\text { Soliduligur } \\
\text { Recovered }\end{array}$ & (2) Sample Description: \\
\hline (3: & & \multicolumn{3}{|c|}{ Core 224. Riser 3 (Cont d) } \\
\hline \multirow[t]{2}{*}{ 224-03 } & \multirow[t]{2}{*}{$224: 3$} & 365.6 & Drainable liquid & \multirow{2}{*}{$\begin{array}{l}250 \mathrm{~mL} \text { of drainable liquid, which was } \\
\text { pale yellow and opaque, was collected. } \\
2 \text { in. of white solids with the texture of a } \\
\text { wet salt were extruded. No organic } \\
\text { layer was observed. }\end{array}$} \\
\hline & & 35.4 & Lower half & \\
\hline 224-04 & $224: 4$ & $\mathrm{~N} / \mathrm{A}$ & N/A & $\begin{array}{l}\text { This segment was sampled using an } \\
\text { RGS. Extrusion information is not } \\
\text { included in this report. }\end{array}$ \\
\hline \multirow[t]{4}{*}{ 224-05 } & \multirow[t]{4}{*}{$224: 5$} & 136.1 & Drainable liquid & \multirow{4}{*}{$\begin{array}{l}110 \mathrm{~mL} \text { of drainable liquid, which was } \\
\text { dark grey and opaque, were collected. } \\
14 \text { in. of solids were extruded. The } \\
\text { upper } 2 \text { in. were white with the texture } \\
\text { of a salt slurry. The lower } 12 \text { in. were } \\
\text { dark brown with the texture of a } \\
\text { salt/sludge slurry. No organic layer was } \\
\text { observed. }\end{array}$} \\
\hline & & & & \\
\hline & & 12.1 & Upper half & \\
\hline & & 262.6 & Lower half & \\
\hline \multirow[t]{3}{*}{$224-06$} & \multirow[t]{3}{*}{$224: 6$} & 79.3 & Drainable liquid & \multirow{3}{*}{$\begin{array}{l}55 \mathrm{~mL} \text { of drainable liquid, which was } \\
\text { dark grey and opaque. were collected. } \\
16 \text { in. of dark brown solids with the } \\
\text { texture of a salt/sludge slurry were } \\
\text { extruded. No organic layer was } \\
\text { observed. }\end{array}$} \\
\hline & & 167.2 & Upper half & \\
\hline & & 158.9 & Lower half & \\
\hline $224-07$ & $224: 7$ & N/A & N/A & $\begin{array}{l}\text { This segment was sampled using an } \\
\text { RGS. Extrusion information is not } \\
\text { included in this report. X-rays show } \\
13.5 \text { in. of sample. }\end{array}$ \\
\hline \multirow[t]{2}{*}{$224-08$} & \multirow[t]{2}{*}{$224: 8$} & 70.4 & Upper half & \multirow{2}{*}{$\begin{array}{l}\text { There was no drainable liquid. } 13 \text { in. of } \\
\text { dark grey solids with the texture of a wet } \\
\text { salt were extruded. Solids were } \\
\text { subsampled in half segments. }\end{array}$} \\
\hline & & 245.2 & Lower half & \\
\hline
\end{tabular}


Table B2-2. Tank 241-SX-106 Subsampling Scheme and Sample Description.' (4 sheets)

\begin{tabular}{|c|c|c|c|c|}
\hline Sormples: & Sorver: & 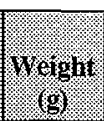 & 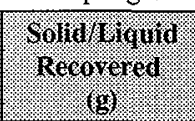 & Sinuple Bescription \\
\hline (2.1. & \multicolumn{4}{|c|}{ 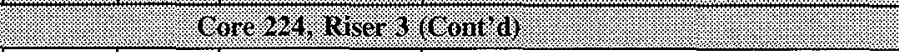 } \\
\hline \multirow[t]{2}{*}{ 224-09 } & \multirow[t]{2}{*}{$224: 9$} & 129.7 & Upper half & \multirow{2}{*}{$\begin{array}{l}\text { There was no drainable liquid. } 14.5 \text { in. } \\
\text { of dark grey solids were extruded. The } \\
\text { upper } 6 \text { in. had the texture of a wet salt. } \\
\text { The lower } 8.5 \text { in. had the texture of a } \\
\text { dry salt. Solids were subsampled in half } \\
\text { segments. }\end{array}$} \\
\hline & & 156.5 & Lower half & \\
\hline $224-10$ & $224: 10$ & N/A & N/A & $\begin{array}{l}\text { This segment was sampled using an } \\
\text { RGS. Extrusion information is not } \\
\text { included in this report. X-rays show } \\
13.5 \text { in. of sample. }\end{array}$ \\
\hline \multirow[t]{2}{*}{$224-11$} & \multirow[t]{2}{*}{$224: 11$} & 305.4 & Upper half & \multirow{2}{*}{$\begin{array}{l}\text { There was no drainable liquid. } 16 \text { in. of } \\
\text { dark grey solids with the texture of a wet } \\
\text { salt were extruded. Solids were } \\
\text { subsampled in half segments. }\end{array}$} \\
\hline & & 121.8 & Lower half & \\
\hline
\end{tabular}

Notes:

$\mathrm{N} / \mathrm{A}=$ This information was not available

'Steen (1998)

\section{B2.1.2 Sample Analysis}

The analyses performed on the segment core samples were those required by the safety screening, organic complexant, and flammable gas DQOs. The analyses required by the safety screening DQO included analyses for thermal properties by DSC, moisture content by TGA, content of fissile material by total alpha activity analysis, and bulk density. The safety screening DQO required ICP and IC analyses for lithium and bromide to assess the potential for hydrostatic head fluid contamination. The organic complexant DQO required analyses for TOC, thermal properties by DSC, and moisture content by TGA.

There was insufficient sample material from the core 224 , segment 6 , drainable liquid to perform the requested analyses.

All reported analyses were performed according to approved laboratory procedures (see Table B2-3). Table B2-4 is a summary of the sample portions, sample numbers, and analyses performed on each core sample. 
Table B2-3. Analytical Procedures. ${ }^{1}$

\begin{tabular}{|l|l|l|}
\hline \multicolumn{1}{|c|}{ Analysis } & \multicolumn{1}{|c|}{ Uethod } \\
\hline Energetics & Differential scanning calorimetry & LA-514-114 \\
\hline Percent water & Thermogravimetric analysis & LA-514-114 \\
\hline Bulk density & Gravimetry & LA-519-132 \\
\hline Specific gravity & Gravimetry & LA-510-112 \\
\hline Anions by IC & Ion chromatography & LA-533-105 \\
\hline ICP/AES analytes & $\begin{array}{l}\text { Inductively coupled plasma } \\
\text { spectrophotometry }\end{array}$ & LA-505-161 \\
\hline TIC/TOC & Persulfate oxidation/coulometry & LA-342-100 \\
\hline TOC & Furnace oxidation/coulometry & LA-344-105 \\
\hline Total alpha activity & Alpha proportional counter & LA-508-101 \\
\hline Flammable gas & Combustible gas analysis & IH 1.4 and IH $2.1^{2}$ \\
\hline
\end{tabular}

Notes:

AES $=$ atomic emission spectroscopy

${ }^{1}$ Steen (1998)

${ }^{2}$ WHC (1992)

Table B2-4. Tank 241-SX-106 Sample Analysis Summary. ${ }^{1}$ (6 sheets)

\begin{tabular}{|c|c|c|c|c|}
\hline Iriser & $\begin{array}{l}\text { Sample } \\
\text { Irenirication: }\end{array}$ & Sample I ontion & Sarnple Number & (2. Analyses \\
\hline \multirow[t]{10}{*}{6} & \multirow[t]{5}{*}{$\begin{array}{l}\text { Core } 223, \\
\text { segment } 1\end{array}$} & Drainable liquid & S97T002179 & $\begin{array}{l}\text { TIC/TOC, specific } \\
\text { gravity, ICP, IC, } \\
\text { DSC/TGA, alpha }\end{array}$ \\
\hline & & \multirow[t]{4}{*}{ Lower half } & S97T002175 & Bulk density \\
\hline & & & S97T002176 & TIC/TOC, DSC/TGA \\
\hline & & & S97T002177 & ICP, alpha \\
\hline & & & S97T002178 & IC \\
\hline & \multirow[t]{5}{*}{\begin{tabular}{|l} 
Core 223, \\
segment 2
\end{tabular}} & Drainable liquid & S97T002188 & $\begin{array}{l}\text { TIC/TOC, specific } \\
\text { gravity, ICP, IC, } \\
\text { DSC/TGA, alpha }\end{array}$ \\
\hline & & \multirow[t]{4}{*}{ Lower half } & S97T002182 & Bulk density \\
\hline & & & S97T002183 & TIC/TOC, DSC/TGA \\
\hline & & & S97T002185 & ICP, alpha \\
\hline & & & S97T002186 & IC \\
\hline
\end{tabular}


HNF-SD-WM-ER-645 Rev. 1

Table B2-4. Tank 241-SX-106 Sample Analysis Summary. ' (6 sheets)

\begin{tabular}{|c|c|c|c|c|}
\hline Riser. & Sample & Sample Portion & Sanple Yunber & in. \\
\hline \multirow[t]{25}{*}{6 (Cont'd) } & \multirow[t]{5}{*}{$\begin{array}{l}\text { Core } 223, \\
\text { segment } 3\end{array}$} & Drainable liquid & S97T002199 & $\begin{array}{l}\text { TIC/TOC, specific } \\
\text { gravity, ICP, IC, } \\
\text { DSC/TGA, alpha }\end{array}$ \\
\hline & & \multirow[t]{4}{*}{ Lower half } & S97T002190 & Bulk density \\
\hline & & & S97T002191 & TIC/TOC, DSC/TGA \\
\hline & & & S97T002194 & ICP, alpha \\
\hline & & & S97T002196 & IC \\
\hline & \multirow[t]{5}{*}{$\begin{array}{l}\text { Core } 223 \text {, } \\
\text { segment } 4\end{array}$} & Drainable liquid & S97T002200 & $\begin{array}{l}\text { TIC/TOC, specific } \\
\text { gravity, ICP, IC, } \\
\text { DSC/TGA, alpha }\end{array}$ \\
\hline & & \multirow[t]{4}{*}{ Lower half } & S97T002192 & TIC/TOC, DSC/TGA \\
\hline & & & S97T002193 & Bulk density \\
\hline & & & S97T002204 & ICP, alpha \\
\hline & & & S97T002205 & IC \\
\hline & \multirow[t]{5}{*}{$\begin{array}{l}\text { Core } 223 \text {, } \\
\text { segment } 5\end{array}$} & Drainable liquid & S97T002215 & $\begin{array}{l}\text { TIC/TOC, specific } \\
\text { gravity, ICP, IC, } \\
\text { DSC/TGA, alpha }\end{array}$ \\
\hline & & \multirow[t]{4}{*}{ Lower half } & S97T002217 & Bulk density \\
\hline & & & S97T002218 & TIC/TOC, DSC/TGA \\
\hline & & & S97T002231 & ICP, alpha \\
\hline & & & S97T002237 & IC \\
\hline & \multirow{5}{*}{$\begin{array}{l}\text { Core 223, } \\
\text { segment } 6\end{array}$} & \multirow[t]{5}{*}{ Whole } & S97T002236 & Bulk density \\
\hline & & & S98T000692 & TIC/TOC, DSC/TGA \\
\hline & & & S98T000694 & ICP, alpha \\
\hline & & & S98T000695 & ICP \\
\hline & & & S98T000696 & IC \\
\hline & \multirow{5}{*}{$\begin{array}{l}\text { Core 223, } \\
\text { segment } 6 \mathrm{~A}\end{array}$} & \multirow[t]{5}{*}{ Whole } & S97T002242 & Bulk density \\
\hline & & & S98T000697 & TIC/TOC, DSC/TGA \\
\hline & & & S98T000703 & ICP, alpha \\
\hline & & & S98T000705 & $\mathrm{ICP}$ \\
\hline & & & S98T000707 & IC \\
\hline
\end{tabular}


HNF-SD-WM-ER-645 Rev. 1

Table B2-4. Tank 241-SX-106 Sample Analysis Summary. ${ }^{1}$ (6 sheets)

\begin{tabular}{|c|c|c|c|c|}
\hline Riser: & $\begin{array}{l}\text { Samples } \\
\text { talentiflearion }\end{array}$ & Sample romitron & Sarmple Yunuber & Analoses \\
\hline \multirow[t]{26}{*}{6 (Cont'd) } & \multirow{7}{*}{$\begin{array}{l}\text { Core } 223, \\
\text { segment } 7\end{array}$} & \multirow[t]{3}{*}{ Upper half } & S97T002220 & TIC/TOC, DSC/TGA \\
\hline & & & S97T002233 & $\mathrm{ICP}$ \\
\hline & & & S97T002239 & IC \\
\hline & & \multirow[t]{4}{*}{ Lower half } & S97T002225 & Bulk density \\
\hline & & & S97T002226 & TIC/TOC, DSC/TGA \\
\hline & & & S97T002232 & ICP, alpha \\
\hline & & & S97T002238 & $\mathrm{IC}$ \\
\hline & \multirow{7}{*}{$\begin{array}{l}\text { Core } 223, \\
\text { segment } 8\end{array}$} & \multirow[t]{3}{*}{ Upper half } & S97T002223 & TIC/TOC, DSC/TGA \\
\hline & & & S97T002235 & ICP \\
\hline & & & S97T002241 & IC \\
\hline & & \multirow[t]{4}{*}{ Lower half } & S97T002228 & Bulk density \\
\hline & & & S97T002229 & TIC/TOC, DSC/TGA \\
\hline & & & S97T002234 & ICP, alpha \\
\hline & & & S97T002240 & $\mathrm{IC}$ \\
\hline & \multirow{5}{*}{$\begin{array}{l}\text { Core } 223, \\
\text { segment } 9\end{array}$} & \multirow[t]{5}{*}{ Whole } & S97T002251 & Bulk density \\
\hline & & & S98T000698 & TIC/TOC, DSC/TGA \\
\hline & & & S98T000704 & ICP, alpha \\
\hline & & & S98T000706 & ICP \\
\hline & & & S98T000708 & IC \\
\hline & \multirow{7}{*}{$\begin{array}{l}\text { Core } 223, \\
\text { segment } 10\end{array}$} & \multirow[t]{3}{*}{ Upper half } & S97T002262 & TIC/TOC, DSC/TGA \\
\hline & & & S97T002265 & $\mathrm{ICP}$ \\
\hline & & & S97T002266 & IC \\
\hline & & \multirow[t]{4}{*}{ Lower half } & S97T002258 & Bulk density \\
\hline & & & S97T002259 & TIC/TOC, DSC/TGA \\
\hline & & & S97T002263 & ICP, alpha \\
\hline & & & S97T002264 & IC \\
\hline
\end{tabular}


HNF-SD-WM-ER-645 Rev. 1

Table B2-4. Tank 241-SX-106 Sample Analysis Summary. ${ }^{1}$ (6 sheets)

\begin{tabular}{|c|c|c|c|c|}
\hline Miser & 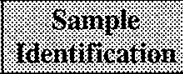 & Sample pomiran & 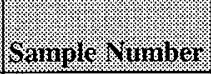 & Analyses \\
\hline \multirow[t]{20}{*}{3} & \multirow[t]{5}{*}{$\begin{array}{l}\text { Core } 224 \text {, } \\
\text { segment } 1\end{array}$} & Drainable liquid & S97T002323 & $\begin{array}{l}\text { TIC/TOC, specific } \\
\text { gravity, ICP, IC, } \\
\text { DSC/TGA }\end{array}$ \\
\hline & & \multirow[t]{4}{*}{ Lower half } & S97T002317 & Bulk density \\
\hline & & & S97T002318 & TIC/TOC, DSC/TGA \\
\hline & & & S97T002320 & ICP, alpha \\
\hline & & & S97T002321 & IC \\
\hline & \multirow{5}{*}{$\begin{array}{l}\text { Core } 224, \\
\text { segment } 2\end{array}$} & \multirow[t]{5}{*}{ Whole } & \$97T002310 & Bulk density \\
\hline & & & \$98T000709 & TIC/TOC, DSC/TGA \\
\hline & & & S98T000717 & ICP, alpha \\
\hline & & & S98T000721 & ICP \\
\hline & & & \$98T000725 & IC \\
\hline & \multirow[t]{5}{*}{$\begin{array}{l}\text { Core } 224, \\
\text { segment } 3\end{array}$} & Drainable liquid & S97T002371 & $\begin{array}{l}\text { TIC/TOC, specific } \\
\text { gravity, ICP, IC, } \\
\text { DSC/TGA }\end{array}$ \\
\hline & & \multirow[t]{4}{*}{ Lower half } & \$97T002331 & Bulk density \\
\hline & & & S97T002333 & TIC/TOC, DSC/TGA \\
\hline & & & S97T002334 & ICP, alpha \\
\hline & & & S97T002335 & IC \\
\hline & \multirow{5}{*}{$\begin{array}{l}\text { Core } 224, \\
\text { segment } 4\end{array}$} & \multirow[t]{5}{*}{ Whole } & S97T002327 & Bulk density \\
\hline & & & S98T000710 & TIC/TOC, DSC/TGA \\
\hline & & & S98T000718 & ICP, alpha \\
\hline & & & \$98T000722 & ICP \\
\hline & & & S98T000726 & IC \\
\hline
\end{tabular}


HNF-SD-WM-ER-645 Rev. 1

Table B2-4. Tank 241-SX-106 Sample Analysis Summary. ${ }^{1}$ (6 sheets)

\begin{tabular}{|c|c|c|c|c|}
\hline Riser & $\begin{array}{l}\text { Sampie } \\
\text { ruentifieation }\end{array}$ & Sample Pontion & Sarinle Y Ymber & Inalyses. \\
\hline \multirow[t]{27}{*}{3 (Cont'd) } & \multirow[t]{8}{*}{$\begin{array}{l}\text { Core } 224, \\
\text { segment } 5\end{array}$} & Drainable liquid & S97T002372 & $\begin{array}{l}\text { TIC/TOC, specific } \\
\text { gravity, ICP, IC, } \\
\text { DSC/TGA }\end{array}$ \\
\hline & & \multirow[t]{3}{*}{ Upper half } & S97T002348 & TIC/TOC, DSC/TGA \\
\hline & & & S97T002354 & IC \\
\hline & & & S97T002360 & ICP \\
\hline & & \multirow[t]{4}{*}{ Lower half } & S97T002336 & Bulk density \\
\hline & & & S97T002347 & TIC/TOC, DSC/TGA \\
\hline & & & S97T002353 & IC \\
\hline & & & S97T002359 & ICP, alpha \\
\hline & \multirow{7}{*}{$\begin{array}{l}\text { Core } 224, \\
\text { segment } 6\end{array}$} & \multirow[t]{3}{*}{ Upper half } & S97T002350 & TIC/TOC, DSC/TGA \\
\hline & & & S97T002356 & IC \\
\hline & & & S97T002362 & ICP \\
\hline & & \multirow[t]{4}{*}{ Lower half } & S97T002338 & Bulk density \\
\hline & & & S97T002349 & TIC/TOC, DSC/TGA \\
\hline & & & S97T002355 & IC \\
\hline & & & S97T002361 & ICP, alpha \\
\hline & \multirow{5}{*}{$\begin{array}{l}\text { Core } 224, \\
\text { segment } 7\end{array}$} & \multirow[t]{5}{*}{ Whole } & S97T002374 & Bulk density \\
\hline & & & S98T000711 & TIC/TOC, DSC/TGA \\
\hline & & & S98T000719 & ICP, alpha \\
\hline & & & S98T000723 & ICP \\
\hline & & & S98T000727 & IC \\
\hline & \multirow{7}{*}{$\begin{array}{l}\text { Core } 224, \\
\text { segment } 8\end{array}$} & \multirow[t]{3}{*}{ Upper half } & S97T002352 & TIC/TOC, DSC/TGA \\
\hline & & & S97T002358 & IC \\
\hline & & & S97T002364 & ICP \\
\hline & & \multirow[t]{4}{*}{ Lower half } & S97T002340 & Bulk density \\
\hline & & & S97T002351 & TIC/TOC, DSC/TGA \\
\hline & & & S97T002357 & IC \\
\hline & & & S97T002363 & ICP, alpha \\
\hline
\end{tabular}


Table B2-4. Tank 241-SX-106 Sample Analysis Summary. ${ }^{1}$ (6 sheets)

\begin{tabular}{|c|c|c|c|c|}
\hline Riser. & Sample & Sarivile romirien & Saniple Nunilon & Inal ises : \\
\hline \multirow[t]{19}{*}{3 (Cont'd) } & \multirow{7}{*}{$\begin{array}{l}\text { Core } 224 \\
\text { segment } 9\end{array}$} & \multirow[t]{3}{*}{ Upper half } & S97T002390 & TIC/TOC, DSC/TGA \\
\hline & & & S97T002392 & ICP \\
\hline & & & S97T002393 & IC \\
\hline & & \multirow[t]{4}{*}{ Lower half } & S97T002384 & Bulk density \\
\hline & & & S97T002385 & TIC/TOC, DSC/TGA \\
\hline & & & S97T002387 & ICP, alpha \\
\hline & & & S97T002388 & $\mathrm{IC}$ \\
\hline & \multirow{5}{*}{$\begin{array}{l}\text { Core } 224, \\
\text { segment } 10\end{array}$} & \multirow[t]{5}{*}{ Whole } & S97T002376 & Bulk density \\
\hline & & & S98T000712 & TIC/TOC, DSC/TGA \\
\hline & & & S98T000720 & ICP, alpha \\
\hline & & & S98T000724 & ICP \\
\hline & & & S98T000728 & $\mathrm{IC}$ \\
\hline & \multirow{7}{*}{$\begin{array}{l}\text { Core } 224, \\
\text { segment } 11\end{array}$} & \multirow[t]{3}{*}{ Upper Sample } & S97T002400 & TIC/TOC, DSC/TGA \\
\hline & & & S97T002402 & $\mathrm{ICP}$ \\
\hline & & & S97T002403 & IC, TOC \\
\hline & & \multirow[t]{4}{*}{ Lower half } & S97T002394 & Bulk density \\
\hline & & & S97T002395 & TIC/TOC, DSC/TGA \\
\hline & & & S97T002397 & ICP, alpha \\
\hline & & & S97T002398 & IC \\
\hline
\end{tabular}

Note:

'Steen (1998)

\section{B2.1.3 Analytical Results}

This section summarizes the sampling and analytical results associated with the October through December 1997 sampling and analysis of tank 241-SX-106. Table B2-5 indicates which summary result tables are associated with the total alpha activity, percent water, energetics, IC, ICP, and TOC analytical results. These results are documented in Steen (1998). 
Table B2-5. Analytical Tables.

\begin{tabular}{|l|l|}
\hline \multicolumn{1}{|c|}{ Mnalysis } & \multicolumn{1}{|c|}{ Table Number } \\
\hline ICP/emission spectroscopy & B2-9 through B2-45 \\
\hline IC & B2-46 through B2-53 \\
\hline TIC & B2-54 \\
\hline TOC by persulfate & B2-55 \\
\hline TOC by furnace oxidation & B2-56 \\
\hline Total alpha & B2-57 \\
\hline Energetics by DSC & B2-58 and B2-59 \\
\hline Percent water by TGA & B2-60 \\
\hline Bulk density & B2-61 \\
\hline Specific gravity & B2-62 \\
\hline
\end{tabular}

The quality control parameters assessed in conjunction with tank 241-SX-106 samples were standard recoveries, spike recoveries, duplicate analyses (relative percent differences [RPDs]), and blanks. The quality control criteria are specified in the SAP (Jo 1997). The limits for blanks are set forth in guidelines followed by the laboratory, and all data results in this report have met those guidelines. Sample and duplicate pairs, in which any quality control parameter was outside these limits, are footnoted in the sample mean column of the following data summary tables with an a, b, c, d, e, f, g, and h as follows:

- "a" indicates the standard recovery was below the quality control limit

- "b" indicates the standard recovery was above the quality control limit

- "c" indicates the spike recovery was below the quality control limit

- "d" indicates the spike recovery was above the quality control limit

- " $e$ " indicates the RPD was greater than the quality control limit range

- " $f$ " indicates that there was blank contamination

- " $\mathrm{g}$ " indicates that this is a tentatively identified compound

- " $h$ " indicates that the serial dilution exceeds the acceptance limit.

In the analytical tables in this section, the "mean" is the average of the result and duplicate value. All values, including those below the detection level (denoted by " $<$ ") were averaged. If both sample and duplicate values were nondetected or if one value was detected while the other was not, the mean is expressed as a nondetected value. If both values were detected, the mean is expressed as a detected value. 
B2.1.3.1 Inductively Coupled Plasma. Analyses by ICP were performed in duplicate on all samples. The analyses were performed directly on the drainable liquid samples following an acid dilution. The solid samples were analyzed following a potassium hydroxide fusion digestion in a nickel crucible. In addition, the solid subsamples from the RGS segments were prepared for analysis by acid digestion. Although a full suite of analytes were reported, only lithium was specifically requested by the safety screening DQO to correct potentially compromised percent water measurements.

The primary ICP analytes detected were aluminum, iron, sodium, and zirconium. Lithium values were below detection levels. This suggests that hydrostatic head fluid contamination was not a problem.

B2.1.3.2 Ion Chromatography (Ions). The analyses for IC were performed in duplicate on all samples. The analyses were performed directly on the drainable liquid samples. The solid samples were analyzed following a water digestion. Although a full suite of analytes were reported, only bromide was specifically requested by the safety screening DQO to correct potentially compromised percent water measurements.

The primary IC analytes detected were nitrate, nitrite, and phosphate. With the exception of a few segments, the majority of the bromide values were below detection levels.

B2.1.3.3 Total Inorganic Carbon. The analyses for TIC by persulfate/coulometry were performed in duplicate directly on all samples. The solid mean results ranged from $1,530 \mu \mathrm{g} \mathrm{C} / \mathrm{g}$ to $10,200 \mu \mathrm{g} \mathrm{C} / \mathrm{g}$. The liquid mean results ranged from $4,760 \mu \mathrm{g} \mathrm{C} / \mathrm{mL}$ to $5,500 \mu \mathrm{g} \mathrm{C} / \mathrm{mL}$.

B2.1.3.4 Total Organic Carbon. The analyses for TOC by persulfate/coulometry were performed in duplicate directly on all samples. None of the results exceeded the TOC notification limit of 3 weight percent (dry weight). The solid mean results ranged from $1,230 \mu \mathrm{g} \mathrm{C} / \mathrm{g}$ to $6,410 \mu \mathrm{g} \mathrm{C} / \mathrm{g}$. The liquid mean results ranged from $3,850 \mu \mathrm{g} \mathrm{C} / \mathrm{mL}$ to $4,500 \mu \mathrm{g} \mathrm{C} / \mathrm{mL}$.

The analyses for TOC by furnace oxidation/coulometry were required as a secondary analysis for those samples that exhibited exothermic energy, and the persulfate TOC did not account for 75 percent of the exothermic energy. The core 224, segment 11 , upper half, solid sample was analyzed following a water digestion. The results did not exceed the TOC notification limit of 3 wt weight percent (dry weight).

B2.1.3.5 Total Alpha Activity. Analyses for total alpha activity were performed in duplicate directly on the drainable liquids. The centrifuged solid samples were analyzed in duplicate following a fusion digestion. All liquid total alpha results were below the total alpha activity action limit of $61.5 \mu \mathrm{Ci} / \mathrm{mL}$. All solid total alpha results were below the total alpha activity action limit of $34.4 \mu \mathrm{Ci} / \mathrm{g}$. The highest results returned were $0.0038 \mu \mathrm{Ci} / \mathrm{mL}$ for the liquid samples and $1.26 \mu \mathrm{Ci} / \mathrm{g}$ for the solid samples. 
B2.1.3.6 Differential Scanning Calorimetry. In a DSC analysis, heat absorbed or emitted by a substance is measured while the sample is heated at a constant rate. Nitrogen is passed over the sample material to remove any gases being released. The onset temperature for an endothermic or exothermic event is determined graphically. The analyses for exothermic energy by DSC were performed in duplicate directly on the samples.

All DSC results were below the action limit of $480 \mathrm{~J} / \mathrm{g}$ dry weight. The highest result returned was $269 \mathrm{~J} / \mathrm{g}$ dry weight (core 224, segment 11 , upper half).

B2.1.3.7 Thermogravimetric Analysis. Thermogravimetric analysis measures the mass of a sample as its temperature is increased at a constant rate. Nitrogen is passed over the sample during heating to remove any released gases. Any decrease in the weight of a sample during TGA represents a loss of gaseous matter from the sample, through evaporation or through a reaction that forms gas phase products. The moisture content is estimated by assuming that all TGA sample weight loss up to a certain temperature (typically 150 to $200^{\circ} \mathrm{C}$ [300 to $390{ }^{\circ} \mathrm{F}$ ) is caused by water evaporation. The temperature limit for moisture loss is chosen by the operator at an inflection point on the TGA plot. Other volatile matter fractions can often be differentiated by inflection points as well.

The analyses for moisture content by TGA were performed in duplicate directly on all samples. TGA results were determined by summing the weight loss steps that occurred below $250^{\circ} \mathrm{C}\left(482^{\circ} \mathrm{F}\right)$; weight loss steps above this temperature were not used to determine the result. The percent water for tank 241-SX-106 samples ranged from 22.3 to 69.9 percent for the solid samples and 20.9 to 51.5 percent for the liquid samples.

B2.1.3.8 Bulk Density and Specific Gravity. Bulk density was performed directly on the solid samples. The results of the bulk density measurements ranged from $1.24 \mathrm{~g} / \mathrm{mL}$ to $1.79 \mathrm{~g} / \mathrm{mL}$.

Specific gravity was performed in duplicate directly on the drainable liquid samples. The results of the specific gravity measurements ranged from 1.40 to 1.45 (mean specific gravity was 1.42).

\section{B2.2 RETAINED GAS SAMPLER RESULTS}

Results of the retained gas analyses were presented in Mahoney et al. (1998). The RGS is a modified version of the core sampler used at the Hanford Site. It is designed to be used with the gas extraction equipment in the hot cell to capture and extrude a gas-containing waste sample in a hermetically sealed system. The retained gases are then extracted and stored in small gas canisters. The composition of the gases contained in the canisters is measured by mass spectroscopy. The total gas volume in the sample is obtained from analyzing the extraction process. 
The retained gas inventories calculated from the local measurements of gas volume fraction made by the RGS can differ significantly from the total gas inventories estimated by the barometric pressure effect (BPE) or surface level rise methods. These discrepancies occur together with irregular waste layers and other strong indications of lateral inhomogeneity in the waste. Because the retained gas samples are localized, they capture little of this variation. Therefore, the BPE or surface level rise methods, which are related to the overall gas in the tank, must be used to supplement RGS measurements in estimating the gas inventories.

In tank 241-SX-106, the waste consisted of two distinct layers: an upper liquid layer $193 \mathrm{~cm}$ (76 in.) in thickness and a lower, high-solids, saltcake layer $333 \mathrm{~cm}$ (131 in.) in thickness. There was also a thin, dry saltcake crust on the surface of the liquid.

The RGS was used in risers 3 and 6 to sample seven segments. Both risers are near the tank center. Four retained gas samples were obtained from the solids layer and two from the liquid layer. The sample from riser 6 , segment $6(6: 6)$ was taken by "slurping" the waste into the sampler (sucking the waste in by pressure differential without moving the sampler down through the waste). Subsequently, segment $6 \mathrm{~A}$ was taken in the same location. While sampling riser 3 , segment $10(3: 10)$, the piston was not pulled back as the sampler was pushed in, so the drill string was retracted and the procedure repeated correctly. All three of these samples should be considered as having been taken from disturbed waste and may not be comparable with other samples. While retrieving riser 6 , segment $11(6: 11)$ the grapple cable broke, so the drill string and sampler had to be removed manually. The $x$-rays of the sampler indicated that it contained lithium bromide solution and air with no sample material present. No retake was requested.

Retained gas measurements showed the insoluble retained gases in tank 241-SX-106 had an average composition of $19 \mathrm{~mol} \%$ nitrogen, $47 \mathrm{~mol} \%$ hydrogen, $22 \mathrm{~mol} \%$ nitrous oxide, and $11 \mathrm{~mol} \%$ ammonia. The remainder of the gas content was comprised of methane and other hydrocarbons. The measured ammonia levels were unusually high, averaging between 30,000 and $130,000 \mu \mathrm{mol} / \mathrm{L}$ of waste $\left(0.35\right.$ weight percent $\mathrm{NH}_{3}$ in the liquid). The samples retained void fractions between 0.095 and 0.37 , with much of the high-solids layer showing gas volume fractions greater than 0.30 .

The average gas volume fraction in the 241-SX-106 solids layer, based on RGS data, is $0.28 \pm 0.14$. The total in situ gas inventory, based on this gas volume fraction plus the tiny amount of gas in the supernatant layer, corresponds to $360 \pm 180 \mathrm{~m}^{3}$. The in situ gas volume calculated from waste level and barometric pressure data is $190 \pm 30 \mathrm{~m}^{3}$ (Whitney at al. 1997). The surface level rise can also be considered as a measure of retained gas volume: the waste surface has risen a net $46 \mathrm{~cm}$ (18 in.) since 1981 . This rise corresponds to an in situ gas accumulation of $190 \mathrm{~m}^{3}\left(6,600 \mathrm{ft}^{3}\right)$, which is consistent with the volume derived by the BPE method.

Because the RGS samples were taken from only four locations in the solids layer and the waste characteristics vary between the risers, the best estimate of the total gas inventory was 
considered to be that based on the BPE method. The BPE provides a global tank estimate of the retained gases, whereas the RGS method is localized to the sampling points. Additionally, the presence of a liquid layer covered by only a thin crust makes the waste level a very good indicator of the total gas inventory of the tank.

Table B2-6 contains the composition of the gas/vapor phase in each sample and the integrated average composition of retained gas in tank 241-SX-106. Sample 6:6A was not included because it was the second sampling attempt in the same location.

Table B2-6. Sample and Overall Average Compositions of Retained Gas with Gas Contamination Correction. ${ }^{1}$

\begin{tabular}{|c|c|c|c|c|c|}
\hline Risert. Seginent & $(\mathrm{N}, \mathrm{n} \%$ & 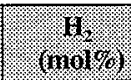 & N.0 & (nol\% & $\begin{array}{l}\text { Oaner } \\
\text { (niol\%) }\end{array}$ \\
\hline $6: 6$ & $23 \pm 3.2$ & $49 \pm 5.9$ & $17 \pm 2.6$ & $8.5 \pm 2.0$ & $2.7 \pm 1.6$ \\
\hline $6: 9$ & $17 \pm 2.1$ & $57 \pm 5.1$ & $16 \pm 1.5$ & $9.4 \pm 4.2$ & $0.6 \pm 0.3$ \\
\hline $3: 2$ & $62 \pm 13.0$ & $21 \pm 3.3$ & $12 \pm 1.9$ & $0.96 \pm 0.28$ & $3.3 \pm 1.6$ \\
\hline $3: 4$ & $64 \pm 50.0$ & $19 \pm 9.6$ & $14 \pm 7.9$ & $0.82 \pm 0.54$ & $1.9 \pm 1.2$ \\
\hline $3: 7$ & $17 \pm 5.8$ & $44 \pm 12.0$ & $25 \pm 11.0$ & $13 \pm 13.0$ & $0.7 \pm 0.3$ \\
\hline 3:10 & $20 \pm 4.1$ & $41+5.1$ & $26 \pm 3.3$ & $12+6.3$ & $0.9 \pm 0.2$ \\
\hline $\begin{array}{l}\text { Average in the } \\
\text { supernatant }^{2}\end{array}$ & $63 \pm 36.0$ & $20 \pm 7.3$ & $13 \pm 5.3$ & $0.88 \pm 0.43$ & $2.4 \pm 1.3$ \\
\hline $\begin{array}{l}\text { Average in the solids } \\
\text { layer }^{2}\end{array}$ & $19 \pm 3.2$ & $47 \pm 3.8$ & $22 \pm 3.3$ & $11 \pm 1.7$ & $0.9 \pm 0.3$ \\
\hline
\end{tabular}

Notes:

${ }^{1}$ Mahoney et al. (1998)

${ }^{2} T$ The error bands on the average composition, as for the individual sample compositions, only represent the instrument error resulting from not having enough samples to define the spatial variability of gas concentration.

\section{B2.3 VAPOR PHASE MEASUREMENT}

Vapor sampling and combustible gas testing were completed on March 24, 1995, to support the hazardous vapor safety screening DQO (Osborne and Buckley 1995). Results are shown in Tables B2-7 and B2-8.

In addition to the 1995 samples, headspace combustible gas measurements were obtained before the 1997 push mode core sampling of tank 241-SX-106. These measurements were 
taken to determine the LFL for the tank headspace at the time of sampling and to ensure safe operating conditions during sampling. A high LFL ( $>25$ percent) was recorded in the drill string after retrieving segment 9 . The drill string was purged using argon gas, and sampling resumed. Results of vapor phase measurements taken in the headspace of the tank are summarized in Table B2-7.

Table B2-7. Results of Headspace Measurements of Tank 241-SX-106.

\begin{tabular}{|c|c|c|}
\hline . Measurement & Mroll 24, $199 \%$ & (october 18.1999 \\
\hline LFL & $0.0 \%$ & $0.0 \%$ \\
\hline Ammonia & $150 \mathrm{ppmv}$ & $5.0 \mathrm{ppmv}$ \\
\hline Oxygen & $21.0 \%$ & $20.9 \%$ \\
\hline TOC & $5.5 \mathrm{ppmv}$ & $0.0 \mathrm{ppmv}$ \\
\hline
\end{tabular}

Note:

'Caprio (1995)

Table B2-8. Results of March 24, 1995, Headspace Vapor Sample Analysis. ${ }^{1}$ (2 sheets)

\begin{tabular}{|c|c|c|c|c|}
\hline Yatesory & Sanple Medrin & Arallye & Jonrenir mation & Vors \\
\hline \multirow[t]{4}{*}{ Inorganic analytes } & \multirow[t]{4}{*}{ Sorbent traps } & $\mathrm{NH}_{3}$ & $179.0 \pm 5.0$ & ppmv \\
\hline & & $\mathrm{NO}_{2}$ & $\leq 0.02$ & ppmv \\
\hline & & NO & $\leq 0.02$ & ppmv \\
\hline & & $\mathrm{H}_{2} \mathrm{O}$ & $14.9 \pm 0.07$ & $\mathrm{mg} / \mathrm{L}$ \\
\hline \multirow[t]{4}{*}{ Permanent gases } & \multirow{4}{*}{$\begin{array}{l}\text { SUMMA }^{\mathrm{TM}} \\
\text { canister }\end{array}$} & $\mathrm{H}_{2}$ & $<98.0$ & ppmv \\
\hline & & $\mathrm{CO}_{2}$ & $107.0 \pm 3.0$ & ppmv \\
\hline & & $\mathrm{CO}$ & $<12.0$ & ppmv \\
\hline & & $\mathrm{N}_{2} \mathrm{O}$ & 14.0 & ppmv \\
\hline
\end{tabular}


Table B2-8. Results of March 24, 1995, Headspace Vapor Sample Analysis. ${ }^{1}$ (2 sheets)

\begin{tabular}{|c|c|c|c|c|}
\hline (rategory) & 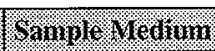 & 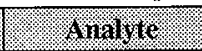 & 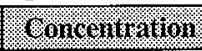 & Orits \\
\hline \multirow[t]{8}{*}{ Organics } & \multirow{5}{*}{$\begin{array}{l}\text { SUMMA }^{\mathrm{TM}} \\
\text { canister }\end{array}$} & Acetone & $0.021+0.001$ & ppmv \\
\hline & & 1-Propanol & $0.041 \pm 0.036$ & ppmv \\
\hline & & Tetrahydrofuran & $0.007 \pm 0.0003$ & ppmv \\
\hline & & Pyridine & $0.015 \pm 0.012$ & ppmv \\
\hline & & Methane & $<12.0$ & ppmv \\
\hline & \multirow[t]{3}{*}{ Sorbent traps } & Acetonitrile & $0.018 \pm 0.001$ & ppmv \\
\hline & & Acetone & $0.012 \pm 0.002$ & ppmv \\
\hline & & $\begin{array}{l}\text { Vinylidene } \\
\text { chloride }\end{array}$ & $0.0050 \pm 0.0036$ & ppmv \\
\hline
\end{tabular}

Notes:

'Huckaby and Bratzel (1995)

${ }^{2}$ At 990 mbar $(0.977 \mathrm{arm})$ and $30^{\circ} \mathrm{C}\left(86^{\circ} \mathrm{F}\right)$

\section{B2.3.1 Standard Hydrogen Monitoring System Results}

Gas monitoring of the tank headspace is accomplished through the use of the SHMS and vapor grab samples. Continuously hydrogen measurements are taken through the Whittaker electrochemical cell, which is hydrogen specific. The maximum hydrogen concentration measured by the SHMS was 330 ppmv on December 12, 1995 (Wilkins et al. 1997). Vapor grab samples are taken periodically to confirm the SHMS hydrogen readings and to obtain additional information about other gases in the tank. The other gases measured are nitrous oxide, which is an oxidizer, and methane, which is flammable. The average hydrogen concentration between August 25,1995, and May 20, 1998 was 43.4 ppmv, the minimum was $8 \mathrm{ppmv}$, and the maximum was $160 \mathrm{ppmv}$. The average methane concentration was 2.75 ppmv, and the average nitrous oxide concentrations was 28.7 ppmv.

\section{B2.4 DESCRIPTION OF HISTORICAL SAMPLING EVENTS}

Analyses of sampling events for tank 241-SX-106 were obtained from historical records. Several grab samples were obtained from tank 241-SX-106 between December 1974 and November 1979 in support of process engineering operations. Supernatant and evaporator feed were removed from tank 241-SX-106 from 1978 to 1980 , and the tank received evaporator bottoms and evaporator feed. As a result, pre-1980 samples do not represent current tank contents and are not included in this report. Reference to these historical sampling events can be found in Appendix E. 


\section{PUSH CORE DATA TABLES}

Table B2-9. Tank 241-SX-106 Analytical Results: Aluminum (ICP). (2 sheets)

\begin{tabular}{|c|c|c|c|c|c|}
\hline $\begin{array}{l}\text { Sample } \\
\text { Number }\end{array}$ & $\begin{array}{l}\text { Sample } \\
\text { Lacation }\end{array}$ & $\begin{array}{l}\text { Sample } \\
\text { Tontion }\end{array}$ & resuili & Yuplicate & Vis.11 \\
\hline \multicolumn{2}{|c|}{ Solvas acre arges } & 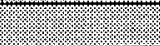 & 1898 & $1 \mathrm{~g} / \mathrm{g}$ & I. $10 \mathrm{~g} 8 \mathrm{~g}$ \\
\hline S98T000695 & $223: 6$ & Whole & 11,800 & 11,900 & 11,900 \\
\hline S98T000705 & $223: 6 \mathrm{~A}$ & Whole & 14,000 & 10,600 & $12,300^{\mathrm{QC}: \mathrm{c}, \mathrm{e}, \mathrm{h}}$ \\
\hline S98T000706 & $223: 9$ & Whole & 10,600 & 10,400 & 10,500 \\
\hline S98T000721 & $224: 2$ & Whole & 8,120 & 8,260 & $8,190^{\mathrm{eC}: \mathrm{d}}$ \\
\hline S98T000722 & $224: 4$ & Whole & 8,620 & 8,580 & 8,600 \\
\hline S98T000723 & $224: 7$ & Whole & 9,020 & 9,410 & 9,220 \\
\hline S98T000724 & $224: 10$ & Whole & 11,100 & 10,900 & 11,000 \\
\hline \multicolumn{2}{|c|}{ Solitis: fusion : } & & 1098 & (1) & 1. \\
\hline S97T002177 & $223: 1$ & Lower half & 8,390 & 4,750 & $6,570^{\mathrm{QC:e}}$ \\
\hline S97T002185 & $223: 2$ & Lower half & 13,700 & 14,200 & 14,000 \\
\hline S97T002194 & $223: 3$ & Lower half & 5,950 & 6,300 & 6,130 \\
\hline S97T002204 & $223: 4$ & Lower half & 7,720 & 5,280 & $6,500^{\mathrm{QC}: \mathrm{e}}$ \\
\hline S97T002231 & $223: 5$ & Lower half & 17,700 & 18,500 & 18,100 \\
\hline S98T000694 & $223: 6$ & Whole & 11,900 & 11,900 & 11,900 \\
\hline S98T000703 & $223: 6 \mathrm{~A}$ & Whole & 13,900 & 14,200 & 14,100 \\
\hline S97T002233 & \multirow[t]{2}{*}{$223: 7$} & Upper half & 30,800 & 30,900 & 30,900 \\
\hline S97T002232 & & Lower half & 25,400 & 26,000 & 25,700 \\
\hline S97T002235 & \multirow[t]{2}{*}{$223: 8$} & Upper half & 30,200 & 29,200 & 29,700 \\
\hline S97T002234 & & Lower half & 19,400 & 20,700 & 20,100 \\
\hline S98T000704 & $223: 9$ & Whole & 10,200 & 12,300 & 11,300 \\
\hline S97T002265 & \multirow[t]{2}{*}{$223: 10$} & Upper half & 21,000 & 22,500 & 21,800 \\
\hline S97T002263 & & Lower half & 24,700 & 24,400 & 24,600 \\
\hline S97T002320 & $224: 1$ & Lower half & 14,100 & 14,400 & 14,300 \\
\hline S98T000717 & $224: 2$ & Whole & 8,970 & 8,780 & 8,880 \\
\hline S97T002334 & $224: 3$ & Lower half & 14,000 & 13,000 & 13,500 \\
\hline S98T000718 & $224: 4$ & Whole & 9,500 & 9,430 & 9,470 \\
\hline
\end{tabular}


Table B2-9. Tank 241-SX-106 Analytical Results: Aluminum (ICP). (2 sheets)

\begin{tabular}{|c|c|c|c|c|c|}
\hline sample & Sample. & 6andol & Resulit & Boyidicate & 1mora \\
\hline \multicolumn{3}{|c|}{ 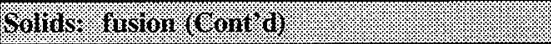 } & (2. & 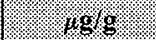 & 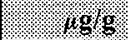 \\
\hline S97T002360 & \multirow[t]{2}{*}{$224: 5$} & Upper half & 12,100 & 15,000 & $13,600^{\text {QC:e }}$ \\
\hline S97T002359 & & Lower half & 25,000 & 24,500 & 24,800 \\
\hline S97T002362 & \multirow[t]{2}{*}{$224: 6$} & Upper half & 30,100 & 29,700 & 29,900 \\
\hline S97T002361 & & Lower half & 31,400 & 31,000 & 31,200 \\
\hline S98T000719 & $224: 7$ & Whole & 9,740 & 9,870 & 9,810 \\
\hline S97T002364 & \multirow[t]{2}{*}{$224: 8$} & Upper half & 22,600 & 24,300 & 23,500 \\
\hline S97T002363 & & Lower half & 29,300 & 26,400 & 27,900 \\
\hline S97T002392 & \multirow[t]{2}{*}{$224: 9$} & Upper half & 18,900 & 18,400 & 18,700 \\
\hline S97T002387 & & Lower half & 24,100 & 23,600 & 23,900 \\
\hline S98T000720 & $224: 10$ & Whole & 12,900 & 11,600 & 12,300 \\
\hline S97T002402 & \multirow[t]{2}{*}{$224: 11$} & Upper half & 36,800 & 36,800 & 36,800 \\
\hline S97T002397 & & Lower half & 24,500 & 23,400 & 24,000 \\
\hline \multicolumn{3}{|l|}{ Grurirs } & $.4 \mathrm{gmo}$ & $105 \%$ & agmin \\
\hline S97T002179 & 223:1 & Drainable liquid & 25,600 & 24,600 & 25,100 \\
\hline S97T002188 & $223: 2$ & Drainable liquid & 25,400 & 23,700 & 24,600 \\
\hline S97T002199 & $223: 3$ & Drainable liquid & 26,400 & 26,500 & $26,500^{\mathrm{QC}: c}$ \\
\hline \$97T002200 & $223: 4$ & Drainable liquid & 25,800 & 24,800 & $25,300^{\mathrm{QC}: \mathrm{c}}$ \\
\hline S97T002215 & $223: 5$ & Drainable liquid & 29,400 & 28,600 & 29,000 \\
\hline S97T002323 & $224: 1$ & Drainable liquid & 26,300 & 26,800 & $26,600^{\mathrm{QC}: c}$ \\
\hline S97T002371 & $224: 3$ & Drainable liquid & 24,900 & 25,200 & 25,100 \\
\hline S97T002372 & $224: 5$ & Drainable liquid & 24,900 & 25,300 & $25,100^{\mathrm{QC}: \mathrm{d}}$ \\
\hline
\end{tabular}


HNF-SD-WM-ER-645 Rev. 1

Table B2-10. Tank 241-SX-106 Analytical Results: Antimony (ICP). (2 sheets)

\begin{tabular}{|c|c|c|c|c|c|}
\hline Shmple & Sormple. & 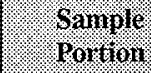 & Resulu & Buplinase & Mero \\
\hline \multicolumn{3}{|c|}{ Wolms, aco } & 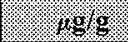 & \% 190 & . \\
\hline S98T000695 & $223: 6$ & Whole & $<24.1$ & $<22.6$ & $<23.4$ \\
\hline S98T000705 & $223: 6 \mathrm{~A}$ & Whole & $<22.5$ & $<23.6$ & $<23.1$ \\
\hline S98T000706 & $223: 9$ & Whole & $<22.8$ & $<22.6$ & $<22.7$ \\
\hline S98T000721 & $224: 2$ & Whole & $<14.5$ & $<10.5$ & $<12.5$ \\
\hline \$98T000722 & $224: 4$ & Whole & $<11.7$ & $<11.5$ & $<11.6$ \\
\hline S98T000723 & $224: 7$ & Whole & $<23.6$ & $<23.3$ & $<23.5$ \\
\hline S98T000724 & $224: 10$ & Whole & $<21.6$ & $<21.2$ & $<21.4$ \\
\hline \multicolumn{3}{|c|}{ 60160s. Gision } & $6 \mathrm{gg}$ & . $.49 \mathrm{~g} g$ & 49 \\
\hline S97T002177 & $223: 1$ & Lower half & $<1,250$ & $<1,220$ & $<1,240$ \\
\hline S97T002185 & $223: 2$ & Lower half & $<1,150$ & $<1,130$ & $<1,140$ \\
\hline S97T002194 & $223: 3$ & Lower half & $<1,130$ & $<1,120$ & $<1,130$ \\
\hline S97T002204 & $223: 4$ & Lower half & $<1,320$ & $<1,290$ & $<1,310$ \\
\hline S97T002231 & $223: 5$ & Lower half & $<1,110$ & $<1,140$ & $<1,130$ \\
\hline S98T000694 & $223: 6$ & Whole & $<1,160$ & $<1,140$ & $<1,150$ \\
\hline S98T000703 & $223: 6 \mathrm{~A}$ & Whole & $<1,110$ & $<1,130$ & $<1,120$ \\
\hline \$97T002233 & \multirow[t]{2}{*}{$223: 7$} & Upper half & $<1,260$ & $<1,200$ & $<1,230$ \\
\hline S97T002232 & & Lower half & $<1,180$ & $<1,220$ & $<1,200$ \\
\hline S97T002235 & \multirow[t]{2}{*}{$223: 8$} & Upper half & $<1,220$ & $<1,210$ & $<1,220$ \\
\hline S97T002234 & & Lower half & $<1,190$ & $<1,200$ & $<1,200$ \\
\hline S98T000704 & $223: 9$ & Whole & $<1,210$ & $<1,220$ & $<1,220$ \\
\hline S97T002265 & \multirow[t]{2}{*}{$223: 10$} & Upper half & $<1,180$ & $<1,180$ & $<1,180$ \\
\hline S97T002263 & & Lower half & $<1,230$ & $<1,230$ & $<1,230$ \\
\hline S97T002320 & $224: 1$ & Lower half & $<1,140$ & $<1,110$ & $<1,130$ \\
\hline \$98T000717 & $224: 2$ & Whole & $<1,210$ & $<1,170$ & $<1,190$ \\
\hline S97T002334 & $224: 3$ & Lower half & $<1,100$ & $<1,110$ & $<1,110$ \\
\hline S98T000718 & $224: 4$ & Whole & $<1,210$ & $<1,190$ & $<1,200$ \\
\hline S97T002360 & \multirow[t]{2}{*}{$224: 5$} & Upper half & $<1,200$ & $<1,220$ & $<1,210$ \\
\hline S97T002359 & & Lower half & $<1,210$ & $<1,200$ & $<1,210$ \\
\hline S97T002362 & \multirow[t]{2}{*}{$224: 6$} & Upper half & $<1,090$ & $<1,050$ & $<1,070$ \\
\hline S97T002361 & & Lower half & $<1,160$ & $<1,170$ & $<1,170$ \\
\hline
\end{tabular}


Table B2-10. Tank 241-SX-106 Analytical Results: Antimony (ICP). (2 sheets)

\begin{tabular}{|c|c|c|c|c|c|}
\hline Sanjule & sample & Samplo & Resulf & Bublicare & Nesin \\
\hline \multicolumn{3}{|c|}{ Soluds: firsion (cont d) } & thog & $109 \mathrm{~g}$ & \%o \\
\hline S98T000719 & $224: 7$ & Whole & $<1,160$ & $<1,200$ & $<1,180$ \\
\hline \$97T002364 & \multirow[t]{2}{*}{$224: 8$} & Upper half & $<1,210$ & $<1,200$ & $<1,210$ \\
\hline S97T002363 & & Lower half & $<1,110$ & $<1,090$ & $<1,100$ \\
\hline S97T002392 & \multirow[t]{2}{*}{$224: 9$} & Upper half & $<1,310$ & $<1,310$ & $<1,310$ \\
\hline S97T002387 & & Lower half & $<1,340$ & $<1,340$ & $<1,340$ \\
\hline S98T000720 & $224: 10$ & Whole & $<1,180$ & $<1,170$ & $<1,180$ \\
\hline S97T002402 & \multirow[t]{2}{*}{$224: 11$} & Upper half & $<1,210$ & $<1,200$ & $<1,210$ \\
\hline \$97T002397 & & Lower half & $<1,180$ & $<1,150$ & $<1,170$ \\
\hline \multicolumn{3}{|l|}{ Siguias } & rg. nu & 148111 & 109111 \\
\hline S97T002179 & $223: 1$ & Drainable liquid & $<36.1$ & $<36.1$ & $<36.1$ \\
\hline S97T002188 & $223: 2$ & Drainable liquid & $<36.1$ & $<36.1$ & $<36.1$ \\
\hline \$97T002199 & $223: 3$ & Drainable liquid & $<36.1$ & $<36.1$ & $<36.1$ \\
\hline S97T002200 & $223: 4$ & Drainable liquid & $<36.1$ & $<36.1$ & $<36.1$ \\
\hline S97T002215 & $223: 5$ & Drainable liquid & $<36.1$ & $<36.1$ & $<36.1$ \\
\hline S97T002323 & $224: 1$ & Drainable liquid & $<36.1$ & $<36.1$ & $<36.1$ \\
\hline S97T002371 & $224: 3$ & Drainable liquid & $<36.1$ & $<36.1$ & $<36.1$ \\
\hline S97T002372 & $224: 5$ & Drainable liquid & $<36.1$ & $<36.1$ & $<36.1$ \\
\hline
\end{tabular}


Table B2-11. Tank 241-SX-106 Analytical Results: Arsenic (ICP). (2 sheets)

\begin{tabular}{|c|c|c|c|c|c|}
\hline Sample & $\begin{array}{l}\text { Samilo } \\
\text { location }\end{array}$ & $\begin{array}{l}\text { Sample } \\
\text { Iortion }\end{array}$ & Resall & Buplingre & Mresi \\
\hline \multicolumn{3}{|c|}{ Solids: acri digest } & 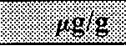 & 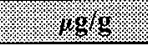 & 1.989 \\
\hline S98T000695 & 223:6 & Whole & $<40.1$ & $<37.6$ & $<38.9$ \\
\hline S98T000705 & $223: 6 \mathrm{~A}$ & Whole & $<37.5$ & $<39.3$ & $<38.4$ \\
\hline S98T000706 & $223: 9$ & Whole & $<38$ & $<37.6$ & $<37.8$ \\
\hline S98T000721 & $224: 2$ & Whole & $<24.2$ & $<17.5$ & $<20.9$ \\
\hline S98T000722 & $224: 4$ & Whole & $<19.4$ & $<19.2$ & $<19.3$ \\
\hline S98T000723 & $224: 7$ & Whole & $<39.3$ & $<38.8$ & $<39$ \\
\hline S98T000724 & $224: 10$ & Whole & $<36$ & $<35.3$ & $<35.6$ \\
\hline \multicolumn{2}{|c|}{ Solids: rusion: } & & 1.989 & $1.98 \mathrm{~g}$ & 4.1898 \\
\hline S97T002177 & $223: 1$ & Lower half & $<2,080$ & $<2,040$ & $<2,060$ \\
\hline S97T002185 & $223: 2$ & Lower half & $<1,920$ & $<1,890$ & $<1,910$ \\
\hline S97T002194 & $223: 3$ & Lower half & $<1,880$ & $<1,870$ & $<1,880$ \\
\hline S97T002204 & $223: 4$ & Lower half & $<2,200$ & $<2,150$ & $<2,180$ \\
\hline \$97T002231 & $223: 5$ & Lower half & $<1,840$ & $<1,900$ & $<1,870$ \\
\hline S98T000694 & $223: 6$ & Whole & $<1,930$ & $<1,890$ & $<1,910$ \\
\hline S98T000703 & $223: 6 \mathrm{~A}$ & Whole & $<1,850$ & $<1,890$ & $<1,870$ \\
\hline S97T002233 & \multirow[t]{2}{*}{$223: 7$} & Upper half & $<2,100$ & $<2,000$ & $<2,050$ \\
\hline S97T002232 & & Lower half & $<1,960$ & $<2,030$ & $<2,000$ \\
\hline S97T002235 & \multirow[t]{2}{*}{$223: 8$} & Upper half & $<2,030$ & $<2,020$ & $<2,030$ \\
\hline S97T002234 & & Lower half & $<1,980$ & $<2,010$ & $<2,000$ \\
\hline S98T000704 & $223: 9$ & Whole & $<2,020$ & $<2,040$ & $<2,030$ \\
\hline S97T002265 & \multirow[t]{2}{*}{$223: 10$} & Upper half & $<1,970$ & $<1,970$ & $<1,970$. \\
\hline S97T002263 & & Lower half & $<2,050$ & $<2,050$ & $<2,050$ \\
\hline S97T002320 & $224: 1$ & Lower half & $<1,900$ & $<1,850$ & $<1,880$ \\
\hline S98T000717 & $224: 2$ & Whole & $<2,020$ & $<1,950$ & $<1 ; 990$ \\
\hline S97T002334 & $224: 3$ & Lower half & $<1,830$ & $<1,850$ & $<1,840$ \\
\hline S98T000718 & $224: 4$ & Whole & $<2,010$ & $<1,990$ & $<2,000$ \\
\hline S97T002360 & \multirow[t]{2}{*}{$224: 5$} & Upper half & $<2,000$ & $<2,040$ & $<2,020$ \\
\hline S97T002359 & & Lower half & $<2,020$ & $<2,000$ & $<2,010$ \\
\hline S97T002362 & \multirow[t]{2}{*}{$224: 6$} & Upper half & $<1,820$ & $<1,750$ & $<1,790$ \\
\hline S97T002361 & & Lower half & $<1,930$ & $<1,960$ & $<1,950$ \\
\hline
\end{tabular}


Table B2-11. Tank 241-SX-106 Analytical Results: Arsenic (ICP). (2 sheets)

\begin{tabular}{|c|c|c|c|c|c|}
\hline whinuer & Sorvilo & 69mole & resulut & Duplicate & Merin. \\
\hline \multicolumn{3}{|c|}{ 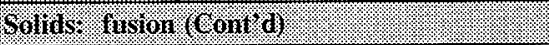 } & 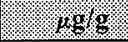 & 1.1 .969 & 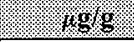 \\
\hline S98T000719 & $224: 7$ & Whole & $<1,930$ & $<2,000$ & $<1,970$ \\
\hline \$97T002364 & \multirow[t]{2}{*}{$224: 8$} & Upper half & $<2,020$ & $<2,010$ & $<2,020$ \\
\hline \$97T002363 & & Lower half & $<1,850$ & $<1,810$ & $<1,830$ \\
\hline S97T002392 & \multirow[t]{2}{*}{$224: 9$} & Upper half & $<2,190$ & $<2,190$ & $<2,190$ \\
\hline S97T002387 & & Lower half & $<2,230$ & $<2,240$ & $<2,240$ \\
\hline S98T000720 & $224: 10$ & Whole & $<1,960$ & $<1,950$ & $<1,960$ \\
\hline S97T002402 & \multirow[t]{2}{*}{$224: 11$} & Upper half & $<2,010$ & $<2,010$ & $<2,010$ \\
\hline S97T002397 & & Lower half & $<1,970$ & $<1,920$ & $<1,950$ \\
\hline Hinuas & \multicolumn{2}{|l|}{ (1. } & $40 \% 114$ & . & \%glm \\
\hline \$97T002179 & $223: 1$ & Drainable liquid & $<60.1$ & $<60.1$ & $<60.1$ \\
\hline S97T002188 & $223: 2$ & Drainable liquid & $<60.1$ & $<60.1$ & $<60.1$ \\
\hline S97T002199 & $223: 3$ & Drainable liquid & $<60.1$ & $<60.1$ & $<60.1$ \\
\hline S97T002200 & $223: 4$ & Drainable liquid & $<60.1$ & $<60.1$ & $<60.1$ \\
\hline S97T002215 & $223: 5$ & Drainable liquid & $<60.1$ & $<60.1$ & $<60.1$ \\
\hline \$97T002323 & $224: 1$ & Drainable liquid & $<60.1$ & $<60.1$ & $<60.1$ \\
\hline S97T002371 & $224: 3$ & Drainable liquid & $<60.1$ & $<60.1$ & $<60.1$ \\
\hline S97T002372 & $224: 5$ & Drainable liquid & $<60.1$ & $<60.1$ & $<60.1$ \\
\hline
\end{tabular}


Table B2-12. Tank 241-SX-106 Analytical Results: Barium (ICP). (2 sheets)

\begin{tabular}{|c|c|c|c|c|c|}
\hline Sampile & $\begin{array}{l}\text { Sample. } \\
\text { leocation }\end{array}$ & $\begin{array}{l}\text { Sample } \\
\text { eortion }\end{array}$ & Result & Bupliare & Meran \\
\hline \multicolumn{2}{|c|}{ Solids: acid digest } & 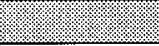 & 1,298 & 1838 & 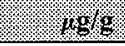 \\
\hline S98T000695 & $223: 6$ & Whole & $<20.1$ & $<18.8$ & $<19.5$ \\
\hline S98T000705 & $223: 6 \mathrm{~A}$ & Whole & $<18.7$ & $<19.6$ & $<19.1$ \\
\hline S98T000706 & 223:9 & Whole & $<19$ & $<18.8$ & $<18.9$ \\
\hline S98T000721 & $224: 2$ & Whole & $<12.1$ & $<8.76$ & $<10.4$ \\
\hline S98T000722 & $224: 4$ & Whole & $<9.72$ & $<9.58$ & $<9.65$ \\
\hline S98T000723 & $224: 7$ & Whole & $<19.7$ & $<19.4$ & $<19.5$ \\
\hline S98T000724 & $224: 10$ & Whole & $<18$ & $<17.7$ & $<17.9$ \\
\hline \multicolumn{2}{|c|}{ Solids fusion : } & & 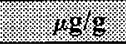 & $.1 .98 \mathrm{~g}$ & . 1919 \\
\hline S97T002177 & $223: 1$ & Lower half & $<1,040$ & $<1,020$ & $<1,030$ \\
\hline S97T002185 & $223: 2$ & Lower half & $<958$ & $<946$ & $<952$ \\
\hline S97T002194 & $223: 3$ & Lower half & $<939$ & $<934$ & $<937$ \\
\hline S97T002204 & $223: 4$ & Lower half & $<1,100$ & $<1,070$ & $<1,090$ \\
\hline S97T002231 & $223: 5$ & Lower half & $<922$ & $<951$ & $<937$ \\
\hline S98T000694 & $223: 6$ & Whole & $<965$ & $<946$ & $<956$ \\
\hline S98T000703 & $223: 6 \mathrm{~A}$ & Whole & $<926$ & $<943$ & $<935$ \\
\hline S97T002233 & \multirow[t]{2}{*}{$223: 7$} & Upper half & $<1,050$ & $<1,000$ & $<1,030$ \\
\hline S97T002232 & & Lower half & $<979$ & $<1,010$ & $<995$ \\
\hline S97T002235 & \multirow[t]{2}{*}{$223: 8$} & Upper half & $<1,010$ & $<1,010$ & $<1,010$ \\
\hline S97T002234 & & Lower half & $<992$ & $<1,000$ & $<996$ \\
\hline S98T000704 & $223: 9$ & Whole & $<1,010$ & $<1,020$ & $<1,020$ \\
\hline S97T002265 & \multirow[t]{2}{*}{$223: 10$} & Upper half & $<985$ & $<984$ & $<985$ \\
\hline S97T002263 & & Lower half & $<1,020$ & $<1,030$ & $<1,030$ \\
\hline S97T002320 & $224: 1$ & Lower half & $<950$ & $<923$ & $<937$ \\
\hline S98T000717 & $224: 2$ & Whole & $<1,010$ & $<976$ & $<993$ \\
\hline S97T002334 & $224: 3$ & Lower half & $<914$ & $<923$ & $<919$ \\
\hline S98T000718 & $224: 4$ & Whole & $<1,010$ & $<995$ & $<1,000$ \\
\hline S97T002360 & \multirow[t]{2}{*}{$224: 5$} & Upper half & $<999$ & $<1,020$ & $<1,010$ \\
\hline S97T002359 & & Lower half & $<1,010$ & $<999$ & $<1,000$ \\
\hline S97T002362 & \multirow[t]{2}{*}{$224: 6$} & Upper half & $<910$ & $<873$ & $<892$ \\
\hline S97T002361 & & Lower half & $<967$ & $<978$ & $<973$ \\
\hline
\end{tabular}


Table B2-12. Tank 241-SX-106 Analytical Results: Barium (ICP). (2 sheets)

\begin{tabular}{|c|c|c|c|c|c|}
\hline $\begin{array}{l}\text { Samples } \\
\text { Simuber }\end{array}$ & Somple & $\begin{array}{l}\text { Sampre } \\
\text { Portion }\end{array}$ & Resulil & Minlicate & Mear \\
\hline \multicolumn{3}{|c|}{ Solins: frision (Cont d) } & 1456 & $10 \mathrm{gg}$ & .1098 \\
\hline S98T000719 & $224: 7$ & Whole & $<967$ & $<999$ & $<983$ \\
\hline S97T002364 & \multirow[t]{2}{*}{$224: 8$} & Upper half & $<1,010$ & $<1,000$ & $<1,010$ \\
\hline S97T002363 & & Lower half & $<923$ & $<905$ & $<914$ \\
\hline S97T002392 & \multirow[t]{2}{*}{$224: 9$} & Upper half & $<1,090$ & $<1,100$ & $<1,100$ \\
\hline S97T002387 & & Lower half & $<1,120$ & $<1,120$ & $<1,120$ \\
\hline S98T000720 & $224: 10$ & Whole & $<982$ & $<976$ & $<979$ \\
\hline S97T002402 & \multirow{2}{*}{$224: 11$} & Upper half & $<1,010$ & $<1,000$ & $<1,010$ \\
\hline S97T002397 & & Lower half & $<984$ & $<962$ & $<973$ \\
\hline \multicolumn{3}{|c|}{ Mrivols } & r.84ing & $3.9 .98 \mathrm{~min}$ & $.9 \mathrm{gmin}$ \\
\hline S97T002179 & $223: 1$ & Drainable liquid & $<30.1$ & $<30.1$ & $<30.1$ \\
\hline S97T002188 & $223: 2$ & Drainable liquid & $<30.1$ & $<30.1$ & $<30.1$ \\
\hline S97T002199 & $223: 3$ & Drainable liquid. & $<30.1$ & $<30.1$ & $<30.1$ \\
\hline S97T002200 & $223: 4$ & Drainable liquid & $<30.1$ & $<30.1$ & $<30.1$ \\
\hline S97T002215 & $223: 5$ & Drainable liquid & $<30.1$ & $<30.1$ & $<30.1$ \\
\hline S97T002323 & $224: 1$ & Drainable liquid & $<30.1$ & $<30.1$ & $<30.1$ \\
\hline S97T002371 & $224: 3$ & Drainable liquid & $<30.1$ & $<30.1$ & $<30.1$ \\
\hline S97T002372 & $224: 5$ & Drainable liquid & $<30.1$ & $<30.1$ & $<30.1$ \\
\hline
\end{tabular}


Table B2-13. Tank 241-SX-106 Analytical Results: Beryllium (ICP). (2 sheets)

\begin{tabular}{|c|c|c|c|c|c|}
\hline Sample & .64010 & gampor & Resull & 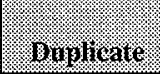 & Mean \\
\hline \multicolumn{2}{|c|}{ 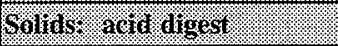 } & & 1.1 .519 .7$. & : & roges \\
\hline S98T000695 & $223: 6$ & Whole & $<2.01$ & $<1.88$ & $<1.94$ \\
\hline S98T000705 & $223: 6 \mathrm{~A}$ & Whole & $<1.87$ & $<1.96$ & $<1.92$ \\
\hline S98T000706 & $223: 9$ & Whole & $<1.9$ & $<1.88$ & $<1.89$ \\
\hline S98T000721 & $224: 2$ & Whole & $<1.21$ & $<0.876$ & $<1.04$ \\
\hline S98T000722 & $224: 4$ & Whole & $<0.972$ & $<0.958$ & $<0.965$ \\
\hline S98T000723 & $224: 7$ & Whole & $<1.97$ & $<1.94$ & $<1.96$ \\
\hline S98T000724 & $224: 10$ & Whole & $<1.8$ & $<1.77$ & $<1.79$ \\
\hline \multicolumn{2}{|c|}{ Solins: fusion: } & & 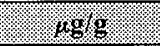 & . & 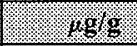 \\
\hline S97T002177 & $223: 1$ & Lower half & $<104$ & $<102$ & $<103$ \\
\hline S97T002185 & $223: 2$ & Lower half & $<95.8$ & $<94.6$ & $<95.2$ \\
\hline S97T002194 & $223: 3$ & Lower half & $<93.9$ & $<93.4$ & $<93.7$ \\
\hline \$97T002204 & $223: 4$ & Lower half & $<110$ & $<107$ & $<109$ \\
\hline \$97T002231 & $223: 5$ & Lower half & $<92.2$ & $<95.1$ & $<93.7$ \\
\hline S98T000694 & $223: 6$ & Whole & $<96.5$ & $<94.6$ & $<95.5$ \\
\hline \$98T000703 & $223: 6 \mathrm{~A}$ & Whole & $<92.6$ & $<94.3$ & $<93.4$ \\
\hline \$97T002233 & \multirow[t]{2}{*}{$223: 7$} & Upper half & $<105$ & $<100$ & $<103$ \\
\hline S97T002232 & & Lower half & $<97.9$ & $<101$ & $<99.5$ \\
\hline \$97T002235 & \multirow[t]{2}{*}{$223: 8$} & Upper half & $<101$ & $<101$ & $<101$ \\
\hline S97T002234 & & Lower half & $<99.2$ & $<100$ & $<99.6$ \\
\hline S98T000704 & $223: 9$ & Whole & $<101$ & $<102$ & $<102$ \\
\hline S97T002265 & \multirow[t]{2}{*}{$223: 10$} & Upper half & $<98.5$ & $<98.4$ & $<98.5$ \\
\hline \$97T002263 & & Lower half & $<102$ & $<103$ & $<103$ \\
\hline \$97T002320 & $224: 1$ & Lower half & $<95$ & $<92.3$ & $<93.7$ \\
\hline \$98T000717 & $224: 2$ & Whole & $<101$ & $<97.6$ & $<99.3$ \\
\hline S97T002334 & $224: 3$ & Lower half & $<91.4$ & $<92.3$ & $<91.8$ \\
\hline \$98T000718 & $224: 4$ & Whole & $<101$ & $<99.5$ & $<100$ \\
\hline S97'T002360 & \multirow[t]{2}{*}{$224: 5$} & Upper half & $<99.9$ & $<102$ & $<101$ \\
\hline S97T002359 & & Lower half & $<101$ & $<99.9$ & $<100$ \\
\hline S97T002362 & \multirow[t]{2}{*}{$224: 6$} & Upper half & $<91$ & $<87.3$ & $<89.2$ \\
\hline \$97T002361 & & Lower half & $<96.7$ & $<97.8$ & $<97.3$ \\
\hline
\end{tabular}


Table B2-13. Tank 241-SX-106 Analytical Results: Beryllium (ICP). (2 sheets)

\begin{tabular}{|c|c|c|c|c|c|}
\hline Samile & Soralon & Saunue & Resulg & Byigivare & 1era \\
\hline \multicolumn{3}{|c|}{ 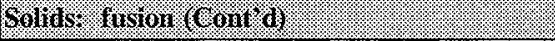 } & 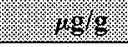 & . & . \\
\hline S98T000719 & $224: 7$ & Whole & $<96.7$ & $<99.9$ & $<98.3$ \\
\hline \$97T002364 & \multirow[t]{2}{*}{$224: 8$} & Upper half & $<101$ & $<100$ & $<101$ \\
\hline S97T002363 & & Lower half & $<92.3$ & $<90.5$ & $<91.4$ \\
\hline \$97T002392 & \multirow[t]{2}{*}{$224: 9$} & Upper half & $<109$ & $<110$ & $<110$ \\
\hline \$97T002387 & & Lower half & $<112$ & $<112$ & $<112$ \\
\hline S98T000720 & $224: 10$ & Whole & $<98.2$ & $<97.6$ & $<97.9$ \\
\hline S97T002402 & \multirow[t]{2}{*}{$224: 11$} & Upper half & $<101$ & $<100$ & $<101$ \\
\hline S97T002397 & & Lower half & $<98.4$ & $<96.2$ & $<97.3$ \\
\hline \multicolumn{2}{|l|}{ Wungss } & & 10114 & 18, 110 & $10 \% 111$ \\
\hline \$97T002179 & $223: 1$ & Drainable liquid & $<3$ & $<3$ & $<3$ \\
\hline S97T002188 & $223: 2$ & Drainable liquid & $<3$ & $<3$ & $<3$ \\
\hline \$97T002199 & $223: 3$ & Drainable liquid & $<3$ & $<3$ & $<3$ \\
\hline S97T002200 & $223: 4$ & Drainable liquid & $<3$ & $<3$ & $<3$ \\
\hline S97T002215 & $223: 5$ & Drainable liquid & $<3$ & $<3$ & $<3$ \\
\hline S97T002323 & $224: 1$ & Drainable liquid & $<3$ & $<3$ & $<3$ \\
\hline S97T002371 & $224: 3$ & Drainable liquid & $<3$ & $<3$ & $<3$ \\
\hline S97T002372 & $224: 5$ & Drainable liquid & $<3$ & $<3$ & $<3$ \\
\hline
\end{tabular}


Table B2-14. Tank 241-SX-106 Analytical Results: Bismuth (ICP). (2 sheets)

\begin{tabular}{|c|c|c|c|c|c|}
\hline Sample & Sample & parrole & Hesili: & Moulinate & Mean \\
\hline \multicolumn{2}{|c|}{ 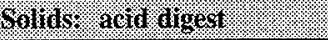 } & 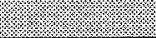 & 140 & 1698 & 1696 \\
\hline S98T000695 & $223: 6$ & Whole & $<40.1$ & $<37.6$ & $<38.9$ \\
\hline S98T000705 & $223: 6 \mathrm{~A}$ & Whole & $<37.5$ & $<39.3$ & $<38.4$ \\
\hline S98T000706 & $223: 9$ & Whole & $<38$ & $<37.6$ & $<37.8$ \\
\hline S98T000721 & $224: 2$ & Whole & $<24.2$ & $<17.5$ & $<20.9$ \\
\hline S98T000722 & $224: 4$ & Whole & $<19.4$ & $<19.2$ & $<19.3$ \\
\hline S98T000723 & $224: 7$ & Whole & $<39.3$ & $<38.8$ & $<39$ \\
\hline S98T000724 & $224: 10$ & Whole & $<36$ & $<35.3$ & $<35.6$ \\
\hline \multicolumn{2}{|l|}{ folldis\% Uision } & & (1. & $16 \mathrm{~g}$ & 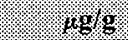 \\
\hline \$97T002177 & $223: 1$ & Lower half & $<2,080$ & $<2,040$ & $<2,060$ \\
\hline S97T002185 & $223: 2$ & Lower half & $<1,920$ & $<1,890$ & $<1,910$ \\
\hline \$97T002194 & $223: 3$ & Lower half & $<1,880$ & $<1,870$ & $<1,880$ \\
\hline \$97T002204 & $223: 4$ & Lower half & $<2,200$ & $<2,150$ & $<2,180$ \\
\hline \$97T002231 & $223: 5$ & Lower half & $<1,840$ & $<1,900$ & $<18,70$ \\
\hline S98T000694 & $223: 6$ & Whole & $<1,930$ & $<1,890$ & $<1,910$ \\
\hline S98T000703 & 223:6A & Whole & $<1,850$ & $<1,890$ & $<1,870$ \\
\hline S97T002233 & \multirow[t]{2}{*}{$223: 7$} & Upper half & $<2,100$ & $<2,000$ & $<2,050$ \\
\hline S97T002232 & & Lower half & $<1,960$ & $<2,030$ & $<2,000$ \\
\hline S97T002235 & \multirow[t]{2}{*}{$223: 8$} & Upper half & $<2,030$ & $<2,020$ & $<2,030$ \\
\hline S97T002234 & & Lower half & $<1,980$ & $<2,010$ & $<2,000$ \\
\hline S98T000704 & $223: 9$ & Whole & $<2,020$ & $<2,040$ & $<2,030$ \\
\hline S97T002265 & \multirow[t]{2}{*}{$223: 10$} & Upper half & $<1,970$ & $<1,970$ & $<1,970$ \\
\hline S97T002263 & & Lower half & $<2,050$ & $<2,050$ & $<2,050$ \\
\hline S97T002320 & $224: 1$ & Lower half & $<1,900$ & $<1,850$ & $<1,880$ \\
\hline \$98T000717 & $224: 2$ & Whole & $<2,020$ & $<1,950$ & $<1,990$ \\
\hline S97T002334 & $224: 3$ & Lower half & $<1,830$ & $<1,850$ & $<1,840$ \\
\hline S98T000718 & $224: 4$ & Whole & $<2,010$ & $<1,990$ & $<2,000$ \\
\hline \$97T002360 & \multirow[t]{2}{*}{$224: 5$} & Upper half & $<2,000$ & $<2,040$ & $<2,020$ \\
\hline S97T002359 & & Lower half & $<2,020$ & $<2,000$ & $<2,010$ \\
\hline S97T002362 & \multirow[t]{2}{*}{$224: 6$} & Upper half & $<1,820$ & $<1,750$ & $<1,790$ \\
\hline S97T002361 & & Lower half & $<1,930$ & $<1,960$ & $<1,950$ \\
\hline
\end{tabular}


Table B2-14. Tank 241-SX-106 Analytical Results: Bismuth (ICP). (2 sheets)

\begin{tabular}{|c|c|c|c|c|c|}
\hline $\begin{array}{l}\text { Sample } \\
\text { Number }\end{array}$ & Sample & $\begin{array}{l}\text { Sample } \\
\text { Portion }\end{array}$ & Ressill & Buplicate & vean \\
\hline \multicolumn{2}{|c|}{ 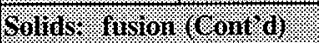 } & (3) & 1,890 & $1.0 .8 \mathrm{~g}$ & 1.989 \\
\hline S98T000719 & $224: 7$ & Whole & $<1,930$ & $<2,000$ & $<1,970$ \\
\hline S97T002364 & \multirow[t]{2}{*}{$224: 8$} & Upper half & $<2,020$ & $<2,010$ & $<2,020$ \\
\hline S97T002363 & & Lower half & $<1,850$ & $<1,810$ & $<1,830$ \\
\hline S97T002392 & \multirow[t]{2}{*}{$224: 9$} & Upper half & $<2,190$ & $<2,190$ & $<2,190$ \\
\hline S97T002387 & & Lower half & $<2,230$ & $<2,240$ & $<2,240$ \\
\hline S98T000720 & $224: 10$ & Whole & $<1,960$ & $<1,950$ & $<1,960$ \\
\hline S97T002402 & \multirow[t]{2}{*}{$224: 11$} & Upper half & $<2,010$ & $<2,010$ & $<2,010$ \\
\hline S97T002397 & & Lower half & $<1,970$ & $<1,920$ & $<1,950$ \\
\hline \multicolumn{2}{|l|}{ Minuts: } & 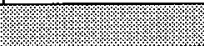 & 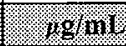 & 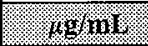 & 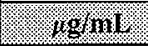 \\
\hline S97T002179 & $223: 1$ & Drainable liquid & $<60.1$ & $<60.1$ & $<60.1$ \\
\hline S97T002188 & $223: 2$ & Drainable liquid & $<60.1$ & $<60.1$ & $<60.1$ \\
\hline S97T002199 & $223: 3$ & \begin{tabular}{|l|} 
Drainable liquid \\
\end{tabular} & $<60.1$ & $<60.1$ & $<60.1$ \\
\hline S97T002200 & $223: 4$ & Drainable liquid & $<60.1$ & $<60.1$ & $<60.1$ \\
\hline S97T002215 & $223: 5$ & Drainable liquid & $<60.1$ & $<60.1$ & $<60.1$ \\
\hline S97T002323 & $224: 1$ & Drainable liquid & $<60.1$ & $<60.1$ & $<60.1$ \\
\hline S97T002371 & $224: 3$ & Drainable liquid & $<60.1$ & $<60.1$ & $<60.1$ \\
\hline S97T002372 & $224: 5$ & Drainable liquid & $<60.1$ & $<60.1$ & $<60.1$ \\
\hline
\end{tabular}


Table B2-15. Tank 241-SX-106 Analytical Results: Boron (ICP). (2 sheets)

\begin{tabular}{|c|c|c|c|c|c|}
\hline $\begin{array}{l}\text { Sample } \\
\text { Number }\end{array}$ & $\begin{array}{l}\text { Sample } \\
\text { Localion }\end{array}$ & $\begin{array}{l}\text { Sample } \\
\text { Sortion } \\
\end{array}$ & Resul & Buplicate & 190.1 \\
\hline \multicolumn{3}{|c|}{ Solins: acid digest : } & 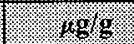 & $409 \mathrm{~g}$ & (3. \\
\hline S98T000695 & $223: 6$ & Whole & 193 & 146 & $170^{\mathrm{OC}: \mathrm{e}}$ \\
\hline S98T000705 & $223: 6 \mathrm{~A}$ & Whole & 127 & 131 & 129 \\
\hline S98T000706 & $223: 9$ & Whole & 161 & 124 & $143^{\mathrm{QC}: c}$ \\
\hline S98T000721 & $224: 2$ & Whole & 134 & 133 & 134 \\
\hline S98T000722 & $224: 4$ & Whole & 130 & 113 & 122 \\
\hline S98T000723 & $224: 7$ & Whole & 149 & 145 & 147 \\
\hline S98T000724 & $224: 10$ & Whole & 141 & 107 & $124^{\mathrm{QC}: \mathrm{e}}$ \\
\hline \multicolumn{2}{|c|}{ Solides: Gissin } & 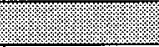 & 1.918 & 1.998 & 1.1989 \\
\hline S97T002177 & $223: 1$ & Lower half & $<1,040$ & $<1,020$ & $<1,030$ \\
\hline S97T002185 & $223: 2$ & Lower half & $<958$ & $<946$ & $<952$ \\
\hline S97T002194 & $223: 3$ & Lower half & $<939$ & $<934$ & $<937$ \\
\hline S97T002204 & $223: 4$ & Lower half & $<1,100$ & $<1,070$ & $<1,090$ \\
\hline S97T002231 & $223: 5$ & Lower half & $<922$ & $<951$ & $<937$ \\
\hline S98T000694 & $223: 6$ & Whole & $<965$ & $<946$ & $<956$ \\
\hline S98T000703 & $223: 6 \mathrm{~A}$ & Whole & $<926$ & $<943$ & $<935$ \\
\hline S97T002233 & \multirow[t]{2}{*}{$223: 7$} & Upper half & $<1,050$ & $<1,000$ & $<1,030$ \\
\hline S97T002232 & & Lower half & $<979$ & $<1,010$ & $<995$ \\
\hline S97T002235 & \multirow[t]{2}{*}{$223: 8$} & Upper half & $<1,010$ & $<1,010$ & $<1,010$ \\
\hline \begin{tabular}{|l|} 
S97T002234 \\
\end{tabular} & & Lower half & $<992$ & $<1,000$ & $<996$ \\
\hline S98T000704 & $223: 9$ & Whole & $<1,010$ & $<1,020$ & $<1,020$ \\
\hline S97T002265 & \multirow[t]{2}{*}{$223: 10$} & Upper half & $<985$ & $<984$ & $<985$ \\
\hline S97T002263 & & Lower half & $<1,020$ & $<1,030$ & $<1,030$ \\
\hline S97T002320 & $224: 1$ & Lower half & $<950$ & $<923$ & $<937$ \\
\hline S98T000717 & $224: 2$ & Whole & $<1,010$ & $<976$ & $<993$ \\
\hline S97T002334 & $224: 3$ & Lower half & $<914$ & $<923$ & $<919$ \\
\hline S98T000718 & $224: 4$ & Whole & $<1,010$ & $<995$ & $<1,000$ \\
\hline S97T002360 & \multirow[t]{2}{*}{$224: 5$} & Upper half & $<999$ & $<1,020$ & $<1,010$ \\
\hline \begin{tabular}{|l|} 
S97T002359 \\
\end{tabular} & & Lower half & $<1,010$ & $<999$ & $<1,000$ \\
\hline S97T002362 & \multirow[t]{2}{*}{$224: 6$} & Upper half & $<910$ & $<873$ & $<892$ \\
\hline S97T002361 & & Lower half & $<967$ & $<978$ & $<973$ \\
\hline
\end{tabular}


HNF-SD-WM-ER-645 Rev. 1

Table B2-15. Tank 241-SX-106 Analytical Results: Boron (ICP). (2 sheets)

\begin{tabular}{|c|c|c|c|c|c|}
\hline bamule & Soraporor & 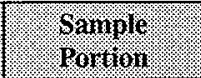 & Resulu & Bupleate & (1) \\
\hline \multicolumn{3}{|c|}{ 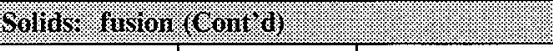 } & 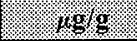 & $.61 \mathrm{~g}$ & 189 \\
\hline \$98T000719 & $224: 7$ & Whole & $<967$ & $<999$ & $<983$ \\
\hline S97T002364 & \multirow[t]{2}{*}{$224: 8$} & Upper half & $<1,010$ & $<1,000$ & $<1,010$ \\
\hline S97T002363 & & Lower half & $<923$ & $<905$ & $<914$ \\
\hline S97T002392 & \multirow[t]{2}{*}{$224: 9$} & Upper half & $<1,090$ & $<1,100$ & $<1,100$ \\
\hline \$97T002387 & & Lower half & $<1,120$ & $<1,120$ & $<1,120$ \\
\hline S98T000720 & $224: 10$ & Whole & $<982$ & $<976$ & $<979$ \\
\hline$\$ 97 T 002402$ & \multirow[t]{2}{*}{$224: 11$} & Upper half & $<1,010$ & $<1,000$ & $<1,010$ \\
\hline \$97T002397 & & Lower half & $<984$ & $<962$ & $<973$ \\
\hline \multicolumn{3}{|l|}{ girind } & 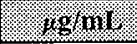 & 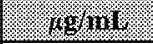 & \% \\
\hline S97T002179 & $223: 1$ & Drainable liquid & 94.7 & 87.1 & 90.9 \\
\hline S97T002188 & $223: 2$ & Drainable liquid & 92.1 & 86.3 & 89.2 \\
\hline S97T002199 & $223: 3$ & Drainable liquid & 94.7 & 94.9 & 94.8 \\
\hline S97T002200 & $223: 4$ & Drainable liquid & 95.9 & 91.9 & 93.9 \\
\hline S97T002215 & $223: 5$ & Drainable liquid & 96.7 & 93.1 & 94.9 \\
\hline S97T002323 & $224: 1$ & Drainable liquid & 99.9 & 100 & 100 \\
\hline S97T002371 & $224: 3$ & Drainable liquid & 95.1 & 96.4 & 95.8 \\
\hline S97T002372 & $224: 5$ & Drainable liquid & 87.1 & 88.4 & 87.8 \\
\hline
\end{tabular}


Table B2-16. Tank 241-SX-106 Analytical Results: Cadmium (ICP). (2 sheets)

\begin{tabular}{|c|c|c|c|c|c|}
\hline $\begin{array}{l}\text { Sample: } \\
\text { Vumber }\end{array}$ & $\begin{array}{l}\text { Sample } \\
\text { Eocation }\end{array}$ & $\begin{array}{l}\text { Sample: } \\
\text { Partion. }\end{array}$ & recull & Bunleate & Ment \\
\hline \multicolumn{3}{|c|}{ Solitis: aciol digest } & $(., 48 \% \mathrm{~s}$ & 1998 & l. \\
\hline S98T000695 & $223: 6$ & Whole & 3.54 & 4 & 3.77 \\
\hline S98T000705 & $223: 6 \mathrm{~A}$ & Whole & 5.3 & 3.76 & $4.53^{\mathrm{QC}: \mathrm{e}}$ \\
\hline S98T000706 & $223: 9$ & Whole & 4.27 & 4.01 & 4.14 \\
\hline S98T000721 & $224: 2$ & Whole & $<1.21$ & $<0.876$ & $<1.04$ \\
\hline S98T000722 & $224: 4$ & Whole & $<0.972$ & $<0.958$ & $<0.965$ \\
\hline S98T000723 & $224: 7$ & Whole & 2.43 & 2.78 & 2.61 \\
\hline S98T000724 & $224: 10$ & Whole & 3.52 & 3.56 & 3.54 \\
\hline \multicolumn{3}{|c|}{ Solitis fusion : } & 11919 & 1.989 & . $19 / 9$ \\
\hline S97T002177 & $223: 1$ & Lower half & $<104$ & $<102$ & $<103$ \\
\hline S97T002185 & $223: 2$ & Lower half & $<95.8$ & $<94.6$ & $<95.2$ \\
\hline S97T002194 & $223: 3$ & Lower half & $<93.9$ & $<93.4$ & $<93.7$ \\
\hline S97T002204 & $223: 4$ & Lower half & $<110$ & $<107$ & $<109$ \\
\hline S97T002231 & $223: 5$ & Lower half & $<92.2$ & $<95.1$ & $<93.7$ \\
\hline S98T000694 & $223: 6$ & Whole & $<96.5$ & $<94.6$ & $<95.5$ \\
\hline S98T000703 & $223: 6 \mathrm{~A}$ & Whole & $<92.6$ & $<94.3$ & $<93.4$ \\
\hline S97T002233 & \multirow[t]{2}{*}{$223: 7$} & Upper half & $<105$ & $<100$ & $<103$ \\
\hline S97T002232 & & Lower half & $<97.9$ & $<101$ & $<99.5$ \\
\hline S97T002235 & \multirow[t]{2}{*}{$223: 8$} & Upper half & $<101$ & $<101$ & $<101$ \\
\hline S97T002234 & & Lower half & $<99.2$ & $<100$ & $<99.6$ \\
\hline S98T000704 & $223: 9$ & Whole & $<101$ & $<102$ & $<102$ \\
\hline S97T002265 & \multirow[t]{2}{*}{$223: 10$} & Upper half & $<98.5$ & $<98.4$ & $<98.5$ \\
\hline S97T002263 & & Lower half & $<102$ & $<103$ & $<103$ \\
\hline S97T002320 & $224: 1$ & Lower half & $<95$ & $<92.3$ & $<93.7$ \\
\hline S98T000717 & $224: 2$ & Whole & $<101$ & $<97.6$ & $<99.3$ \\
\hline S97T002334 & $224: 3$ & Lower half & $<91.4$ & $<92.3$ & $<91.8$ \\
\hline S98T000718 & $224: 4$ & Whole & $<101$ & $<99.5$ & $<100$ \\
\hline S97T002360 & \multirow[t]{2}{*}{$224: 5$} & Upper half & $<99.9$ & $<102$ & $<101$ \\
\hline \begin{tabular}{|l|} 
S97T002359 \\
\end{tabular} & & Lower half & $<101$ & $<99.9$ & $<100$ \\
\hline S97T002362 & \multirow[t]{2}{*}{$224: 6$} & Upper half & $<91$ & $<87.3$ & $<89.2$ \\
\hline \begin{tabular}{|l|} 
S97T002361 \\
\end{tabular} & & Lower half & $<96.7$ & $<97.8$ & $<97.3$ \\
\hline
\end{tabular}


Table B2-16. Tank 241-SX-106 Analytical Results: Cadmium (ICP). (2 sheets)

\begin{tabular}{|c|c|c|c|c|c|}
\hline $\begin{array}{l}\text { Sanuple } \\
\text { Number }\end{array}$ & Samplo. & $\begin{array}{l}\text { Sample } \\
\text { portion }\end{array}$ & Resiul & Dipliciare: & (1) \\
\hline \multicolumn{3}{|c|}{ Solfis frision (coni d) : } & $.098 \mathrm{~g}$ & 1.96 & 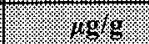 \\
\hline S98T000719 & $224: 7$ & Whole & $<96.7$ & $<99.9$ & $<98.3$ \\
\hline S97T002364 & \multirow[t]{2}{*}{$224: 8$} & Upper half & $<101$ & $<100$ & $<101$ \\
\hline S97T002363 & & Lower half & $<92.3$ & $<90.5$ & $<91.4$ \\
\hline S97T002392 & \multirow[t]{2}{*}{$224: 9$} & Upper half & $<109$ & $<110$ & $<110$ \\
\hline S97T002387 & & Lower half & $<112$ & $<112$ & $<112$ \\
\hline S98T000720 & $224: 10$ & Whole & $<98.2$ & $<97.6$ & $<97.9$ \\
\hline S97T002402 & \multirow[t]{2}{*}{$224: 11$} & Upper half & $<101$ & $<100$ & $<101$ \\
\hline S97T002397 & & Lower half & $<98.4$ & $<96.2$ & $<97.3$ \\
\hline \multicolumn{3}{|l|}{ Whatas: } & 4.969 .10 & 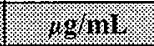 & (3. $18 \mathrm{~g} / \mathrm{nu}$ \\
\hline S97T002179 & $223: 1$ & Drainable liquid & $<3$ & $<3$ & $<3$ \\
\hline S97T002188 & $223: 2$ & Drainable liquid & $<3$ & $<3$ & $<3$ \\
\hline S97T002199 & $223: 3$ & Drainable liquid & $<3$ & $<3$ & $<3$ \\
\hline S97T002200 & $223: 4$ & Drainable liquid & $<3$ & $<3$ & $<3$ \\
\hline S97T002215 & $223: 5$ & Drainable liquid & $<3$ & $<3$ & $<3$ \\
\hline S97T002323 & $224: 1$ & Drainable liquid & $<3$ & $<3$ & $<3$ \\
\hline S97T002371 & $224: 3$ & Drainable liquid & $<3$ & $<3$ & $<3$ \\
\hline S97T002372 & $224: 5$ & Drainable liquid & $<3$ & $<3$ & $<3$ \\
\hline
\end{tabular}


Table B2-17. Tank 241-SX-106 Analytical Results: Calcium (ICP). (2 sheets)

\begin{tabular}{|c|c|c|c|c|c|}
\hline Sample & 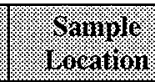 & sompo & kesy & guplod & 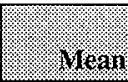 \\
\hline \multicolumn{3}{|c|}{ 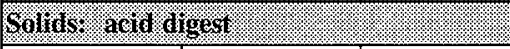 } & 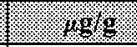 & 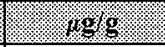 & 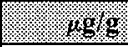 \\
\hline \$98T000695 & $223: 6$ & Whole & 167 & 202 & 185 \\
\hline \$98T000705 & $223: 6 \mathrm{~A}$ & Whole & 234 & 128 & $181^{\mathrm{QC}: e}$ \\
\hline \$98T000706 & $223: 9$ & Whole & 174 & 122 & $148^{\mathrm{QC}: \mathrm{e}}$ \\
\hline \$98T000721 & $224: 2$ & Whole & 141 & 78.5 & 110 \\
\hline$\$ 98 \mathrm{~T} 000722$ & $224: 4$ & Whole & 163 & 98.4 & $131^{\mathrm{QC}: \mathrm{e}}$ \\
\hline$\$ 98 \mathrm{~T} 000723$ & $224: 7$ & Whole & 148 & 163 & 156 \\
\hline \$98T000724 & $224: 10$ & Whole & 108 & 167 & $138^{\mathrm{QC}: \mathrm{e}}$ \\
\hline \multicolumn{2}{|c|}{ 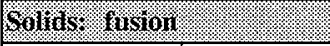 } & & f. & 106 & 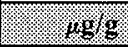 \\
\hline S97T002177 & $223: 1$ & Lower half & $<2,080$ & $<2,040$ & $<2,060$ \\
\hline S97T002185 & $223: 2$ & Lower half & $<1,920$ & $<1,890$ & $<1,910$ \\
\hline S97T002194 & $223: 3$ & Lower half & $<1,880$ & $<1,870$ & $<1,880$ \\
\hline \$97T002204 & $223: 4$ & Lower half & $<2,200$ & $<2,150$ & $<2,180$ \\
\hline S97T002231 & $223: 5$ & Lower half & $<1,840$ & $<1,900$ & $<1,870$ \\
\hline \$98T000694 & $223: 6$ & Whole & $<1,930$ & $<1,890$ & $<1,910$ \\
\hline S98T000703 & $223: 6 \mathrm{~A}$ & Whole & $<1,850$ & $<1,890$ & $<1,870$ \\
\hline \$97T002233 & \multirow[t]{2}{*}{$223: 7$} & Upper half & $<2,100$ & $<2,000$ & $<2,050$ \\
\hline \$97T002232 & & Lower half & $<1,960$ & $<2,030$ & $<2,000$ \\
\hline$\$ 97 \mathrm{~T} 002235$ & \multirow[t]{2}{*}{$223: 8$} & Upper half & $<2,030$ & $<2,020$ & $<2,030$ \\
\hline S97T002234 & & Lower half & $<1,980$ & $<2,010$ & $<2,000$ \\
\hline S98T000704 & 223:9 & Whole & $<2,020$ & $<2,040$ & $<2,030$ \\
\hline S97T002265 & \multirow[t]{2}{*}{$223: 10$} & Upper half & $<1,970$ & $<1,970$ & $<1,970$ \\
\hline S97T002263 & & Lower half & $<2,050$ & $<2,050$ & $<2,050$ \\
\hline S97T002320 & $224: 1$ & Lower half & $<1,900$ & $<1,850$ & $<1,880$ \\
\hline S98T000717 & $224: 2$ & Whole & $<2,020$ & $<1,950$ & $<1,990$ \\
\hline \$97T002334 & $224: 3$ & Lower half & $<1,830$ & $<1,850$ & $<1,840$ \\
\hline S98T000718 & $224: 4$ & Whole & $<2,010$ & $<1,990$ & $<2,000$ \\
\hline \$97T002360 & \multirow[t]{2}{*}{$224: 5$} & Upper half & $<2,000$ & $<2,040$ & $<2,020$ \\
\hline S97T002359 & & Lower half & $<2,020$ & $<2,000$ & $<2,010$ \\
\hline S97T002362 & \multirow[t]{2}{*}{$224: 6$} & Upper half & $<1,820$ & $<1,750$ & $<1,790$ \\
\hline S97T002361 & & Lower half & $<1,930$ & $<1,960$ & $<1,950$ \\
\hline
\end{tabular}


Table B2-17. Tank 241-SX-106 Analytical Results: Calcium (ICP). (2 sheets)

\begin{tabular}{|c|c|c|c|c|c|}
\hline Shample & $\begin{array}{l}\text { Sample } \\
\text { Lacation }\end{array}$ & $\begin{array}{l}\text { Sample } \\
\text { rorion. }\end{array}$ & Result & Bupliedte & Merin: \\
\hline \multicolumn{2}{|c|}{ Sands: Insion (cont d) } & 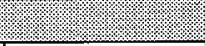 & 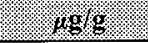 & 109.8 & 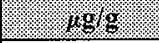 \\
\hline S98T000719 & $224: 7$ & Whole & 5,330 & $<2,000$ & $<3,670^{\mathrm{QC}: \mathrm{c}, \mathrm{e}}$ \\
\hline S97T002364 & \multirow[t]{2}{*}{$224: 8$} & Upper half & $<2,020$ & $<2,010$ & $<2,020$ \\
\hline S97T002363 & & Lower half & $<1,850$ & $<1,810$ & $<1,830$ \\
\hline S97T002392 & \multirow[t]{2}{*}{$224: 9$} & Upper half & $<2,190$ & $<2,190$ & $<2,190$ \\
\hline$\$ 97 \Upsilon 002387$ & & Lower half & $<2,230$ & $<2,240$ & $<2,240$ \\
\hline S98T000720 & $224: 10$ & Whole & $<1,960$ & $<1,950$ & $<1,960$ \\
\hline S97T002402 & \multirow[t]{2}{*}{$224: 11$} & Upper half & $<2,010$ & $<2,010$ & $<2,010$ \\
\hline S97T002397 & & Lower half & $<1,970$ & $<1,920$ & $<1,950$ \\
\hline \multicolumn{2}{|l|}{ Mavios: } & 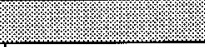 & 4.18010 & $1.981 \mathrm{mil}$ & $1.9 / \mathrm{m} 1$ \\
\hline S97T002179 & $223: 1$ & Drainable liquid & $<60.1$ & $<60.1$ & $<60.1$ \\
\hline S97T002188 & $223: 2$ & Drainable liquid & $<60.1$ & $<60.1$ & $<60.1$ \\
\hline S97T002199 & $223: 3$ & \begin{tabular}{|l|} 
Drainable liquid \\
\end{tabular} & $<60.1$ & $<60.1$ & $<60.1$ \\
\hline S97T002200 & $223: 4$ & Drainable liquid & $<60.1$ & $<60.1$ & $<60.1$ \\
\hline S97T002215 & $223: 5$ & Drainable liquid & $<60.1$ & $<60.1$ & $<60.1$ \\
\hline S97T002323 & 224:1 & Drainable liquid & $<60.1$ & $<60.1$ & $<60.1$ \\
\hline S97T002371 & $224: 3$ & Drainable liquid & $<60.1$ & $<60.1$ & $<60.1$ \\
\hline S97T002372 & $224: 5$ & Drainable liquid & $<60.1$ & $<60.1$ & $<60.1$ \\
\hline
\end{tabular}


Table B2-18. Tank 241-SX-106 Analytical Results: Cerium (ICP). (2 sheets)

\begin{tabular}{|c|c|c|c|c|c|}
\hline Suminie & \%ocringlo & Samule & Resilt & Buylicates & Mean \\
\hline \multicolumn{2}{|c|}{ 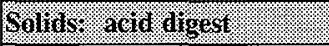 } & & $(1996$ & 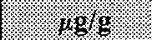 & 1696 \\
\hline \$98T000695 & $223: 6$ & Whole & $<40.1$ & $<37.6$ & $<38.9$ \\
\hline S98T000705 & $223: 6 \mathrm{~A}$ & Whole & $<37.5$ & $<39.3$ & $<38.4$ \\
\hline \$98T000706 & $223: 9$ & Whole & $<38$ & $<37.6$ & $<37.8$ \\
\hline S98T000721 & $224: 2$ & Whole & $<24.2$ & $<17.5$ & $<20.9$ \\
\hline S98T000722 & $224: 4$ & Whole & $<19.4$ & $<19.2$ & $<19.3$ \\
\hline \$98T000723 & $224: 7$ & Whole & $<39.3$ & $<38.8$ & $<39$ \\
\hline \$98T000724 & $224: 10$ & Whole & $<36$ & $<35.3$ & $<35.6$ \\
\hline \multicolumn{2}{|c|}{ Sold } & & .1098 & $\sqrt{10} 9$ & 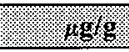 \\
\hline S97T002177 & $223: 1$ & Lower half & $<2,080$ & $<2,040$ & $<2,060$ \\
\hline S97T002185 & $223: 2$ & Lower half & $<1,920$ & $<1,890$ & $<1,910$ \\
\hline S97T002194 & $223: 3$ & Lower half & $<1,880$ & $<1,870$ & $<1,880$ \\
\hline$\$ 97 T 002204$ & $223: 4$ & Lower half & $<2,200$ & $<2,150$ & $<2,180$ \\
\hline S97T002231 & $223: 5$ & Lower half & $<1,840$ & $<1,900$ & $<1,870$ \\
\hline \$98T000694 & $223: 6$ & Whole & $<1,930$ & $<1,890$ & $<1,910$ \\
\hline \$98T000703 & 223:6A & Whole & $<1,850$ & $<1,890$ & $<1,870$ \\
\hline \$97T002233 & \multirow[t]{2}{*}{$223: 7$} & Upper half & $<2,100$ & $<2,000$ & $<2,050$ \\
\hline \$97T002232 & & Lower half & $<1,960$ & $<2,030$ & $<2,000$ \\
\hline S97T002235 & \multirow[t]{2}{*}{$223: 8$} & Upper half & $<2,030$ & $<2,020$ & $<2,030$ \\
\hline \$97T002234 & & Lower half & $<1,980$ & $<2,010$ & $<2,000$ \\
\hline S98T000704 & $223: 9$ & Whole & $<2,020$ & $<2,040$ & $<2,030$ \\
\hline S97T002265 & \multirow[t]{2}{*}{$223: 10$} & Upper half & $<1,970$ & $<1,970$ & $<1,970$ \\
\hline S97T002263 & & Lower half & $<2,050$ & $<2,050$ & $<2,050$ \\
\hline \$97T002320 & $224: 1$ & Lower half & $<1,900$ & $<1,850$ & $<1,880$ \\
\hline S98T000717 & $224: 2$ & Whole & $<2,020$ & $<1,950$ & $<1,990$ \\
\hline \$97T002334 & $224: 3$ & Lower half & $<1,830$ & $<1,850$ & $<1,840$ \\
\hline \$98T000718 & $224: 4$ & Whole & $<2,010$ & $<1,990$ & $<2,000$ \\
\hline \$97T002360 & \multirow[t]{2}{*}{$224: 5$} & Upper half & $<2,000$ & $<2,040$ & $<2,020$ \\
\hline \$97T002359 & & Lower half & $<2,020$ & $<2,000$ & $<2,010$ \\
\hline S97T002362 & \multirow[t]{2}{*}{$224: 6$} & Upper half & $<1,820$ & $<1,750$ & $<1,790$ \\
\hline S97T002361 & & Lower half & $<1,930$ & $<1,960$ & $<1,950$ \\
\hline
\end{tabular}


Table B2-18. Tank 241-SX-106 Analytical Results: Cerium (ICP). (2 sheets)

\begin{tabular}{|c|c|c|c|c|c|}
\hline Sampie & $\begin{array}{l}\text { Sanjile } \\
\text { I Eoration }\end{array}$ & $\begin{array}{l}\text { Sarrivile } \\
\text { Fortion }\end{array}$ & Resrilu & Boslinate & Mean \\
\hline \multicolumn{3}{|c|}{ Salias? fusion ( Cont d) } & 11038 & 1099 & 2.1099 \\
\hline S98T000719 & $224: 7$ & Whole & $<1,930$ & $<2,000$ & $<1,970$ \\
\hline S97T002364 & \multirow[t]{2}{*}{$224: 8$} & Upper half & $<2,020$ & $<2,010$ & $<2,020$ \\
\hline S97T002363 & & Lower half & $<1,850$ & $<1,810$ & $<1,830$ \\
\hline S97T002392 & \multirow[t]{2}{*}{$224: 9$} & Upper half & $<2,190$ & $<2,190$ & $<2,190$ \\
\hline S97T002387 & & Lower half & $<2,230$ & $<2,240$ & $<2,240$ \\
\hline S98T000720 & $224: 10$ & Whole & $<1,960$ & $<1,950$ & $<1,960$ \\
\hline S97T002402 & \multirow{2}{*}{$224: 11$} & Upper half & $<2,010$ & $<2,010$ & $<2,010$ \\
\hline S97T002397 & & Lower half & $<1,970$ & $<1,920$ & $<1,950$ \\
\hline Wrivias. & $l_{2.8}$ & (3.: & 189411 & $189 \ln 1$. & (3. \\
\hline S97T002179 & $223: 1$ & Drainable liquid & $<60.1$ & $<60.1$ & $<60.1$ \\
\hline S97T002188 & 223:2 & Drainable liquid & $<60.1$ & $<60.1$ & $<60.1$ \\
\hline S97T002199 & $223: 3$ & Drainable liquid & $<60.1$ & $<60.1$ & $<60.1$ \\
\hline S97T002200 & $223: 4$ & Drainable liquid & $<60.1$ & $<60.1$ & $<60.1$ \\
\hline S97T002215 & $223: 5$ & Drainable liquid & $<60.1$ & $<60.1$ & $<60.1$ \\
\hline S97T002323 & $224: 1$ & Drainable liquid & $<60.1$ & $<60.1$ & $<60.1$ \\
\hline S97T002371 & $224: 3$ & Drainable liquid & $<60.1$ & $<60.1$ & $<60.1$ \\
\hline S97T002372 & $224: 5$ & Drainable liquid & $<60.1$ & $<60.1$ & $<60.1$ \\
\hline
\end{tabular}


HNF-SD-WM-ER-645 Rev. 1

Table B2-19. Tank 241-SX-106 Analytical Results: Chromium (ICP). (2 sheets)

\begin{tabular}{|c|c|c|c|c|c|}
\hline samole & Sample & $\begin{array}{l}621018 \\
801401\end{array}$ & 20sulf & Boplicase & mernol \\
\hline \multicolumn{2}{|c|}{ 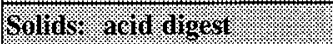 } & & $169 \%$ & 1.918 & 1498 \\
\hline \$98T000695 & $223: 6$ & Whole & 2,950 & 2,990 & 2,970 \\
\hline S98T000705 & $223: 6 \mathrm{~A}$ & Whole & 4,210 & 2,810 & $3,510^{\mathrm{QC}: \mathrm{c}, \mathrm{c}, \mathrm{h}}$ \\
\hline \$98T000706 & $223: 9$ & Whole & 2,810 & 2,700 & 2,760 \\
\hline$\$ 98 T 000721$ & $224: 2$ & Whole & 40.8 & 41.5 & 41.1 \\
\hline S98T000722 & $224: 4$ & Whole & 43.9 & 43.9 & 43.9 \\
\hline S98T000723 & $224: 7$ & Whole & 1,790 & 1,970 & $1,880^{\mathrm{QC}: \mathrm{c}}$ \\
\hline S98T000724 & $224: 10$ & Whole & 1,770 & 1,670 & 1,720 \\
\hline \multicolumn{2}{|c|}{ 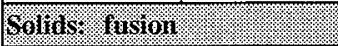 } & & . $10.7 \mathrm{~g}$ & 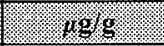 & 4.10919 \\
\hline S97T002177 & $223: 1$ & Lower half & $<208$ & $<204$ & $<206$ \\
\hline \$97T002185 & $223: 2$ & Lower half & $<192$ & $<189$ & $<191$ \\
\hline \$97T002194 & $223: 3$ & Lower half & $<188$ & $<187$ & $<188$ \\
\hline S97T002204 & $223: 4$ & Lower half & 531 & 360 & $446^{\mathrm{QC}: \mathrm{c}}$ \\
\hline S97T002231 & $223: 5$ & Lower half & 947 & 1,070 & 1,010 \\
\hline S98T000694 & $223: 6$ & Whole & 2,910 & 2,930 & 2,920 \\
\hline S98T000703 & $223: 6 \mathrm{~A}$ & Whole & 3,900 & 4,060 & 3,980 \\
\hline \$97T002233 & \multirow[t]{2}{*}{$223: 7$} & Upper half & 9,850 & 9,730 & 9,790 \\
\hline S97T002232 & & Lower half & 8,060 . & 8,380 & 8,220 \\
\hline S97T002235 & \multirow[t]{2}{*}{$223: 8$} & Upper half & 3,780 & 3,770 & 3,780 \\
\hline S97T002234 & & Lower half & 2,740 & 2,870 & 2,810 \\
\hline S98T000704 & $223: 9$ & Whole & 2,670 & 3,350 & $3,010^{\mathrm{QC}: \mathrm{e}}$ \\
\hline$\$ 97 \mathrm{~T} 002265$ & \multirow[t]{2}{*}{$223: 10$} & Upper half & 4,510 & 4,760 & 4,640 \\
\hline \$97T002263 & & Lower half & 6,160 & 5,970 & 6,070 \\
\hline S97T002320 & $224: 1$ & Lower half & $<190$ & $<185$ & $<188$ \\
\hline \$98T000717 & $224: 2$ & Whole & $<202$ & $<195$ & $<199$ \\
\hline S97T002334 & $224: 3$ & Lower half & $<183$ & $<185$ & $<184$ \\
\hline S98T000718 & $224: 4$ & Whole & $<201$ & $<199$ & $<200$ \\
\hline S97T002360 & \multirow[t]{2}{*}{$224: 5$} & Upper half & 496 & 475 & 486 \\
\hline S97T002359 & & Lower half & 7,230 & 8,040 & 7,640 \\
\hline \$97T002362 & \multirow[t]{2}{*}{$224: 6$} & Upper half & 8,150 & 8,540 & 8,350 \\
\hline S97T002361 & & Lower half & 8,400 & 8,750 & 8,580 \\
\hline
\end{tabular}


Table B2-19. Tank 241-SX-106 Analytical Results: Chromium (ICP). (2 sheets)

\begin{tabular}{|c|c|c|c|c|c|}
\hline Sample & $\begin{array}{l}\text { Sample } \\
\text { Location }\end{array}$ & $\begin{array}{l}\text { Sariple } \\
\text { Prortion: }\end{array}$ & Resuil & Buplucate & .961 \\
\hline \multicolumn{2}{|c|}{ Soltis: fusion (Coni d) } & 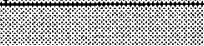 & $1,104 \mathrm{~g}$ & 1,198 & 1,898 \\
\hline S98T000719 & $224: 7$ & Whole & 2,130 & 2,260 & 2,200 \\
\hline S97T002364 & \multirow[t]{2}{*}{$224: 8$} & Upper half & 7,290 & 7,970 & 7,630 \\
\hline S97T002363 & & Lower half & 8,030 & 7,470 & 7,750 \\
\hline S97T002392 & \multirow[t]{2}{*}{$224: 9$} & Upper half & 4,310 & 4,230 & 4,270 \\
\hline S97T002387 & & Lower half & 9,010 & 8,420 & 8,720 \\
\hline S98T000720 & $224: 10$ & Whole & 2,450 & 2,000 & $2,230^{\mathrm{QC}: c}$ \\
\hline S97T002402 & \multirow[t]{2}{*}{$224: 11$} & Upper half & 4,450 & 4,500 & 4,480 \\
\hline S97T002397 & & Lower half & 5,920 & 5,890 & 5,910 \\
\hline Lruids: & 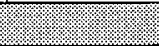 & (3) & 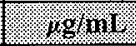 & $109 / 101$ & $.181 \mathrm{mI}$ \\
\hline S97T002179 & $223: 1$ & Drainable liquid & 131 & 127 & 129 \\
\hline S97T002188 & $223: 2$ & Drainable liquid & 130 & 122 & 126 \\
\hline S97T002199 & $223: 3$ & Drainable liquid & 136 & 135 & 136 \\
\hline S97T002200 & $223: 4$ & Drainable liquid & 139 & 135 & 137 \\
\hline S97T002215 & $223: 5$ & Drainable liquid & 135 & 132 & 134 \\
\hline S97T002323 & $224: 1$ & Drainable liquid & 135 & 136 & 136 \\
\hline S97T002371 & $224: 3$ & Drainable liquid & 128 & 131 & 130 \\
\hline S97T002372 & $224: 5$ & Drainable liquid & 111 & 110 & 111 \\
\hline
\end{tabular}


HNF-SD-WM-ER-645 Rev. 1

Table B2-20. Tank 241-SX-106 Analytical Results: Cobalt (ICP). (2 sheets)

\begin{tabular}{|c|c|c|c|c|c|}
\hline $\begin{array}{l}\text { Sample } \\
\text { Nimber }\end{array}$ & $\begin{array}{l}\text { Sample. } \\
\text { Location }\end{array}$ & $\begin{array}{l}\text { Sample } \\
\text { roortion }\end{array}$ & Resula & Buplicare & Mean. \\
\hline \multicolumn{2}{|c|}{ S. Solits ard digest ? } & 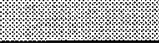 & 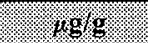 & 498 & 10919 \\
\hline S98T000695 & $223: 6$ & Whole & $<8.03$ & $<7.52$ & $<7.78$ \\
\hline S98T000705 & $223: 6 \mathrm{~A}$ & Whole & $<7.5$ & $<7.86$ & $<7.68$ \\
\hline S98T000706 & $223: 9$ & Whole & $<7.6$ & $<7.52$ & $<7.56$ \\
\hline S98T000721 & $224: 2$ & Whole & $<4.84$ & $<3.51$ & $<4.18$ \\
\hline S98T000722 & $224: 4$ & Whole & $<3.89$ & $<3.83$ & $<3.86$ \\
\hline S98T000723 & $224: 7$ & Whole & $<7.86$ & $<7.76$ & $<7.81$ \\
\hline S98T000724 & $224: 10$ & Whole & $<3.6$ & $<3.53$ & $<3.56$ \\
\hline Solids. Tinsion & 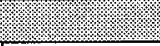 & 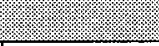 & 4.1890 & $4.9898=$ & 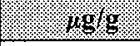 \\
\hline S97T002177 & $223: 1$ & Lower half & $<416$ & $<407$ & $<412$ \\
\hline S97T002185 & $223: 2$ & Lower half & $<383$ & $<378$ & $<381$ \\
\hline S97T002194 & $223: 3$ & Lower half & $<376$ & $<373$ & $<375$ \\
\hline S97T002204 & $223: 4$ & Lower half & $<440$ & $<430$ & $<435$ \\
\hline S97T002231 & $223: 5$ & Lower half & $<369$ & $<380$ & $<375$ \\
\hline S98T000694 & $223: 6$ & Whole & $<386$ & $<378$ & $<382$ \\
\hline S98T000703 & 223:6A & Whole & $<370$ & $<377$ & $<374$ \\
\hline S97T002233 & \multirow[t]{2}{*}{$223: 7$} & Upper half & $<420$ & $<401$ & $<411$ \\
\hline S97T002232 & & Lower half & $<392$ & $<406$ & $<399$ \\
\hline S97T002235 & \multirow[t]{2}{*}{$223: 8$} & Upper half & $<405$ & $<404$ & $<405$ \\
\hline S97T002234 & & Lower half & $<397$ & $<401$ & $<399$ \\
\hline S98T000704 & $223: 9$ & Whole & $<404$ & $<408$ & $<406$ \\
\hline S97T002265 & \multirow[t]{2}{*}{$223: 10$} & Upper half & $<394$ & $<393$ & $<394$ \\
\hline S97T002263 & & Lower half & $<410$ & $<410$ & $<410$ \\
\hline S97T002320 & $224: 1$ & Lower half & $<380$ & $<369$ & $<375$ \\
\hline S98T000717 & $224: 2$ & Whole & $<405$ & $<390$ & $<398$ \\
\hline S97T002334 & $224: 3$ & Lower half & $<366$ & $<369$ & $<368$ \\
\hline S98T000718 & $224: 4$ & Whole & $<403$ & $<398$ & $<401$ \\
\hline S97T002360 & \multirow[t]{2}{*}{$224: 5$} & Upper half & $<400$ & $<407$ & $<404$ \\
\hline S97T002359 & & Lower half & $<404$ & $<400$ & $<402$ \\
\hline S97T002362 & \multirow[t]{2}{*}{$224: 6$} & Upper half & $<364$ & $<349$ & $<357$ \\
\hline S97T002361 & & Lower half & $<387$ & $<391$ & $<389$ \\
\hline
\end{tabular}


Table B2-20. Tank 241-SX-106 Analytical Results: Cobalt (ICP). (2 sheets)

\begin{tabular}{|c|c|c|c|c|c|}
\hline $\begin{array}{l}\text { Sample } \\
\text { Nimber }\end{array}$ & $\begin{array}{l}\text { Samole } \\
\text { Uocation }\end{array}$ & $\begin{array}{l}\text { Sample } \\
\text { Iortion } \\
\end{array}$ & mesinit) & ouphicares & ingan \\
\hline \multicolumn{2}{|c|}{ 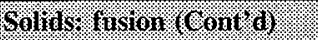 } & 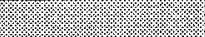 & $10 \mathrm{~g} / 2$ & (1) $19 \%$ & $=1 \mathrm{rg} / \mathrm{g}$ \\
\hline S98T000719 & $224: 7$ & Whole & $<387$ & $<400$ & $<394$ \\
\hline S97T002364 & \multirow[t]{2}{*}{$224: 8$} & Upper half & $<404$ & $<401$ & $<403$ \\
\hline S97T002363 & & Lower half & $<369$ & $<362$ & $<366$ \\
\hline S97T002392 & \multirow[t]{2}{*}{$224: 9$} & Upper half & $<437$ & $<438$ & $<438$ \\
\hline S97T002387 & & Lower half & $<447$ & $<448$ & $<448$ \\
\hline S98T000720 & $224: 10$ & Whole & $<393$ & $<390$ & $<392$ \\
\hline S97T002402 & \multirow[t]{2}{*}{$224: 11$} & Upper half & $<402$ & $<401$ & $<402$ \\
\hline S97T002397 & & Lower half & $<394$ & $<385$ & $<390$ \\
\hline \multicolumn{2}{|c|}{ Erruts } & (2) & $1.98101 \%$ & $109 \mathrm{~mol}$ & $4.8 \mathrm{gma}$ \\
\hline S97T002179 & $223: 1$ & Drainable liquid & $<12$ & $<12$ & $<12$ \\
\hline S97T002188 & $223: 2$ & Drainable liquid & $<12$ & $<12$ & $<12$ \\
\hline S97T002199 & $223: 3$ & Drainable liquid & $<12$ & $<12$ & $<12$ \\
\hline S97T002200 & $223: 4$ & Drainable liquid & $<12$ & $<12$ & $<12$ \\
\hline S97T002215 & $223: 5$ & Drainable liquid & $<12$ & $<12$ & $<12$ \\
\hline S97T002323 & $224: 1$ & Drainable liquid & $<12$ & $<12$ & $<12$ \\
\hline S97T002371 & $224: 3$ & Drainable liquid & $<12$ & $<12$ & $<12$ \\
\hline S97T002372 & $224: 5$ & Drainable liquid & $<12$ & $<12$ & $<12$ \\
\hline
\end{tabular}


Table B2-21. Tank 241-SX-106 Analytical Results: Copper (ICP). (2 sheets)

\begin{tabular}{|c|c|c|c|c|c|}
\hline $\begin{array}{l}\text { Sannile } \\
\text { Nunber }\end{array}$ & $\begin{array}{l}\text { Sample } \\
\text { Inocation }\end{array}$ & $\begin{array}{l}\text { Sample } \\
\text { eortion }\end{array}$ & Result: & Eriviluato & Men \\
\hline \multicolumn{2}{|c|}{ Solids acidagest } & & 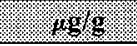 & $1.96 \mathrm{~g}$ & (1) \\
\hline \$98T000695 & $223: 6$ & Whole & $<4.01$ & $<3.76$ & $<3.88$ \\
\hline S98T000705 & $223: 6 \mathrm{~A}$ & Whole & $<3.75$ & $<3.93$ & $<3.84$ \\
\hline S98T000706 & $223: 9$ & Whole & $<3.8$ & $<3.76$ & $<3.78$ \\
\hline S98T000721 & $224: 2$ & Whole & $<2.42$ & $<1.75$ & $<2.08$ \\
\hline$\$ 98 T 000722$ & $224: 4$ & Whole & $<1.94$ & $<1.92$ & $<1.93$ \\
\hline S98T000723 & $224: 7$ & Whole & $<3.93$ & $<3.88$ & $<3.91$ \\
\hline S98T000724 & $224: 10$ & Whole & $<3.6$ & $<3.53$ & $<3.56$ \\
\hline \multicolumn{2}{|c|}{ Solids: fusion : } & (3.:3: & 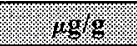 & $109 \mathrm{~g}$ & 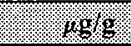 \\
\hline S97T002177 & $223: 1$ & Lower half & $<208$ & $<204$ & $<206$ \\
\hline S97T002185 & $223: 2$ & Lower half & $<192$ & $<189$ & $<191$ \\
\hline S97T002194 & $223: 3$ & Lower half & $<188$ & $<187$ & $<188$ \\
\hline$\$ 97 T 002204$ & $223: 4$ & Lower half & $<220$ & $<215$ & $<218$ \\
\hline S97T002231 & $223: 5$ & Lower half & $<184$ & $<190$ & $<187$ \\
\hline S98T000694 & $223: 6$ & Whole & $<193$ & $<189$ & $<191$ \\
\hline S98T000703 & $223: 6 \mathrm{~A}$ & Whole & $<185$ & $<189$ & $<187$ \\
\hline S97T002233 & \multirow[t]{2}{*}{$223: 7$} & Upper half & $<210$ & $<200$ & $<205$ \\
\hline S97T002232 & & Lower half & $<196$ & $<203$ & $<200$ \\
\hline S97T002235 & \multirow[t]{2}{*}{$223: 8$} & Upper half & $<203$ & $<202$ & $<203$ \\
\hline S97T002234 & & Lower half & $<198$ & $<201$ & $<200$ \\
\hline S98T000704 & $223: 9$ & Whole & $<202$ & $<204$ & $<203$ \\
\hline S97T002265 & \multirow[t]{2}{*}{$223: 10$} & Upper half & $<197$ & $<197$ & $<197$ \\
\hline S97T002263 & & Lower half & $<205$ & $<205$ & $<205$ \\
\hline S97T002320 & $224: 1$ & Lower half & $<190$ & $<185$ & $<188$ \\
\hline S98T000717 & $224: 2$ & Whole & $<202$ & $<195$ & $<199$ \\
\hline S97T002334 & $224: 3$ & Lower half & $<183$ & $<185$ & $<184$ \\
\hline \begin{tabular}{|l|} 
S98T000718 \\
\end{tabular} & $224: 4$ & \begin{tabular}{|l|} 
Whole \\
\end{tabular} & $<201$ & $<199$ & $<200$ \\
\hline S97T002360 & \multirow[t]{2}{*}{$224: 5$} & Upper half & $<200$ & $<204$ & $<202$ \\
\hline S97T002359 & & Lower half & $<202$ & $<200$ & $<201$ \\
\hline S97T002362 & \multirow[t]{2}{*}{$224: 6$} & Upper half & $<182$ & $<175$ & $<179$ \\
\hline S97T002361 & & Lower half & $<193$ & $<196$ & $<195$ \\
\hline
\end{tabular}


HNF-SD-WM-ER-645 Rev. 1

Table B2-21. Tank 241-SX-106 Analytical Results: Copper (ICP). (2 sheets)

\begin{tabular}{|c|c|c|c|c|c|}
\hline Sample. & 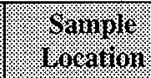 & $.5 \%$ mole & Resulin & Durnirate & Mear \\
\hline \multicolumn{2}{|c|}{ 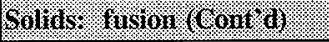 } & 1. & 1.919 & 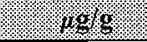 & 1408 \\
\hline S98T000719 & $224: 7$ & Whole & $<193$ & $<200$ & $<197$ \\
\hline S97T002364 & \multirow[t]{2}{*}{$224: 8$} & Upper half & $<202$ & $<201$ & $<202$ \\
\hline S97T002363 & & Lower half & $<185$ & $<181$ & $<183$ \\
\hline S97T002392 & \multirow[t]{2}{*}{$224: 9$} & Upper half & $<219$ & $<219$ & $<219$ \\
\hline S97T002387 & & Lower half & $<223$ & $<224$ & $<224$ \\
\hline S98T000720 & $224: 10$ & Whole & $<196$ & $<195$ & $<196$ \\
\hline S97T002402 & \multirow[t]{2}{*}{$224: 11$} & Upper half & $<201$ & $<201$ & $<201$ \\
\hline S97T002397 & & Lower half & $<197$ & $<192$ & $<195$ \\
\hline \multicolumn{2}{|l|}{ Bundus } & ל. & 14961 & 6.962101 & .0 .911 \\
\hline S97T002179 & $223: 1$ & Drainable liquid & $<6.01$ & $<6.01$ & $<6.01$ \\
\hline S97T002188 & $223: 2$ & Drainable liquid & $<6: 01$ & $<6.01$ & $<6.01$ \\
\hline S97T002199 & $223: 3$ & Drainable liquid & $<6.01$ & $<6.01$ & $<6.01$ \\
\hline S97T002200 & $223: 4$ & Drainable liquid & $<6.01$ & $<6.01$ & $<6.01$ \\
\hline S97T002215 & $223: 5$ & Drainable liquid & $<6.01$ & $<6.01$ & $<6.01$ \\
\hline S97T002323 & $224: 1$ & Drainable liquid & $<6.01$ & $<6.01$ & $<6.01$ \\
\hline S97T002371 & $224: 3$ & Drainable liquid & $<6.01$ & $<6.01$ & $<6.01$ \\
\hline S97T002372 & $224: 5$ & Drainable liquid & $<6.01$ & $<6.01$ & $<6.01$ \\
\hline
\end{tabular}


Table B2-22. Tank 241-SX-106 Analytical Results: Iron (ICP). (2 sheets)

\begin{tabular}{|c|c|c|c|c|c|}
\hline Samion & 6arnule & 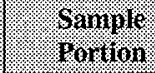 & Resurt & Irolicale & Meran \\
\hline \multicolumn{2}{|c|}{ Sollost acid digest. } & & $16 \mathrm{~g} 8$ & 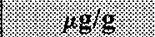 & 6.9. \\
\hline S98T000695 & $223: 6$ & Whole & 355 & 359 & 357 \\
\hline S98T000705 & $223: 6 \mathrm{~A}$ & Whole & 554 & 415 & $485^{\mathrm{QC}: \mathrm{e}}$ \\
\hline S98T000706 & $223: 9$ & Whole & 415 & 399 & 407 \\
\hline S98T000721 & $224: 2$ & Whole & $<12.1$ & $<8.76$ & $<10.4$ \\
\hline S98T000722 & $224: 4$ & Whole & 12 & $<9.58$ & $<10.8^{\mathrm{QC:e}}$ \\
\hline S98T000723 & $224: 7$ & Whole & 234 & 260 & 247 \\
\hline S98T000724 & $224: 10$ & Whole & 885 & 839 & 862 \\
\hline \multicolumn{2}{|c|}{ Solims. Wuston: } & 3. & \% & . & was \\
\hline S97T002177 & $223: 1$ & Lower half & $<1,040$ & $<1,020$ & $<1,030$ \\
\hline S97T002185. & $223: 2$ & Lower half & $<958$ & $<946$ & $<952$ \\
\hline S97T002194 & $223: 3$ & Lower half & $<939$ & $<934$ & $<937$ \\
\hline S97T002204 & $223: 4$ & Lower half & $<1,100$ & $<1,070$ & $<1,090$ \\
\hline S97T002231 & $223: 5$ & Lower half & $<922$ & $<951$ & $<937$ \\
\hline S98T000694 & $223: 6$ & Whole & $<965$ & $<946$ & $<956$ \\
\hline S98T000703 & $223: 6 \mathrm{~A}$ & Whole & $<926$ & $<943$ & $<935$ \\
\hline S97T002233 & \multirow[t]{2}{*}{$223: 7$} & Upper half & 1,310 & 1,140 & 1,230 \\
\hline S97T002232 & & Lower half & $<979$ & $<1,010$ & $<995$ \\
\hline S97T002235 & \multirow[t]{2}{*}{$223: 8$} & Upper half & $<1,010$ & $<1,010$ & $<1,010$ \\
\hline S97T002234 & & Lower half & $<992$ & $<1,000$ & $<996$ \\
\hline S98T000704 & $223: 9$ & Whole & $<1,010$ & $<1,020$ & $<1,020$ \\
\hline S97T002265 & \multirow[t]{2}{*}{$223: 10$} & Upper half & $<985$ & $<984$ & $<985$ \\
\hline S97T002263 & & Lower half & 1,290 & 1,240 & 1,270 \\
\hline S97T002320 & $224: 1$ & Lower half & $<950$ & $<923$ & $<937$ \\
\hline S98T000717 & $224: 2$ & Whole & $<1,010$ & $<976$ & $<993$ \\
\hline S97T002334 & $224: 3$ & Lower half & $<914$ & $<923$ & $<919$ \\
\hline S98T000718 & $224: 4$ & Whole & $<1,010$ & $<995$ & $<1,000$ \\
\hline S97T002360 & \multirow[t]{2}{*}{$224: 5$} & Upper half & $<999$ & $<1,020$ & $<1,010$ \\
\hline \$97T002359 & & Lower half & $<1,010$ & $<999$ & $<1,000$ \\
\hline \$97T002362 & \multirow[t]{2}{*}{$224: 6$} & Upper half & $<910$ & $<873$ & $<892$ \\
\hline S97T002361 & & Lower half & $<967$ & $<978$ & $<973$ \\
\hline
\end{tabular}


Table B2-22. Tank 241-SX-106 Analytical Results: Iron (ICP). (2 sheets)

\begin{tabular}{|c|c|c|c|c|c|}
\hline $\begin{array}{l}\text { Sample } \\
\text { Number }\end{array}$ & $\begin{array}{l}\text { Sample } \\
\text { I ocation }\end{array}$ & $\begin{array}{l}\text { Samiple } \\
\text { Portion }\end{array}$ & Resull & Juplieate & Mean \\
\hline \multicolumn{2}{|c|}{ Solith? fusion (Cont a) ? } & 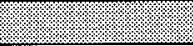 & 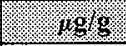 & 1. & 1898 \\
\hline S98T000719 & $224: 7$ & Whole & $<967$ & $<999$ & $<983$ \\
\hline S97T002364 & \multirow[t]{2}{*}{$224: 8$} & Upper half & 1,180 & 1,510 & $1,350^{\mathrm{QC:e}}$ \\
\hline S97T002363 & & Lower half & 1,080 & 971 & 1,030 \\
\hline S97T002392 & \multirow[t]{2}{*}{$224: 9$} & Upper half & $<1,090$ & $<1,100$ & $<1,100$ \\
\hline S97T002387 & & Lower half & 1,960 & 1,820 & 1,890 \\
\hline S98T000720 & $224: 10$ & Whole & $<982$ & $<976$ & $<979$ \\
\hline S97T002402 & \multirow[t]{2}{*}{$224: 11$} & Upper half & 1,840 & 1,960 & 1,900 \\
\hline S97イ002397 & & Lower half & 3,980 & 3,910 & 3,950 \\
\hline \multicolumn{2}{|l|}{ Miginds: } & : & .69113 & $.189 \mathrm{nt}$ & 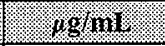 \\
\hline S97T002179 & $223: 1$ & Drainable liquid & $<30.1$ & $<30.1$ & $<30.1$ \\
\hline S97T002188 & $223: 2$ & Drainable liquid & $<30.1$ & $<30.1$ & $<30.1$ \\
\hline S97T002199 & $223: 3$ & Drainable liquid & $<30.1$ & $<30.1$ & $<30.1$ \\
\hline S97T002200 & $223: 4$ & Drainable liquid & $<30.1$ & $<30.1$ & $<30.1$ \\
\hline S97T002215 & $223: 5$ & Drainable liquid & $<30.1$ & $<30.1$ & $<30.1$ \\
\hline S97T002323 & $224: 1$ & Drainable liquid & $<30.1$ & $<30.1$ & $<30.1$ \\
\hline S97T002371 & $224: 3$ & Drainable liquid & $<30.1$ & $<30.1$ & $<30.1$ \\
\hline S97T002372 & $224: 5$ & Drainable liquid & $<30.1$ & $<30.1$ & $<30.1$ \\
\hline
\end{tabular}


Table B2-23. Tank 241-SX-106 Analytical Results: Lanthanum (ICP). (2 sheets)

\begin{tabular}{|c|c|c|c|c|c|}
\hline Samule & Srungle & Sample & Resulu & Dupligate & Mern \\
\hline \multicolumn{2}{|c|}{ Solidst act diygest } & 灰 & 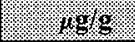 & glo & 1498 \\
\hline S98T000695 & $223: 6$ & Whole & $<20.1$ & $<18.8$ & $<19.5$ \\
\hline S98T000705 & $223: 6 \mathrm{~A}$ & Whole & $<18.7$ & $<19.6$ & $<19.1$ \\
\hline S98T000706 & $223: 9$ & Whole & $<19$ & $<18.8$ & $<18.9$ \\
\hline S98T000721 & $224: 2$ & Whole & $<12.1$ & $<8.76$ & $<10.4$ \\
\hline S98T000722 & $224: 4$ & Whole & $<9.72$ & $<9.58$ & $<9.65$ \\
\hline S98T000723 & $224: 7$ & Whole & $<19.7$ & $<19.4$ & $<19.5$ \\
\hline S98T000724 & $224: 10$ & Whole & $<18$ & $<17.7$ & $<17.9$ \\
\hline \multicolumn{2}{|l|}{ Solits . usion. } & & . & 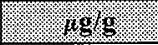 & 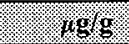 \\
\hline S97T002177 & $223: 1$ & Lower half & $<1,040$ & $<1,020$ & $<1,030$ \\
\hline S97T002185 & $223: 2$ & Lower half & $<958$ & $<946$ & $<952$ \\
\hline \$97T002194 & $223: 3$ & Lower half & $<939$ & $<934$ & $<937$ \\
\hline \$97T002204 & $223: 4$ & Lower half & $<1,100$ & $<1,070$ & $<1,090$ \\
\hline S97T002231 & $223: 5$ & Lower half & $<922$ & $<951$ & $<937$ \\
\hline S98T000694 & $223: 6$ & Whole & $<965$ & $<946$ & $<956$ \\
\hline S98T000703 & $223: 6 \mathrm{~A}$ & Whole & $<926$ & $<943$ & $<935$ \\
\hline \$97T002233 & \multirow[t]{2}{*}{$223: 7$} & Upper half & $<1,050$ & $<1,000$ & $<1,030$ \\
\hline S97T002232 & & Lower half & $<979$ & $<1,010$ & $<995$ \\
\hline S97T002235 & \multirow[t]{2}{*}{$223: 8$} & Upper half & $<1,010$ & $<1,010$ & $<1,010$ \\
\hline S97T002234 & & Lower half & $<992$ & $<1,000$ & $<996$ \\
\hline \$98T000704 & $223: 9$ & Whole & $<1,010$ & $<1,020$ & $<1,020$ \\
\hline S97T002265 & \multirow[t]{2}{*}{$223: 10$} & Upper half & $<985$ & $<984$ & $<985$ \\
\hline S97T002263 & & Lower half & $<1,020$ & $<1,030$ & $<1,030$ \\
\hline S97T002320 & $224: 1$ & Lower half & $<950$ & $<923$ & $<937$ \\
\hline \$98T000717 & $224: 2$ & Whole & $<1,010$ & $<976$ & $<993$ \\
\hline S97T002334 & $224: 3$ & Lower half & $<914$ & $<923$ & $<919$ \\
\hline S98T000718 & $224: 4$ & Whole & $<1,010$ & $<995$ & $<1,000$ \\
\hline S97T002360 & \multirow[t]{2}{*}{$224: 5$} & Upper half & $<999$ & $<1,020$ & $<1,010$ \\
\hline S97T002359 & & Lower half & $<1,010$ & $<999$ & $<1,000$ \\
\hline S97T002362 & \multirow[t]{2}{*}{$224: 6$} & Upper half & $<910$ & $<873$ & $<892$ \\
\hline S97T002361 & & Lower half & $<967$ & $<978$ & $<973$ \\
\hline
\end{tabular}


Table B2-23. Tank 241-SX-106 Analytical Results: Lanthanum (ICP). (2 sheets)

\begin{tabular}{|c|c|c|c|c|c|}
\hline Wample. & Wrante & . & iesuly & 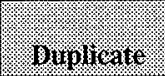 & Tern \\
\hline \multicolumn{3}{|c|}{ 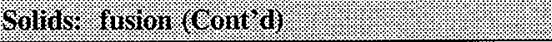 } & 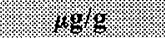 & $4.1 .1 .9 \mathrm{gra}$ & 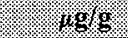 \\
\hline S98T000719 & $224: 7$ & Whole & $<967$ & $<999$ & $<983$ \\
\hline S97T002364 & \multirow[t]{2}{*}{$224: 8$} & Upper half & $<1,010$ & $<1,000$ & $<1,010$ \\
\hline S97T002363 & & Lower half & $<923$ & $<905$ & $<914$ \\
\hline S97T002392 & \multirow[t]{2}{*}{$224: 9$} & Upper half & $<1,090$ & $<1,100$ & $<1,100$ \\
\hline S97T002387 & & Lower half & $<1,120$ & $<1,120$ & $<1,120$ \\
\hline S98T000720 & $224: 10$ & Whole & $<982$ & $<976$ & $<979$ \\
\hline S97T002402 & \multirow[t]{2}{*}{$224: 11$} & Upper half & $<1,010$ & $<1,000$ & $<1,010$ \\
\hline \$97T002397 & & Lower half & $<984$ & $<962$ & $<973$ \\
\hline \multicolumn{3}{|l|}{ Equings, } & 110.1010 & $12.29 \% 13$ & \% \\
\hline S97T002179 & 223:1 & Drainable liquid & $<30.1$ & $<30.1$ & $<30.1$ \\
\hline \$97T002188 & $223: 2$ & Drainable liquid & $<30.1$ & $<30.1$ & $<30.1$ \\
\hline S97T002199 & $223: 3$ & Drainable liquid & $<30.1$ & $<30.1$ & $<30.1$ \\
\hline S97T002200 & $223: 4$ & Drainable liquid & $<30.1$ & $<30.1$ & $<30.1$ \\
\hline \$97T002215 & $223: 5$ & Drainable liquid & $<30.1$ & $<30.1$ & $<30.1$ \\
\hline S97T002323 & $224: 1$ & Drainable liquid & $<30.1$ & $<30.1$ & $<30.1$ \\
\hline S97T002371 & $224: 3$ & Drainable liquid & $<30.1$ & $<30.1$ & $<30.1$ \\
\hline \$97T002372 & $224: 5$ & Drainable liquid & $<30.1$ & $<30.1$ & $<30.1$ \\
\hline
\end{tabular}


Table B2-24. Tank 241-SX-106 Analytical Results: Lead (ICP). (2 sheets)

\begin{tabular}{|c|c|c|c|c|c|}
\hline Gaimule & 6range & Pamplo & resulu & Subsure & 4heran \\
\hline \multicolumn{2}{|c|}{ Solints arod groest } & (2:-2:- & 1896 & 1498 & 1498 \\
\hline S98T000695 & $223: 6$ & Whole & $<40.1$ & 49 & $<44.5$ \\
\hline S98T000705 & $223: 6 A$ & Whole & 59.5 & $<39.3$ & $<49.4^{\mathrm{QC}: \mathrm{e}}$ \\
\hline S98T000706 & $223: 9$ & Whole & 38.5 & $<37.6$ & $<38$ \\
\hline S98T000721 & $224: 2$ & Whole & $<24.2$ & $<17.5$ & $<20.9$ \\
\hline S98T000722 & $224: 4$ & Whole & $<19.4$ & $<19.2$ & $<19.3$ \\
\hline S98T000723 & $224: 7$ & Whole & $<39.3$ & $<38.8$ & $<39$ \\
\hline S98T000724 & $224: 10$ & Whole & 56.2 & 56.8 & 56.5 \\
\hline \multicolumn{2}{|l|}{ 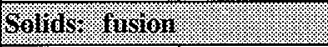 } & \% & $4.49 \%$ & .298 & 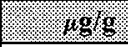 \\
\hline S97T002177 & $223: 1$ & Lower half & $<2,080$ & $<2,040$ & $<2,060$ \\
\hline S97T002185 & $223: 2$ & Lower half & $<1,920$ & $<1,890$ & $<1,910$ \\
\hline S97T002194 & $223: 3$ & Lower half & $<1,880$ & $<1,870$ & $<1,880$ \\
\hline S97T002204 & $223: 4$ & Lower half & $<2,200$ & $<2,150$ & $<2,180$ \\
\hline S97T002231 & $223: 5$ & Lower half & $<1,840$ & $<1,900$ & $<1,870$ \\
\hline \$98T000694 & $223: 6$ & Whole & $<1,930$ & $<1,890$ & $<1,910$ \\
\hline S98T000703 & $223: 6 \mathrm{~A}$ & Whole & $<1,850$ & $<1,890$ & $<1,870$ \\
\hline S97T002233 & \multirow[t]{2}{*}{$223: 7$} & Upper half & $<2,100$ & $<2,000$ & $<2,050$ \\
\hline S97T002232 & & Lower half & $<1,960$ & $<2,030$ & $<2,000$ \\
\hline S97T002235 & \multirow[t]{2}{*}{$223: 8$} & Upper half & $<2,030$ & $<2,020$ & $<2,030$ \\
\hline S97T002234 & & Lower half & $<1,980$ & $<2,010$ & $<2,000$ \\
\hline \$98T000704 & $223: 9$ & Whole & $<2,020$ & $<2,040$ & $<2,030$ \\
\hline S97T002265 & \multirow[t]{2}{*}{$223: 10$} & Upper half & $<1,970$ & $<1,970$ & $<1,970$ \\
\hline S97T002263 & & Lower half & $<2,050$ & $<2,050$ & $<2,050$ \\
\hline S97T002320 & $224: 1$ & Lower half & $<1,900$ & $<1,850$ & $<1,880$ \\
\hline S98T000717 & $224: 2$ & Whole & $<2,020$ & $<1,950$ & $<1,990$ \\
\hline S97T002334 & $224: 3$ & Lower half & $<1,830$ & $<1,850$ & $<1,840$ \\
\hline S98T000718 & $224: 4$ & Whole & $<2,010$ & $<1,990$ & $<2,000$ \\
\hline S97T002360 & \multirow[t]{2}{*}{$224: 5$} & Upper half & $<2,000$ & $<2,040$ & $<2,020$ \\
\hline S97T002359 & & Lower half & $<2,020$ & $<2,000$ & $<2,010$ \\
\hline \$97T002362 & \multirow[t]{2}{*}{$224: 6$} & Upper half & $<1,820$ & $<1,750$ & $<1,790$ \\
\hline S97T002361 & & Lower half & $<1,930$ & $<1,960$ & $<1,950$ \\
\hline
\end{tabular}


Table B2-24. Tank 241-SX-106 Analytical Results: Lead (ICP). (2 sheets)

\begin{tabular}{|c|c|c|c|c|c|}
\hline Sample & Sample & $\begin{array}{l}\text { Sample. } \\
\text { Porrion. }\end{array}$ & Resulit & Droblinate & Herin. \\
\hline \multicolumn{3}{|c|}{ Solits: Gusion (Gont d) : } & 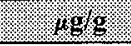 & $.149 / 8$ & $.1 .8 \% 9$ \\
\hline S98T000719 & $224: 7$ & Whole & $<1,930$ & $<2,000$ & $<1,970$ \\
\hline S97T002364 & \multirow[t]{2}{*}{$224: 8$} & Upper half & $<2,020$ & $<2,010$ & $<2,020$ \\
\hline S97T002363 & & Lower half & $<1,850$ & $<1,810$ & $<1,830$ \\
\hline S97T002392 & \multirow[t]{2}{*}{$224: 9$} & Upper half & $<2,190$ & $<2,190$ & $<2,190$ \\
\hline S97T002387 & & Lower half & $<2,230$ & $<2,240$ & $<2,240$ \\
\hline S98T000720 & $224: 10$ & Whole & $<1,960$ & $<1,950$ & $<1,960$ \\
\hline S97T002402 & \multirow[t]{2}{*}{$224: 11$} & Upper half & $<2,010$ & $<2,010$ & $<2,010$ \\
\hline S97T002397 & & Lower half & $<1,970$ & $<1,920$ & $<1,950$ \\
\hline \multicolumn{3}{|l|}{ Wautus: } & 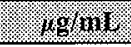 & ogsan: & 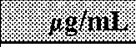 \\
\hline S97T002179 & $223: 1$ & Drainable liquid & $<60.1$ & $<60.1$ & $<60.1$ \\
\hline S97T002188 & $223: 2$ & Drainable liquid & $<60.1$ & $<60.1$ & $<60.1$ \\
\hline S97T002199 & $223: 3$ & Drainable liquid & $<60.1$ & $<60.1$ & $<60.1$ \\
\hline S97T002200 & $223: 4$ & Drainable liquid & $<60.1$ & $<60.1$ & $<60.1$ \\
\hline S97T002215 & $223: 5$ & Drainable liquid & $<60.1$ & $<60.1$ & $<60.1$ \\
\hline S97T002323 & $224: 1$ & Drainable liquid & $<60.1$ & $<60.1$ & $<60.1$ \\
\hline S97T002371 & $224: 3$ & Drainable liquid & $<60.1$ & $<60.1$ & $<60.1$ \\
\hline S97T002372 & $224: 5$ & Drainable liquid & $<60.1$ & $<60.1$ & $<60.1$ \\
\hline
\end{tabular}


Table B2-25. Tank 241-SX-106 Analytical Results: Lithium (ICP). (2 sheets)

\begin{tabular}{|c|c|c|c|c|c|}
\hline $\begin{array}{l}\text { Sample } \\
\text { Number }\end{array}$ & $\begin{array}{l}\text { Sample } \\
\text { Locarton }\end{array}$ & $\begin{array}{l}\text { Sample } \\
\text { Pontion }\end{array}$ & feresulf & Irupicate & Meru \\
\hline \multicolumn{2}{|c|}{ Solids: acid digest } & 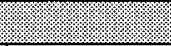 & 1.98 & (2) & 4.98 \\
\hline S98T000695 & $223: 6$ & Whole & $<4.01$ & $<3.76$ & $<3.88$ \\
\hline \$98T000705 & $223: 6 \mathrm{~A}$ & Whole & 41.9 & $<3.93$ & $<22.9^{\mathrm{QC}: \mathrm{e}}$ \\
\hline S98T000706 & $223: 9$ & Whole & $<3.8$ & $<3.76$ & $<3.78$ \\
\hline \$98T000721 & $224: 2$ & Whole & $<2.42$ & $<1.75$ & $<2.08$ \\
\hline S98T000722 & $224: 4$ & Whole & $<1.94$ & $<1.92$ & $<1.93$ \\
\hline S98T000723 & $224: 7$ & Whole & $<3.93$ & $<3.88$ & $<3.91$ \\
\hline S98T000724 & $224: 10$ & Whole & 5.33 & 5.31 & 5.32 \\
\hline \multicolumn{3}{|c|}{ Solids: fusion : } & 189.9 & $10.8 \mathrm{~g}$ & 3.198 \\
\hline S97T002177 & $223: 1$ & Lower half & $<208$ & $<204$ & $<206$ \\
\hline S97T002185 & $223: 2$ & Lower half & $<192$ & $<189$ & $<191$ \\
\hline S97T002194 & $223: 3$ & Lower half & $<188$ & $<187$ & $<188$ \\
\hline S97T002204 & $223: 4$ & Lower half & $<220$ & $<215$ & $<218$ \\
\hline S97T002231 & $223: 5$ & Lower half & $<184$ & $<190$ & $<187$ \\
\hline S98T000694 & $223: 6$ & Whole & $<193$ & $<189$ & $<191$ \\
\hline S98T000703 & $223: 6 \mathrm{~A}$ & Whole & $<185$ & $<189$ & $<187$ \\
\hline S97T002233 & \multirow[t]{2}{*}{$223: 7$} & Upper half & $<210$ & $<200$ & $<205$ \\
\hline \$97T002232 & & Lower half & $<196$ & $<203$ & $<200$ \\
\hline S97T002235 & \multirow[t]{2}{*}{$223: 8$} & Upper half & $<203$ & $<202$ & $<203$ \\
\hline S97T002234 & & Lower half & $<198$ & $<201$ & $<200$ \\
\hline S98T000704 & $223: 9$ & Whole & $<202$ & $<204$ & $<203$ \\
\hline S97T002265 & \multirow[t]{2}{*}{$223: 10$} & Upper half & $<197$ & $<197$ & $<197$ \\
\hline S97T002263 & & Lower half & $<205$ & $<205$ & $<205$ \\
\hline S97T002320 & $224: 1$ & Lower half & $<190$ & $<185$ & $<188$ \\
\hline S98T000717 & $224: 2$ & Whole & $<202$ & $<195$ & $<199$ \\
\hline S97T002334 & $224: 3$ & Lower half & $<183$ & $<185$ & $<184$ \\
\hline S98T000718 & $224: 4$ & Whole & $<201$ & $<199$ & $<200$ \\
\hline S97T002360 & \multirow[t]{2}{*}{$224: 5$} & Upper half & $<200$ & $<204$ & $<202$ \\
\hline S97T002359 & & Lower half & $<202$ & $<200$ & $<201$ \\
\hline S97T002362 & \multirow[t]{2}{*}{$224: 6$} & Upper half & $<182$ & $<175$ & $<179$ \\
\hline \$97T002361 & & Lower half & $<193$ & $<196$ & $<195$ \\
\hline
\end{tabular}


Table B2-25. Tank 241-SX-106 Analytical Results: Lithium (ICP). (2 sheets)

\begin{tabular}{|c|c|c|c|c|c|}
\hline Sample & Sample & Sarrule & iresint & Buplicare & Then \\
\hline \multicolumn{3}{|c|}{ Solids: Gusion ( ( oni d) } & $1.9 / 9.9$ & .1918 & 1098 \\
\hline S98T000719 & $224: 7$ & Whole & $<193$ & $<200$ & $<197$ \\
\hline S97T002364 & \multirow[t]{2}{*}{$224: 8$} & Upper half & $<202$ & $<201$ & $<202$ \\
\hline S97T002363 & & Lower half & $<185$ & $<181$ & $<183$ \\
\hline S97T002392 & \multirow[t]{2}{*}{$224: 9$} & Upper half & $<219$ & $<219$ & $<219$ \\
\hline S97T002387 & & Lower half & $<223$ & $<224$ & $<224$ \\
\hline S98T000720 & $224: 10$ & Whole & $<196$ & $<195$ & $<196$ \\
\hline S97T002402 & \multirow[t]{2}{*}{$224: 11$} & Upper half & $<201$ & $<201$ & $<201$ \\
\hline S97T002397 & & Lower half & $<197$ & $<192$ & $<195$ \\
\hline \multicolumn{2}{|l|}{ Wiguids } & & 9.961 & 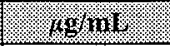 & 19.9 .101 \\
\hline S97T002179 & $223: 1$ & Drainable liquid & $<6.01$ & $<6.01$ & $<6.01$ \\
\hline S97T002188 & $223: 2$ & Drainable liquid & $<6.01$ & $<6.01$ & $<6.01$ \\
\hline S97T002199 & $223: 3$ & Drainable liquid & $<6.01$ & $<6.01$ & $<6.01$ \\
\hline S97T002200 & $223: 4$ & Drainable liquid & 10.6 & 9.74 & 10.2 \\
\hline S97T002215 & $223: 5$ & Drainable liquid & $<6.01$ & $<6.01$ & $<6.01$ \\
\hline S97T002323 & $224: 1$ & Drainable liquid & 9.7 & 9.26 & 9.48 \\
\hline S97T002371 & $224: 3$ & Drainable liquid & 7.56 & 8.06 & 7.81 \\
\hline S97T002372 & $224: 5$ & Drainable liquid & 11.1 & 11.1 & 11.1 \\
\hline
\end{tabular}


Table B2-26. Tank 241-SX-106 Analytical Results: Magnesium (ICP). (2 sheets)

\begin{tabular}{|c|c|c|c|c|c|}
\hline $\begin{array}{l}\text { Scruple } \\
\text { Nimber }\end{array}$ & $\begin{array}{l}\text { Saruple } \\
\text { Socation }\end{array}$ & $\begin{array}{l}\text { Sample } \\
\text { Porton }\end{array}$ & Resuly & Bulleate & nequ \\
\hline \multicolumn{2}{|c|}{ Solids: acid digest " } & $4: 3$. & 1.498 & $1.18 \% 9$ & 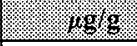 \\
\hline S98T000695 & $223: 6$ & Whole & $<40.1$ & $<37.6$ & $<38.9$ \\
\hline S98T000705 & $223: 6 \mathrm{~A}$ & Whole & $<37.5$ & $<39.3$ & $<38.4$ \\
\hline S98T000706 & $223: 9$ & Whole & $<38$ & $<37.6$ & $<37.8$ \\
\hline S98T000721 & $224: 2$ & Whole & $<24.2$ & $<17.5$ & $<20.9$ \\
\hline S98T000722 & $224: 4$ & Whole & $<19.4$ & $<19.2$ & $<19.3$ \\
\hline S98T000723 & $224: 7$ & Whole & $<39.3$ & $<38.8$ & $<39$ \\
\hline S98T000724 & $224: 10$ & Whole & $<36$ & $<35.3$ & $<35.6$ \\
\hline \multicolumn{2}{|c|}{ Solids: fusion: } & (3. & 1.898 & $1.0 \mathrm{~g} / \mathrm{g}$ & 18. 18 \\
\hline S97T002177 & 223:1 & Lower half & $<2,080$ & $<2,040$ & $<2,060$ \\
\hline S97T002185 & $223: 2$ & Lower half & $<1,920$ & $<1,890$ & $<1,910$ \\
\hline S97T002194 & $223: 3$ & Lower half & $<1,880$ & $<1,870$ & $<1,880$ \\
\hline S97T002204 & $223: 4$ & Lower half & $<2,200$ & $<2,150$ & $<2,180$ \\
\hline S97T002231 & $223: 5$ & Lower half & $<1,840$ & $<1,900$ & $<1,870$ \\
\hline S98T000694 & $223: 6$ & Whole & $<1,930$ & $<1,890$ & $<1,910$ \\
\hline S98T000703 & $223: 6 \mathrm{~A}$ & Whole & $<1,850$ & $<1,890$ & $<1,870$ \\
\hline S97T002233 & \multirow[t]{2}{*}{$223: 7$} & Upper half & $<2,100$ & $<2,000$ & $<2,050$ \\
\hline S97T002232 & & Lower half & $<1,960$ & $<2,030$ & $<2,000$ \\
\hline S97T002235 & \multirow[t]{2}{*}{$223: 8$} & Upper half & $<2,030$ & $<2,020$ & $<2,030$ \\
\hline S97T002234 & & Lower half & $<1,980$ & $<2,010$ & $<2,000$ \\
\hline S98T000704 & $223: 9$ & Whole & $<2,020$ & $<2,040$ & $<2,030$ \\
\hline S97T002265 & \multirow[t]{2}{*}{$223: 10$} & Upper half & $<1,970$ & $<1,970$ & $<1,970$ \\
\hline S97T002263 & & Lower half & $<2,050$ & $<2,050$ & $<2,050$ \\
\hline S97T002320 & $224: 1$ & Lower half & $<1,900$ & $<1,850$ & $<1,880$ \\
\hline S98T000717 & $224: 2$ & Whole & $<2,020$ & $<1,950$ & $<1,990$ \\
\hline S97T002334 & $224: 3$ & Lower half & $<1,830$ & $<1,850$ & $<1,840$ \\
\hline S98T000718 & $224: 4$ & Whole & $<2,010$ & $<1,990$ & $<2,000$ \\
\hline S97T002360 & \multirow[t]{2}{*}{$224: 5$} & Upper half & $<2,000$ & $<2,040$ & $<2,020$ \\
\hline S97T002359 & & Lower half & $<2,020$ & $<2,000$ & $<2,010$ \\
\hline S97T002362 & \multirow[t]{2}{*}{$224: 6$} & Upper half & $<1,820$ & $<1,750$ & $<1,790$ \\
\hline S97T002361 & & Lower half & $<1,930$ & $<1,960$ & $<1,950$ \\
\hline
\end{tabular}


Table B2-26. Tank 241-SX-106 Analytical Results: Magnesium (ICP). (2 sheets)

\begin{tabular}{|c|c|c|c|c|c|}
\hline Sample & Soratron & Fando & Resultit & Hinglueate & rean \\
\hline \multicolumn{2}{|c|}{ 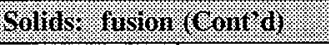 } & (1). & 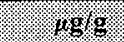 & 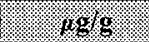 & mg \\
\hline S98T000719 & $224: 7$ & Whole & $<1,930$ & $<2,000$ & $<1,970$ \\
\hline S97T002364 & \multirow[t]{2}{*}{$224: 8$} & Upper half & $<2,020$ & $<2,010$ & $<2,020$ \\
\hline \$97T002363 & & Lower half & $<1,850$ & $<1,810$ & $<1,830$ \\
\hline \$97T002392 & \multirow[t]{2}{*}{$224: 9$} & Upper half & $<2,190$ & $<2,190$ & $<2,190$ \\
\hline S97T002387 & & Lower half & $<2,230$ & $<2,240$ & $<2,240$ \\
\hline S98T000720 & $224: 10$ & Whole & $<1,960$ & $<1,950$ & $<1,960$ \\
\hline S97T002402 & \multirow[t]{2}{*}{$224: 11$} & Upper half & $<2,010$ & $<2,010$ & $<2,010$ \\
\hline S97T002397 & & Lower half & $<1,970$ & $<1,920$ & $<1,950$ \\
\hline \multicolumn{3}{|c|}{ 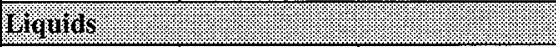 } & \% & (x) 411 & (16\%) \\
\hline S97T002179 & $223: 1$ & Drainable liquid & $<60.1$ & $<60.1$ & $<60.1$ \\
\hline S97T002188 & $223: 2$ & Drainable liquid & $<60.1$ & $<60.1$ & $<60.1$ \\
\hline S97T002199 & $223: 3$ & Drainable liquid & $<60.1$ & $<60.1$ & $<60.1$ \\
\hline \$97T002200 & $223: 4$ & Drainable liquid & $<60.1$ & $<60.1$ & $<60.1$ \\
\hline S97T002215 & $223: 5$ & Drainable liquid & $<60.1$ & $<60.1$ & $<60.1$ \\
\hline \$97T002323 & $224: 1$ & Drainable liquid & $<60.1$ & $<60.1$ & $<60.1$ \\
\hline \$97T002371 & $224: 3$ & Drainable liquid & $<60.1$ & $<60.1$ & $<60.1$ \\
\hline S97T002372 & $224: 5$ & Drainable liquid & $<60.1$ & $<60.1$ & $<60.1$ \\
\hline
\end{tabular}


Table B2-27. Tank 241-SX-106 Analytical Results: Manganese (ICP). (2 sheets)

\begin{tabular}{|c|c|c|c|c|c|}
\hline Samile & \%)14010 & 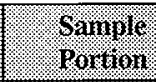 & Rrsingll & Buplicate & 1984 \\
\hline \multicolumn{3}{|c|}{ 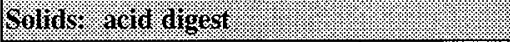 } & . 1969 & 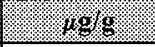 & 109 \\
\hline \$98T000695 & $223: 6$ & Whole & 110 & 111 & 111 \\
\hline S98T000705 & $223: 6 \mathrm{~A}$ & Whole & 161 & 128 & $145^{\mathrm{QC:c}}$ \\
\hline \$98T000706 & $223: 9$ & Whole & 128 & 123 & 126 \\
\hline S98T000721 & $224: 2$ & Whole & $<2.42$ & $<1.75$ & $<2.08$ \\
\hline S98T000722 & $224: 4$ & Whole & $<1.94$ & $<1.92$ & $<1.93$ \\
\hline S98T000723 & $224: 7$ & Whole & 67 & 73.9 & 70.5 \\
\hline S98T000724 & $224: 10$ & Whole & 211 & $200=$ & 206 \\
\hline \multicolumn{3}{|c|}{ Solviv. fusion } & . $14 \mathrm{grg}$ & (2) & 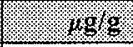 \\
\hline S97T002177 & $223: 1$ & Lower half & $<208$ & $<204$ & $<206$ \\
\hline S97T002185 & $223: 2$ & Lower half & $<192$ & $<189$ & $<191$ \\
\hline$\$ 97 T 002194$ & $223: 3$ & Lower half & $<188$ & $<187$ & $<188$ \\
\hline S97T002204 & $223: 4$ & Lower half & $<220$ & $<215$ & $<218$ \\
\hline \$97T002231 & $223: 5$ & Lower half & $<184$ & $<190$ & $<187$ \\
\hline S98T000694 & $223: 6$ & Whole & $<193$ & $<189$ & $<191$ \\
\hline S98T000703 & $223: 6 \mathrm{~A}$ & Whole & $<185$ & $<189$ & $<187$ \\
\hline \$97T002233 & \multirow[t]{2}{*}{$223: 7$} & Upper half & 416 & 401 & 409 \\
\hline S97T002232 & & Lower half & 324 & 345 & 335 \\
\hline \$97T002235 & \multirow[t]{2}{*}{$223: 8$} & Upper half & $<203$ & $<202$ & $<203$ \\
\hline S97T002234 & & Lower half & $<198$ & $<201$ & $<200$ \\
\hline S98T000704 & $223: 9$ & Whole & $<202$ & $<204$ & $<203$ \\
\hline S97T002265 & \multirow[t]{2}{*}{$223: 10$} & Upper half & 237 & 270 & 254 \\
\hline S97T002263 & & Lower half & 433 & 426 & 430 \\
\hline S97T002320 & $224: 1$ & Lower half & $<190$ & $<185$ & $<188$ \\
\hline \$98T000717 & $224: 2$ & Whole & $<202$ & $<195$ & $<199$ \\
\hline \$97T002334 & $224: 3$ & Lower half & $<183$ & $<185$ & $<184$ \\
\hline \$98T000718 & $224: 4$ & Whole & $<201$ & $<199$ & $<200$ \\
\hline \$97T002360 & \multirow[t]{2}{*}{$224: 5$} & Upper half & $<200$ & $<204$ & $<202$ \\
\hline S97T002359 & & Lower half & 244 & 268 & 256 \\
\hline \$97T002362 & \multirow[t]{2}{*}{$224: 6$} & Upper half & 283 & 305 & 294 \\
\hline S97T002361 & & Lower half & 291 & 312 & 302 \\
\hline
\end{tabular}


Table B2-27. Tank 241-SX-106 Analytical Results: Manganese (ICP). (2 sheets)

\begin{tabular}{|c|c|c|c|c|c|}
\hline $\begin{array}{l}\text { Samile } \\
\text { Number }\end{array}$ & Simple & Sample & Resulle & rinumate. & 110an \\
\hline \multicolumn{3}{|c|}{ 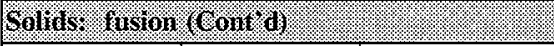 } & 180. & $1.9 \mathrm{gg}$ & (1.0.0. \\
\hline S98T000719 & $224: 7$ & Whole & $<193$ & $<200$ & $<197$ \\
\hline S97T002364 & \multirow[t]{2}{*}{$224: 8$} & Upper half & 363 & 459 & $411^{\mathrm{QC}: \mathrm{e}}$ \\
\hline S97T002363 & & Lower half & 348 & 308 & 328 \\
\hline S97T002392 & \multirow[t]{2}{*}{$224: 9$} & Upper half & 258 & 247 & 253 \\
\hline S97T002387 & & Lower half & 608 & 590 & 599 \\
\hline S98T000720 & $224: 10$ & Whole & 301 & 246 & $274^{\mathrm{QC:e}}$ \\
\hline S97T002402 & \multirow[t]{2}{*}{$224: 11$} & Upper half & 654 & 673 & 664 \\
\hline S97T002397 & & Lower half & 1970 & 2080 & 2030 \\
\hline \multicolumn{3}{|l|}{ Equart: : } & S. & I. 49.10 & (3. $19 / \mathrm{ml}$ \\
\hline S97T002179 & 223:1 & Drainable liquid & $<6.01$ & $<6.01$ & $<6.01$ \\
\hline S97T002188 & $223: 2$ & Drainable liquid & $<6.01$ & $<6.01$ & $<6.01$ \\
\hline S97T002199 & $223: 3$ & Drainable liquid & $<6.01$ & $<6.01$ & $<6.01$ \\
\hline S97T002200 & $223: 4$ & Drainable liquid & $<6.01$ & $<6.01$ & $<6.01$ \\
\hline S97T002215 & $223: 5$ & Drainable liquid & $<6.01$ & $<6.01$ & $<6.01$ \\
\hline S97T002323 & $224: 1$ & Drainable liquid & $<6.01$ & $<6.01$ & $<6.01$ \\
\hline S97T002371 & $224: 3$ & Drainable liquid & $<6.01$ & $<6.01$ & $<6.01$ \\
\hline S97T002372 & $224: 5$ & Drainable liquid & $<6.01$ & $<6.01$ & $<6.01$ \\
\hline
\end{tabular}


Table B2-28. Tank 241-SX-106 Analytical Results: Molybdenum (ICP). (2 sheets)

\begin{tabular}{|c|c|c|c|c|c|}
\hline Samplo & Sample & Parnole & Resuil. & Binglurate & Mearix \\
\hline \multicolumn{3}{|c|}{ Sulist acil dugest } & wase & 1896 & 4.1696 \\
\hline S98T000695 & $223: 6$ & Whole & 40.8 & 41.1 & 41 \\
\hline S98T000705 & $223: 6 \mathrm{~A}$ & Whole & 38.9 & 28.4 & $33.6^{\mathrm{QC}: \mathrm{e}}$ \\
\hline S98T000706 & $223: 9$ & Whole & 27.7 & 27.6 & 27.6 \\
\hline S98T000721 & $224: 2$ & Whole & 39.6 & 40.7 & 40.2 \\
\hline S98T000722 & $224: 4$ & Whole & 41.3 & 42 & 41.6 \\
\hline \$98T000723 & $224: 7$ & Whole & 33.4 & 34 & 33.7 \\
\hline S98T000724 & $224: 10$ & Whole & 34.7 & 34.9 & 34.8 \\
\hline \multicolumn{2}{|c|}{ 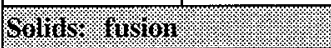 } & 2. & $.120 / 9$ & 18.69 & 1,1989 \\
\hline S97T002177 & $223: 1$ & Lower half & $<1,040$ & $<1,020$ & $<1,030$ \\
\hline S97T002185 & $223: 2$ & Lower half & $<958$ & $<946$ & $<952$ \\
\hline \$97T002194 & $223: 3$ & Lower half & $<939$ & $<934$ & $<937$ \\
\hline S97T002204 & $223: 4$ & Lower half & $<1,100$ & $<1,070$ & $<1,090$ \\
\hline S97T002231 & $223: 5$ & Lower half & $<922$ & $<951$ & $<937$ \\
\hline \$98T000694 & $223: 6$ & Whole & $<965$ & $<946$ & $<956$ \\
\hline S98T000703 & $223: 6 \mathrm{~A}$ & Whole & $<926$ & $<943$ & $<935$ \\
\hline S97T002233 & \multirow[t]{2}{*}{$223: 7$} & Upper half & $<1,050$ & $<1,000$ & $<1,030$ \\
\hline S97T002232 & & Lower half & $<979$ & $<1,010$ & $<995$ \\
\hline \$97T002235 & \multirow[t]{2}{*}{$223: 8$} & Upper half & $<1,010$ & $<1,010$ & $<1,010$ \\
\hline S97T002234 & & Lower half & $<992$ & $<1,000$ & $<996$ \\
\hline S98T000704 & $223: 9$ & Whole & $<1,010$ & $<1,020$ & $<1,020$ \\
\hline \$97T002265 & \multirow[t]{2}{*}{$223: 10$} & Upper half & $<985$ & $<984$ & $<985$ \\
\hline S97T002263 & & Lower half & $<1,020$ & $<1,030$ & $<1,030$ \\
\hline S97T002320 & $224: 1$ & Lower half & $<950$ & $<923$ & $<937$ \\
\hline$\$ 98 T 000717$ & $224: 2$ & Whole & $<1,010$ & $<976$ & $<993$ \\
\hline \$97T002334 & $224: 3$ & Lower half & $<914$ & $<923$ & $<919$ \\
\hline \$98T000718 & $224: 4$ & Whole & $<1,010$ & $<995$ & $<1,000$ \\
\hline S97T002360 & \multirow[t]{2}{*}{$224: 5$} & Upper half & $<999$ & $<1,020$ & $<1,010$ \\
\hline \$97T002359 & & Lower half & $<1,010$ & $<999$ & $<1,000$ \\
\hline S97T002362 & \multirow[t]{2}{*}{$224: 6$} & Upper half & $<910$ & $<873$ & $<892$ \\
\hline S97T002361 & & Lower half & $<967$ & $<978$ & $<973$ \\
\hline
\end{tabular}


HNF-SD-WM-ER-645 Rev. 1

Table B2-28. Tank 241-SX-106 Analytical Results: Molybdenum (ICP). (2 sheets)

\begin{tabular}{|c|c|c|c|c|c|}
\hline $\begin{array}{l}\text { Sample } \\
\text { Number }\end{array}$ & $\begin{array}{l}\text { Sample } \\
\text { Locarion }\end{array}$ & $\begin{array}{l}\text { Sample } \\
\text { Portion }\end{array}$ & result & Buplicate & Mean \\
\hline \multicolumn{3}{|c|}{ 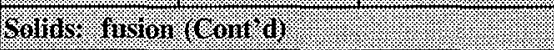 } & 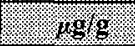 & $14 \mathrm{~g} \mathrm{~g}$. & 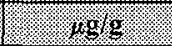 \\
\hline S98T000719 & $224: 7$ & Whole & $<967$ & $<999$ & $<983$ \\
\hline S97T002364 & \multirow[t]{2}{*}{$224: 8$} & Upper half & $<1,010$ & $<1,000$ & $<1,010$ \\
\hline S97T002363 & & Lower half & $<923$ & $<905$ & $<914$ \\
\hline \$97T002392 & \multirow[t]{2}{*}{$224: 9$} & Upper half & $<1,090$ & $<1,100$ & $<1,100$ \\
\hline S97T002387 & & Lower half & $<1,120$ & $<1,120$ & $<1,120$ \\
\hline S98T000720 & $224: 10$ & Whole & $<982$ & $<976$ & $<979$ \\
\hline S97T002402 & \multirow[t]{2}{*}{$224: 11$} & Upper half & $<1,010$ & $<1,000$ & $<1,010$ \\
\hline S97T002397 & & Lower half & $<984$ & $<962$ & $<973$ \\
\hline Hingus & (3.). & (I) & $18 \mathrm{~g} / 111$ & $(109,111$ & $8.18,1110$ \\
\hline S97T002179 & 223:1 & Drainable liquid & 125 & 121. & 123 \\
\hline \$97T002188 & $223: 2$ & Drainable liquid & 126 & 117 & 122 \\
\hline S97T002199 & $223: 3$ & Drainable liquid & 131 & 130 & 131 \\
\hline S97T002200 & $223: 4$ & Drainable liquid & 132 & 128 & 130 \\
\hline S97T002215 & $223: 5$ & Drainable liquid & 132 & 130 & 131 \\
\hline \$97T002323 & $224: 1$ & Drainable liquid & 130 & 132 & 131 \\
\hline S97T002371 & $224: 3$ & Drainable liquid & 127 & 128 & 128 \\
\hline S97T002372 & $224: 5$ & Drainable liquid & 119 & 120 & 120 \\
\hline
\end{tabular}


Table B2-29. Tank 241-SX-106 Analytical Results: Neodymium (ICP). (2 sheets)

\begin{tabular}{|c|c|c|c|c|c|}
\hline Samule & sample & 6ramur & Resulu & Soplicate & 3.1\%an \\
\hline \multicolumn{3}{|c|}{601 ins acid agest } & 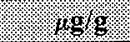 & 1098 & $160 \%$ \\
\hline$\$ 98 T 000695$ & $223: 6$ & Whole & $<40.1$ & $<37.6$ & $<38.9$ \\
\hline S98T000705 & $223: 6 \mathrm{~A}$ & Whole & $<37.5$ & $<39.3$ & $<38.4$ \\
\hline S98T000706 & $223: 9$ & Whole & $<38$ & $<37.6$ & $<37.8$ \\
\hline \$98T000721 & $224: 2$ & Whole & $<24.2$ & $<17.5$ & $<20.9$ \\
\hline S98T000722 & $224: 4$ & Whole & $<19.4$ & $<19.2$ & $<19.3$ \\
\hline \$98T000723 & $224: 7$ & Whole & $<39.3$ & $<38.8$ & $<39$ \\
\hline S98T000724 & $224: 10$ & Whole & $<36$ & $<35.3$ & $<35.6$ \\
\hline \multicolumn{3}{|c|}{ Solids. fisvon. } & 16g & 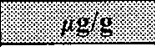 & 169 \\
\hline S97T002177 & $223: 1$ & Lower half & $<2,080$ & $<2,040$ & $<2,060$ \\
\hline S97T002185 & $223: 2$ & Lower half & $<1,920$ & $<1,890$ & $<1,910$ \\
\hline S97T002194 & $223: 3$ & Lower half & $<1,880$ & $<1,870$ & $<1,880$ \\
\hline S97T002204 & $223: 4$ & Lower half & $<2,200$ & $<2,150$ & $<2,180$ \\
\hline S97T002231 & $223: 5$ & Lower half & $<1,840$ & $<1,900$ & $<1,870$ \\
\hline \$98T000694 & $223: 6$ & Whole & $<1,930$ & $<1,890$ & $<1,910$ \\
\hline$\$ 98 \mathrm{~T} 000703$ & $223: 6 \mathrm{~A}$ & Whole & $<1,850$ & $<1,890$ & $<1,870$ \\
\hline S97T002233 & \multirow[t]{2}{*}{$223: 7$} & Upper half & $<2,100$ & $<2,000$ & $<2,050$ \\
\hline \$97T002232 & & Lower half & $<1,960$ & $<2,030$ & $<2,000$ \\
\hline \$97T002235 & \multirow[t]{2}{*}{$223: 8$} & Upper half & $<2,030$ & $<2,020$ & $<2,030$ \\
\hline \$97T002234 & & Lower half & $<1,980$ & $<2,010$ & $<2,000$ \\
\hline S98T000704 & $223: 9$ & Whole & $<2,020$ & $<2,040$ & $<2,030$ \\
\hline$\$ 97 T 002265$ & \multirow[t]{2}{*}{$223: 10$} & Upper half & $<1,970$ & $<1,970$ & $<1,970$ \\
\hline S97T002263 & & Lower half & $<2,050$ & $<2,050$ & $<2,050$ \\
\hline S97T002320 & $224: 1$ & Lower half & $<1,900$ & $<1,850$ & $<1,880$ \\
\hline S98T000717 & $224: 2$ & Whole & $<2,020$ & $<1,950$ & $<1,990$ \\
\hline \$97T002334 & $224: 3$ & Lower half & $<1,830$ & $<1,850$ & $<1,840$ \\
\hline S98T000718 & $224: 4$ & Whole & $<2,010$ & $<1,990$ & $<2,000$ \\
\hline \$97T002360 & \multirow[t]{2}{*}{$224: 5$} & Upper half & $<2,000$ & $<2,040$ & $<2,020$ \\
\hline \$97T002359 & & Lower half & $<2,020$ & $<2,000$ & $<2,010$ \\
\hline \$97T002362 & \multirow[t]{2}{*}{$224: 6$} & Upper half & $<1,820$ & $<1,750$ & $<1,790$ \\
\hline \$97T002361 & & Lower half & $<1,930$ & $<1,960$ & $<1,950$ \\
\hline
\end{tabular}


Table B2-29. Tank 241-SX-106 Analytical Results: Neodymium (ICP). (2 sheets)

\begin{tabular}{|c|c|c|c|c|c|}
\hline Sample & samplo & Samole & Resulu & 3. & Meran \\
\hline \multicolumn{3}{|c|}{ 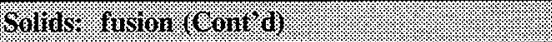 } & . & 1898 & trogs g \\
\hline \$98T000719 & $224: 7$ & Whole & $<1,930$ & $<2,000$ & $<1,970$ \\
\hline S97T002364 & \multirow[t]{2}{*}{$224: 8$} & Upper half & $<2,020$ & $<2,010$ & $<2,020$ \\
\hline \$97T002363 & & Lower half & $<1,850$ & $<1,810$ & $<1,830$ \\
\hline \$97T002392 & \multirow[t]{2}{*}{$224: 9$} & Upper half & $<2,190$ & $<2,190$ & $<2,190$ \\
\hline \$97T002387 & & Lower half & $<2,230$ & $<2,240$ & $<2,240$ \\
\hline \$98T000720 & $224: 10$ & Whole & $<1,960$ & $<1,950$ & $<1,960$ \\
\hline S97T002402 & \multirow[t]{2}{*}{$224: 11$} & Upper half & $<2,010$ & $<2,010$ & $<2,010$ \\
\hline S97T002397 & & Lower half & $<1,970$ & $<1,920$ & $<1,950$ \\
\hline \multicolumn{3}{|l|}{ Liguins } & 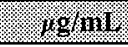 & 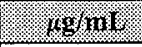 & 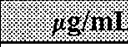 \\
\hline S97T002179 & $223: 1$ & Drainable liquid & $<60.1$ & $<60.1$ & $<60.1$ \\
\hline \$97T002188 & $223: 2$ & Drainable liquid & $<60.1$ & $<60.1$ & $<60.1$ \\
\hline \$97T002199 & $223: 3$ & Drainable liquid & $<60.1$ & $<60.1$ & $<60.1$ \\
\hline \$97T002200 & $223: 4$ & Drainable liquid & $<60.1$ & $<60.1$ & $<60.1$ \\
\hline S97T002215 & $223: 5$ & Drainable liquid & $<60.1$ & $<60.1$ & $<60.1$ \\
\hline S97T002323 & $224: 1$ & Drainable liquid & $<60.1$ & $<60.1$ & $<60.1$ \\
\hline S97T002371 & $224: 3$ & Drainable liquid & $<60.1$ & $<60.1$ & $<60.1$ \\
\hline S97T002372 & $224: 5$ & Drainable liquid & $<60.1$ & $<60.1$ & $<60.1$ \\
\hline
\end{tabular}


Table B2-30. Tank 241-SX-106 Analytical Results: Nickel (ICP).

\begin{tabular}{|c|c|c|c|c|c|}
\hline $\begin{array}{l}\text { Sample } \\
\text { Nunber }\end{array}$ & $\begin{array}{l}\text { Sampilo- } \\
\text { I cocation }\end{array}$ & $\begin{array}{l}\text { Sanjule } \\
\text { Portion. }\end{array}$ & Result & Oupleate & Mean \\
\hline \multicolumn{2}{|c|}{ Solitis acidilingest } & (3: & r & $1.1 .9 .9 \%$ & 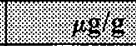 \\
\hline S98T000695 & $223: 6$ & Whole & 24.1 & 25.6 & 24.9 \\
\hline S98T000705 & $223: 6 \mathrm{~A}$ & Whole & 54.4 & 28.8 & $41.6^{\mathrm{eC}: \mathrm{e}}$ \\
\hline S98T000706 & $223: 9$ & Whole & 28.6 & 25.7 & 27.1 \\
\hline S98T000721 & $224: 2$ & Whole & $<4.84$ & $<3.51$ & $<4.17$ \\
\hline S98T000722 & $224: 4$ & Whole & $<3.89$ & $<3.83$ & $<3.86$ \\
\hline S98T000723 & $224: 7$ & Whole & 15.5 & 22.3 & $18.9^{\mathrm{QC}: \mathrm{e}}$ \\
\hline S98T000724 & $224: 10$ & Whole & 19.6 & 19.3 & 19.5 \\
\hline Miguids : & (3) & (3. & $.10 \mathrm{~g} / \mathrm{nu}$ & d $18 \mathrm{gmu}$ & 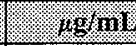 \\
\hline S97T002179 & $223: 1$ & Drainable liquid & $<12$ & $<12$ & $<12$ \\
\hline S97T002188 & $223: 2$ & Drainable liquid & $<12$ & $<12$ & $<12$ \\
\hline S97T002199 & $223: 3$ & Drainable liquid & $<12$ & $<12$ & $<12$ \\
\hline S97T002200 & $223: 4$ & Drainable liquid & $<12$ & $<12$ & $<12$ \\
\hline S97T002215 & $223: 5$ & Drainable liquid & $<12$ & $<12$ & $<12$ \\
\hline S97T002323 & $224: 1$ & Drainable liquid & $<12$ & $<12$ & $<12$ \\
\hline S97T002371 & $224: 3$ & Drainable liquid & $<12$ & $<12$ & $<12$ \\
\hline S97T002372 & $224: 5$ & Drainable liquid & $<12$ & $<12$ & $<12$ \\
\hline
\end{tabular}


Table B2-31. Tank 241-SX-106 Analytical Results: Phosphorus (ICP). (2 sheets)

\begin{tabular}{|c|c|c|c|c|c|}
\hline Samule & $\begin{array}{l}\text { Samiple } \\
\text { Location }\end{array}$ & Sambie & V. & morlicate & Mern \\
\hline \multicolumn{3}{|c|}{ 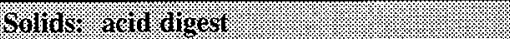 } & 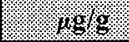 & $1.9 \mathrm{gg}$ & 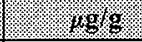 \\
\hline S98T000695 & $223: 6$ & Whole & 1,210 & 1,250 & 1,230 \\
\hline S98T000705 & $223: 6 \mathrm{~A}$ & Whole & 1,220 & 691 & $956^{\mathrm{QC:e}}$ \\
\hline S98T000706 & $223: 9$ & Whole & 696 & 670 & 683 \\
\hline S98T000721 & $224: 2$ & Whole & 722 & 727 & 725 \\
\hline S98T000722 & $224: 4$ & Whole & 704 & 708 & 706 \\
\hline S98T000723 & $224: 7$ & Whole & 1,060 & 1,090 & 1,080 \\
\hline S98T000724 & $224: 10$ & Whole & 742 & 737 & 740 \\
\hline \multicolumn{3}{|c|}{ 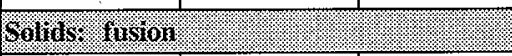 } & (4ag) & 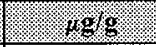 & 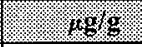 \\
\hline S97T002177 & $223: 1$ & Lower half & $<4,160$ & $<4,070$ & $<4,120$ \\
\hline S97T002185 & $223: 2$ & Lower half & 10,100 & 6,440 & $8,270^{\mathrm{eC}: \mathrm{e}}$ \\
\hline S97T002194 & $223: 3$ & Lower half & 4,080 & $<3,730$ & $<3,910^{\text {QC:d }}$ \\
\hline S97T002204 & $223: 4$ & Lower half & 11,400 & 5,450 & $8,430^{\mathrm{QC}: \mathrm{d}, c}$ \\
\hline S97T002231 & $223: 5$ & Lower half & $<3,690$ & $<3,800$ & $<3,750^{\text {QC:d }}$ \\
\hline S98T000694 & $223: 6$ & Whole & $<3,860$ & $<3,780$ & $<3,820$ \\
\hline S98T000703 & $223: 6 \mathrm{~A}$ & Whole & $<3,700$ & $<3,770$ & $<3,740$ \\
\hline S97T002233 & \multirow[t]{2}{*}{$223: 7$} & Upper half & $<4,200$ & 4,850 & $<4,530$ \\
\hline S97T002232 & & Lower half & $<3,920$ & $<4,060$ & $<3,990$ \\
\hline \$97T002235 & \multirow[t]{2}{*}{$223: 8$} & Upper half & $<4,050$ & $<4,040$ & $<4,050$ \\
\hline S97T002234 & & Lower half & $<3,970$ & $<4,010$ & $<3,990$ \\
\hline S98T000704 & $223: 9$ & Whole & $<4,040$ & $<4,080$ & $<4,060$ \\
\hline S97T002265 & \multirow[t]{2}{*}{$223: 10$} & Upper half & $<3,940$ & $<3,930$ & $<3,940$ \\
\hline S97T002263 & & Lower half & $<4,100$ & $<4,100$ & $<4,100$ \\
\hline S97T002320 & $224: 1$ & Lower half & $<3,800$ & $<3,690$ & $<3,750$ \\
\hline S98T000717 & $224: 2$ & Whole & $<4,050$ & $<3,900$ & $<3,980$ \\
\hline \$97T002334 & $224: 3$ & Lower half & $<3,660$ & $<3,690$ & $<3,680$ \\
\hline S98T000718 & $224: 4$ & Whole & $<4,030$ & $<3,980$ & $<4,010$ \\
\hline \$97T002360 & \multirow[t]{2}{*}{$224: 5$} & Upper half & $<4,000$ & $<4,070$ & $<4,040$ \\
\hline S97T002359 & & Lower half & $<4,040$ & $<4,000$ & $<4,020$ \\
\hline S97T002362 & \multirow[t]{2}{*}{$224: 6$} & Upper half & 3,660 & 4,150 & 3,910 \\
\hline S97T002361 & & Lower half & $<3,870$ & $<3,910$ & $<3,890$ \\
\hline
\end{tabular}


Table B2-31. Tank 241-SX-106 Analytical Results: Phosphorus (ICP). (2 sheets)

\begin{tabular}{|c|c|c|c|c|c|}
\hline Samine & gormole & samule & Krsulu & Buplisare & (16) \\
\hline \multicolumn{3}{|c|}{ Solids - fisson (sont $\mathrm{d}$ ) } & 1809 & 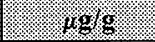 & xys \\
\hline S98T000719 & $224: 7$ & Whole & $<3,870$ & $<4,000$ & $<3,940$ \\
\hline S97T002364 & \multirow[t]{2}{*}{$224: 8$} & Upper half & $<4,040$ & $<4,010$ & $<4,030$ \\
\hline \$97T002363 & & Lower half & $<3,690$ & $<3,620$ & $<3,660$ \\
\hline S97T002392 & \multirow[t]{2}{*}{$224: 9$} & Upper half & $<4,370$ & $<4,380$ & $<4,380$ \\
\hline S97T002387 & & Lower half & 6,100 & 6,030 & 6,070 \\
\hline S98T000720 & $224: 10$ & Whole & $<3,930$ & $<3,900$ & $<3,920$ \\
\hline S97T002402 & \multirow[t]{2}{*}{$224: 11$} & Upper half & 10,700 & 10,500 & 10,600 \\
\hline \$97T002397 & & Lower half & 10,100 & 12,400 & $11,300^{\mathrm{QC}: \mathrm{e}}$ \\
\hline \multicolumn{3}{|c|}{ Liquids } & $\mu \mathrm{g} / \mathbf{m L}$ & $\mu \mathrm{g} / \mathbf{m L}$ & $\mu \mathrm{g} / \mathrm{mL}$ \\
\hline S97T002179 & $223: 1$ & Drainable liquid & 1,140 & 1,110 & 1,130 \\
\hline \$97T002188 & $223: 2$ & Drainable liquid & 1,110 & 1,060 & 1,090 \\
\hline S97T002199 & $223: 3$ & Drainable liquid & 1,040 & 1,040 & $1,040^{\mathrm{eC}: \mathrm{c}}$ \\
\hline \$97T002200 & $223: 4$ & Drainable liquid & 1,170 & 1,130 & 1,150 \\
\hline S97T002215 & $223: 5$ & Drainable liquid & 1,340 & 1,630 & 1,490 \\
\hline S97T002323 & $224: 1$ & Drainable liquid & 1,200 & 1,210 & 1,210 \\
\hline S97T002371 & $224: 3$ & Drainable liquid & 1,040 & 1,060 & 1,050 \\
\hline$\$ 97 T 002372$ & $224: 5$ & Drainable liquid & 1,020 & 1,040 & 1,030 \\
\hline
\end{tabular}


Table B2-32. Tank 241-SX-106 Analytical Results: Potassium (ICP).

\begin{tabular}{|c|c|c|c|c|c|}
\hline $\begin{array}{l}\text { Sample. } \\
\text { Nunber }\end{array}$ & $\begin{array}{l}\text { Sample } \\
\text { tocalion }\end{array}$ & $\begin{array}{l}\text { Sample. } \\
\text { Sorion }\end{array}$ & Resuli: & Buplicate & Mewin: \\
\hline \multicolumn{2}{|c|}{ Solids: acidydigest } & 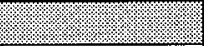 & 1098 & 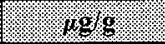 & 11969 \\
\hline S98T000695 & $223: 6$ & Whole & 1,140 & 1,180 & 1,160 \\
\hline S98T000705 & $223: 6 \mathrm{~A}$ & Whole & 1,110 & 880 & $9,95^{\mathrm{QC}: \mathrm{e}}$ \\
\hline S98T000706 & $223: 9$ & Whole & 879 & 807 & 843 \\
\hline S98T000721 & $224: 2$ & Whole & 1,290 & 1,250 & 1,270 \\
\hline S98T000722 & $224: 4$ & Whole & 1,300 & 1,350 & 1,330 \\
\hline S98T000723 & $224: 7$ & Whole & 1,100 & 1,090 & 1,100 \\
\hline S98T000724 & $224: 10$ & Whole & 1,060 & 1,180 & 1,120 \\
\hline Miginds & $1: 2:$ & & 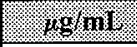 & (18:111: & yglnul \\
\hline S97T002179 & 223:1 & Drainable liquid & 3,850 & 3,670 & 3,760 \\
\hline S97T002188 & $223: 2$ & Drainable liquid & 3,960 & 3,670 & 3,820 \\
\hline S97T002199 & $223: 3$ & Drainable liquid & 4,020 & 3,940 & $3,980^{\mathrm{eC}: \mathrm{c}}$ \\
\hline S97T002200 & $223: 4$ & Drainable liquid & 4,020 & 3,760 & $3,890^{\mathrm{eC}: c}$ \\
\hline S97T002215 & $223: 5$ & Drainable liquid & 4,030 & 3,960 & 4,000 \\
\hline S97.T002323 & $224: 1$ & Drainable liquid & 4,100 & 4,310 & 4,210 \\
\hline S97T002371 & $224: 3$ & Drainable liquid & 3,790 & 3,860 & 3,830 \\
\hline S97T002372 & $224: 5$ & Drainable liquid & 3,660 & 3,660 & 3,660 \\
\hline
\end{tabular}


Table B2-33. Tank 241-SX-106 Analytical Results: Samarium (ICP). (2 sheets)

\begin{tabular}{|c|c|c|c|c|c|}
\hline Sample & Shaphle & \%omplore & Resul & $80131 x_{\mathrm{atc}}$ & Mean \\
\hline \multicolumn{2}{|c|}{ Gollas \% avid ingest } & & 14. & 1096 & 10069 \\
\hline \$98T000695 & $223: 6$ & Whole & $<40.1$ & $<37.6$ & $<38.9$ \\
\hline S98T000705 & $223: 6 \mathrm{~A}$ & Whole & $<37.5$ & $<39.3$ & $<38.4$ \\
\hline S98T000706 & $223: 9$ & Whole & $<38$ & $<37.6$ & $<37.8$ \\
\hline S98T000721 & $224: 2$ & Whole & $<24.2$ & $<17.5$ & $<20.9$ \\
\hline S98T000722 & $224: 4$ & Whole & $<19.4$ & $<19.2$ & $<19.3$ \\
\hline S98T000723 & $224: 7$ & Whole & $<39.3$ & $<38.8$ & $<39$ \\
\hline \$98T000724 & $224: 10$ & Whole & $<36$ & $<35.3$ & $<35.6$ \\
\hline \multicolumn{2}{|c|}{ Solitis / fision } & & 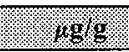 & 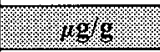 & \% 199 \\
\hline S97T002177 & 223:1 & Lower half & $<2,080$ & $<2,040$ & $<2,060$ \\
\hline S97T002185 & 223: 2 & Lower half & $<1,920$ & $<1,890$ & $<1,910$ \\
\hline \$97T002194 & $223: 3$ & Lower half & $<1,880$ & $<1,870$ & $<1,880$ \\
\hline S97T002204 & 223: 4 & Lower half & $<2,200$ & $<2,150$ & $<2,180$ \\
\hline S97T002231 & 223: 5 & Lower half & $<1,840$ & $<1,900$ & $<1,870$ \\
\hline S98T000694 & $223: 6$ & Whole & $<1,930$ & $<1,890$ & $<1,910$ \\
\hline S98T000703 & 223: $6 \mathrm{~A}$ & Whole & $<1,850$ & $<1,890$ & $<1,870$ \\
\hline \$97T002233 & \multirow[t]{2}{*}{$223: 7$} & Upper half & $<2,100$ & $<2,000$ & $<2,050$ \\
\hline S97T002232 & & Lower half & $<1,960$ & $<2,030$ & $<2,000$ \\
\hline S97T002235 & \multirow[t]{2}{*}{$223: 8$} & Upper half & $<2,030$ & $<2,020$ & $<2,030$ \\
\hline \$97T002234 & & Lower half & $<1,980$ & $<2,010$ & $<2,000$ \\
\hline S98T000704 & $223: 9$ & Whole & $<2,020$ & $<2,040$ & $<2,030$ \\
\hline$\$ 97 T 002265$ & \multirow[t]{2}{*}{$223: 10$} & Upper half & $<1,970$ & $<1,970$ & $<1,970$ \\
\hline S97T002263 & & Lower half & $<2,050$ & $<2,050$ & $<2,050$ \\
\hline \$97T002320 & 224: 1 & Lower half & $<1,900$ & $<1,850$ & $<1,880$ \\
\hline S98T000717 & $224: 2$ & Whole & $<2,020$ & $<1,950$ & $<1,990$ \\
\hline S97T002334 & 224: 3 & Lower half & $<1,830$ & $<1,850$ & $<1,840$ \\
\hline S98T000718 & 224: 4 & Whole & $<2,010$ & $<1,990$ & $<2,000$ \\
\hline S97T002360 & \multirow[t]{2}{*}{$224: 5$} & Upper half & $<2,000$ & $<2,040$ & $<2,020$ \\
\hline S97T002359 & & Lower half & $<2,020$ & $<2,000$ & $<2,010$ \\
\hline S97T002362 & \multirow[t]{2}{*}{$224: 6$} & Upper half & $<1,820$ & $<1,750$ & $<1,790$ \\
\hline S97T002361 & & Lower half & $<1,930$ & $<1,960$ & $<1,950$ \\
\hline
\end{tabular}


HNF-SD-WM-ER-645 Rev. 1

Table B2-33. Tank 241-SX-106 Analytical Results: Samarium (ICP). (2 sheets)

\begin{tabular}{|c|c|c|c|c|c|}
\hline $\begin{array}{l}\text { Samijle } \\
\text { Vumber. }\end{array}$ & Somple & $\begin{array}{l}\text { Samile } \\
\text { Portion }\end{array}$ & Resultit. & Briviliarie & Meara \\
\hline \multicolumn{2}{|c|}{ Sollis: frision (Con'or): } & 2. & 1,89 & 19.8 & (3. \\
\hline S98T000719 & 224: 7 & Whole & $<1,930$ & $<2,000$ & $<1,970$ \\
\hline S97T002364 & \multirow[t]{2}{*}{ 224: 8} & Upper half & $<2,020$ & $<2,010$ & $<2,020$ \\
\hline S97T002363 & & Lower half & $<1,850$ & $<1,810$ & $<1,830$ \\
\hline S97T002392 & \multirow[t]{2}{*}{ 224: 9} & Upper half & $<2,190$ & $<2,190$ & $<2,190$ \\
\hline S97T002387 & & Lower-half & $<2,230$ & $<2,240$ & $<2,240$ \\
\hline S98T000720 & $224: 10$ & Whole & $<1,960$ & $<1,950$ & $<1,960$ \\
\hline S97T002402 & \multirow[t]{2}{*}{$224: 11$} & Upper half & $<2,010$ & $<2,010$ & $<2,010$ \\
\hline S97T002397 & & Lower half & $<1,970$ & $<1,920$ & $<1,950$ \\
\hline \multicolumn{3}{|c|}{ Mquids } & 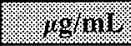 & .99118 & yg/min \\
\hline S97T002179 & 223: 1 & Drainable liquid & $<60.1$ & $<60.1$ & $<60.1$ \\
\hline S97T002188 & $223: 2$ & Drainable liquid & $<60.1$ & $<60.1$ & $<60.1$ \\
\hline S97T002199 & $223: 3$ & Drainable liquid & $<60.1$ & $<60.1$ & $<60.1$ \\
\hline S97T002200 & $223: 4$ & Drainable liquid & $<60.1$ & $<60.1$ & $<60.1$ \\
\hline S97T002215 & $223: 5$ & Drainable liquid & $<60.1$ & $<60.1$ & $<60.1$ \\
\hline S97T002323 & 224: 1 & Drainable liquid & $<60.1$ & $<60.1$ & $<60.1$ \\
\hline S97T002371 & 224: 3 & Drainable liquid & $<60.1$ & $<60.1$ & $<60.1$ \\
\hline S97T002372 & $224: 5$ & Drainable liquid & $<60.1$ & $<60.1$ & $<60.1$ \\
\hline
\end{tabular}


Table B2-34. Tank 241-SX-106 Analytical Results: Selenium (ICP). (2 sheets)

\begin{tabular}{|c|c|c|c|c|c|}
\hline $\begin{array}{l}\text { Samplo } \\
\text { Munber }\end{array}$ & Sample & Sample & Resulu & Buplicare & ainera \\
\hline \multicolumn{2}{|c|}{ 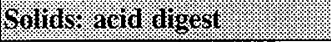 } & (3) & $109 \%$ & 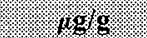 & (xolg \\
\hline \$98T000695 & $223: 6$ & Whole & $<40.1$ & $<37.6$ & $<38.9$ \\
\hline S98T000705 & $223: 6 \mathrm{~A}$ & Whole & $<37.5$ & $<39.3$ & $<38.4$ \\
\hline S98T000706 & 223: 9 & Whole & $<38$ & $<37.6$ & $<37.8$ \\
\hline S98T000721 & 224: 2 & Whole & $<24.2$ & $<17.5$ & $<20.9$ \\
\hline S98T000722 & 224: 4 & Whole & $<19.4$ & $<19.2$ & $<19.3$ \\
\hline S98T000723 & 224: 7 & Whole & $<39.3$ & $<38.8$ & $<39$ \\
\hline S98T000724 & $224: 10$ & Whole & $<36$ & $<35.3$ & $<35.6$ \\
\hline \multicolumn{2}{|l|}{ 6olnas $/$ fusion } & & 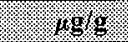 & $148 \%$ & 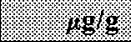 \\
\hline \$97T002177 & $223: 1$ & Lower half & $<2,080$ & $<2,040$ & $<2,060$ \\
\hline S97T002185 & $223: 2$ & Lower half & $<1,920$ & $<1,890$ & $<1,910$ \\
\hline \$97T002194 & $223: 3$ & Lower half & $<1,880$ & $<1,870$ & $<1,880$ \\
\hline S97T002204 & $223: 4$ & Lower half & $<2,200$ & $<2,150$ & $<2,180$ \\
\hline S97T002231 & $223: 5$ & Lower half & $<1,840$ & $<1,900$ & $<1,870$ \\
\hline \$98T000694 & $223: 6$ & Whole & $<1,930$ & $<1,890$ & $<1,910$ \\
\hline \$98T000703 & $223: 6 \mathrm{~A}$ & Whole & $<1,850$ & $<1,890$ & $<1,870$ \\
\hline \$97T002233 & \multirow[t]{2}{*}{$223: 7$} & Upper half & $<2,100$ & $<2,000$ & $<2,050$ \\
\hline S97T002232 & & Lower half & $<1,960$ & $<2,030$ & $<2,000$ \\
\hline S97T002235 & \multirow[t]{2}{*}{$223: 8$} & Upper half & $<2,030$ & $<2,020$ & $<2,030$ \\
\hline S97T002234 & & Lower half & $<1,980$ & $<2,010$ & $<2,000$ \\
\hline \$98T000704 & $223: 9$ & Whole & $<2,020$ & $<2,040$ & $<2,030$ \\
\hline S97T002265 & \multirow[t]{2}{*}{$223: 10$} & Upper half & $<1,970$ & $<1,970$ & $<1,970$ \\
\hline S97T002263 & & Lower half & $<2,050$ & $<2,050$ & $<2 ; 050$ \\
\hline S97T002320 & $224: 1$ & Lower half & $<1,900$ & $<1,850$ & $<1,880$ \\
\hline S98T000717 & $224: 2$ & Whole & $<2,020$ & $<1,950$ & $<1,990$ \\
\hline S97T002334 & $224: 3$ & Lower half & $<1,830$ & $<1,850$ & $<1,840$ \\
\hline S98T000718 & $224: 4$ & Whole & $<2,010$ & $<1,990$ & $<2,000$ \\
\hline S97T002360 & \multirow[t]{2}{*}{$224: 5$} & Upper half & $<2,000$ & $<2,040$ & $<2,020$ \\
\hline \$97T002359 & & Lower half & $<2,020$ & $<2,000$ & $<2,010$ \\
\hline$\$ 97 \mathrm{~T} 002362$ & \multirow[t]{2}{*}{$224: 6$} & Upper half & $<1,820$ & $<1,750$ & $<1,790$ \\
\hline S97T002361 & & Lower half & $<1,930$ & $<1,960$ & $<1,950$ \\
\hline
\end{tabular}


Table B2-34. Tank 241-SX-106 Analytical Results: Selenium (ICP). (2 sheets)

\begin{tabular}{|c|c|c|c|c|c|}
\hline $\begin{array}{l}\text { Sample: } \\
\text { Ninber }\end{array}$ & $\begin{array}{l}\text { Sarivilo } \\
\text { I location }\end{array}$ & : Samples & Resull: & 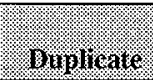 & Mean \\
\hline \multicolumn{2}{|c|}{ Soldos: rusion (Contid). } & 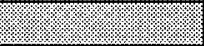 & 1,099 & $.10 \mathrm{~g} / \mathrm{g}$. & 1498 \\
\hline S98T000719 & $224: 7$ & Whole & $<1,930$ & $<2,000$ & $<1,970$ \\
\hline S97T002364 & \multirow[t]{2}{*}{$224: 8$} & Upper half & $<2,020$ & $<2,010$ & $<2,020$ \\
\hline S97T002363 & & Lower half & $<1,850$ & $<1,810$ & $<1,830$ \\
\hline S97T002392 & \multirow[t]{2}{*}{$224: 9$} & Upper half & $<2,190$ & $<2,190$ & $<2,190$ \\
\hline S97T002387 & & Lower half & $<2,230$ & $<2,240$ & $<2,240$ \\
\hline S98T000720 & $224: 10$ & Whole & $<1,960$ & $<1,950$ & $<1,960$ \\
\hline S97T002402 & \multirow[t]{2}{*}{$224: 11$} & Upper half & $<2,010$ & $<2,010$ & $<2,010$ \\
\hline S97T002397 & & Lower half & $<1,970$ & $<1,920$ & $<1,950$ \\
\hline \multicolumn{3}{|l|}{ Wiguids: } & $1.89 \mathrm{mi}$ & gymiri & $=11 \mathrm{~g} / \mathrm{min}$ \\
\hline S97T002179 & $223: 1$ & Drainable liquid & $<60.1$ & $<60.1$ & $<60.1$ \\
\hline S97T002188 & $223: 2$ & Drainable liquid & $<60.1$ & $<60.1$ & $<60.1$ \\
\hline S97T002199 & $223: 3$ & Drainable liquid & $<60.1$ & $<60.1$ & $<60.1$ \\
\hline S97T002200 & $223: 4$ & Drainable liquid & $<60.1$ & $<60.1$ & $<60.1$ \\
\hline S97T002215 & $223: 5$ & Drainable liquid & $<60.1$ & $<60.1$ & $<60.1$ \\
\hline S97T002323 & $224: 1$ & Drainable liquid & $<60.1$ & $<60.1$ & $<60.1$ \\
\hline S97T002371 & $224: 3$ & Drainable liquid & $<60.1$ & $<60.1$ & $<60.1$ \\
\hline S97T002372 & $224: 5$ & Drainable liquid & $<60.1$ & $<60.1$ & $<60.1$ \\
\hline
\end{tabular}


Table B2-35. Tank 241-SX-106 Analytical Results: Silicon (ICP). (2 sheets)

\begin{tabular}{|c|c|c|c|c|c|}
\hline $\begin{array}{l}\text { Sample } \\
\text { Nimber }\end{array}$ & $\begin{array}{l}\text { Samples } \\
\text { Y zocalion }\end{array}$ & $\begin{array}{l}\text { Sample } \\
\text { rontion }\end{array}$ & Tresull & Bivilicare & vian \\
\hline \multicolumn{2}{|c|}{ Solids: acid digest:? } & 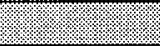 & $1.96 \%$ & 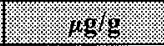 & $10 \mathrm{gs}$ \\
\hline S98T000695 & $223: 6$ & Whole & 218 & 204 & $211^{\mathrm{QC}: \mathrm{b}}$ \\
\hline S98T000705 & $223: 6 \mathrm{~A}$ & Whole & 201 & 289 & $245^{\text {QC:b,e }}$ \\
\hline S98T000706 & $223: 9$ & Whole & 294 & 278 & $286^{\mathrm{QC}: \mathrm{b}}$ \\
\hline S98T000721 & $224: 2$ & Whole & 148 & 132 & $140^{\text {ec:b }}$ \\
\hline S98T000722 & $224: 4$ & Whole & 141 & 96.7 & $119^{\text {QC:b,e }}$ \\
\hline S98T000723 & $224: 7$ & Whole & 177 & 201 & 189 \\
\hline S98T000724 & $224: 10$ & Whole & 213 & 213 & 213 \\
\hline \multicolumn{2}{|c|}{ Solids: fusion } & 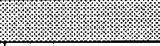 & 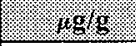 & .1898 & 1.1890 \\
\hline S97T002177 & $223: 1$ & Lower half & $<1,040$ & $<1,020$ & $<1,030$ \\
\hline S97T002185 & $223: 2$ & Lower half & $<958$ & $<946$ & $<952$ \\
\hline S97T002194 & $223: 3$ & Lower half & $<939$ & $<934$ & $<937$ \\
\hline S97T002204 & $223: 4$ & Lower half & $<1,100$ & $<1,070$ & $<1,090$ \\
\hline S97T002231 & $223: 5$ & Lower half & 994 & $<951$ & $<973$ \\
\hline S98T000694 & $223: 6$ & Whole & $<965$ & $<946$ & $<956$ \\
\hline S98T000703 & $223: 6 \mathrm{~A}$ & Whole & $<926$ & $<943$ & $<935$ \\
\hline S97T002233 & \multirow[t]{2}{*}{$223: 7$} & Upper half & 2,250 & 1,750 & $2,000^{\mathrm{ec}: \mathrm{e}}$ \\
\hline S97T002232 & & Lower half & 1,050 & 1,820 & $1,440^{\mathrm{QC}: \mathrm{e}}$ \\
\hline S97T002235 & \multirow[t]{2}{*}{$223: 8$} & Upper half & $<1,010$ & $<1,010$ & $<1,010$ \\
\hline S97T002234 & & Lower half & $<992$ & $<1,000$ & $<996$ \\
\hline S98T000704 & 223:9 & Whole & $<1,010$ & $<1,020$ & $<1,020$ \\
\hline S97T002265 & \multirow[t]{2}{*}{$223: 10$} & Upper half & $<985$ & $<984$ & $<985$ \\
\hline S97T002263 & & Lower half & $<1,020$ & $<1,030$ & $<1,030$ \\
\hline S97T002320 & $224: 1$ & Lower half & $<950$ & $<923$ & $<937$ \\
\hline S98T000717 & $224: 2$ & Whole & $<1,010$ & $<976$ & $<993$ \\
\hline S97T002334 & $224: 3$ & Lower half & $<914$ & $<923$ & $<919$ \\
\hline S98T000718 & $224: 4$ & Whole & $<1,010$ & $<995$ & $<1,000$ \\
\hline S97T002360 & \multirow[t]{2}{*}{$224: 5$} & Upper half & $<999$ & $<1,020$ & $<1,010$ \\
\hline S97T002359 & & Lower half & $<1,010$ & $<999$ & $<1,000$ \\
\hline S97T002362 & \multirow[t]{2}{*}{$224: 6$} & Upper half & $<910$ & $<873$ & $<892$ \\
\hline S97T002361 & & Lower half & $<967$ & $<978$ & $<973$ \\
\hline
\end{tabular}


Table B2-35. Tank 241-SX-106 Analytical Results: Silicon (ICP). (2 sheets)

\begin{tabular}{|c|c|c|c|c|c|}
\hline $\begin{array}{l}\text { Samper } \\
\text { Mamper }\end{array}$ & Sample & sampror & ressill & Singlinatio & $40 \%$ \\
\hline \multicolumn{2}{|c|}{ 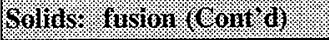 } & (1.:- & 196 & 4.2 .98 & 198 \\
\hline S98T000719 & $224: 7$ & Whole & $<967$ & $<999$ & $<983$ \\
\hline S97T002364 & \multirow[t]{2}{*}{$224: 8$} & Upper half & $<1,010$ & $<1,000$ & $<1,010$ \\
\hline S97T002363 & & Lower half & $<923$ & $<905$ & $<914$ \\
\hline S97T002392 & \multirow[t]{2}{*}{$224: 9$} & Upper half & $<1,090$ & $<1,100$ & $<1,100$ \\
\hline S97T002387 & & Lower half & 1,150 & $<1,120$ & $<1,140$ \\
\hline S98T000720 & $224: 10$ & Whole & $<982$ & $<976$ & $<979$ \\
\hline S97T002402 & \multirow[t]{2}{*}{$224: 11$} & Upper half & $<1,010$ & $<1,000$ & $<1,010$ \\
\hline S97T002397 & & Lower half & $<984$ & 1,000 & $<992$ \\
\hline \multicolumn{2}{|l|}{ Higuids } & 展 & 139411 & 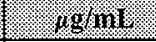 & 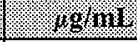 \\
\hline \$97T002179 & $223: 1$ & Drainable liquid & 64.8 & 63.4 & 64.1 \\
\hline \$97T002188 & $223: 2$ & Drainable liquid & 57.3 & 55.6 & 56.5 \\
\hline S97T002199 & $223: 3$ & Drainable liquid & 58.6 & 56.2 & 57.4 \\
\hline S97T002200 & $223: 4$ & Drainable liquid & 74.6 & 66.7 & 70.7 \\
\hline S97T002215 & $223: 5$ & Drainable liquid & 49.2 & 50.4 & 49.8 \\
\hline \$97T002323 & $224: 1$ & Drainable liquid & 181 & 175 & 178 \\
\hline S97T002371 & $224: 3$ & Drainable liquid & 97.9 & 96.3 & 97.1 \\
\hline \$97T002372 & $224: 5$ & Drainable liquid & 68.9 & 67.8 & 68.3 \\
\hline
\end{tabular}


HNF-SD-WM-ER-645 Rev. 1

Table B2-36. Tank 241-SX-106 Analytical Results: Silver (ICP). (2 sheets)

\begin{tabular}{|c|c|c|c|c|c|}
\hline Sample & $\begin{array}{l}\text { Sample: } \\
\text { L Location }\end{array}$ & $\begin{array}{l}\text { Sample } \\
\text { Portion }\end{array}$ & Resuls: & Buplicate. & Mean \\
\hline \multicolumn{2}{|c|}{ Srints ach digest } & (3.:- & 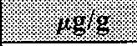 & 1.189 .8 & 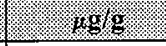 \\
\hline S98T000695 & $223: 6$ & Whole & 8.11 & 8.57 & 8.34 \\
\hline S98T000705 & $223: 6 \mathrm{~A}$ & Whole & 8.26 & 7.91 & 8.09 \\
\hline S98T000706 & $223: 9$ & Whole & 8.4 & 8.2 & 8.3 \\
\hline S98T000721 & $224: 2$ & Whole & 6.31 & 6.36 & 6.34 \\
\hline S98T000722 & $224: 4$ & Whole & 7.29 & 7.07 & 7.18 \\
\hline S98T000723 & $224: 7$ & Whole & 7.97 & 8.35 & 8.16 \\
\hline S98T000724 & $224: 10$ & Whole & 10.2 & 10.5 & 10.3 \\
\hline \multicolumn{2}{|c|}{ Solrus: fusion } & 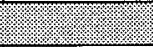 & 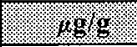 & $1.9 \mathrm{~g}$ & $17.70 \mathrm{~g} g$ \\
\hline S97T002177 & $223: 1$ & Lower half & $<208$ & $<204$ & $<206$ \\
\hline S97T002185 & $223: 2$ & Lower half & $<192$ & $<189$ & $<191$ \\
\hline S97T002194 & $223: 3$ & Lower half & $<188$ & $<187$ & $<188^{\mathrm{eC}: \mathrm{c}}$ \\
\hline S97T002204 & $223: 4$ & Lower half & $<220$ & $<215$ & $<218^{\mathrm{QC}: \mathrm{c}}$ \\
\hline S97T002231 & $223: 5$ & Lower half & $<184$ & $<190$ & $<187^{\mathrm{QC}: \mathrm{c}}$ \\
\hline S98T000694 & $223: 6$ & Whole & $<193$ & $<189$ & $<191$ \\
\hline S98T000703 & $223: 6 \mathrm{~A}$ & Whole & $<185$ & $<189$ & $<187$ \\
\hline S97T002233 & \multirow[t]{2}{*}{$223: 7$} & Upper half & $<210$ & $<200$ & $<205$ \\
\hline S97T002232 & & Lower half & $<196$ & $<203$ & $<200$ \\
\hline S97T002235 & \multirow[t]{2}{*}{$223: 8$} & Upper half & $<203$ & $<202$ & $<203$ \\
\hline S97T002234 & & Lower half & $<198$ & $<201$ & $<200$ \\
\hline S98T000704 & $223: 9$ & Whole & $<202$ & $<204$ & $<203$ \\
\hline S97T002265 & \multirow[t]{2}{*}{$223: 10$} & Upper half & $<197$ & $<197$ & $<197$ \\
\hline S97T002263 & & Lower half & $<205$ & $<205$ & $<205$ \\
\hline S97T002320 & 224:1 & Lower half & $<190$ & $<185$ & $<188^{\mathrm{QC}: \mathrm{c}}$ \\
\hline S98T000717 & $224: 2$ & Whole & $<202$ & $<195$ & $<199$ \\
\hline S97T002334 & $224: 3$ & Lower half & $<183$ & $<185$ & $<184$ \\
\hline S98T000718 & $224: 4$ & Whole & $<201$ & $<199$ & $<200$ \\
\hline S97T002360 & \multirow[t]{2}{*}{$224: 5$} & Upper half & $<200$ & \begin{tabular}{|l|}
$<204$ \\
\end{tabular} & $<202$ \\
\hline S97T002359 & & Lower half & $<202$ & $<200$ & $<201^{\mathrm{QC}: \mathrm{c}}$ \\
\hline S97T002362 & \multirow[t]{2}{*}{$224: 6$} & Upper half & $<182$ & $<175$ & $<179$ \\
\hline S97T002361 & & Lower half & $<193$ & $<196$ & $<195$ \\
\hline
\end{tabular}


Table B2-36. Tank 241-SX-106 Analytical Results: Silver (ICP). (2 sheets)

\begin{tabular}{|c|c|c|c|c|c|}
\hline Sample: & S Sample & $\begin{array}{l}\text { Sample } \\
\text { fortion }\end{array}$ & Result & Duphleate & 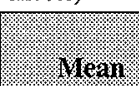 \\
\hline \multicolumn{3}{|c|}{ Gorids: fusion (Cont d) } & 9.9 .9 & $4.9 / \mathrm{g}$. & 莎 \\
\hline S98T000719 & $224: 7$ & Whole & $<193$ & $<200$ & $<197$ \\
\hline S97T002364 & \multirow[t]{2}{*}{$224: 8$} & Upper half & $<202$ & $<201$ & $<202$ \\
\hline S97T002363 & & Lower half & $<185$ & $<181$ & $<183$ \\
\hline S97T002392 & \multirow[t]{2}{*}{$224: 9$} & Upper half & $<219$ & $<219$ & $<219$ \\
\hline S97T002387 & & Lower half & $<223$ & $<224$ & $<224^{\mathrm{QC}: \mathrm{c}}$ \\
\hline S98T000720 & $224: 10$ & Whole & $<196$ & $<195$ & $<196$ \\
\hline S97T002402 & \multirow[t]{2}{*}{$224: 11$} & Upper half & $<201$ & $<201$ & $<201$ \\
\hline S97T002397 & & Lower half & $<197$ & $<192$ & $<195$ \\
\hline \multicolumn{2}{|l|}{ Whuids: } & 10 & (1.8/ & ( $19 \mathrm{~g} \cdot \mathrm{ru}$ & $1.8 \mathrm{~g} / 11$ \\
\hline S97T002179 & $223: 1$ & Drainable liquid & 16.7 & 15.7 & 16.2 \\
\hline S97T002188 & $223: 2$ & Drainable liquid & 17.5 & 16.1 & 16.8 \\
\hline S97T002199 & $223: 3$ & Drainable liquid & 18.5 & 18.2 & 18.4 \\
\hline S97T002200 & $223: 4$ & Drainable liquid & 19.2 & 17.6 & 18.4 \\
\hline S97T002215 & $223: 5$ & Drainable liquid & 18.6 & 17.6 & 18.1 \\
\hline$\$ 97 T 002323$ & $224: 1$ & Drainable liquid & 17.9 & 18.2 & $18^{\mathrm{QC}: \mathrm{c}}$ \\
\hline S97T002371 & $224: 3$ & Drainable liquid & 17.4 & 17.7 & 17.5 \\
\hline S97T002372 & $224: 5$ & Drainable liquid & 15.7 & 17 & $16.4^{\mathrm{QC:c}}$ \\
\hline
\end{tabular}


Table B2-37. Tank 241-SX-106 Analytical Results: Sodium (ICP). (2 sheets)

\begin{tabular}{|c|c|c|c|c|c|}
\hline Sample & Samples & Sample & Resilit: & Muplinate & Mean \\
\hline \multicolumn{2}{|c|}{ Soldst rexd fligest } & & $x g$ & 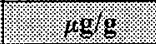 & $\%$ \\
\hline S98T000695 & 223:6 & Whole & $1.06 \mathrm{E}+05$ & $1.06 \mathrm{E}+05$ & $1.06 \mathrm{E}+05^{\mathrm{QC}: \mathrm{b}}$ \\
\hline S98T000705 & $223: 6 \mathrm{~A}$ & Whole & 97000 & $1.05 \mathrm{E}+05$ & $1.01 \mathrm{E}+05^{\mathrm{QC}: \mathrm{b}, \mathrm{c}}$ \\
\hline S98T000706 & $223: 9$ & Whole & $1.03 \mathrm{E}+05$ & $1.04 \mathrm{E}+05$ & $1.04 \mathrm{E}+05^{\mathrm{QC}: \mathrm{b}}$ \\
\hline S98T000721 & $224: 2$ & Whole & 89100 & 89700 & $89400^{\text {QC:b,d }}$ \\
\hline S98T000722 & $224: 4$ & Whole & 92400 & 91000 & $91700^{\mathrm{eC:b}}$ \\
\hline S98T000723 & $224: 7$ & Whole & $1.07 \mathrm{E}+05$ & $1.07 \mathrm{E}+05$ & $1.07 \mathrm{E}+05^{\mathrm{QC}: \mathrm{b}, \mathrm{d}}$ \\
\hline S98T000724 & $224: 10$ & Whole & $1.14 \mathrm{E}+05$ & $1.12 \mathrm{E}+05$ & $1.13 \mathrm{E}+05^{\mathrm{QC}: \mathrm{b}}$ \\
\hline \multicolumn{2}{|c|}{ Solvis t ritsion } & & . & (2.1. & 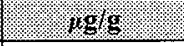 \\
\hline S97T002177 & $223: 1$ & Lower half & $2.14 \mathrm{E}+05$ & $2.03 \mathrm{E}+05$ & $2.09 \mathrm{E}+05$ \\
\hline S97T002185 & $223: 2$ & Lower half & $1.57 \mathrm{E}+05$ & $1.53 \mathrm{E}+05$ & $1.55 \mathrm{E}+05$ \\
\hline S97T002194 & $223: 3$ & Lower half & $2.05 \mathrm{E}+05$ & $2.03 \mathrm{E}+05$ & $2.04 \mathrm{E}+05^{\mathrm{QC}: \mathrm{d}}$ \\
\hline \$97T002204 & $223: 4$ & Lower half & $2.00 \mathrm{E}+05$ & $2.06 \mathrm{E}+05$ & $2.03 \mathrm{E}+05$ \\
\hline S97T002231 & $223: 5$ & Lower half & $1.62 \mathrm{E}+05$ & $1.62 \mathrm{E}+05$ & $1.62 \mathrm{E}+05$ \\
\hline S98T000694 & $223: 6$ & Whole & $1.07 \mathrm{E}+05$ & $1.04 \mathrm{E}+05$ & $1.06 \mathrm{E}+05$ \\
\hline S98T000703 & $223: 6 \mathrm{~A}$ & Whole & $1.01 \mathrm{E}+05$ & $1.03 \mathrm{E}+05$ & $1.02 \mathrm{E}+05$ \\
\hline S97T002233 & \multirow[t]{2}{*}{$223: 7$} & Upper half & $1.84 \mathrm{E}+05$ & $1.87 \mathrm{E}+05$ & $1.86 \mathrm{E}+05$ \\
\hline S97T002232 & & Lower half & $1.99 \mathrm{E}+05$ & $1.95 \mathrm{E}+05$ & $1.97 \mathrm{E}+05$ \\
\hline S97T002235 & \multirow[t]{2}{*}{$223: 8$} & Upper half & $1.84 \mathrm{E}+05$ & $1.82 \mathrm{E}+05$ & $1.83 \mathrm{E}+05$ \\
\hline S97T002234 & & Lower half & $2.12 \mathrm{E}+05$ & $2.11 \mathrm{E}+05$ & $2.12 \mathrm{E}+05$ \\
\hline S98T000704 & $223: 9$ & Whole & $1.05 \mathrm{E}+05$ & $1.04 \mathrm{E}+05$ & $1.05 \mathrm{E}+05$ \\
\hline \$97T002265 & \multirow[t]{2}{*}{$223: 10$} & Upper half & $2.12 \mathrm{E}+05$ & $2.19 \mathrm{E}+05$ & $2.16 \mathrm{E}+05$ \\
\hline \$97T002263 & & Lower half & $2.05 \mathrm{E}+05$ & $2.06 \mathrm{E}+05$ & $2.06 \mathrm{E}+05$ \\
\hline \$97T002320 & $224: 1$ & Lower half & $1.62 \mathrm{E}+05$ & $1.59 \mathrm{E}+05$ & $1.61 \mathrm{E}+05$ \\
\hline S98T000717 & $224: 2$ & Whole & 94,700 & 93,700 & 94,200 \\
\hline S97T002334 & $224: 3$ & Lower half & $1.60 \mathrm{E}+05$ & $1.57 \mathrm{E}+05$ & $1.59 \mathrm{E}+05$ \\
\hline \$98T000718 & $224: 4$ & Whole & $1.00 \mathrm{E}+05$ & $1.00 \mathrm{E}+05$ & $1.00 \mathrm{E}+05$ \\
\hline S97T002360 & \multirow[t]{2}{*}{$224: 5$} & Upper half & $1.78 \mathrm{E}+05$ & $1.58 \mathrm{E}+05$ & $1.68 \mathrm{E}+05$ \\
\hline S97T002359 & & Lower half & $1.68 \mathrm{E}+05$ & $1.72 \mathrm{E}+05$ & 1.70E+05 \\
\hline S97T002362 & \multirow[t]{2}{*}{$224: 6$} & Upper half & $1.81 \mathrm{E}+05$ & $1.80 \mathrm{E}+05$ & $1.81 \mathrm{E}+05$ \\
\hline S97T002361 & & Lower half & $1.69 \mathrm{E}+05$ & $1.72 \mathrm{E}+05$ & $1.71 \mathrm{E}+05$ \\
\hline
\end{tabular}


Table B2-37. Tank 241-SX-106 Analytical Results: Sodium (ICP). (2 sheets)

\begin{tabular}{|c|c|c|c|c|c|}
\hline $\begin{array}{l}\text { Sample } \\
\text { Number }\end{array}$ & $\begin{array}{l}\text { Sample } \\
\text { Iocation }\end{array}$ & $\begin{array}{l}\text { Sampie } \\
\text { Portion }\end{array}$ & Result & Ouplease & Mean \\
\hline \multicolumn{3}{|c|}{ Solids rusion (Gont di) } & 1.969 & $10.98 \%$ & 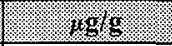 \\
\hline S98T000719 & $224: 7$ & Whole & $1.03 \mathrm{E}+05$ & $1.03 \mathrm{E}+05$ & $1.03 \mathrm{E}+05$ \\
\hline S97T002364 & \multirow[t]{2}{*}{$224: 8$} & Upper half & $2.04 \mathrm{E}+05$ & $2.10 \mathrm{E}+05$ & $2.07 \mathrm{E}+05$ \\
\hline S97T002363 & & Lower half & $2.01 \mathrm{E}+05$ & $2.08 \mathrm{E}+05$ & $2.05 \mathrm{E}+05^{\mathrm{QC}: \mathrm{c}}$ \\
\hline S97T002392 & \multirow[t]{2}{*}{$224: 9$} & Upper half & $2.08 \mathrm{E}+05$ & $2.10 \mathrm{E}+05$ & $2.09 \mathrm{E}+05$ \\
\hline \$97T002387 & & Lower half & $1.92 \mathrm{E}+05$ & $1.93 \mathrm{E}+05$ & $1.93 \mathrm{E}+05$ \\
\hline S98T000720 & $224: 10$ & Whole & $1.08 \mathrm{E}+05$ & $1.10 \mathrm{E}+05$ & $1.09 \mathrm{E}+05$ \\
\hline$\$ 97 T 002402$ & \multirow[t]{2}{*}{$224: 11$} & Upper half & $1.82 \mathrm{E}+05$ & $1.81 \mathrm{E}+05$ & $1.82 \mathrm{E}+05$ \\
\hline S97T002397 & & Lower half & $2.16 \mathrm{E}+05$ & $2.07 \mathrm{E}+05$ & $2.12 \mathrm{E}+05$ \\
\hline Trivinas: & & & $.10 \mathrm{~g} / \mathrm{mi}$ & $=0.48 \mathrm{mo}$ & \%. $10 . \mathrm{mu}$ \\
\hline S97T002179 & 223:1 & Drainable liquid & $2.40 \mathrm{E}+05$ & $2.28 \mathrm{E}+05$ & $2.34 \mathrm{E}+05$ \\
\hline S97T002188 & $223: 2$ & Drainable liquid & $2.43 \mathrm{E}+05$ & $2.27 \mathrm{E}+05$ & $2.35 \mathrm{E}+05$ \\
\hline \$97T002199 & 223:3 & Drainable liquid & $2.45 \mathrm{E}+05$ & $2.46 \mathrm{E}+05$ & $2.46 \mathrm{E}+05^{\mathrm{QC}: c}$ \\
\hline S97T002200 & $223: 4$ & Drainable liquid & $2.53 \mathrm{E}+05$ & $2.40 \mathrm{E}+05$ & $2.47 \mathrm{E}+05^{\mathrm{QC}: c}$ \\
\hline S97T002215 & $223: 5$ & Drainable liquid & $2.60 \mathrm{E}+05$ & $2.50 \mathrm{E}+05$ & $2.55 \mathrm{E}+05$ \\
\hline S97T002323 & 224:1 & Drainable liquid & $2.64 \mathrm{E}+05$ & $2.70 \mathrm{E}+05$ & $2.67 \mathrm{E}+05^{\mathrm{QC}: \mathrm{c}}$ \\
\hline S97T002371 & $224: 3$ & Drainable liquid & $2.44 \mathrm{E}+05$ & $2.45 \mathrm{E}+05$ & $2.45 \mathrm{E}+05$ \\
\hline \$97T002372 & $224: 5$ & Drainable liquid & $2.30 \mathrm{E}+05$ & $2.35 \mathrm{E}+05$ & $2.33 \mathrm{E}+05^{\mathrm{QC:d}}$ \\
\hline
\end{tabular}


Table B2-38. Tank 241-SX-106 Analytical Results: Strontium (ICP). (2 sheets)

\begin{tabular}{|c|c|c|c|c|c|}
\hline Sample & $\begin{array}{l}\text { Sample. } \\
\text { Location. }\end{array}$ & $\begin{array}{l}\text { Sanple } \\
\text { rovion }\end{array}$ & Rerult & Buplicate. & Mean \\
\hline \multicolumn{2}{|c|}{ Solids: acid digest } & 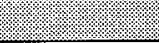 & (3. & $109 \mathrm{~g}$, & $1.10 \mathrm{~g} / \mathrm{g} / \mathrm{s}$ \\
\hline S98T000695 & $223: 6$ & Whole & $<4.01$ & $<3.76$ & $<3.88$ \\
\hline S98T000705 & $223: 6 \mathrm{~A}$ & Whole & $<3.75$ & $<3.93$ & $<3.84$ \\
\hline S98T000706 & $223: 9$ & Whole & $<3.8$ & $<3.76$ & $<3.78$ \\
\hline S98T000721 & $224: 2$ & Whole & $<2.42$ & $<1.75$ & $<2.08$ \\
\hline S98T000722 & $224: 4$ & Whole & $<1.94$ & $<1.92$ & $<1.93$ \\
\hline S98T000723 & $224: 7$ & Whole & $<3.93$ & $<3.88$ & $<3.91$ \\
\hline S98T000724 & $224: 10^{\circ}$ & Whole & $<3.6$ & $<3.53$ & $<3.56$ \\
\hline \multicolumn{2}{|c|}{ Solids fusion } & & 1.98 .9 & 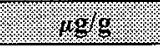 & $1.18 \%$ \\
\hline S97T002177 & $223: 1$ & Lower half & $<208$ & $<204$ & $<206$ \\
\hline S97T002185 & $223: 2$ & Lower half & $<192$ & $<189$ & $<191$ \\
\hline S97T002194 & $223: 3$ & Lower half & $<188$ & $<187$ & $<188$ \\
\hline S97T002204 & $223: 4$ & Lower half & $<220$ & $<215$ & $<218$ \\
\hline S97T002231 & $223: 5$ & Lower half & $<184$ & $<190$ & $<187$ \\
\hline S98T000694 & $223: 6$ & Whole & $<193$ & $<189$ & $<191$ \\
\hline S98T000703 & $223: 6 \mathrm{~A}$ & Whole & $<185$ & $<189$ & $<187$ \\
\hline S97T002233 & \multirow[t]{2}{*}{$223: 7$} & Upper half & $<210$ & $<200$ & $<205$ \\
\hline S97T002232 & & Lower half & $<196$ & $<203$ & $<200$ \\
\hline S97T002235 & \multirow[t]{2}{*}{$223: 8$} & Upper half & $<203$ & $<202$ & $<203$ \\
\hline S97T002234 & & Lower half & $<198$ & $<201$ & $<200$ \\
\hline S98T000704 & $223: 9$ & Whole & $<202$ & $<204$ & $<203$ \\
\hline S97T002265 & \multirow[t]{2}{*}{$223: 10$} & Upper half & \begin{tabular}{|l|}
$<197$ \\
\end{tabular} & \begin{tabular}{|l|}
$<197$ \\
\end{tabular} & $<197$ \\
\hline S97T002263 & & Lower half & $<205$ & $<205$ & $<205$ \\
\hline S97T002320 & 224:1 & Lower half & $<190$ & $<185$ & $<188$ \\
\hline S98T000717 & $224: 2$ & Whole & $<202$ & $<195$ & $<199$ \\
\hline S97T002334 & $224: 3$ & Lower half & $<183$ & $<185$ & $<184$ \\
\hline S98T000718 & $224: 4$ & Whole & $<201$ & $<199$ & $<200$ \\
\hline S97T002360 & \multirow[t]{2}{*}{$224: 5$} & Upper half & $<200$ & $<204$ & $<202$ \\
\hline S97T002359 & & Lower half & $<202$ & $<200$ & $<201$ \\
\hline S97T002362 & \multirow[t]{2}{*}{$224: 6$} & Upper half & $<182$ & $<175$ & $<179$ \\
\hline S97T002361 & & Lower half & $<193$ & $<196$ & $<195$ \\
\hline
\end{tabular}


HNF-SD-WM-ER-645 Rev. 1

Table B2-38. Tank 241-SX-106 Analytical Results: Strontium (ICP). (2 sheets)

\begin{tabular}{|c|c|c|c|c|c|}
\hline $\begin{array}{l}\text { Sample } \\
\text { Number }\end{array}$ & $\begin{array}{l}\text { Sample } \\
\text { L Location }\end{array}$ & $\begin{array}{l}\text { Sample } \\
\text { I trationt }\end{array}$ & Result: & Drolloris & Meri: : \\
\hline \multicolumn{2}{|c|}{ Solits fusion (Coni a) } & 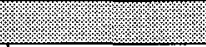 & 1.989 & $411 \mathrm{~g} / \mathrm{g}=$ & $.4 \mathrm{~g} g$ \\
\hline S98T000719 & $224: 7$ & Whole & $<193$ & $<200$ & $<197$ \\
\hline S97T002364 & \multirow[t]{2}{*}{$224: 8$} & Upper half & $<202$ & $<201$ & $<202$ \\
\hline S97T002363 & & Lower half & $<185$ & $<181$ & $<183$ \\
\hline S97T002392 & \multirow[t]{2}{*}{$224: 9$} & Upper half & $<219$ & $<219$ & $<219$ \\
\hline S97T002387 & & Lower half & $<223$ & $<224$ & $<224$ \\
\hline S98T000720 & $224: 10$ & Whole & $<196$ & $<195$ & $<196$ \\
\hline S97T002402 & \multirow[t]{2}{*}{$224: 11$} & Upper half & $<201$ & $<201$ & $<201$ \\
\hline S97T002397 & & Lower half & $<197$ & $<192$ & $<195$ \\
\hline \multicolumn{2}{|l|}{ Minuids : } & $\sin (5)$ & . & $1 . \mathrm{g} \operatorname{lng}$ & (19uil: \\
\hline S97T002179 & 223:1 & Drainable liquid & $<6.01$ & $<6.01$ & $<6.01$ \\
\hline S97T002188 & $223: 2$ & Drainable liquid & $<6.01$ & $<6.01$ & $<6.01$ \\
\hline S97T002199 & $223: 3$ & Drainable liquid & $<6.01$ & $<6.01$ & $<6.01$ \\
\hline S97T002200 & 223:4 & Drainable liquid & $<6.01$ & $<6.01$ & $<6.01$ \\
\hline S97T002215 & $223: 5$ & Drainable liquid & $<6.01$ & $<6.01$ & $<6.01$ \\
\hline S97T002323 & $224: 1$ & Drainable liquid & $<6.01$ & $<6.01$ & $<6.01$ \\
\hline S97T002371 & $224: 3$ & Drainable liquid & $<6.01$ & $<6.01$ & $<6.01$ \\
\hline S97T002372 & $224: 5$ & Drainable liquid & $<6.01$ & $<6.01$ & $<6.01$ \\
\hline
\end{tabular}


HNF-SD-WM-ER-645 Rev. 1

Table B2-39. Tank 241-SX-106 Analytical Results: Sulfur (ICP). (2 sheets)

\begin{tabular}{|c|c|c|c|c|c|}
\hline Maminer & \%oarulo & $6.110 \mathrm{plc}$ & $\mathrm{gesul}$ & 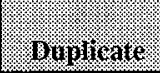 & Mera \\
\hline \multicolumn{2}{|c|}{ Sollits ardidilgest. } & 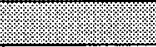 & 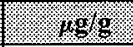 & 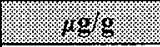 & . \\
\hline S98T000695 & $223: 6$ & Whole & 2,190 & 2,200 & 2,200 \\
\hline S98T000705 & $223: 6 \mathrm{~A}$ & Whole & 1,710 & 717 & $1210^{\mathrm{ec}: \mathrm{e}}$ \\
\hline S98T000706 & $223: 9$ & Whole & 692 & 688 & 690 \\
\hline S98T000721 & $224: 2$ & Whole & 735 & 746 & 741 \\
\hline$\$ 98 T 000722$ & $224: 4$ & Whole & 772 & 775 & 774 \\
\hline S98T000723 & $224: 7$ & Whole & 1,680 & 1,690 & 1,690 \\
\hline S98T000724 & $224: 10$ & Whole & 1,250 & 1,250 & 1,250 \\
\hline \multicolumn{2}{|c|}{ 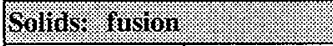 } & & mo & gog & 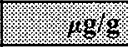 \\
\hline S97T002177 & $223: 1$ & Lower half & $<2,080$ & $<2,040$ & $<2,060$ \\
\hline S97T002185 & $223: 2$ & Lower half & $<1,920$ & $<1,890$ & $<1,910$ \\
\hline S97T002194 & $223: 3$ & Lower half & $<1,880$ & $<1,870$ & $<1,880$ \\
\hline S97T002204 & $223: 4$ & Lower half & $<2,200$ & $<2,150$ & $<2,180$ \\
\hline S97T002231 & $223: 5$ & Lower half & $<1,840$ & $<1,900$ & $<1,870$ \\
\hline S98T000694 & $223: 6$ & Whole & 2,170 & 1,980 & 2,080 \\
\hline S98T000703 & $223: 6 \mathrm{~A}$ & Whole & $<1,850$ & $<1,890$ & $<1,870$ \\
\hline \$97T002233 & \multirow[t]{2}{*}{$223: 7$} & Upper half & 3,320 & 3,200 & 3,260 \\
\hline S97T002232 & & Lower half & 1,990 & 2,050 & 2,020 \\
\hline S97T002235 & \multirow[t]{2}{*}{$223: 8$} & Upper half & $<2,030$ & $<2,020$ & $<2,030$ \\
\hline S97T002234 & & Lower half & $<1,980$ & $<2,010$ & $<2,000$ \\
\hline S98T000704 & $223: 9$ & Whole & $<2,020$ & $<2,040$ & $<2,030$ \\
\hline S97T002265 & \multirow[t]{2}{*}{$223: 10$} & Upper half & $<1,970$ & $<1,970$ & $<1,970$ \\
\hline S97T002263 & & Lower half & 4,290 & 3,120 & $3,710^{\mathrm{eC}: \mathrm{e}}$ \\
\hline S97T002320 & $224: 1$ & Lower half & $<1,900$ & $<1,850$ & $<1,880$ \\
\hline S98T000717 & $224: 2$ & Whole & $<2,020$ & $<1,950$ & $<1,990$ \\
\hline S97T002334 & $224: 3$ & Lower half & $<1,830$ & $<1,850$ & $<1,840$ \\
\hline S98T000718 & $224: 4$ & Whole & $<2,010$ & $<1,990$ & $<2,000$ \\
\hline$\$ 97 \mathrm{~T} 002360$ & \multirow[t]{2}{*}{$224: 5$} & Upper half & $<2,000$ & $<2,040$ & $<2,020$ \\
\hline S97T002359 & & Lower half & 3,090 & 3,180 & 3,140 \\
\hline S97T002362 & \multirow[t]{2}{*}{$224: 6$} & Upper half & 2,420 & 2,750 & 2,590 \\
\hline \$97T002361 & & Lower half & 2,260 & 2,620 & 2,440 \\
\hline
\end{tabular}


Table B2-39. Tank 241-SX-106 Analytical Results: Sulfur (ICP). (2 sheets)

\begin{tabular}{|c|c|c|c|c|c|}
\hline $\begin{array}{l}\text { Sampie } \\
\text { Vimber }\end{array}$ & $\begin{array}{l}\text { Sariple. } \\
\text { Goeation }\end{array}$ & $\begin{array}{l}\text { Sample } \\
\text { Tontion }\end{array}$ & Result & Bupleates. & Mean \\
\hline \multicolumn{3}{|c|}{ Sollds wisin (con id) } & 1.9919 & 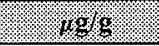 & 8.1498 \\
\hline S98T000719 & $224: 7$ & Whole & $<1,930$ & $<2,000$ & $<1,970$ \\
\hline S97T002364 & \multirow[t]{2}{*}{$224: 8$} & Upper half & 2,260 & $<2,010$ & $<2,140$ \\
\hline S97T002363 & & Lower half & 1,950 & $<1,810$ & $<1 ; 880$ \\
\hline S97T002392 & \multirow[t]{2}{*}{$224: 9$} & Upper half & $<2,190$ & $<2,190$ & $<2,190$ \\
\hline S97T002387 & & Lower half & $<2,230$ & $<2,240$ & $<2,240$ \\
\hline S98T000720 & $224: 10$ & Whole & $<1,960$ & $<1,950$ & $<1,960$ \\
\hline S97T002402 & \multirow[t]{2}{*}{$224: 11$} & Upper half & $<2,010$ & $<2,010$ & $<2,010$ \\
\hline S97T002397 & & Lower half & $<1,970$ & $<1,920$ & $<1,950$ \\
\hline \multicolumn{3}{|l|}{ Erguris: } & 1064111 & 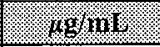 & 2.ginu \\
\hline S97T002179 & $223: 1$ & Drainable liquid & 2,340 & 2,260 & 2,300 \\
\hline S97T002188 & $223: 2$ & Drainable liquid & 2,330 & 2,200 & 2,270 \\
\hline S97T002199 & $223: 3$ & Drainable liquid & 2,440 & 2,440 & $2,440^{\mathrm{eC}: \mathrm{c}}$ \\
\hline S97T002200 & $223: 4$ & Drainable liquid & 2,490 & 2,390 & $2,440^{\mathrm{ec}: \mathrm{c}}$ \\
\hline S97T002215 & $223: 5$ & Drainable liquid & 2,430 & 2,490 & 2,460 . \\
\hline S97T002323 & $224: 1$ & Drainable liquid & 2,510 & 2,530 & 2,520 \\
\hline S97T002371 & $224: 3$ & Drainable liquid & 2,360 & 2,400 & 2,380 \\
\hline S97T002372 & $224: 5$ & Drainable liquid & 2,380 & 2,420 & 2,400 \\
\hline
\end{tabular}


Table B2-40. Tank 241-SX-106 Analytical Results: Thallium (ICP). (2 sheets)

\begin{tabular}{|c|c|c|c|c|c|}
\hline $\begin{array}{l}\text { Sample= } \\
\text { Vimber }\end{array}$ & $\begin{array}{l}\text { Sample } \\
\text { gocation }\end{array}$ & Sample & Rresuit & Oupleare & Merin \\
\hline \multicolumn{3}{|c|}{ Solids: act digest } & 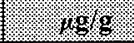 & 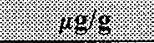 & 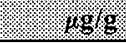 \\
\hline S98T000695 & $223: 6$ & Whole & $<80.3$ & $<75.2$ & $<77.8$ \\
\hline S98T000705 & $223: 6 \mathrm{~A}$ & Whole & $<75$ & $<78.6$ & $<76.8$ \\
\hline S98T000706 & $223: 9$ & Whole & $<76$ & $<75.2$ & $<75.6$ \\
\hline \$98T000721 & $224: 2$ & Whole & $<48.4$ & $<35.1$ & $<41.8$ \\
\hline S98T000722 & $224: 4$ & Whole & $<38.9$ & $<38.3$ & $<38.6$ \\
\hline S98T000723 & $224: 7$ & Whole & $<78.6$ & $<77.6$ & $<78.1$ \\
\hline S98T000724 & $224: 10$ & Whole & $<72$ & $<70.6$ & $<71.3$ \\
\hline \multicolumn{2}{|c|}{ Solids: guston : } & & 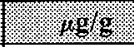 & 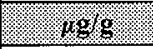 & 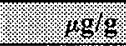 \\
\hline S97T002177 & $223: 1$ & Lower half & $<4,160$ & $<4,070$ & $<4,120$ \\
\hline S97T002185 & $223: 2$ & Lower half & $<3,830$ & $<3,780$ & $<3,810$ \\
\hline S97T002194 & $223: 3$ & Lower half & $<3,760$ & $<3,730$ & $<3,750$ \\
\hline S97T002204 & $223: 4$ & Lower half & $<4,400$ & $<4,300$ & $<4,350$ \\
\hline S97T002231 & $223: 5$ & Lower half & $<3,690$ & $<3,800$ & $<3,750$ \\
\hline S98T000694 & $223: 6$ & Whole & $<3,860$ & $<3,780$ & $<3,820$ \\
\hline S98T000703 & $223: 6 \mathrm{~A}$ & Whole & $<3,700$ & $<3,770$ & $<3,740$ \\
\hline S97T002233 & \multirow[t]{2}{*}{$223: 7$} & Upper half & $<4,200$ & $<4,010$ & $<4,110$ \\
\hline S97T002232 & & Lower half & $<3,920$ & $<4,060$ & $<3,990$ \\
\hline S97T002235 & \multirow[t]{2}{*}{$223: 8$} & Upper half & $<4,050$ & $<4,040$ & $<4,050$ \\
\hline S97T002234 & & Lower half & $<3,970$ & $<4,010$ & $<3,990$ \\
\hline S98T000704 & $223: 9$ & Whole & $<4,040$ & $<4,080$ & $<4,060$ \\
\hline S97T002265 & \multirow[t]{2}{*}{$223: 10$} & Upper half & $<3,940$ & $<3,930$ & $<3,940$ \\
\hline S97T002263 & & Lower half & $<4,100$ & $<4,100$ & $<4,100$ \\
\hline S97T002320 & $224: 1$ & Lower half & $<3,800$ & $<3,690$ & $<3,750$ \\
\hline S98T000717 & $224: 2$ & Whole & $<4,050$ & $<3,900$ & $<3,980$ \\
\hline S97T002334 & $224: 3$ & Lower half & $<3,660$ & $<3,690$ & $<3,680$ \\
\hline S98T000718 & $224: 4$ & Whole & $<4,030$ & $<3,980$ & $<4,010$ \\
\hline S97T002360 & \multirow[t]{2}{*}{$224: 5$} & Upper half & $<4,000$ & $<4,070$ & $<4,040$ \\
\hline S97T002359 & & Lower half & $<4,040$ & $<4,000$ & $<4,020$ \\
\hline S97T002362 & \multirow[t]{2}{*}{$224: 6$} & Upper half & $<3,640$ & $<3,490$ & $<3,570$ \\
\hline S97T002361 & & Lower half & $<3,870$ & $<3,910$ & $<3,890$ \\
\hline
\end{tabular}


Table B2-40. Tank 241-SX-106 Analytical Results: Thallium (ICP). (2 sheets)

\begin{tabular}{|c|c|c|c|c|c|}
\hline Samis & samplo & 6ample & Krosull & Bruluate & tran \\
\hline \multicolumn{3}{|c|}{ 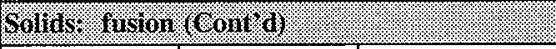 } & 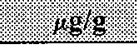 & 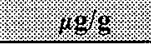 & 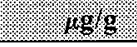 \\
\hline S98T000719 & $224: 7$ & Whole & $<3,870$ & $<4,000$ & $<3,940$ \\
\hline \$97T002364 & \multirow[t]{2}{*}{$224: 8$} & Upper half & $<4,040$ & $<4,010$ & $<4,030$ \\
\hline \$97T002363 & & Lower half & $<3,690$ & $<3,620$ & $<3,660$ \\
\hline \$97T002392 & \multirow[t]{2}{*}{$224: 9$} & Upper half & $<4,370$ & $<4,380$ & $<4,380$ \\
\hline \$97T002387 & & Lower half & $<4,470$ & $<4,480$ & $<4,480$ \\
\hline \$98T000720 & $224: 10$ & Whole & $<3,930$ & $<3,900$ & $<3,920$ \\
\hline \$97T002402 & \multirow[t]{2}{*}{$224: 11$} & Upper half & $<4,020$ & $<4,010$ & $<4,020$ \\
\hline S97T002397 & & Lower half & $<3,940$ & $<3,850$ & $<3,900$ \\
\hline 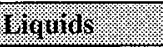 & & & oglan & (1) 1418 & . \\
\hline S97T002179 & $223: 1$ & Drainable liquid & $<120$ & $<120$ & $<120$ \\
\hline S97T002188 & $223: 2$ & Drainable liquid & $<120$ & $<120$ & $<120$ \\
\hline S97T002199 & $223: 3$ & Drainable liquid & $<120$ & $<120$ & $<120$ \\
\hline S97T002200 & $223: 4$ & Drainable liquid & $<120$ & $<120$ & $<120$ \\
\hline \$97T002215 & $223: 5$ & Drainable liquid & $<120$ & $<120$ & $<120$ \\
\hline S97T002323 & $224: 1$ & Drainable liquid & $<120$ & $<120$ & $<120$ \\
\hline S97T002371 & $224: 3$ & Drainable liquid & $<120$ & $<120$ & $<120$ \\
\hline \$97T002372 & $224: 5$ & Drainable liquid & $<120$ & $<120$ & $<120$ \\
\hline
\end{tabular}


HNF-SD-WM-ER-645 Rev. 1

Table B2-41. Tank 241-SX-106 Analytical Results: Titanium (ICP). (2 sheets)

\begin{tabular}{|c|c|c|c|c|c|}
\hline Sample & $\begin{array}{l}\text { Samivle } \\
\text { I oration }\end{array}$ & $\begin{array}{l}\text { Sample } \\
\text { Sortion }\end{array}$ & aresule & Minglicalo & yean \\
\hline \multicolumn{3}{|c|}{ Solids: acid digest } & 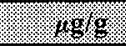 & $1,19 \mathrm{~g}$ & 108 \\
\hline S98T000695 & $223: 6$ & Whole & $<4.01$ & $<3.76$ & $<3.88$ \\
\hline S98T000705 & $223: 6 \mathrm{~A}$ & Whole & $<3.75$ & $<3.93$ & $<3.84$ \\
\hline S98T000706 & $223: 9$ & Whole & $<3.8$ & $<3.76$ & $<3.78$ \\
\hline S98T000721 & $224: 2$ & Whole & $<2.42$ & $<1.75$ & $<2.08$ \\
\hline S98T000722 & $224: 4$ & Whole & $<1.94$ & $<1.92$ & $<1.93$ \\
\hline S98T000723 & $224: 7$ & Whole & $<3.93$ & $<3.88$ & $<3.91$ \\
\hline S98T000724 & $224: 10$ & Whole & $<3.6$ & $<3.53$ & $<3.56$ \\
\hline \multicolumn{2}{|c|}{ Solide: iusion : } & S: & 1.989 & $10 \mathrm{~g} / \mathrm{g}$ & 1.96 \\
\hline S97T002177 & 223:1 & Lower half & $<208$ & $<204$ & $<206$ \\
\hline S97T002185 & $223: 2$ & Lower half & $<192$ & $<189$ & $<191$ \\
\hline S97T002194 & $223: 3$ & Lower half & $<188$ & $<187$ & $<188$ \\
\hline S97T002204 & $223: 4$ & Lower half & $<220$ & $<215$ & $<218$ \\
\hline S97T002231 & $223: 5$ & Lower half & $<184$ & $<190$ & $<187$ \\
\hline S98T000694 & $223: 6$ & Whole & $<193$ & $<189$ & $<191$ \\
\hline S98T000703 & $223: 6 \mathrm{~A}$ & Whole & $<185$ & $<189$ & $<187$ \\
\hline S97T002233 & \multirow[t]{2}{*}{$223: 7$} & Upper half & $<210$ & $<200$ & $<205$ \\
\hline S97T002232 & & Lower half & $<196$ & $<203$ & $<200$ \\
\hline S97T002235 & \multirow[t]{2}{*}{$223: 8$} & Upper half & $<203$ & $<202$ & $<203$ \\
\hline S97T002234 & & Lower half & $<198$ & $<201$ & $<200$ \\
\hline S98T000704 & $223: 9$ & Whole & $<202$ & $<204$ & $<203$ \\
\hline S97T002265 & \multirow[t]{2}{*}{$223: 10$} & Upper half & $<197$ & $<197$ & $<197$ \\
\hline S97T002263 & & Lower half & $<205$ & $<205$ & $<205$ \\
\hline S97T002320 & $224: 1$ & Lower half & $<190$ & $<185$ & $<188$ \\
\hline S98T000717 & $224: 2$ & Whole & $<202$ & $<195$ & $<199$ \\
\hline S97T002334 & $224: 3$ & Lower half & $<183$ & $<185$ & $<184$ \\
\hline S98T000718 & $224: 4$ & Whole & $<201$ & $<199$ & $<200$ \\
\hline S97T002360 & \multirow[t]{2}{*}{$224: 5$} & Upper half & $<200$ & $<204$ & $<202$ \\
\hline S97T002359 & & Lower half & $<202$ & $<200$ & $<201$ \\
\hline
\end{tabular}


Table B2-41. Tank 241-SX-106 Analytical Results: Titanium (ICP). (2 sheets)

\begin{tabular}{|c|c|c|c|c|c|}
\hline $\begin{array}{l}\text { Samile } \\
\text { Number }\end{array}$ & $\begin{array}{l}\text { Samile } \\
\text { I gration }\end{array}$ & $\begin{array}{l}\text { Sample } \\
\text { Fortion }\end{array}$ & Resull & Horilicule & Mran \\
\hline \multicolumn{3}{|c|}{ Solnds: Iusion (Cont d) ? } & 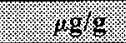 & 109.9 & H. \\
\hline S97T002362 & \multirow[t]{2}{*}{$224: 6$} & Upper half & $<182$ & $<175$ & $<179$ \\
\hline S97T002361 & & Lower half & $<193$ & $<196$ & $<195$ \\
\hline S98T000719 & $224: 7$ & Whole & $<193$ & $<200$ & $<197$ \\
\hline S97T002364 & \multirow[t]{2}{*}{$224: 8$} & Upper half & $<202$ & $<201$ & $<202$ \\
\hline S97T002363 & & Lower half & $<185$ & $<181$ & $<183$ \\
\hline S97T002392 & \multirow[t]{2}{*}{$224: 9$} & Upper half & $<219$ & $<219$ & $<219$ \\
\hline S97T002387 & & Lower half & $<223$ & $<224$ & $<224$ \\
\hline S98T000720 & $224: 10$ & Whole & $<196$ & $<195$ & $<196$ \\
\hline S97T002402 & \multirow[t]{2}{*}{$224: 11$} & Upper half & $<201$ & $<201$ & $<201$ \\
\hline S97T002397 & & Lower half & $<197$ & $<192$ & $<195$ \\
\hline \multicolumn{3}{|l|}{ Hapids: } & . 19 /111 & 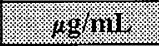 & 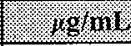 \\
\hline S97T002179 & $223: 1$ & Drainable liquid & $<6.01$ & $<6.01$ & $<6.01$ \\
\hline S97T002188 & $223: 2$ & Drainable liquid & $<6.01$ & $<6.01$ & $<6.01$ \\
\hline S97T002199 & $223: 3$ & Drainable liquid & $<6.01$ & $<6.01$ & $<6.01$ \\
\hline S97T002200 & $223: 4$ & Drainable liquid & $<6.01$ & $<6.01$ & $<6.01$ \\
\hline S97T002215 & $223: 5$ & Drainable liquid & $<6.01$ & $<6.01$ & $<6.01$ \\
\hline S97T002323 & $224: 1$ & Drainable liquid & $<6.01$ & $<6.01$ & $<6.01$ \\
\hline S97T002371 & $224: 3$ & Drainable liquid & $<6.01$ & $<6.01$ & $<6.01$ \\
\hline S97T002372 & $224: 5$ & Drainable liquid & $<6.01$ & $<6.01$ & $<6.01$ \\
\hline
\end{tabular}


HNF-SD-WM-ER-645 Rev. 1

Table B2-42. Tank 241-SX-106 Analytical Results: Total Uranium (ICP). (2 sheets)

\begin{tabular}{|c|c|c|c|c|c|}
\hline $\begin{array}{l}\text { Sample } \\
\text { Number. }\end{array}$ & $\begin{array}{l}\text { Sample } \\
\text { Lecation }\end{array}$ & $\begin{array}{l}\text { Sample } \\
\text { fortion }\end{array}$ & resull: & Buplicure & mean \\
\hline \multicolumn{3}{|c|}{ Solids: acill digest } & 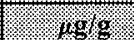 & $118 \% 8$ & $\log _{0}$ \\
\hline S98T000695 & $223: 6$ & Whole & $<201$ & $<188$ & $<195$ \\
\hline S98T000705 & $223: 6 \mathrm{~A}$ & Whole & $<187$ & $<196$ & $<192$ \\
\hline S98T000706 & $223: 9$ & Whole & $<190$ & $<188$ & $<189$ \\
\hline S98T000721 & $224: 2$ & Whole & $<121$ & $<87.6$ & $<104$ \\
\hline S98T000722 & $224: 4$ & Whole & $<97.2$ & $<95.8$ & $<96.5$ \\
\hline S98T000723 & $224: 7$ & Whole & $<197$ & $<194$ & $<196$ \\
\hline S98T000724 & $224: 10$ & Whole & 194 & 191 & 193 \\
\hline \multicolumn{2}{|c|}{ Solits: fision: } & & 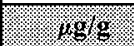 & $4.189 \mathrm{c}$ & 1.989 \\
\hline S97T002177 & $223: 1$ & Lower half & $<10,400$ & $<10,200$ & $<10,300$ \\
\hline S97T002185 & $223: 2$ & Lower half & $<9,580$ & $<9,460$ & $<9,520$ \\
\hline S97T002194 & $223: 3$ & Lower half & $<9,390$ & $<9,340$ & $<9,370$ \\
\hline S97T002204 & $223: 4$ & Lower half & $<11,000$ & $<10,700$ & $<10,900$ \\
\hline S97T002231 & $223: 5$ & Lower half & $<9,220$ & $<9,510$ & $<9,370$ \\
\hline S98T000694 & $223: 6$ & Whole & $<9,650$ & $<9,460$ & $<9,560$ \\
\hline$\$ 98 T 000703$ & $223: 6 \mathrm{~A}$ & Whole & $<9,260$ & $<9,430$ & $<9,350$ \\
\hline S97T002233 & \multirow[t]{2}{*}{$223: 7$} & Upper half & $<10,500$ & $<10,000$ & $<10,300$ \\
\hline S97T002232 & & Lower half & $<9,790$ & $<10,100$ & $<9,950$ \\
\hline S97T002235 & \multirow[t]{2}{*}{$223: 8$} & Upper half & $<10,100$ & $<10,100$ & $<10,100$ \\
\hline S97T002234 & & Lower half & $<9,920$ & $<10,000$ & $<9,960$ \\
\hline S98T000704 & $223: 9$ & Whole & $<10,100$ & $<10,200$ & $<10,200$ \\
\hline S97T002265 & \multirow[t]{2}{*}{$223: 10$} & Upper half & $<9,850$ & $<9,840$ & $<9,850$ \\
\hline S97T002263 & & Lower half & $<10,200$ & $<10,300$ & $<10,300$ \\
\hline S97T002320 & $224: 1$ & Lower half & $<9,500$ & $<9,230$ & $<9,370$ \\
\hline S98T000717 & $224: 2$ & Whole & $<10,100$ & $<9,760$ & $<9,930$ \\
\hline S97T002334 & $224: 3$ & Lower half & $<9,140$ & $<9,230$ & $<9,190$ \\
\hline S98T000718 & $224: 4$ & Whole & $<10,100$ & $<9,950$ & $<10,000$ \\
\hline S97T002360 & \multirow[t]{2}{*}{$224: 5$} & Upper half & $<9,990$ & $<10,200$ & $<10,100$ \\
\hline S97T002359 & & Lower half & $<10,100$ & $<9,990$ & $<10,000$ \\
\hline S97T002362 & \multirow[t]{2}{*}{$224: 6$} & Upper half & $<9,100$ & $<8,730$ & $<8,920$ \\
\hline S97T002361 & & Lower half & $<9,670$ & $<9,780$ & $<9,730$ \\
\hline
\end{tabular}


Table B2-42. Tank 241-SX-106 Analytical Results: Total Uranium (ICP). (2 sheets)

\begin{tabular}{|c|c|c|c|c|c|}
\hline $\begin{array}{l}\text { Sample. } \\
\text { Vunber }\end{array}$ & $\begin{array}{l}\text { Sample. } \\
\text { Togation }\end{array}$ & $\begin{array}{l}\text { Sample } \\
\text { rortion }\end{array}$ & Result. & Buplicate & yean \\
\hline \multicolumn{3}{|c|}{ Solids: Gasion (Cont d) } & 1096 & 10.96. & $1+9.9$ \\
\hline S98T000719 & $224: 7$ & Whole & $<9,670$ & $<9,990$ & $<9,830$ \\
\hline S97T002364 & \multirow[t]{2}{*}{$224: 8$} & Upper half & $<10,100$ & $<10,000$ & $<10,100$ \\
\hline S97T002363 & & Lower half & $<9,230$ & $<9,050$ & $<9,140$ \\
\hline S97T002392 & \multirow[t]{2}{*}{$224: 9$} & Upper half & $<10,900$ & $<11,000$ & $<11,000$ \\
\hline S97T002387 & & Lower half & $<11,200$ & $<11,200$ & $<11,200$ \\
\hline S98T000720 & $224: 10$ & Whole & $<9,820$ & $<9,760$ & $<9,790$ \\
\hline S97T002402 & \multirow[t]{2}{*}{$224: 11$} & Upper half & $<10,100$ & $<10,000$ & $<10,100$ \\
\hline S97T002397 & & Lower half & $<9840$ & $<9,620$ & $<9,730$ \\
\hline \multicolumn{2}{|l|}{ Minuids: } & (1:1: & 1.96110 & $.08 \mathrm{ng}$ & $108.81 \mathrm{~m}$ \\
\hline S97T002179 & 223:1 & Drainable liquid & $<300$ & $<300$ & $<300$ \\
\hline S97T002188 & $223: 2$ & Drainable liquid & $<300$ & $<300$ & $<300$ \\
\hline S97T002199 & $223: 3$ & Drainable liquid & $<300$ & $<300$ & $<300$ \\
\hline S97T002200 & $223: 4$ & Drainable liquid & $<300$ & $<300$ & $<300$ \\
\hline S97T002215 & $223: 5$ & Drainable liquid & $<300$ & $<300$ & $<300$ \\
\hline S97T002323 & $224: 1$ & Drainable liquid & $<300$ & $<300$ & $<300$ \\
\hline S97T002371 & $224: 3$ & Drainable liquid & $<300$ & $<300$ & $<300$ \\
\hline S97T002372 & $224: 5$ & Drainable liquid & $<300$ & $<300$ & $<300$ \\
\hline
\end{tabular}


Table B2-43. Tank 241-SX-106 Analytical Results: Vanadium (ICP). (2 sheets)

\begin{tabular}{|c|c|c|c|c|c|}
\hline Sormole & 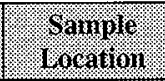 & 6rimule & Resull & Burlucato & Meran \\
\hline \multicolumn{2}{|c|}{ Solids: acid digest } & & $1,18 \mathrm{sg}$ & 149 & \% \\
\hline S98T000695 & $223: 6$ & Whole & $<20.1$ & $<18.8$ & $<19.5$ \\
\hline \$98T000705 & $223: 6 \dot{A}$ & Whole & $<18.7$ & $<19.6$ & $<19.1$ \\
\hline S98T000706 & $223: 9$ & Whole & $<19$ & $<18.8$ & $<18.9$ \\
\hline S98T000721 & $224: 2$ & Whole & $<12.1$ & $<8.76$ & $<10.4$ \\
\hline \$98T000722 & $224: 4$ & Whole & $<9.72$ & $<9.58$ & $<9.65$ \\
\hline S98T000723 & $224: 7$ & Whole & $<19.7$ & $<19.4$ & $<19.5$ \\
\hline S98T000724 & $224: 10$ & Whole & $<18$ & $<17.7$ & $<17.9$ \\
\hline \multicolumn{2}{|c|}{ Sollos fusing } & & 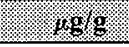 & 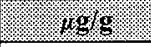 & 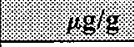 \\
\hline S97T002177 & $223: 1$ & Lower half & $<1,040$ & $<1,020$ & $<1,030$ \\
\hline S97T002185 & $223: 2$ & Lower half & $<958$ & $<946$ & $<952$ \\
\hline S97T002194 & $223: 3$ & Lower half & $<939$ & $<934$ & $<937$ \\
\hline S97T002204 & $223: 4$ & Lower half & $<1,100$ & $<1,070$ & $<1,090$ \\
\hline S97T002231 & $223: 5$ & Lower half & $<922$ & $<951$ & $<937$ \\
\hline$\$ 98 T 000694$ & $223: 6$ & Whole & $<965$ & $<946$ & $<956$ \\
\hline S98T000703 & $223: 6 \mathrm{~A}$ & Whole & $<926$ & $<943$ & $<935$ \\
\hline \$97T002233 & \multirow[t]{2}{*}{$223: 7$} & Upper half & $<1,050$ & $<1,000$ & $<1,030$ \\
\hline S97T002232 & & Lower half & $<979$ & $<1,010$ & $<995$ \\
\hline \$97T002235 & \multirow[t]{2}{*}{$223: 8$} & Upper half & $<1,010$ & $<1,010$ & $<1,010$ \\
\hline S97T002234 & & Lower half & $<992$ & $<1,000$ & $<996$ \\
\hline S98T000704 & $223: 9$ & Whole & $<1,010$ & $<1,020$ & $<1,020$ \\
\hline S97T002265 & \multirow[t]{2}{*}{$223: 10$} & Upper half & $<985$ & $<984$ & $<985$ \\
\hline S97T002263 & & Lower half & $<1,020$ & $<1,030$ & $<1,030$ \\
\hline S97T002320 & $224: 1$ & Lower half & $<950$ & $<923$ & $<937$ \\
\hline S98T000717 & $224: 2$ & Whole & $<1,010$ & $<976$ & $<993$ \\
\hline S97T002334 & $224: 3$ & Lower half & $<914$ & $<923$ & $<919$ \\
\hline S98T000718 & $224: 4$ & Whole & $<1,010$ & $<995$ & $<1,000$ \\
\hline S97T002360 & \multirow[t]{2}{*}{$224: 5$} & Upper half & $<999$ & $<1,020$ & $<1,010$ \\
\hline \$97T002359 & & Lower half & $<1,010$ & $<999$ & $<1,000$ \\
\hline \$97T002362 & \multirow[t]{2}{*}{$224: 6$} & Upper half & $<910$ & $<873$ & $<892$ \\
\hline S97T002361 & & Lower half & $<967$ & $<978$ & $<973$ \\
\hline
\end{tabular}


HNF-SD-WM-ER-645 Rev. 1

Table B2-43. Tank 241-SX-106 Analytical Results: Vanadium (ICP). (2 sheets)

\begin{tabular}{|c|c|c|c|c|c|}
\hline Sample & $\begin{array}{l}\text { Sample } \\
\text { Loration }\end{array}$ & $\begin{array}{l}\text { Sample } \\
\text { Portion. }\end{array}$ & Result & Buplieate & Vrean \\
\hline \multicolumn{3}{|c|}{ Solids: rusion (cont d) } & 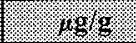 & $1.99 \mathrm{~g}:$ & 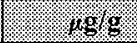 \\
\hline S98T000719 & $224: 7$ & Whole & $<967$ & $<999$ & $<983$ \\
\hline S97T002364 & \multirow[t]{2}{*}{$224: 8$} & Upper half & $<1,010$ & $<1,000$ & $<1,010$ \\
\hline S97T002363 & & Lower half & $<923$ & $<905$ & $<914$ \\
\hline S97T002392 & \multirow[t]{2}{*}{$224: 9$} & Upper half & $<1,090$ & $<1,100$ & $<1,100$ \\
\hline S97T002387 & & Lower half & $<1,120$ & $<1,120$ & $<1,120$ \\
\hline S98T000720 & $224: 10$ & Whole & $<982$ & $<976$ & $<979$ \\
\hline S97T002402 & \multirow[t]{2}{*}{$224: 11$} & Upper half & $<1,010$ & $<1,000$ & $<1,010$ \\
\hline S97T002397 & & Lower half & $<984$ & $<962$ & $<973$ \\
\hline \multicolumn{3}{|c|}{ Wiands : } & . .096171 & rgine & . 19.911 \\
\hline S97T002179 & $223: 1$ & Drainable liquid & $<30.1$ & $<30.1$ & $<30.1$ \\
\hline S97T002188 & $223: 2$ & Drainable liquid & $<30.1$ & $<30.1$ & $<30.1$ \\
\hline S97T002199 & $223: 3$ & Drainable liquid & $<30.1$ & $<30.1$ & $<30.1$ \\
\hline \$97T002200 & 223:4 & Drainable liquid & $<30.1$ & $<30.1$ & $<30.1$ \\
\hline S97T002215 & $223: 5$ & Drainable liquid & $<30.1$ & $<30.1$ & $<30.1$ \\
\hline S97T002323 & $224: 1$ & Drainable liquid & $<30.1$ & $<30.1$ & $<30.1$ \\
\hline \$97T002371 & $224: 3$ & Drainable liquid & $<30.1$ & $<30.1$ & $<30.1$ \\
\hline S97T002372 & $224: 5$ & Drainable liquid & $<30.1$ & $<30.1$ & $<30.1$ \\
\hline
\end{tabular}


Table B2-44. Tank 241-SX-106 Analytical Results: Zinc (ICP). (2 sheets)

\begin{tabular}{|c|c|c|c|c|c|}
\hline Sample. & 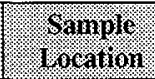 & W. & Resull & rivilueate & Yean \\
\hline \multicolumn{3}{|c|}{ 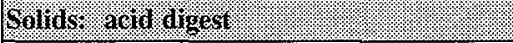 } & $149 \%$ & $6 \% 9$ & 1,2979 \\
\hline \$98T000695 & $223: 6$ & Whole & 22.2 & 20.1 & 21.1 \\
\hline \$98T000705 & $223: 6 \mathrm{~A}$ & Whole & 26.4 & 21 & $23.7^{\mathrm{QC}: \mathrm{c}}$ \\
\hline S98T000706 & 223:9 & Whole & 22.3 & 20.3 & 21.3 \\
\hline S98T000721 & $224: 2$ & Whole & 19 & 13.5 & $16.3^{\mathrm{QC:e}}$ \\
\hline S98T000722 & $224: 4$ & Whole & 15.8 & 14.8 & 15.3 \\
\hline S98T000723 & $224: 7$ & Whole & 20.1 & 20.1 & 20.1 \\
\hline \$98T000724 & $224: 10$ & Whole & 23.1 & 23 & 23.1 \\
\hline \multicolumn{2}{|c|}{ Solids? mision } & & 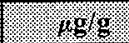 & 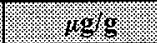 & 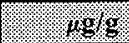 \\
\hline S97T002177 & $223: 1$ & Lower half & $<208$ & $<204$ & $<206$ \\
\hline \$97T002185 & $223: 2$ & Lower half & $<192$ & $<189$ & $<191$ \\
\hline S97T002194 & $223: 3$ & Lower half & $<188$ & $<187$ & $<188$ \\
\hline S97T002204 & $223: 4$ & Lower half & $<220$ & $<215$ & $<218$ \\
\hline S97T002231 & $223: 5$ & Lower half & $<184$ & $<190$ & $<187$ \\
\hline S98T000694 & $223: 6$ & Whole & $<193$ & $<189$ & $<191$ \\
\hline S98T000703 & $223: 6 \mathrm{~A}$ & Whole & $<185$ & $<189$ & $<187$ \\
\hline \$97T002233 & \multirow[t]{2}{*}{$223: 7$} & Upper half & $<210$ & $<200$ & $<205$ \\
\hline \$97T002232 & & Lower half & $<196$ & $<203$ & $<200$ \\
\hline S97T002235 & \multirow[t]{2}{*}{$223: 8$} & Upper half & $<203$ & $<202$ & $<203$ \\
\hline S97T002234 & & Lower half & $<198$ & $<201$ & $<200$ \\
\hline \$98T000704 & $223: 9$ & Whole & $<202$ & $<204$ & $<203$ \\
\hline S97T002265 & \multirow[t]{2}{*}{$223: 10$} & Upper half & $<197$ & $<197$ & $<197$ \\
\hline$\$ 97 T 002263$ & & Lower half & $<205$ & $<205$ & $<205$ \\
\hline S97T002320 & $224: 1$ & Lower half & $<190$ & $<185$ & $<188$ \\
\hline S98T000717 & $224: 2$ & Whole & $<202$ & $<195$ & $<199$ \\
\hline S97T002334 & $224: 3$ & Lower half & $<183$ & $<185$ & $<184$ \\
\hline \$98T000718 & $224: 4$ & Whole & $<201$ & $<199$ & $<200$ \\
\hline \$97T002360 & \multirow[t]{2}{*}{$224: 5$} & Upper half & $<200$ & $<204$ & $<202$ \\
\hline \$97T002359 & & Lower half & $<202$ & $<200$ & $<201$ \\
\hline S97T002362 & \multirow[t]{2}{*}{$224: 6$} & Upper half & $<182$ & $<175$ & $<179$ \\
\hline \$97T002361 & & Lower half & $<193$ & $<196$ & $<195$ \\
\hline
\end{tabular}


HNF-SD-WM-ER-645 Rev. 1

Table B2-44. Tank 241-SX-106 Analytical Results: Zinc (ICP). (2 sheets)

\begin{tabular}{|c|c|c|c|c|c|}
\hline $\begin{array}{l}\text { Samile } \\
\text { Nunber }\end{array}$ & Sample & $\begin{array}{l}\text { Sample. } \\
\text { eortion. }\end{array}$ & Resull & Dullicare. & Mean \\
\hline \multicolumn{3}{|c|}{ Solids: fision (Gontroly } & 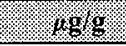 & (2) $19 \mathrm{gg} \mathrm{g}$. & 3.8 .989 \\
\hline S98T000719 & $224: 7$ & Whole & $<193$ & $<200$ & $<197$ \\
\hline S97T002364 & \multirow[t]{2}{*}{$224: 8$} & Upper half & $<202$ & 233 & $<218$ \\
\hline$\$ 97 T 002363$ & & Lower half & $<185$ & $<181$ & $<183$ \\
\hline S97T002392 & \multirow[t]{2}{*}{$224: 9$} & Upper half & $<219$ & $<219$ & $<219$ \\
\hline S97T002387 & & Lower half & $<223$ & $<224$ & $<224$ \\
\hline$\$ 98 \mathrm{~T} 000720$ & $224: 10$ & Whole & $<196$ & $<195$ & $<196$ \\
\hline S97T002402 & \multirow[t]{2}{*}{$224: 11$} & Upper half & $<201$ & $<201$ & $<201$ \\
\hline S97T002397 & & Lower half & $<197$ & $<192$ & $<195$ \\
\hline \multicolumn{2}{|l|}{ Minuids } & 4 & 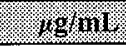 & $.4 \mathrm{~g} n \mathrm{nl}$ & $.199 \mathrm{~min}$ \\
\hline S97T002179 & $223: 1$ & Drainable liquid & $<6.01$ & $<6.01$ & $<6.01$ \\
\hline S97T002188 & $223: 2$ & Drainable liquid & $<6.01$ & $<6.01$ & $<6.01$ \\
\hline S97T002199 & $223: 3$ & Drainable liquid & $<6.01$ & $<6.01$ & $<6.01$ \\
\hline S97T002200 & $223: 4$ & Drainable liquid & $<6.01$ & $<6.01$ & $<6.01$ \\
\hline S97T002215 & $223: 5$ & Drainable liquid & $<6.01$ & $<6.01$ & $<6.01$ \\
\hline S97T002323 & $224: 1$ & Drainable liquid & $<6.01$ & $<6.01$ & $<6.01$ \\
\hline S97T002371 & $224: 3$ & Drainable liquid & $<6.01$ & $<6.01$ & $<6.01$ \\
\hline S97T002372 & $224: 5$ & Drainable liquid & $<6.01$ & $<6.01$ & $<6.01$ \\
\hline
\end{tabular}


Table B2-45. Tank 241-SX-106 Analytical Results: Zirconium (ICP). (2 sheets)

\begin{tabular}{|c|c|c|c|c|c|}
\hline Samisle & 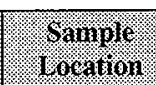 & 6ampre & Resuil & Groplusate & Men \\
\hline \multicolumn{2}{|c|}{ Sollits: acid digest } & & reg/9: & 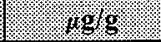 & . \\
\hline S98T000695 & $223: 6$ & Whole & 9.19 & 8.93 & 9.06 \\
\hline S98T000705 & $223: 6 \mathrm{~A}$ & Whole & 15.4 & 11.4 & $13.4^{\mathrm{QC}: \mathrm{e}}$ \\
\hline S98T000706 & $223: 9$ & Whole & 10.9 & 10.2 & 10.6 \\
\hline S98T000721 & $224: 2$ & Whole & $<2.42$ & $<1.75$ & $<2.08$ \\
\hline S98T000722 & $224: 4$ & Whole & $<1.94$ & $<1.92$ & $<1.93$ \\
\hline S98T000723 & $224: 7$ & Whole & 5.42 & 6.3 & 5.86 \\
\hline \$98T000724 & $224: 10$ & Whole & 25.7 & 23.9 & 24.8 \\
\hline \multicolumn{2}{|l|}{ Solinst - finsion. } & (1. & . 1098 & 129.9 & . $198 \mathrm{~g}$ \\
\hline S97T002177 & $223: 1$ & Lower half & $<208$ & $<204$ & $<206$ \\
\hline S97T002185 & $223: 2$ & Lower half & $<192$ & $<189$ & $<191$ \\
\hline S97T002194 & $223: 3$ & Lower half & $<188$ & $<187$ & $<188$ \\
\hline S97T002204 & $223: 4$ & Lower half & $<220$ & $<215$ & $<218$ \\
\hline \$97T002231 & $223: 5$ & Lower haif & $<184$ & $<190$ & $<187$ \\
\hline S98T000694 & $223: 6$ & Whole & $<193$ & $<189$ & $<191$ \\
\hline S98T000703 & $223: 6 \mathrm{~A}$ & Whole & $<185$ & $<189$ & $<187$ \\
\hline S97T002233 & \multirow[t]{2}{*}{$223: 7$} & Upper half & $<210$ & $<200$ & $<205$ \\
\hline S97T002232 & & Lower half & $<196$ & $<203$ & $<200$ \\
\hline S97T002235 & \multirow[t]{2}{*}{$223: 8$} & Upper half & $<203$ & $<202$ & $<203$ \\
\hline S97T002234 & & Lower half & $<198$ & $<201$ & $<200$ \\
\hline S98T000704 & $223: 9$ & Whole & $<202$ & $<204$ & $<203$ \\
\hline \$97T002265 & \multirow[t]{2}{*}{$223: 10$} & Upper half & $<197$ & $<197$ & $<197$ \\
\hline S97T002263 & & Lower half & $<205$ & $<205$ & $<205$ \\
\hline S97T002320 & $224: 1$ & Lower half & $<190$ & $<185$ & $<188$ \\
\hline S98T000717 & $224: 2$ & Whole & $<202$ & $<195$ & $<199$ \\
\hline S97T002334 & $224: 3$ & Lower half & $<183$ & $<185$ & $<184$ \\
\hline S98T000718 & $224: 4$ & Whole & $<201$ & $<199$ & $<200$ \\
\hline S97T002360 & \multirow[t]{2}{*}{$224: 5$} & Upper half & $<200$ & $<204$ & $<202$ \\
\hline S97T002359 & & Lower half & $<202$ & $<200$ & $<201$ \\
\hline S97T002362 & \multirow[t]{2}{*}{$224: 6$} & Upper half & $<182$ & $<175$ & $<179$ \\
\hline S97T002361 & & Lower half & $<193$ & $<196$ & $<195$ \\
\hline
\end{tabular}


Table B2-45. Tank 241-SX-106 Analytical Results: Zirconium (ICP). (2 sheets)

\begin{tabular}{|c|c|c|c|c|c|}
\hline Sample: & $\begin{array}{l}\text { Sample } \\
\text { Location }\end{array}$ & $\begin{array}{l}\text { Sample } \\
\text { Portion }\end{array}$ & Result & Buplieate & Mean \\
\hline \multicolumn{2}{|c|}{ Solins fusion (cont d) } & $1: 2$ & 1628 & .1098 & 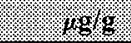 \\
\hline S98T000719 & $224: 7$ & Whole & $<193$ & $<200$ & $<197$ \\
\hline S97T002364 & \multirow[t]{2}{*}{$224: 8$} & Upper half & $<202$ & $<201$ & $<202$ \\
\hline S97T002363 & & Lower half & $<185$ & $<181$ & $<183$ \\
\hline S97T002392 & \multirow[t]{2}{*}{$224: 9$} & Upper half & $<219$ & $<219$ & $<219$ \\
\hline S97T002387 & & Lower half & $<223$ & $<224$ & $<224$ \\
\hline S98T000720 & $224: 10$ & Whole & $<196$ & $<195$ & $<196$ \\
\hline S97T002402 & \multirow[t]{2}{*}{$224: 11$} & Upper half & $<201$ & $<201$ & $<201$ \\
\hline S97.T002397 & & Lower half & $<197$ & $<192$ & $<195$ \\
\hline \multicolumn{2}{|l|}{ Eiguitis: } & 2 & 1.967910 & $1491 \mathrm{mi}$ & . $19 \mathrm{~g} / \mathrm{ml}$ \\
\hline S97T002179 & 223:1 & Drainable liquid & $<6.01$ & $<6.01$ & $<6.01$ \\
\hline S97T002188 & $223: 2$ & Drainable liquid & $<6.01$ & $<6.01$ & $<6.01$ \\
\hline S97T002199 & $223: 3$ & Drainable liquid & $<6.01$ & $<6.01$ & $<6.01$ \\
\hline S97T002200 & $223: 4$ & Drainable liquid & $<6.01$ & $<6.01$ & $<6.01$ \\
\hline S97T002215 & $223: 5$ & Drainable liquid & $<6.01$ & $<6.01$ & $<6.01$ \\
\hline S97T002323 & $224: 1$ & Drainable liquid & $<6.01$ & $<6.01$ & $<6.01$ \\
\hline S97T002371 & $224: 3$ & Drainable liquid & $<6.01$ & $<6.01$ & $<6.01$ \\
\hline S97T002372 & $224: 5$ & Drainable liquid & $<6.01$ & $<6.01$ & $<6.01$ \\
\hline
\end{tabular}


Table B2-46. Tank 241-SX-106 Analytical Results: Bromide (IC). (2 sheets)

\begin{tabular}{|c|c|c|c|c|c|}
\hline samilo & 6. & Sample & Resulu & orourate & yen \\
\hline \multicolumn{2}{|c|}{ 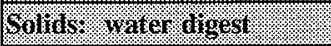 } & & 6989 & 1,961 & 1.1898 \\
\hline S97T002178 & $223: 1$ & Lower half & $<962$ & $<973$ & $<967$ \\
\hline S97T002186 & $223: 2$ & Lower half & $<941$ & $<897$ & $<919$ \\
\hline S97T002196 & $223: 3$ & Lower half & $<1,150$ & $<1,160$ & $<1,150$ \\
\hline S97T002205 & $223: 4$ & Lower half & 1,160 & 1,240 & 1,200 \\
\hline S97T002237 & $223: 5$ & Lower half & $<1,040$ & $<983$ & $<1,010$ \\
\hline S98T000696 & $223: 6$ & Whole & $<950$ & $<937$ & $<944$ \\
\hline \$98T000707 & $223: 6 \mathrm{~A}$ & Whole & 574 & 558 & 566 \\
\hline S97T002239 & \multirow[t]{2}{*}{$223: 7$} & Upper half & 2,790 & 2,660 & 2,730 \\
\hline S97T002238 & & Lower half & $<1,010$ & $<1,000$ & $<1,000$ \\
\hline S97T002241 & \multirow[t]{2}{*}{$223: 8$} & Upper half & 1,820 & 1,730 & 1,780 \\
\hline S97T002240 & & Lower half & $<1,000$ & $<987$ & $<994$ \\
\hline S98T000708 & $223: 9$ & Whole & $2.14 \mathrm{E}+05$ & $2.15 \mathrm{E}+05$ & $2.14 \mathrm{E}+05$ \\
\hline S97T002266 & \multirow[t]{2}{*}{$223: 10$} & Upper half & 2,630 & 2,590 & 2,610 \\
\hline$\$ 97 T 002264$ & & Lower half & 2,820 & 2,780 & 2,800 \\
\hline S97T002321 & $224: 1$ & Lower half & $<944$ & $<1,020$ & $<982$ \\
\hline S98T000725 & $224: 2$ & Whole & $<505$ & $<506$ & $<505$ \\
\hline S97T002335 & $224: 3$ & Lower half & $<957$ & $<959$ & $<958$ \\
\hline \$98T000726 & $224: 4$ & Whole & $<507$ & $<516$ & $<511$ \\
\hline S97T002354 & \multirow[t]{2}{*}{$224: 5$} & Upper half & $<1,020$ & $<1,020$ & $<1,020$ \\
\hline \$97T002353 & & Lower half & $<1,000$ & $<957$ & $<980$ \\
\hline \$97T002356 & \multirow[t]{2}{*}{$224: 6$} & Upper half & $<848$ & $<767$ & $<807$ \\
\hline \$97T002355 & & Lower half & $<988$ & $<1,020$ & $<1,000$ \\
\hline S98T000727 & $224: 7$ & Whole & $<948$ & $<900$ & $<924$ \\
\hline S97T002358 & \multirow[t]{2}{*}{$224: 8$} & Upper half & 1,970 & 1,910 & 1,940 \\
\hline S97T002357 & & Lower half & $<967$ & $<953$ & $<960$ \\
\hline \$97T002393 & \multirow[t]{2}{*}{$224: 9$} & Upper half & 1,330 & 1,360 & 1,340 \\
\hline S97T002388 & & Lower half & 2,510 & $<2,340$ & $<2,430$ \\
\hline S98T000728 & $224: 10$ & Whole & $<973$ & $<985$ & $<979$ \\
\hline S97T002403 & \multirow[t]{2}{*}{$224: 11$} & Upper half & 1,080 & 1,040 & 1,060 \\
\hline \$97T002398 & & Lower half & 1,040 & 997 & 1,020 \\
\hline
\end{tabular}


Table B2-46. Tank 241-SX-106 Analytical Results: Bromide (IC). (2 sheets)

\begin{tabular}{|c|c|c|c|c|c|}
\hline Sample: & $\begin{array}{l}\text { Sumples } \\
\text { Incation }\end{array}$ & $\begin{array}{l}\text { Sample } \\
\text { Portion }\end{array}$ & Resulf & ouplieare & Men \\
\hline Miruids : & $4: 3.8$. & (:-3: & $14 \mathrm{gmin}$ & $=1.9 / \mathrm{mi}$ & $1.96 \mathrm{nl}$ \\
\hline S97T002179 & $223: 1$ & Drainable liquid & $<644$ & $<644$ & $<644$ \\
\hline S97T002188 & $223: 2$ & Drainable liquid & 764 & 756 & 760 \\
\hline \$97T002199 & $223: 3$ & Drainable liquid & 719 & 740 & 729 \\
\hline S97T002200 & $223: 4$ & Drainable liquid & 1,380 & 1,360 & 1,370 \\
\hline S97T002215 & $223: 5$ & Drainable liquid & $<1,280$ & 1,330 & $<1,300$ \\
\hline S97T002323 & $224: 1$ & Drainable liquid & $<1,280$ & $<1,280$ & $<1,280$ \\
\hline S97T002371 & $224: 3$ & Drainable liquid & 1,360 & 1,320 & 1,340 \\
\hline S97T002372 & $224: 5$ & Drainable liquid & 846 & 779 & 812 \\
\hline
\end{tabular}


Table B2-47. Tank 241-SX-106 Analytical Results: Chloride (IC). (2 sheets)

\begin{tabular}{|c|c|c|c|c|c|}
\hline $\begin{array}{l}\text { Sample: } \\
\text { Nuniber }\end{array}$ & $\begin{array}{l}\text { Sample } \\
\text { I }\end{array}$ & $\begin{array}{l}\text { Sample } \\
\text { Portion }\end{array}$ & resulu & grupivare & Mon \\
\hline Solings yater & dingest & & 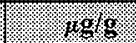 & 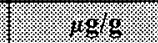 & 4. \\
\hline S97T002178 & $223: 1$ & Lower half & 2,990 & 2,870 & 2,930 \\
\hline S97T002186 & $223: 2$ & Lower half & 6,620 & 6,740 & 6,680 \\
\hline S97T002196 & $223: 3$ & Lower half & 3,470 & 3,430 & 3,450 \\
\hline S97T002205 & $223: 4$ & Lower half & 2,770 & 3,080 & 2,930 \\
\hline S97T002237 & $223: 5$ & Lower half & 7,000 & 6,600 & 6,800 \\
\hline S98T000696 & $223: 6$ & Whole & 4,050 & 3,570 & 3,810 \\
\hline S98T000707 & $223: 6 \mathrm{~A}$ & Whole & 3,910 & 3,660 & 3,780 \\
\hline S97T002239 & \multirow[t]{2}{*}{$223: 7$} & Upper half & 7,210 & 6,890 & 7,050 \\
\hline S97T002238 & & Lower half & 6,140 & 6,000 & 6,070 \\
\hline S97T002241 & \multirow[t]{2}{*}{$223: 8$} & Upper half & 7,840 & 7,340 & 7,590 \\
\hline S97T002240 & & Lower half & 5,260 & 5,170 & 5,210 \\
\hline S98T000708 & $223: 9$ & Whole & 2,870 & 2,850 & 2,860 \\
\hline S97T002266 & \multirow[t]{2}{*}{$223: 10$} & Upper half & 11,900 & 12,300 & 12,100 \\
\hline S97T002264 & & Lower half & 13,900 & 14,000 & 13,900 \\
\hline S97T002321 & $224: 1$ & Lower half & 6,960 & 7,600 & 7,280 \\
\hline S98T000725 & $224: 2$ & Whole & 3,750 & 4,480 & 4,120 \\
\hline S97T002335 & $224: 3$ & Lower half & 7,950 & 7,220 & 7,580 \\
\hline S98T000726 & $224: 4$ & Whole & 4,820 & 4,170 & 4,490 \\
\hline S97T002354 & \multirow[t]{2}{*}{$224: 5$} & Upper half & 6,690 & 6,160 & 6,430 \\
\hline S97T002353 & & Lower half & 7,060 & 7,090 & 7,070 \\
\hline S97T002356 & \multirow[t]{2}{*}{$224: 6$} & Upper half & 7,610 & 8,120 & 7,870 \\
\hline S97T002355 & & Lower half & 7,910 & 8,900 & 8,410 \\
\hline S98T000727 & $224: 7$ & Whole & 3,330 & 3,150 & 3,240 \\
\hline S97T002358 & \multirow[t]{2}{*}{$224: 8$} & Upper half & 6,170 & 5,240 & 5,700 \\
\hline S97T002357 & & Lower half & 6,150 & 6,640 & 6,390 \\
\hline S97T002393 & \multirow[t]{2}{*}{$224: 9$} & Upper half & 4,490 & 4,960 & 4,720 \\
\hline S97T002388 & & Lower half & 5,490 & 5,430 & 5,460 \\
\hline S98T000728 & $224: 10$ & Whole & 3,070 & 3,140 & 3,100 \\
\hline S97T002403 & \multirow[t]{2}{*}{$224: 11$} & Upper half & 9,330 & 9,940 & 9,640 \\
\hline S97T002398 & & Lower half & 5,070 & 5,020 & 5,050 \\
\hline
\end{tabular}


Table B2-47. Tank 241-SX-106 Analytical Results: Chloride (IC). (2 sheets)

\begin{tabular}{|c|c|c|c|c|c|}
\hline $\begin{array}{l}\text { Sample } \\
\text { Number: }\end{array}$ & S Samplo & $\begin{array}{l}\text { Saruple } \\
\text { Portion }\end{array}$ & resing & Buplicato. & Mean \\
\hline Mguids: & ?. & 莎: & . & (1. & 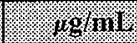 \\
\hline S97T002179 & $223: 1$ & Drainable liquid & 12,000 & 12,000 & 12,000 \\
\hline S97T002188 & $223: 2$ & Drainable liquid & 11,500 & 11,500 & 11,500 \\
\hline S97T002199 & 223:3 & Drainable liquid & 11,400 & 11,400 & 11,400 \\
\hline S97T002200 & $223: 4$ & Drainable liquid & 11,400 & 11,300 & 11,400 \\
\hline S97T002215 & $223: 5^{\circ}$ & Drainable liquid & 12,300 & 13,000 & 12,700 \\
\hline S97T002323 & $224: 1$ & Drainable liquid & 12,200 & 12,500 & 12,300 \\
\hline S97T002371 & $224: 3$ & Drainable liquid & 11,000 & 11,100 & 11,100 \\
\hline S97T002372 & $224: 5$ & Drainable liquid & 11,700 & 11,500 & 11,600 \\
\hline
\end{tabular}


Table B2-48. Tank 241-SX-106 Analytical Results: Fluoride (IC). (2 sheets)

\begin{tabular}{|c|c|c|c|c|c|}
\hline $\begin{array}{l}\text { Sample } \\
\text { Numuer }\end{array}$ & Sample & $\begin{array}{l}\text { Sample } \\
\text { erorion }\end{array}$ & Resill & Bullicate & Merin \\
\hline \multicolumn{2}{|c|}{ 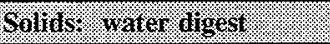 } & : & $1.10 \mathrm{gg}$ & $4.19 \mathrm{gg} g$. & 1,898 \\
\hline S97T002178 & $223: 1$ & Lower half & $<92.3$ & $<93.4$ & $<92.9$ \\
\hline S97T002186 & $223: 2$ & Lower half & $<90.4$ & $<86.1$ & $<88.2$ \\
\hline S97T002196 & $223: 3$ & Lower half & $<110$ & $<111$ & $<111$ \\
\hline S97T002205 & $223: 4$ & Lower half & $<110$ & $<117$ & $<113$ \\
\hline \$97T002237 & $223: 5$ & Lower half & 404 & 422 & 413 \\
\hline S98T000696 & $223: 6$ & Whole & 227 & 186 & 207 \\
\hline S98T000707 & $223: 6 \mathrm{~A}$ & Whole & 174 & 170 & 172 \\
\hline S97T002239 & \multirow[t]{2}{*}{$223: 7$} & Upper half & 675 & 639 & 657 \\
\hline S97T002238 & & Lower half & 483 & 600 & $542^{\mathrm{QC}: \mathrm{e}}$ \\
\hline S97T002241 & \multirow[t]{2}{*}{$223: 8$} & Upper half & 283 & 274 & 279 \\
\hline \$97T002240 & & Lower half & 217 & 188 & $202^{\mathrm{QC}: \mathrm{c}}$ \\
\hline S98T000708 & $223: 9$ & Whole & 135 & 144 & 140 \\
\hline S97T002266 & \multirow[t]{2}{*}{$223: 10$} & Upper half & 641 & 488 & $564^{\mathrm{QC}: c, \mathrm{e}}$ \\
\hline S97T002264 & & Lower half & 551 & 505 & $528^{\mathrm{QC}: \mathrm{c}}$ \\
\hline S97T002321 & $224: 1$ & Lower half & 399 & 412 & $405^{\mathrm{QC}: c}$ \\
\hline S98T000725 & $224: 2$ & Whole. & 216 & 224 & 220 \\
\hline S97T002335 & $224: 3$ & Lower half & 404 & 386 & 395 \\
\hline S98T000726 & $224: 4$ & Whole & 233 & 225 & 229 \\
\hline S97T002354 & \multirow[t]{2}{*}{$224: 5$} & Upper half & 377 & 350 & 364 \\
\hline S97T002353 & & Lower half & 741 & 572 & $657^{\mathrm{QC}: \mathrm{e}}$ \\
\hline S97T002356 & \multirow[t]{2}{*}{$224: 6$} & Upper half & $<81.4$ & $<73.6$ & $<77.5$ \\
\hline S97T002355 & & Lower half & 397 & 408 & 402 \\
\hline S98T000727 & $224: 7$ & Whole & 269 & 237 & 253 \\
\hline S97T002358 & \multirow[t]{2}{*}{$224: 8$} & Upper half & 610 & 595 & 602 \\
\hline S97T002357 & & Lower half & 574 & 721 & $647^{\mathrm{QC}: e}$ \\
\hline S97T002393 & \multirow[t]{2}{*}{$224: 9$} & Upper half & 359 & 358 & 359 \\
\hline \$97T002388 & & Lower half & 1,400 & 1,540 & 1,470 \\
\hline S98T000728 & $224: 10$ & Whole & 261 & 266 & 264 \\
\hline S97T002403 & \multirow[t]{2}{*}{$224: 11$} & Upper half & 1,380 & 1,500 & 1,440 \\
\hline S97T002398 & & Lower half & 2,580 & 2,770 & 2,670 \\
\hline
\end{tabular}


HNF-SD-WM-ER-645 Rev. 1

Table B2-48. Tank 241-SX-106 Analytical Results: Fluoride (IC). (2 sheets)

\begin{tabular}{|c|c|c|c|c|c|}
\hline $\begin{array}{l}\text { Sample. } \\
\text { Nuniner. }\end{array}$ & $\begin{array}{l}\text { Samule } \\
\text { Inocanon }\end{array}$ & $\begin{array}{l}\text { Sample } \\
\text { Portion }\end{array}$ & Result & Bunlicate & Mrean \\
\hline Higuds. & 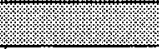 & U: & 4.9601 & $1.8 \mathrm{~g} / \mathrm{nI}$ & (ygral \\
\hline S97T002179 & $223: 1$ & Drainable liquid & $<61.8$ & $<61.8$ & $<61.8$ \\
\hline S97T002188 & $223: 2$ & Drainable liquid & $<61.8$ & $<61.8$ & $<61.8$ \\
\hline S97T002199 & $223: 3$ & Drainable liquid & 546 & 535 & 540 \\
\hline$\$ 97 T 002200$ & $223: 4$ & Drainable liquid & $<61.8$ & $<61.8$ & $<61.8$ \\
\hline S97T002215 & $223: 5$ & Drainable liquid & 572 & 598 & 585 \\
\hline S97T002323 & 224:1 & Drainable liquid & 408 & 426 & 417 \\
\hline S97T002371 & $224: 3$ & Drainable liquid & 409 & $<122$ & $<265^{\mathrm{QC:e}}$ \\
\hline S97T002372 & $224: 5$ & Drainable liquid & 496 & 497 & 496 \\
\hline
\end{tabular}


Table B2-49. Tank 241-SX-106 Analytical Results: Nitrate (IC). (2 sheets)

\begin{tabular}{|c|c|c|c|c|c|}
\hline Saminge & Gocatiou & 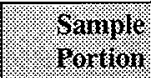 & Resiul & Bunirate & Whar \\
\hline Solins: wate & dygest & & 1790 & 600 & wo \\
\hline S97T002178 & 223:1 & Lower half & $4.72 \mathrm{E}+05$ & $5.15 \mathrm{E}+05$ & $4.93 E+05^{\mathrm{Qc}: \mathrm{d}}$ \\
\hline S97T002186 & $223: 2$ & Lower half & $1.36 \mathrm{E}+05$ & $1.43 \mathrm{E}+05$ & $1.40 \mathrm{E}+05$ \\
\hline S97T002196 & $223: 3$ & Lower half & $4.46 \mathrm{E}+05$ & $4.54 \mathrm{E}+05$ & $4.50 \mathrm{E}+05$ \\
\hline S97T002205 & $223: 4$ & Lower half & $4.02 E+05$ & $3.93 E+05$ & $3.98 \mathrm{E}+05$ \\
\hline S97T002237 & $223: 5$ & Lower half & $1.51 E+05$ & $1.56 \mathrm{E}+05$ & $1.53 \mathrm{E}+05$ \\
\hline \$98T000696 & $223: 6$ & Whole & 75,100 & 62,700 & 68,900 \\
\hline S98T000707 & $223: 6 \mathrm{~A}$ & Whole & 82,800 & 76,300 & 79,600 \\
\hline \$97T002239 & \multirow[t]{2}{*}{$223: 7$} & Upper half & $1.08 \mathrm{E}+05$ & $1.06 \mathrm{E}+05$ & $1.07 \mathrm{E}+05$ \\
\hline \$97T002238 & & Lower half & $2.63 \mathrm{E}+05$ & $2.46 \mathrm{E}+05$ & $2.55 \mathrm{E}+05$ \\
\hline \$97T002241 & \multirow[t]{2}{*}{$223: 8$} & Upper half & $1.52 \mathrm{E}+05$ & $1.54 \mathrm{E}+05$ & $1.53 \mathrm{E}+05$ \\
\hline \$97T002240 & & Lower half & $3.94 \mathrm{E}+05$ & $3.57 \mathrm{E}+05$ & $3.76 \mathrm{E}+05^{\mathrm{QC}: \mathrm{c}}$ \\
\hline S98T000708 & $223: 9$ & Whole & $<517$ & $<510$ & $<513$ \\
\hline \$97T002266 & \multirow[t]{2}{*}{$223: 10$} & Upper half & $9.59 \mathrm{E}+05$ & $9.51 \mathrm{E}+05$ & $9.55 \mathrm{E}+05^{\mathrm{QC}: \mathrm{c}}$ \\
\hline S97T002264 & & Lower half & $7.91 \mathrm{E}+05$ & $6.72 \mathrm{E}+05$ & $7.31 \mathrm{E}+05$ \\
\hline \$97T002321 & $224: 1$ & Lower half & $1.82 \mathrm{E}+05$ & $1.49 \mathrm{E}+05$ & $1.65 \mathrm{E}+05$ \\
\hline S98T000725 & $224: 2$ & Whole & 88000 & 98600 & $93300^{\mathrm{QC}: \mathrm{d}}$ \\
\hline \$97T002335 & $224: 3$ & Lower half & $1.85 \mathrm{E}+05$ & $2.06 \mathrm{E}+05$ & $1.95 \mathrm{E}+05$ \\
\hline S98T000726 & $224: 4$ & Whole & $1.03 \mathrm{E}+05$ & 93,200 & 98,100 \\
\hline \$97T002354 & \multirow[t]{2}{*}{$224: 5$} & Upper half & $1.75 E+05$ & $2.36 \mathrm{E}+05$ & $2.05 \mathrm{E}+05^{\mathrm{QC}: \mathrm{e}}$ \\
\hline \$97T002353 & & Lower half & $1.12 \mathrm{E}+05$ & $1.09 \mathrm{E}+05$ & $1.10 \mathrm{E}+05$ \\
\hline S97T002356 & \multirow[t]{2}{*}{$224: 6$} & Upper half & 97,400 & $1.01 \mathrm{E}+05$ & 99,200 \\
\hline S97T002355 & & Lower half & 94,000 & 94,900 & 94,500 \\
\hline S98T000727 & $224: 7$ & Whole & $1.21 \mathrm{E}+05$ & $1.20 \mathrm{E}+05$ & $1.21 \mathrm{E}+05$ \\
\hline S97T002358 & \multirow[t]{2}{*}{$224: 8$} & Upper half & $2.28 \mathrm{E}+05$ & $2.71 E+05$ & $2.50 \mathrm{E}+05$ \\
\hline \$97T002357 & & Lower half & $2.96 \mathrm{E}+05$ & $2.82 \mathrm{E}+05$ & $2.89 E+05$ \\
\hline \$97T002393 & \multirow[t]{2}{*}{$224: 9$} & Upper half & 4. $12 \mathrm{E}+05$ & $3.90 E+05$ & $4.01 E+05$ \\
\hline S97T002388 & & Lower half & $2.97 \mathrm{E}+05$ & $3.01 E+05$ & $2.99 E+05$ \\
\hline S98T000728 & $224: 10$ & Whole & $1.45 \mathrm{E}+05$ & $1.46 \mathrm{E}+05$ & $1.45 \mathrm{E}+05$ \\
\hline S97T002403 & \multirow[t]{2}{*}{$224: 11$} & Upper half & 81,100 & 80,800 & 81,000 \\
\hline S97T002398 & & Lower half & $2.47 \mathrm{E}+05$ & $2.80 E+05$ & $2.63 E+05$ \\
\hline
\end{tabular}


Table B2-49. Tank 241-SX-106 Analytical Results: Nitrate (IC). (2 sheets)

\begin{tabular}{|c|c|c|c|c|c|}
\hline $\begin{array}{l}\text { Sarnjle: } \\
\text { Number. }\end{array}$ & $\begin{array}{l}\text { Sample } \\
\text { I socition }\end{array}$ & $\begin{array}{l}\text { Sarmple } \\
\text { Portion }\end{array}$ & Result & Pinlinate & Mern \\
\hline Miquils "W & 4.3. & 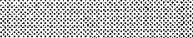 & (1) & mgm & (1) \\
\hline S97T002179 & $223: 1$ & Drainable liquid & $2.18 \mathrm{E}+05$ & $2.21 \mathrm{E}+05$ & $2.20 \mathrm{E}+05$ \\
\hline S97T002188 & $223: 2$ & Drainable liquid & $2.21 \mathrm{E}+05$ & $2.22 \mathrm{E}+05$ & $2.21 \mathrm{E}+05$ \\
\hline S97T002199 & $223: 3$ & Drainable liquid & $1.98 \mathrm{E}+05$ & $2.01 \mathrm{E}+05$ & $2.00 \mathrm{E}+05$ \\
\hline S97T002200 & $223: 4$ & Drainable liquid & $2.26 \mathrm{E}+05$ & $2.26 \mathrm{E}+05$ & $2.26 \mathrm{E}+05$ \\
\hline S97T002215 & $223: 5$ & Drainable liquid & $2.31 \mathrm{E}+05$ & $2.32 \mathrm{E}+05$ & $2.31 \mathrm{E}+05$ \\
\hline S97T002323 & $224: 1$ & Drainable liquid & $1.98 \mathrm{E}+05$ & $2.03 \mathrm{E}+05$ & $2.00 \mathrm{E}+05$ \\
\hline S97T002371 & $224: 3$ & Drainable liquid & $1.79 \mathrm{E}+05$ & $1.85 \mathrm{E}+05$ & $1.82 \mathrm{E}+05$ \\
\hline S97T002372 & $224: 5$ & Drainable liquid & $1.98 \mathrm{E}+05$ & $1.96 \mathrm{E}+05$ & $1.97 \mathrm{E}+05$ \\
\hline
\end{tabular}


HNF-SD-WM-ER-645 Rev. 1

Table B2-50. Tank 241-SX-106 Analytical Results: Nitrite (IC). (2 sheets)

\begin{tabular}{|c|c|c|c|c|c|}
\hline Sample & \%ockolo & Somprome & Resull: & Oriplicate & Mern \\
\hline \multicolumn{2}{|c|}{ Sollis. water dingest: } & 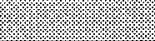 & 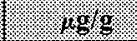 & 49.19.9. & 148 \\
\hline S97T002178 & $223: 1$ & Lower half & 33,600 & 32,400 & 33,000 \\
\hline S97T002186 & $223: 2$ & Lower half & 77,900 & 80,400 & 79,100 \\
\hline S97T002196 & $223: 3$ & Lower half & 40,500 & 39,200 & 39,800 \\
\hline S97T002205 & $223: 4$ & Lower half & 31,400 & 35,200 & 33,300 \\
\hline S97T002237 & $223: 5$ & Lower half & 75,100 & 73,900 & 74,500 \\
\hline S98T000696 & $223: 6$ & Whole & 43,500 & 38,200 & 40,800 \\
\hline S98T000707 & $223: 6 \mathrm{~A}$ & Whole & 42,200 & 40,500 & 41,400 \\
\hline S97T002239 & \multirow[t]{2}{*}{$223: 7$} & Upper half & 78,500 & 74,400 & 76,400 \\
\hline S97T002238 & & Lower half & 68,400 & 66,100 & 67,300 \\
\hline S97T002241 & \multirow[t]{2}{*}{$223: 8$} & Upper half & 85,300 & 81,000 & 83,100 \\
\hline S97T002240 & & Lower half & 57,800 & 57,200 & 57,500 \\
\hline S98T000708 & $223: 9$ & Whole & 30,300 & 31,000 & 30,600 \\
\hline S97T002266 & \multirow[t]{2}{*}{$223: 10$} & Upper half & $1.42 \mathrm{E}+05$ & $1.45 \mathrm{E}+05$ & $1.43 \mathrm{E}+05$ \\
\hline S97T002264 & & Lower half & $1.60 \mathrm{E}+05$ & $1.59 \mathrm{E}+05$ & $1.60 \mathrm{E}+05$ \\
\hline S97T002321 & $224: 1$ & Lower half & 73,100 & 78,900 & 76,000 \\
\hline S98T000725 & $224: 2$ & Whole & 43,300 & 50,800 & $47,000^{\mathrm{eC:d}}$ \\
\hline S97T002335 & $224: 3$ & Lower half & 82,600 & 76,300 & 79,500 \\
\hline \$98T000726 & $224: 4$ & Whole & 53,500 & 47,100 & 50,300 \\
\hline S97T002354 & \multirow[t]{2}{*}{$224: 5$} & Upper half & 73,200 & 68,300 & 70,700 \\
\hline S97T002353 & & Lower half & 74,700 & 77,100 & 75,900 \\
\hline S97T002356 & \multirow[t]{2}{*}{$224: 6$} & Upper half & 88,300 & 92,200 & 90,300 \\
\hline S97T002355 & & Lower half & 83,700 & 93,100 & 88,400 \\
\hline \$98T000727 & $224: 7$ & Whole & 35,600 & 35,000 & 35,300 \\
\hline S97T002358 & \multirow[t]{2}{*}{$224: 8$} & Upper half & 73,200 & 61,200 & 67,200 \\
\hline S97T002357 & & Lower half & 68,100 & 71,000 & 69,600 \\
\hline \$97T002393 & \multirow{2}{*}{ 224:9 } & Upper half & 50,500 & 53,400 & 51,900 \\
\hline S97T002388 & & Lower half & 58,800 & 55,400 & 57,100 \\
\hline S98T000728 & $224: 10$ & Whole & 36,600 & 38,200 & 37,400 \\
\hline S97T002403 & \multirow[t]{2}{*}{$224: 11$} & Upper half & 89,100 & 92,700 & 90,900 \\
\hline S97T002398 & & Lower half & 58,300 & 59,400 & 58,800 \\
\hline
\end{tabular}


Table B2-50. Tank 241-SX-106 Analytical Results: Nitrite (IC). (2 sheets)

\begin{tabular}{|c|c|c|c|c|c|}
\hline $\begin{array}{l}\text { Sample } \\
\text { Number }\end{array}$ & $\begin{array}{l}\text { Sample } \\
\text { I coeation }\end{array}$ & $\begin{array}{l}\text { Sample } \\
\text { Pontion }\end{array}$ & Resuil: & Burpinate & Mean \\
\hline Fiquits: & 4 & (1: (- & 1.9 .101 & $.4 \mathrm{~g} / \mathrm{nl}$ & $89 \mathrm{ginl}$ \\
\hline S97T002179 & $223: 1$ & Drainable liquid & $1.40 \mathrm{E}+05$ & $1.42 \mathrm{E}+05$ & $1.41 \mathrm{E}+05$ \\
\hline S97T002188 & $223: 2$ & Drainable liquid & $1.36 \mathrm{E}+05$ & $1.36 \mathrm{E}+05$ & $1.36 \mathrm{E}+05$ \\
\hline S97T002199 & $223: 3$ & Drainable liquid & $1.28 \mathrm{E}+05$ & $1.28 \mathrm{E}+05$ & $1.28 \mathrm{E}+05$ \\
\hline S97T002200 & $223: 4$ & Drainable liquid & $1.32 \mathrm{E}+05$ & $1.33 \mathrm{E}+05$ & $1.33 \mathrm{E}+05$ \\
\hline S97T002215 & $223: 5$ & Drainable liquid & $1.35 \mathrm{E}+05$ & $1.41 \mathrm{E}+05$ & $1.38 \mathrm{E}+05$ \\
\hline S97T002323 & $224: 1$ & Drainable liquid & $1.27 \mathrm{E}+05$ & $1.34 \mathrm{E}+05$ & $1.31 \mathrm{E}+05$ \\
\hline S97T002371 & $224: 3$ & Drainable liquid & $1.21 \mathrm{E}+05$ & $1.19 \mathrm{E}+05$ & $1.20 \mathrm{E}+05$ \\
\hline S97T002372 & $224: 5$ & Drainable liquid & $1.30 \mathrm{E}+05$ & $1.30 \mathrm{E}+05$ & $1.30 \mathrm{E}+05$ \\
\hline
\end{tabular}


HNF-SD-WM-ER-645 Rev. 1

Table B2-51. Tank 241-SX-106 Analytical Results: Phosphate (IC). (2 sheets)

\begin{tabular}{|c|c|c|c|c|c|}
\hline Sample & $\begin{array}{l}\text { Samplo } \\
\text { Location }\end{array}$ & $\begin{array}{l}\text { Sample } \\
\text { Tortion }\end{array}$ & Mesult & Brulivare & Mean \\
\hline \multicolumn{2}{|c|}{ Solids: water angest } & (x): & $1 \% 96$ & $.179 \%$ & 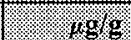 \\
\hline S97T002178 & $223: 1$ & Lower half & 9,300 & 9,890 & 9,590 \\
\hline S97T002186 & $223: 2$ & Lower half & 16,800 & 19,000 & 17,900 \\
\hline S97T002196 & $223: 3$ & Lower half & 10,300 & 9,810 & 10,100 \\
\hline S97T002205 & $223: 4$ & Lower half & 35,200 & 27,500 & $31,400^{\text {QC:e }}$ \\
\hline S97T002237 & $223: 5$ & Lower half & 18,700 & 13,300 & $16,000^{\mathrm{QC:e}}$ \\
\hline S98T000696 & $223: 6$ & Whole & 4,240 & 4,040 & 4,140 \\
\hline S98T000707 & $223: 6 \mathrm{~A}$ & Whole & 4,240 & 3,840 & 4,040 \\
\hline S97T002239 & \multirow[t]{2}{*}{$223: 7$} & Upper half & 13,000 & 10,900 & 11,900 \\
\hline S97T002238 & & Lower half & 9,290 & 10,900 & 10,100 \\
\hline S97T002241 & \multirow[t]{2}{*}{$223: 8$} & Upper half & 5,870 & 5,410 & 5,640 \\
\hline S97T002240 & & Lower half & 5,030 & 4,230 & 4,630 \\
\hline S98T000708 & $223: 9$ & Whole & 2,390 & 2,440 & 2,420 \\
\hline S97T002266 & \multirow[t]{2}{*}{$223: 10$} & Upper half & 17,300 & 15,600 & 16,500 \\
\hline S97T002264 & & Lower half & 14,400 & 12,800 & 13,600 \\
\hline S97T002321 & $224: 1$ & Lower half & 16,900 & 14,800 & 15,800 \\
\hline S98T000725 & $224: 2$ & Whole & 2,340 & 2,680 & 2,510 \\
\hline S97T002335 & $224: 3$ & Lower half & 5,900 & 7,990 & $6,940^{\mathrm{eC}: \mathrm{e}}$ \\
\hline S98T000726 & $224: 4$ & Whole & 2,320 & 2,440 & 2,380 \\
\hline S97T002354 & \multirow[t]{2}{*}{$224: 5$} & Upper half & 17,900 & 17,000 & 17,400 \\
\hline S97T002353 & & Lower half & 13,500 & 11,600 & 12,600 \\
\hline S97T002356 & \multirow[t]{2}{*}{$224: 6$} & Upper half & 8,630 & 8,630 & 8,630 \\
\hline S97T002355 & & Lower half & 10,100 & 5,890 & $8,000^{\mathrm{QC}: c}$ \\
\hline S98T000727 & $224: 7$ & Whole & 3,700 & 3,780 & 3,740 \\
\hline S97T002358 & \multirow[t]{2}{*}{$224: 8$} & Upper half & 11,600 & 11,700 & 11,700 \\
\hline S97T002357 & & Lower half & 8,870 & 10,300 & 9,590 \\
\hline S97T002393 & \multirow[t]{2}{*}{$224: 9$} & Upper half & 5,960 & 4,910 & 5,430 \\
\hline S97T002388 & & Lower half & 17,600 & 19,700 & 18,600 \\
\hline S98T000728 & 224:10 & Whole & 2,890 & 2,980 & 2,930 \\
\hline S97T002403 & \multirow[t]{2}{*}{$224: 11$} & Upper half & 20,500 & 21,300 & 20,900 \\
\hline S97T002398 & & Lower half & 29,400 & 31,100 & 30,200 \\
\hline
\end{tabular}


Table B2-51. Tank 241-SX-106 Analytical Results: Phosphate (IC). (2 sheets)

\begin{tabular}{|c|c|c|c|c|c|}
\hline Murainger & 1260109161 & sample & Resulu & Majlicare & rienin \\
\hline Wingins & 样 & 荸. & $20 \% 10$ & $69 \mathrm{~mm}$ & 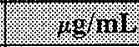 \\
\hline S97T002179 & 223:1 & Drainable liquid & 2,650 & 2,920 & 2,780 \\
\hline S97T002188 & $223: 2$ & Drainable liquid & 2,680 & 2,980 & 2,830 \\
\hline S97T002199 & $223: 3$ & Drainable liquid & 2,620 & 2,970 & 2,800 \\
\hline S97T002200 & $223: 4$ & Drainable liquid & 2,780 & 2,760 & 2,770 \\
\hline S97T002215 & $223: 5$ & Drainable liquid & 4,680 & 3,960 & 4,320 \\
\hline S97T002323 & $224: 1$ & Drainable liquid & 3,560 & 3,840 & 3,700 \\
\hline$\$ 97 T 002371$ & $224: 3$ & Drainable liquid & 3,330 & 3,240 & 3,290 \\
\hline S97T002372 & $224: 5$ & Drainable liquid & 3,370 & 3,220 & 3,290 \\
\hline
\end{tabular}


Table B2-52. Tank 241-SX-106 Analytical Results: Sulfate (IC). (2 sheets)

\begin{tabular}{|c|c|c|c|c|c|}
\hline Sample & Samplo & gample & Resilit & Bribluare & Mera \\
\hline \multicolumn{3}{|c|}{ 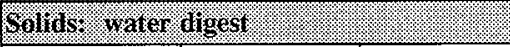 } & . & .498 & .1696 \\
\hline S97T002178 & $223: 1$ & Lower half & 1,390 & 1,330 & 1,360 \\
\hline S97T002186 & $223: 2$ & Lower half & 2,710 & 3,190 & 2,950 \\
\hline S97T002196 & $223: 3$ & Lower half & 2,200 & 2,910 & $2,550^{\mathrm{QC}: \mathrm{e}}$ \\
\hline S97T002205 & $223: 4$ & Lower half & 1,390 & 1,400 & 1,390 \\
\hline \$97T002237 & $223: 5$ & Lower half & $<2820$ & $<2670$ & $<2750$ \\
\hline \$98T000696 & $223: 6$ & Whole & 5,550 & 4,560 & 5,050 \\
\hline S98T000707 & $223: 6 \mathrm{~A}$ & Whole & 4,440 & 4,220 & 4,330 \\
\hline \$97T002239 & \multirow[t]{2}{*}{$223: 7$} & Upper half & 8,880 & 7,510 & 8,200 \\
\hline S97T002238 & & Lower half & 4,920 & 4,350 & 4,630 \\
\hline S97T002241 & \multirow[t]{2}{*}{$223: 8$} & Upper half & 5,140 & 4,820 & 4,980 \\
\hline S97T002240 & & Lower half & 3,450 & 3,150 & 3,300 \\
\hline S98T000708 & $223: 9$ & Whole & 1,430 & 1,450 & 1,440 \\
\hline \$97T002266 & \multirow[t]{2}{*}{$223: 10$} & Upper half & 8,700 & 8,220 & 8,460 \\
\hline S97T002264 & & Lower half & 22,900 & 26,300 & 24,600 \\
\hline S97T002321 & $224: 1$ & Lower half & 3,330 & 3,740 & 3,530 \\
\hline S98T000725 & $224: 2$ & Whole & 1,610 & 1,930 & 1,770 \\
\hline \$97T002335 & $224: 3$ & Lower half & 3,910 & 3,550 & 3,730 \\
\hline S98T000726 & $224: 4$ & Whole & 1,900 & 1,800 & 1,850 \\
\hline S97T002354 & \multirow[t]{2}{*}{$224: 5$} & Upper half & 3,440 & 3,740 & 3,590 \\
\hline \$97T002353 & & Lower half & 9,720 & 9,650 & 9,680 \\
\hline S97T002356 & \multirow[t]{2}{*}{$224: 6$} & Upper half & 6,850 & 7,000 & 6,920 \\
\hline S97T002355 & & Lower half & 6,630 & 5,790 & 6,210 \\
\hline \$98T000727 & $224: 7$ & Whole & 5,130 & 5,090 & 5,110 \\
\hline \$97T002358 & \multirow[t]{2}{*}{$224: 8$} & Upper half & 7,700 & 7,720 & 7,710 \\
\hline S97T002357 & & Lower half & 8,710 & 6,390 & $7,550^{\mathrm{QC:e}}$ \\
\hline S97T002393 & \multirow[t]{2}{*}{$224: 9$} & Upper half & 2,250 & 3,770 & $3,010^{\mathrm{QC:c}}$ \\
\hline S97T002388 & & Lower half & 6,830 & 4,020 & $5,430^{\mathrm{QC}-\mathrm{c}}$ \\
\hline \$98T000728 & $224: 10$ & Whole & 3,570 & 3,540 & 3,560 \\
\hline S97T002403 & \multirow[t]{2}{*}{$224: 11$} & Upper half & 2,500 & 3,130 & $2,810^{\mathrm{QC:e}}$ \\
\hline S97T002398 & & Lower half & 2,970 & 4,120 & $3,550^{\mathrm{QC:c}}$ \\
\hline
\end{tabular}


Table B2-52. Tank 241-SX-106 Analytical Results: Sulfate (IC). (2 sheets)

\begin{tabular}{|c|c|c|c|c|c|}
\hline $\begin{array}{l}\text { Sample } \\
\text { Number }\end{array}$ & Shavple & Sample & Resulil & Brylueare & Mean \\
\hline Kignids & (: & 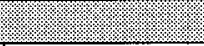 & 19: & rg:min. &., $59 \mathrm{mil}$ \\
\hline S97T002179 & $223: 1$ & Drainable liquid & 5,900 & 6,120 & 6,010 \\
\hline S97T002188 & $223: 2$ & Drainable liquid & 5,230 & 5,400 & 5,320 \\
\hline S97T002199 & $223: 3$ & Drainable liquid & 4,870 & 4,950 & 4,910 \\
\hline S97T002200 & $223: 4$ & Drainable liquid & 4,850 & 5,690 & 5,270 \\
\hline S97T002215 & $223: 5$ & Drainable liquid & 5,350 & 5,290 & 5,320 \\
\hline S97T002323 & $224: 1$ & Drainable liquid & 4,280 & 6,330 & $5,300^{\mathrm{QC}: \mathrm{e}}$ \\
\hline S97T002371 & $224: 3$ & Drainable liquid & 5,230 & 6,410 & $5,820^{\mathrm{QC}: \mathrm{e}}$ \\
\hline S97T002372 & $224: 5$ & Drainable liquid & 5,550 & 5,080 & 5,320 \\
\hline
\end{tabular}


HNF-SD-WM-ER-645 Rev. 1

Table B2-53. Tank 241-SX-106 Analytical Results: Oxalate (IC). (2 sheets)

\begin{tabular}{|c|c|c|c|c|c|}
\hline Sample & Somprotor & Samplo & Resuly & Buplisale. & Mean \\
\hline \multicolumn{2}{|c|}{ Solids water dugest } & . & $m_{0}$ & 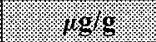 & 1089 \\
\hline \$97T002178 & 223:1 & Lower half & $<808$ & $<818$ & $<813$ \\
\hline S97T002186 & $223: 2$ & Lower half & $<791$ & $<753$ & $<772$ \\
\hline S97T002196 & $223: 3$ & Lower half & $<962$ & $<976$ & $<969$ \\
\hline \$97T002205 & $223: 4$ & Lower half & 1,690 & 1,310 & $1,500^{\mathrm{eC:e}}$ \\
\hline \$97T002237 & $223: 5$ & Lower half & 4,210 & 4,390 & 4,300 \\
\hline \$98T000696 & $223: 6$ & Whole & 4,550 & 3,800 & 4,180 \\
\hline \$98T000707 & $223: 6 \mathrm{~A}$ & Whole & 5,500 & 5,290 & 5,390 \\
\hline \$97T002239 & \multirow[t]{2}{*}{$223: 7$} & Upper half & 16,000 & 14,500 & 15,300 \\
\hline \$97T002238 & & Lower half & 11,400 & 11,100 & 11,200 \\
\hline S97T002241 & \multirow[t]{2}{*}{$223: 8$} & Upper half & 7,400 & 6,980 & 7,190 \\
\hline \$97T002240 & & Lower half & 5,470 & 5,020 & 5,250 \\
\hline \$98T000708 & $223: 9$ & Whole & 2,500 & 2,620 & 2,560 \\
\hline \$97T002266 & \multirow[t]{2}{*}{$223: 10$} & Upper half & 13,100 & 13,900 & 13,500 \\
\hline S97T002264 & & Lower half & 16,200 & 24,800 & $20,500^{\mathrm{Qc:e}}$ \\
\hline \$97T002321 & $224: 1$ & Lower half & $<793$ & $<860$ & $<827$ \\
\hline S98T000725 & $224: 2$ & Whole & $<424$ & $<425$ & $<425$ \\
\hline S97T002335 & $224: 3$ & Lower half & $<804$ & $<806$ & $<805$ \\
\hline S98T000726 & $224: 4$ & Whole & $<426$ & $<433$ & $<429$ \\
\hline S97T002354 & \multirow[t]{2}{*}{$224: 5$} & Upper half & 2,470 & 2,040 & 2,250 \\
\hline S97T002353 & & Lower half & 11,900 & 12,600 & 12,200 \\
\hline S97T002356 & \multirow[t]{2}{*}{$224: 6$} & Upper half & 9,930 & 10,400 & 10,200 \\
\hline S97T002355 & & Lower half & 11,400 & 9,790 & 10,600 \\
\hline S98T000727 & $224: 7$ & Whole & 2,650 & 4,410 & $3,530^{\mathrm{QC}: \mathrm{e}}$ \\
\hline S97T002358 & \multirow[t]{2}{*}{$224: 8$} & Upper half & 9,520 & 9,890 & 9,700 \\
\hline \$97T002357 & & Lower half & 8,630 & 9,120 & 8,880 \\
\hline S97T002393 & \multirow[t]{2}{*}{$224: 9$} & Upper half & 4,040 & 4,740 & 4,390 \\
\hline \$97T002388 & & Lower half & 11,900 & 8,080 & $9,970^{\text {QC:e }}$ \\
\hline S98T000728 & $224: 10$ & Whole & 3,580 & 3,480 & 3,530 \\
\hline S97T002403 & \multirow[t]{2}{*}{$224: 11$} & Upper half & 7,300 & 8,540 & 7,920 \\
\hline \$97T002398 & & Lower half & 8,270 & 11,000 & $9,630^{\mathrm{QC}: \mathrm{e}}$ \\
\hline
\end{tabular}


Table B2-53. Tank 241-SX-106 Analytical Results: Oxalate (IC). (2 sheets)

\begin{tabular}{|c|c|c|c|c|c|}
\hline $\begin{array}{l}\text { Sampié } \\
\text { number }\end{array}$ & Soramples & $\begin{array}{l}\text { Sranple } \\
\text { Pontion }\end{array}$ & Resin: & Bupliente & lenen \\
\hline Miguids : & & & 198,131 & $18 \mathrm{~g} / \mathrm{ml}$ & $r \mathrm{glml}$ \\
\hline S97T002179 & 223:1 & Drainable liquid & $<541$ & $<541$ & $<541$ \\
\hline S97T002188 & $223: 2$ & Drainable liquid & $<541$ & $<541$ & $<541$ \\
\hline S97T002199 & $223: 3$ & Drainable liquid & 659 & $<541$ & $<600$ \\
\hline S97T002200 & $223: 4$ & Drainable liquid & $<541$ & $<541$ & $<541$ \\
\hline S97T002215 & $223: 5$ & Drainable liquid & $<1,070$ & $<1,070$ & $<1,070$ \\
\hline S97T002323 & $224: 1$ & Drainable liquid & $<1,070$ & 1,160 & $<1,120$ \\
\hline S97T002371 & $224: 3$ & Drainable liquid & $<1,070$ & $<1,070$ & $<1,070$ \\
\hline S97T002372 & $224: 5$ & Drainable liquid & $<541$ & 902 & $<721^{\text {QC:e }}$ \\
\hline
\end{tabular}


Table B2-54. Tank 241-SX-106 Analytical Results: Total Inorganic Carbon (TIC).

(2 sheets)

\begin{tabular}{|c|c|c|c|c|c|c|}
\hline Sampic & Sormulier & . Sarole & Resull & 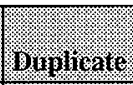 & Mroncate & yean \\
\hline Solios. & & & \%go & (19) & 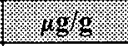 & 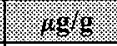 \\
\hline \$97T002176 & $223: 1$ & Lower half & 1,560 & 1,590 & & 1,580 \\
\hline S97T002183 & $223: 2$ & Lower half & 3,140 & 3,570 & & 3,360 \\
\hline S97T002191 & $223: 3$ & Lower half & 1,660 & 1,520 & 1,400 & $1,530^{\mathrm{QC:c}}$ \\
\hline S97T002192 & $223: 4$ & Lower half & 1,960 & 2,720 & 2,270 & $2,320^{\mathrm{QC}: \mathrm{e}}$ \\
\hline \$97T002218 & $223: 5$ & Lower half & 4,960 & 4,970 & & 4,970 \\
\hline S98T000692 & $223: 6$ & Whole & 6,350 & 6,400 & & 6,380 \\
\hline S98T000697 & $223: 6 \mathrm{~A}$ & Whole & 5,350 & 5,330 & & 5,340 \\
\hline \$97T002220 & \multirow[t]{2}{*}{$223: 7$} & Upper half & 10,300 & 9,500 & & 9,900 \\
\hline S97T002226 & & Lower half & 6,260 & 6,280 & & 6,270 \\
\hline S97T002223 & \multirow[t]{2}{*}{$223: 8$} & Upper half & 8,080 & 8,090 & & 8,090 \\
\hline S97T002229 & & Lower half & 4,910 & 4,220 & & 4,570 \\
\hline S98T000698 & $223: 9$ & Whole & 2,390 & 2,260 & & 2,330 \\
\hline S97T002262 & \multirow[t]{2}{*}{$223: 10$} & Upper half & 3,440 & 4,000 & & 3,720 \\
\hline \$97T002259 & & Lower half & 5,270 & 5,210 & & 5,240 \\
\hline \$97T002318 & $224: 1$ & Lower half & 2,820 & 3,030 & & 2,930 \\
\hline S98T000709 & $224: 2$ & Whole & 2,000 & 2,040 & & 2,020 \\
\hline S97T002333 & $224: 3$ & Lower half & 1,970 & 1,710 & & 1,840 \\
\hline S98T000710 & $224: 4$ & Whole & 2,280 & 2,250 & & 2,270 \\
\hline S97T002348 & \multirow[t]{2}{*}{$224: 5$} & Upper half & 2,510 & 2,620 & & 2,570 \\
\hline S97T002347 & & Lower half & 10,100 . & 10,200 & & 10,200 \\
\hline \$97T002350 & \multirow[t]{2}{*}{$224: 6$} & Upper half & 9,110 & 9,550 & & 9,330 \\
\hline S97T002349 & & Lower half & 7,290 & 7,970 & & 7,630 \\
\hline S98T000711 & $224: 7$ & Whole & 4,410 & 4,190 & 4,390 & 4,330 \\
\hline S97T002352 & \multirow[t]{2}{*}{$224: 8$} & Upper half & 6,530 & 6,670 & & 6,600 \\
\hline S97T002351 & & Lower half & 4,500 & 4,640 & & 4,570 \\
\hline S97T002390 & \multirow[t]{2}{*}{$224: 9$} & Upper half & 1,880 & 1,610 & & 1,750 \\
\hline S97T002385 & & Lower half & 1,920 & 1,990 & & $1,960^{\mathrm{QC:c}}$ \\
\hline S98T000712 & $224: 10$ & Whole & 3,790 & 3,780 & & 3,790 \\
\hline S97T002400 & \multirow[t]{2}{*}{$224: 11$} & Upper half & 2,260 & 2,590 & & 2,430 \\
\hline S97T002395 & & Lower half & 3,150 & 3,170 & & 3,160 \\
\hline
\end{tabular}


Table B2-54. Tank 241-SX-106 Analytical Results: Total Inorganic Carbon (TIC). ( 2 sheets)

\begin{tabular}{|c|c|c|c|c|c|c|}
\hline $\begin{array}{l}\text { Sample: } \\
\text { Samiler }\end{array}$ & $\begin{array}{l}\text { Sample } \\
\text { Soration }\end{array}$ & : Sample & Restill & Buploate & Miplicate & Mean \\
\hline Mrunus & 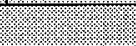 & 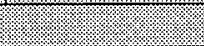 & $8.9 .1 \mathrm{mi}$ & $1 / \mathrm{g} / \mathrm{mil}$ & (18.1n! & 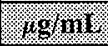 \\
\hline S97T002179 & $223: 1$ & Drainable liquid & 4,790 & 4,730 & & 4,760 \\
\hline S97T002188 & $223: 2$ & Drainable liquid & 5,120 & 5,110 & & 5,120 \\
\hline S97T002199 & $223: 3$ & Drainable liquid & 4,800 & 5,300 & & 5,050 \\
\hline S97T002200 & 223:4 & Drainable liquid & 5,340 & 5,650 & & 5,500 \\
\hline S97T002215 & $223: 5$ & Drainable liquid & 5,290 & 5,480 & & 5,390 \\
\hline S97T002323 & $224: 1$ & Drainable liquid & 4,670 & 5,140 & & 4,910 \\
\hline S97T002371 & $224: 3$. & Drainable liquid & 5,180 & 5,130 & & 5,160 \\
\hline S97T002372 & $224: 5$ & Drainable liquid & 4,980 & 5,190 & & 5,090 \\
\hline
\end{tabular}


Table B2-55. Tank 241-SX-106 Analytical Results: Total Organic Carbon (TOC). (2 sheets)

\begin{tabular}{|c|c|c|c|c|c|c|}
\hline $\begin{array}{l}\text { Sampler } \\
\text { Number }\end{array}$ & $\begin{array}{l}\text { Sample } \\
\text { I vecarion }\end{array}$ & $\begin{array}{l}\text { Sample } \\
\text { Portion }\end{array}$ & Resulit & Buylicate & VTiplicater & Mean \\
\hline Solins & 8. & & $08 \mathrm{~g}$ & $18 \mathrm{~g} \cdot \mathrm{s}$ & 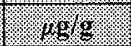 & $10.6 \%$ \\
\hline S97T002176 & $223: 1$ & Lower half & 1,240 & 1,260 & & 1,250 \\
\hline S97T002183 & $223: 2$ & Lower half & 2,630 & 2,860 & & 2,750 \\
\hline S97T002191 & $223: 3$ & Lower half & 1,360 & 1,220 & 1,110 & $1,230^{\alpha \mathrm{C}: \mathrm{c}}$ \\
\hline S97T002192 & 223:4 & Lower half & 1,250 & 2,030 & 1,560 & $1,610^{\mathrm{eC}: \mathrm{e}}$ \\
\hline S97T002218 & $223: 5$ & Lower half & 3,640 & 3,560 & & 3,600 \\
\hline S98T000692 & 223:6. & Whole & 2,450 & 2,430 & & 2,440 \\
\hline S98T000697 & $223: 6 \mathrm{~A}$ & Whole & 2,570 & 2,750 & & 2,660 \\
\hline S97T002220 & \multirow[t]{2}{*}{$223: 7$} & Upper half & 6,370 & 6,450 & & 6,410 \\
\hline S97T002226 & & Lower half & 5,040 & 4,870 & & 4,960 \\
\hline S97T002223 & \multirow[t]{2}{*}{$223: 8$} & Upper half & 4,450 & 4,630 & & 4,540 \\
\hline S97T002229 & & Lower half & 2,930 & 3,080 & & 3,010 \\
\hline S98T000698 & 223:9 & Whole & 1,980 & 2,830 & & $2,410^{\mathrm{eC}: e}$ \\
\hline S97T002262 & \multirow[t]{2}{*}{$223: 10$} & Upper half & 3,230 & 3,540 & & 3,390 \\
\hline S97T002259 & & Lower half & 4,000 & 3,990 & & 4,000 \\
\hline S97T002318 & $224: 1$ & Lower half & 2,720 & 2,310 & & 2,520 \\
\hline S98T000709 & $224: 2$ & Whole & 1,590 & 1,570 & & 1,580 \\
\hline S97T002333 & $224: 3$ & Lower half & 1,410 & 1,270 & & 1,340 \\
\hline S98T000710 & $224: 4$ & Whole & 1,410 & 1,490 & & 1,450 \\
\hline S97T002348 & \multirow[t]{2}{*}{$224: 5$} & Upper half & 1,830 & 1,740 & & 1,790 \\
\hline S97T002347 & & Lower half & 6,170 & 5,790 & & 5,980 \\
\hline S97T002350 & \multirow[t]{2}{*}{$224: 6$} & Upper half & 6,410 & 6,030 & & 6,220 \\
\hline S97T002349 & & Lower half & 6,110 & 6,640 & & 6,380 \\
\hline S98T000711 & $224: 7$ & Whole & 2,150 & 3,350 & 2,040 & $2,510^{\mathrm{QC}: \mathrm{c}}$ \\
\hline S97T002352 & \multirow[t]{2}{*}{$224: 8$} & Upper half & 5,030 & 4,870 & & 4,950 \\
\hline S97T002351 & & Lower half & 3,880 & 3,970 & & 3,930 \\
\hline S97T002390 & \multirow[t]{2}{*}{$224: 9$} & Upper half & 2,600 & 2,130 & & 2,370 \\
\hline S97T002385 & & Lower half & 3,000 & 2,610 & & 2,810 \\
\hline S98T000712 & $224: 10$ & Whole & 2,240 & 3,440 & 2,260 & $2,650^{\mathrm{QC}: \mathrm{e}}$ \\
\hline S97T002400 & \multirow[t]{2}{*}{$224: 11$} & Upper half & 3,600 & 2,810 & & $3,210^{\mathrm{QC} \cdot \mathrm{c}}$ \\
\hline S97T002395 & & Lower half & 3,810 & 3,860 & & 3,840 \\
\hline
\end{tabular}


Table B2-55. Tank 241-SX-106 Analytical Results: Total Organic Carbon (TOC). (2 sheets)

\begin{tabular}{|c|c|c|c|c|c|c|}
\hline $\begin{array}{l}\text { Sanple } \\
\text { Number }\end{array}$ & $\begin{array}{l}\text { Soniple } \\
\text { legention }\end{array}$ & $\begin{array}{l}\text { Sample } \\
\text { Portion }\end{array}$ & Mesulit & Guplicate & Hiolicare & Mean \\
\hline Mriquids & (2: & 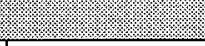 & $189 \mathrm{nin}$ & $189 \mathrm{~m}$ & $4 \mathrm{~g} / \mathrm{mi}$ & $18.8 \% 101$ \\
\hline S97T002179 & 223:1 & Drainable liquid & 3,840 & 3,860 & & 3,850 \\
\hline S97T002188 & $223: 2$ & Drainable liquid & 3,870 & 3,850 & & 3,860 \\
\hline S97T002199 & $223: 3$ & Drainable liquid & 3,680 & 4,060 & & 3,870 \\
\hline S97T002200 & 223:4 & Drainable liquid & 4,120 & 4,370 & & 4,250 \\
\hline S97T002215 & $223: 5$ & Drainable liquid & 4,430 & 4,560 & & 4,500 \\
\hline S97T002323 & $224: 1$ & Drainable liquid & 3,870 & 4,110 & & 3,990 \\
\hline S97T002371 & $224: 3$ & Drainable liquid & 4,090 & 4,080 & & 4,090 \\
\hline S97T002372 & $224: 5$ & Drainable liquid & 3,970 & 4,080 & & 4,030 \\
\hline
\end{tabular}

Table B2-56. Tank 241-SX-106 Analytical Results: Total Organic Carbon (TOC).

\begin{tabular}{|c|c|c|c|c|c|}
\hline Samile & S Sample & $\begin{array}{l}\text { Samivile } \\
\text { Iortion }\end{array}$ & Result & Buplicase & Mean \\
\hline Sollows: yol & figesis. & 8 & 筒. & $110 \mathrm{~g} / \mathrm{g}$ & $1 . \mathrm{g} / \mathrm{s}$ \\
\hline S97T002403 & $224: 11$ & Upper half & 8,730 & 6,730 & $7,730^{\mathrm{QC}: \mathrm{e}}$ \\
\hline
\end{tabular}


Table B2-57. Tank 241-SX-106 Analytical Results: Total Alpha.

\begin{tabular}{|c|c|c|c|c|c|}
\hline Sample: & Sample & $\begin{array}{l}\text { Samilie } \\
\text { Porition }\end{array}$ & Result: & Divolicare & Yran \\
\hline \multicolumn{2}{|c|}{ Sqlify : finson } & : & $1.0 \% 19$ & $11-1 / 8$ & $2.1 .1 .6 \mathrm{~g}$ \\
\hline S97T002177 & $223: 1$ & Lower half & $<0.00939$ & $<0.00779$ & $<0.00859^{\mathrm{eC}: \mathrm{c}}$ \\
\hline S97T002185 & $223: 2$ & Lower half & $<0.016$ & $<0.0118$ & $<0.0139^{\text {QC:e }}$ \\
\hline S97T002194 & $223: 3$ & Lower half & $<0.0129$ & $<0.0156$ & $<0.0143^{\text {QC:c }}$ \\
\hline S97T002204 & $223: 4$ & Lower half & $<0.0243$ & 0.0238 & $<0.0241$ \\
\hline S97T002231 & $223: 5$ & Lower half & 0.0456 & 0.0483 & $0.047^{\mathrm{OC}: \mathrm{f}}$ \\
\hline S98T000694 & $223: 6$ & Whole & 0.12 & 0.132 & 0.126 \\
\hline S98T000703 & $223: 6 \mathrm{~A}$ & Whole & 0.181 & 0.194 & 0.188 \\
\hline S97T002232 & $223: 7$ & Lower half & 0.409 & 0.441 & 0.425 \\
\hline S97T002234 & 223:8 & Lower half & 0.0955 & 0.0744 & $0.085^{\mathrm{QC}: \mathrm{e}}$ \\
\hline S98T000704 & $223: 9$ & Whole & 0.155 & 0.167 & 0.161 \\
\hline S97T002263 & $223: 10$ & Lower half & 0.498 & 0.469 & 0.484 \\
\hline S97T002320 & $224: 1$ & Lower half & $<0.0092$ & $<0.00893$ & $<0.00907$ \\
\hline S98T000717 & $224: 2$ & Whole & 0.00901 & 0.0102 & 0.00961 \\
\hline S97T002334 & $224: 3$ & Lower half & $<0.00884$ & $<0.00893$ & $<0.00889$ \\
\hline S98T000718 & $224: 4$ & Whole & $<0.00525$ & $<0.00442$ & $<0.00484$ \\
\hline S97T002359 & $224: 5$ & Lower half & 0.311 & 0.352 & 0.332 \\
\hline S97T002361 & $224: 6$ & Lower half & 0.367 & 0.429 & 0.398 \\
\hline S98T000719 & $224: 7$ & Whole & 0.122 & 0.129 & 0.126 \\
\hline S97T002363 & $224: 8$ & Lower half & 0.51 & 0.472 & 0.491 \\
\hline S97T002387 & $224: 9$ & Lower half & 1.27 & 1.25 & 1.26 \\
\hline S98T000720 & $224: 10$ & Whole & 0.431 & 0.369 & 0.4 \\
\hline S97T002397 & $224: 11$ & Lower half & 0.618 & 0.578 & 0.598 \\
\hline Migurds: & 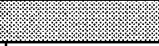 & 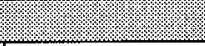 & (19.1m & (1) & 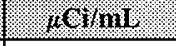 \\
\hline S97T002179 & $223: 1$ & Drainable liquid & 0.00473 & $<0.00317$ & $<0.00395^{\text {QC:ce }}$ \\
\hline S97T002188 & $223: 2$ & Drainable liquid & $<0.00317$ & $<0.00317$ & $<0.00317^{\text {QC:t }}$ \\
\hline S97T002199 & $223: 3$ & Drainable liquid & 0.00286 & 0.00473 & $0.0038^{\mathrm{QC}: c, f}$ \\
\hline S97T002200 & 223:4 & Drainable liquid & $<0.00655$ & $<0.004$ & $<0.00528$ \\
\hline S97T002215 & $223: 5$ & Drainable liquid & $<0.00174$ & $<0.00232$ & $<0.00203$ \\
\hline
\end{tabular}


Table B2-58. Tank 241-SX-106 Analytical Results: Exotherms Calculated Dry Weight (DSC).

\begin{tabular}{|c|c|c|c|c|c|}
\hline $\begin{array}{l}\text { Sample: } \\
\text { Number }\end{array}$ & $\begin{array}{l}\text { Sample } \\
\text { I ouglion }\end{array}$ & $\begin{array}{l}\text { Sample } \\
\text { Portion }\end{array}$ & Resull & Burlicate & Mran \\
\hline Solidis: & 2: & (2.:-3: & Ho bu & I.g BOW & $11961 \%$ \\
\hline S97T002347 & $224: 5$ & Lower half & 29.2 & 49.4 & $39.3^{\mathrm{QC}: \mathrm{e}}$ \\
\hline S97T002350 & \multirow[t]{2}{*}{$224: 6$} & Upper half & 123 & 126 & 125 \\
\hline S97T002349 & & Lower half & 137 & 142 & 140 \\
\hline S97T002400 & $224: 11$ & Upper half & 280 & 258 & 269 \\
\hline Wiguas. & 4 & 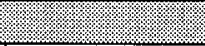 & $18 \mathrm{~g})$ & $139 \mathrm{OHW}$ & $.1 \% 9.0 W$ \\
\hline S97T002199 & $223: 3$ & Drainable liquid & 15.2 & 15.5 & 15.3 \\
\hline
\end{tabular}

Table B2-59. Tank 241-SX-106 Analytical Results: Exotherm - Transition 1 (DSC/TGA).

\begin{tabular}{|c|c|c|c|c|c|}
\hline $\begin{array}{l}\text { Sample: } \\
\text { Vumber }\end{array}$ & Sample: & $\begin{array}{l}\text { Sample } \\
\text { Dortion }\end{array}$ & Resnilt & Blaphicure & Mean \\
\hline Solvis & $2:=0.0$ & (: & 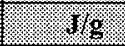 & (2. & (1) $1 / 2$ \\
\hline S97T002347 & $224: 5$ & Lower half & 16.2 & 27.5 & $21.9^{\mathrm{OC}: \mathrm{e}}$ \\
\hline S97T002350 & $224: 6$ & Upper half & 70.5 & 72.4 & 71.4 \\
\hline S97T002349 & & Lower half & 77.4 & 80.4 & 78.9 \\
\hline$\$ 97 \mathrm{~T} 002400$ & $224: 11$ & Upper half & 155 & 143 & 149 \\
\hline Tinguds: & I. & 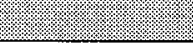 & $1 / 8$ & 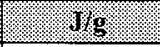 & $1 / 19$ \\
\hline S97T002199 & $223: 3$ & Drainable liquid & 7.4 & 7.55 & 7.47 \\
\hline
\end{tabular}


HNF-SD-WM-ER-645 Rev. 1

Table B2-60. Tank 241-SX-106 Analytical Results: Percent Water (DSC/TGA). (2 sheets)

\begin{tabular}{|c|c|c|c|c|c|c|}
\hline Sariple & saviole & sample & Iresulit & Ouplicate & 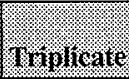 & \% \\
\hline Solids. & & & . & $\sqrt{2} .7 \%$ & 60 & $\%$ \\
\hline S97T002176 & 223:1 & Lower half & 36.5 & 34.7 & & 35.6 \\
\hline S97T002183 & $223: 2$ & Lower half & 51.4 & 49.5 & & 50.4 \\
\hline S97T002191 & $223: 3$ & Lower half & 28.8 & 37.2 & & 33 \\
\hline S97T002192 & $223: 4$ & Lower half & 37.7 & 35.5 & & 36.6 \\
\hline S97T002218 & $223: 5$ & Lower half & 48.2 & 48.6 & & 48.4 \\
\hline S98T000692 & $223: 6$ & Whole & 67 & 66 & & 66.5 \\
\hline S98T000697 & $223: 6 \mathrm{~A}$ & Whole & 66.8 & 67.5 & & 67.2 \\
\hline S97T002220 & \multirow[t]{2}{*}{$223: 7$} & Upper half & 42.2 & 41.9 & & 42 \\
\hline S97T002226 & & Lower half & 42.2 & 42.3 & & 42.3 \\
\hline S97T002223 & \multirow[t]{2}{*}{$223: 8$} & Upper half & 42.7 & 45.5 & & 44.1 \\
\hline S97T002229 & & Lower half & 37.3 & 41.3 & & 39.3 \\
\hline S98T000698 & $223: 9$ & Whole & 62 & 61.7 & & 61.9 \\
\hline \$97T002262 & \multirow[t]{2}{*}{$223: 10$} & Upper half & 21.6 & 23 & & 22.3 \\
\hline S97T002259 & & Lower half & 21.6 & 26.9 & & 24.3 \\
\hline S97T002318 & $224: 1$ & Lower half & 50 & 49.4 & & 49.7 \\
\hline S98T000709 & $224: 2$ & Whole & 70.3 & 69.5 & & 69.9 \\
\hline \$97T002333 & $224: 3$ & Lower half & 48.8 & 48.8 & & 48.8 \\
\hline S98T000710 & $224: 4$ & Whole & 68.4 & 66.3 & & 67.4 \\
\hline S97T002348 & \multirow[t]{2}{*}{$224: 5$} & Upper half & 48.7 & 48.9 & & 48.8 \\
\hline S97T002347 & & Lower half & 43.5 & 45.2 & & 44.3 \\
\hline S97T002350 & \multirow[t]{2}{*}{$224: 6$} & Upper half & 42.7 & 43.1 & & 42.9 \\
\hline S97T002349 & & Lower half & 43.1 & 43.9 & & 43.5 \\
\hline S98T000711 & $224: 7$ & Whole & 55.9 & 62 & & 59 \\
\hline S97T002352 & \multirow[t]{2}{*}{$224: 8$} & Upper half & 35.5 & 35.3 & & 35.4 \\
\hline S97T002351 & & Lower half & 26.1 & 31.1 & & 28.6 \\
\hline S97T002390 & \multirow[t]{2}{*}{$224: 9$} & Upper half & 35.6 & 24.5 & 30.3 & $30.1^{\mathrm{QC}: \mathrm{e}}$ \\
\hline S97T002385 & & Lower half & 30 & 31.6 & & 30.8 \\
\hline S98T000712 & $224: 10$ & Whole & 56.2 & 54.9 & & 55.6 \\
\hline S97T002400 & \multirow[t]{2}{*}{$224: 11$} & Upper half & 46.1 & 42.9 & & 44.5 \\
\hline S97T002395 & & Lower half & 31 & 31.6 & & 31.3 \\
\hline
\end{tabular}


Table B2-60. Tank 241-SX-106 Analytical Results: Percent Water (DSC/TGA). (2 sheets)

\begin{tabular}{|c|c|c|c|c|c|c|}
\hline $\begin{array}{l}\text { Sample } \\
\text { Vumiber. }\end{array}$ & $\begin{array}{l}\text { Sanule } \\
\text { U oecation }\end{array}$ & $\begin{array}{l}\text { Sample } \\
\text { frortion }\end{array}$ & Resuli & Briplicate & Mropiluate & Mean \\
\hline Higids: & & 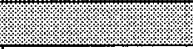 & $3.8 \%$ & (18. & 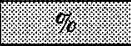 & 8.8 \\
\hline S97T002179 & \multirow{2}{*}{$223: 1$} & Drainable liquid & 19.3 & 22.4 & & 20.9 \\
\hline S97T002179RR1 & & Drainable liquid & 31 & 35.1 & & 33 \\
\hline S97T002188 & 2223:2 & Drainable liquid & 51 & 50.8 & & 50.9 \\
\hline S97T002199 & $223: 3$ & Drainable liquid & 51.2 & 51.2 & & 51.2 \\
\hline S97T002200 & $223: 4$ & Drainable liquid & 51.5 & 51.5 & & 51.5 \\
\hline S97T002215 & $223: 5$ & Drainable liquid & 49.8 & 49.9 & & 49.8 \\
\hline S97T002323 & $224: 1$ & Drainable liquid & 51.1 & 49.6 & & 50.3 \\
\hline S97T002371 & 224:3 & Drainable liquid & 51.2 & 51.1 & & 51.1 \\
\hline S97T002372 & $224: 5$ & Drainable liquid & 50.3 & 49.2 & & 49.8 \\
\hline
\end{tabular}


Table B2-61. Tank 241-SX-106 Analytical Results: Bulk Density.

\begin{tabular}{|c|c|c|c|c|c|}
\hline $\begin{array}{l}\text { Sample } \\
\text { Nunber }\end{array}$ & $\begin{array}{l}\text { Sample } \\
\text { I Iocation }\end{array}$ & $\begin{array}{l}\text { Sample } \\
\text { Sortion }\end{array}$ & Resull & Givilicats. & Mrean. \\
\hline Solios & 4.3. & 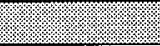 & glinit & ginil & (ami. \\
\hline S97T002175 & $223: 1$ & Lower half & 1.53 & $\mathrm{NA}$ & 1.53 \\
\hline S97T002182 & $223: 2$ & Lower half & 1.42 & NA & 1.42 \\
\hline S97T002190 & 223:3 & Lower half & 1.5 & NA & 1.5 \\
\hline S97T002193 & $223: 4$ & Lower half & 1.56 & $\mathrm{NA}$ & 1.56 \\
\hline S97T002217 & $223: 5$ & Lower half & 1.44 & NA & 1.44 \\
\hline S97T002236 & $223: 6$ & Whole & 1.3 & NA & 1.3 \\
\hline S97T002242 & $223: 6 \mathrm{~A}$ & Whole & 1.32 & NA & 1.32 \\
\hline S97T002225 & $223: 7$ & Lower half & 1.69 & NA & 1.69 \\
\hline S97T002228 & $223: 8$ & Lower half & 1.69 & NA & 1.69 \\
\hline S97T002251 & $223: 9$ & Whole & 1.35 & $\mathrm{NA}$ & 1.35 \\
\hline S97T002258 & $223: 10$ & Lower half & 1.79 & NA & 1.79 \\
\hline S97T002317 & $224: 1$ & Lower half & 1.56 & NA & 1.56 \\
\hline S97T002310 & $224: 2$ & Whole & 1.24 & NA & 1.24 \\
\hline S97T002331 & $224: 3$ & Lower half & 1.61 & NA & 1.61 \\
\hline S97T002327 & $224: 4$ & Whole & 1.25 & NA & 1.25 \\
\hline S97T002336 & $224: 5$ & Lower half & 1.59 & $\mathrm{NA}$ & 1.59 \\
\hline S97T002338 & $224: 6$ & Lower half & 1.68 & $\mathrm{NA}$ & 1.68 \\
\hline S97T002374 & $224: 7$ & Whole & 1.28 & $\mathrm{NA}$ & 1.28 \\
\hline S97T002340 & $224: 8$ & Lower half & 1.68 & NA & 1.68 \\
\hline S97T002384 & $224: 9$ & Lower half & 1.72 & NA & 1.72 \\
\hline S97T002376 & $224: 10$ & Whole & 1.3 & $\mathrm{NA}$ & 1.3 \\
\hline S97T002394 & $224: 11$ & Lower half & 1.65 & NA & 1.65 \\
\hline
\end{tabular}


Table B2-62. Tank 241-SX-106 Analytical Results: Specific Gravity.

\begin{tabular}{|c|c|c|c|c|c|}
\hline $\begin{array}{l}\text { Sampler } \\
\text { Number }\end{array}$ & $\begin{array}{l}\text { Sample } \\
\text { Location }\end{array}$ & $\begin{array}{l}\text { Sample. } \\
\text { Rorfion. }\end{array}$ & Resuil & Byplifate & Mran. \\
\hline Lignids: & & & Irinitiess: & Inutiess & unitiess \\
\hline S97T002179 & 223:1 & Drainable liquid & 1.4 & 1.4 & 1.4 \\
\hline S97T002188 & $223: 2$ & Drainable liquid & 1.4 & 1.41 & 1.4 \\
\hline S97T002199 & $223: 3$ & Drainable liquid & 1.4 & 1.41 & 1.4 \\
\hline S97T002200 & $223: 4$ & Drainable liquid & 1.4 & 1.4 & 1.4 \\
\hline S97T002215 & $223: 5$ & Drainable liquid & 1.41 & 1.45 & 1.43 \\
\hline S97T002323 & $224: 1$ & Drainable liquid & 1.5 & 1.41 & 1.45 \\
\hline S97T002371 & $224: 3$ & Drainable liquid & 1.41 & 1.4 & 1.41 \\
\hline S97T002372 & $224: 5$ & Drainable liquid & 1.42 & 1.44 & 1.43 \\
\hline
\end{tabular}




\section{B3.0 ASSESSMENT OF CHARACTERIZATION RESULTS}

This section discusses the overall quality and consistency of the current sampling results for tank 241-SX-106 and provides the results of an analytical-based inventory calculation.

This section also evaluates sampling and analysis factors that may impact data interpretation. These factors are used to assess overall data quality and consistency and to identify limitations in data use.

\section{B3.1 FIELD OBSERVATIONS}

Two cores, 11 segments each, were expected from this tank during the 1997 core sampling event. Selected segments from core $223(6,6 \mathrm{~A}, 9$, and 11) and core $224(2,4,7$, and 10) were sampled using the RGS. Sample $x$-rays were taken for retained gas samples. While retrieving segment 11 of core 223 , the grapple cable broke, requiring the drill string and sampler to be removed manually. The $\mathrm{x}$-rays of the sampler indicated that it contained lithium bromide solution and air with no sample material present. Therefore, laboratory analyses were not performed on this segment.

\section{B3.2 QUALITY CONTROL ASSESSMENT}

The usual quality control assessment includes an evaluation of the appropriate standard recoveries, spike recoveries, duplicate analyses, and blanks that are performed in conjunction with the chemical analyses. Sample and duplicate pairs with one or more quality control results outside the specified criteria were identified by footnotes in the data summary tables (see Section B2.0).

The standard and spike recovery results provide an estimate of the accuracy of the analysis. If a standard or spike recovery is above or below the given criterion, the analytical results may be biased high or low, respectively. The precision is estimated by the RPD, which is defined as the absolute value of the difference between the primary and duplicate samples, divided by their mean, times 100 .

All of the pertinent quality control tests were conducted on the 1997 core samples, allowing a full assessment regarding the accuracy and precision of the data. The specific criteria for the analytes required by the safety screening DQO were given in the SAP (Jo 1997), whereas the criteria governing the opportunistic analytes were given in DOE (1997). 
The RPD for one of the 39 subsamples was outside the specified acceptance limits for DSC. The heterogeneous material and the small sample size required for these analyses made it difficult to obtain reproducible results. No resampling was requested. The standard recoveries for this analysis were within the required limits'.

The RPD for one of the 39 subsamples analyzed for TGA exceeded the acceptance limit. A triplicate analysis was performed. The standard recoveries for this analysis were within the required limits.

Of the 34 ICP analytes, only lithium was a DQO requirement. The standard recoveries, RPDs, and spike recoveries for the lithium analysis were within the required limits.

Of the eight anions analyzed by $\mathrm{IC}$, only bromide was a DQO required analyte. The standard recoveries, RPDs, and spike recoveries for the bromide analysis were within the required limits.

High RPDs were reported for five subsamples analyzed for TOC by persulfate. Selected subsamples had resampling or triplicate analyses performed. The results of the reanalyses showed little improvement in RPDs. A spike recovery below the quality control range was reported for one sample, which was attributed to the high concentration of this analyte in the sample with respect to the amount of spike standard added. No reanalysis was requested. The standard recoveries for this analysis were within the required limits.

A high RPD was reported for one sample analyzed for TOC by furnace oxidation. This was attributed to sample heterogeneity. No resampling was requested. The standard recovery and spike recovery was within the required limits.

High RPDs were reported for two of the 28 subsamples submitted for total alpha activity analyses. The sample results were near the detection limit, which decreased the precision of the analyses. No resamplings were requested because of the low alpha activity in the samples. Spike recoveries below the quality control range were reported for two subsamples. The spike recoveries were within the laboratory statistical control limits for the quality control standard, and no resamplings were requested. The preparation blanks for some samples showed a small amount of alpha contamination. The levels of these contaminants were inconsequential when compared to the results of the samples. These contaminants did not impact sample data quality. The standard recoveries for this analysis were within the required limits.

In summary, the quality control results were excellent, and the few minor discrepancies mentioned here and footnoted in the data summary tables should not impact either the validity or the use of the data. 


\section{B3.3 DATA CONSISTENCY CHECKS}

This section assesses the data consistency and quality from the tank 241-SX-106 core samples. Comparisons of different analytical methods can help to assess the consistency and quality of the data. In addition, mass and charge balances were calculated for both the supernatant and sludge layers to help assess the overall data consistency.

\section{B3.3.1 Comparison of Results from Different Analytical Methods}

The following data consistency checks compare the results from two analytical methods. Close agreement between the two methods strengthens the credibility of both results, but poor agreement brings the reliability of the data into question. All analytical mean results were taken from the Section B2.0 tables.

A comparison was possible between the supernatant phosphorus and sulfur as analyzed by ICP with phosphate and sulfate as analyzed by IC. No other comparisons were possible because of nondetected values.

The supernatant analytical phosphorus mean result as determined by ICP was $1,150 \mu \mathrm{g} / \mathrm{mL}$, which converts to $3,520 \mu \mathrm{g} / \mathrm{mL}$ of phosphate. This compares well with the IC phosphate mean result of $3,220 \mu \mathrm{g} / \mathrm{mL}$. The RPD between these two phosphate results was 9.0 percent. The supernatant analytical sulfur mean result as determined by ICP was $2,400 \mu \mathrm{g} / \mathrm{mL}$, which converts to $7,180 \mu \mathrm{g} / \mathrm{mL}$ of sulfate. This compares with the IC sulfate mean result of $5,410 \mu \mathrm{g} / \mathrm{mL}$. The RPD between these two sulfate results was 28.2 percent.

\section{B3.3.2 Mass and Charge Balance}

The principal objective in performing mass and charge balances is to determine whether the measurements are consistent. Separate mass and charge balances were calculated for the supernatant and sludge layers because these waste phases were analyzed separately. The results of these comparisons are presented in Sections B3.3.2.1 and B3.3.2.2.

B3.3.2.1 Solids Mass and Charge Balance. In calculating the mass and charge balances for the sludge layer, only those analytes listed in Table 3-7 that were detected at a concentration of $1,000 \mu \mathrm{g} / \mathrm{g}$ or greater were considered. With the exception of sodium, all cations listed in Table B3-1 were assumed to be in their most common hydroxide or oxide form, and the concentrations of the assumed species were calculated stoichiometrically. Because precipitates are neutral species, all positive charge was attributed to the sodium cation. Aluminum is assumed to be present as aluminate. The anions listed in Table B3-2 were assumed to be present as sodium salts and were expected to balance the positive charge exhibited by the sodium. The carbonate value was derived from the TIC analyses. The acetate data was derived from the TOC analyses. Phosphate and sulfate, as determined by IC, are assumed to 
be completely water soluble and appear only in the anion mass and charge calculations. Because oxalate was assumed to be adequately accounted for in the TOC concentration, it was not included separately in the mass balance. The concentrations of cationic species in Table B3-1, the anionic species in Table B3-2, and the percent water were ultimately used to calculate the mass balance.

The mass balance was calculated from the formula below. The factor 0.0001 is the conversion factor from $\mu \mathrm{g} / \mathrm{g}$ to weight percent.

Mass balance $\quad=\quad$ Percent water $+0.0001 \times$ TTotal Analyte Concentration\}

$$
\begin{aligned}
& =\text { Percent water }+0.0001 \times\left\{\mathrm{Cr}(\mathrm{OH})_{3}+\mathrm{Na}^{+}+\mathrm{AlO}_{2}^{-}+\mathrm{CO}_{3}^{2-}+\mathrm{C}_{2} \mathrm{H}_{3} \mathrm{O}_{2}^{-}+\right. \\
& \left.\mathrm{Cl}^{-}+\mathrm{NO}_{3}^{-}+\mathrm{NO}_{2}^{-}+\mathrm{PO}_{4}{ }^{3-}+\mathrm{SO}_{4}{ }^{2-}\right\}
\end{aligned}
$$

The total analyte concentrations calculated from the above equation is $652,000 \mu \mathrm{g} / \mathrm{g}$. The mean weight percent water is 39.8 percent or $398,000 \mu \mathrm{g} / \mathrm{g}$. The mass balance resulting from adding the percent water to the total analyte concentration is 105 percent (see Table B3-3).

The following equations demonstrate the derivation of total cations and total anions; the charge balance is the ratio of these two values.

Total cations $(\mu \mathrm{eq} / \mathrm{g})=\left[\mathrm{Na}^{+}\right] / 23.0=8,130 \mu \mathrm{eq} / \mathrm{g}$

Total anions $(\mu \mathrm{eq} / \mathrm{g})=\left[\mathrm{AlO}_{2}{ }^{-}\right] / 59.0+\left[\mathrm{CO}_{3}{ }^{2-}\right] / 30.0+\left[\mathrm{C}_{2} \mathrm{H}_{3} \mathrm{O}_{2}{ }^{-}\right] / 59.0+\left[\mathrm{Cl}^{-}\right] / 35.4+$ $\left[\mathrm{NO}_{3}{ }^{-}\right] / 62.0+\left[\mathrm{NO}_{2}^{-}\right] / 46.0+\left[\mathrm{PO}_{4}{ }^{3-}\right] / 31.7+\left[\mathrm{SO}_{4}{ }^{2-}\right] / 48.1=$ $8,520 \mu \mathrm{eq} / \mathrm{g}$

The charge balance obtained by dividing the sum of the positive charge by the sum of the negative charge was 0.95 . There is a net negative charge of $390 \mu \mathrm{eq} / \mathrm{g}$.

In summary, the above calculations yield reasonable mass and charge balance values (close to 1.00 for charge balance and 100 percent for mass balance), indicating that the analytical results are generally self-consistent.

\begin{tabular}{|c|c|c|c|c|}
\hline (1) & Concentration. & $\begin{array}{l}\text { Assunied } \\
\text { Species }\end{array}$ & 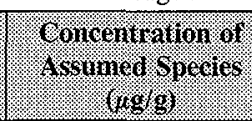 & $\begin{array}{l}\text { charge } \\
\text { (realg) }\end{array}$ \\
\hline Chromium & 3,790 & $\mathrm{Cr}(\mathrm{OH})_{3}$ & 7,510 & 0 \\
\hline Sodium & $1.87 \mathrm{E}+05$ & $\mathrm{Na}^{+}$ & $1.87 \mathrm{E}+05$ & 8,130 \\
\hline Total & & & $1.95 \mathrm{E}+05$ & 8,130 \\
\hline
\end{tabular}

Table B3-1. Sludge Cation Mass and Charge Data. 
Table B3-2. Sludge Anion Mass and Charge Data.

\begin{tabular}{|c|c|c|c|c|}
\hline 1naule & 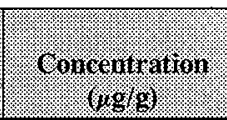 & $\begin{array}{l}\text { Asrumied } \\
\text { Speries }\end{array}$ & 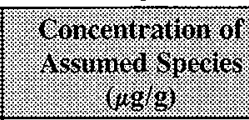 & 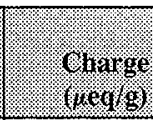 \\
\hline Aluminum & 19,600 & $\mathrm{AlO}_{2}^{-}$ & 42,800 & 726 \\
\hline TIC & 4,440 & $\mathrm{CO}_{3}^{2-}$ & 22,200 & 740 \\
\hline TOC & 3,570 & $\mathrm{C}_{2} \mathrm{H}_{3} \mathrm{O}_{2}^{-}$ & 8,780 & 149 \\
\hline Chloride & 6,550 & $\mathrm{Cl}^{-}$ & 6,550 & 185 \\
\hline Nitrate & $2.86 \mathrm{E}+05$ & $\mathrm{NO}_{3}^{-}$ & $2.86 \mathrm{E}+05$ & 4,610 \\
\hline Nitrite & 71,700 & $\mathrm{NO}_{2}^{-}$ & 71,700 & 1,560 \\
\hline Phosphate & 13,900 & $\mathrm{PO}_{4}^{3-}$ & 13,900 & 439 \\
\hline Sulfate & 5,390 & $\mathrm{SO}_{4}^{2-}$ & 5,390 & 112 \\
\hline \multicolumn{3}{|l|}{ Total } & $4.57 \mathrm{E}+05$ & 8,521 \\
\hline
\end{tabular}

Table B3-3. Sludge Mass and Charge Balance Totals.

\begin{tabular}{|l|l|l|l|}
\hline & \multicolumn{1}{|c|}{ (oncentrations: } & \multicolumn{1}{|c|}{ (rarge } \\
\hline Total from Table B3-2 (cations) & $1.95 \mathrm{E}+05$ & 8,130 \\
\hline Total from Table B3-3 (anions) & $4.57 \mathrm{E}+05$ & 8,520 \\
\hline Water percent & $3.98 \mathrm{E}+05$ & 0 \\
\hline Total & $1.05 \mathrm{E}+05$ & -390 \\
\hline
\end{tabular}

B3.3.2.2 Supernatant Mass and Charge Balance. In calculating the mass and charge balances for the supernatant layer, only those analytes listed in Table 3-8 that were detected at a concentration of $1,000 \mu \mathrm{g} / \mathrm{g}$ or greater were considered. All analytical results were first converted from $\mu \mathrm{g} / \mathrm{mL}$ to $\mu \mathrm{g} / \mathrm{g}$ (using the supernatant specific gravity mean of 1.42) before use in the tables. Because this portion of the tank is supernatant, the cations listed in Table B3-4 and the anions listed in Table B3-5 were all assumed to be present as ions, with the exception of aluminum. Aluminum is assumed to be present as aluminate. The carbonate data were derived from the TIC analyses. The acetate data were derived from the TOC analyses. Phosphate and sulfate, as determined by IC, are assumed to be completely water soluble and appear only in the anion mass and charge calculations. The concentrations of cationic species in Table B3-4, the anionic species in Table B3-5, and the percent water were ultimately used to calculate the mass balance. 
The mass balance was calculated from the formula below. The factor 0.0001 is the conversion factor from $\mu \mathrm{g} / \mathrm{g}$ to weight percent.

Mass balance $\quad=\quad$ Percent water $+0.0001 \times$ \{Total Analyte Concentration $\}$

$$
\begin{aligned}
= & \text { Percent water }+0.0001 \times\left\{\mathrm{K}^{+}+\mathrm{Na}^{+}+\mathrm{AlO}_{2}^{-}+\mathrm{CO}_{3}{ }^{2-}+\mathrm{C}_{2} \mathrm{H}_{3} \mathrm{O}_{2}{ }^{-}\right. \\
& \left.+\mathrm{Cl}^{-}+\mathrm{NO}_{3}{ }^{-}+\mathrm{NO}_{2}{ }^{-}+\mathrm{PO}_{4}{ }^{3-}+\mathrm{SO}_{4}{ }^{2-}\right\}
\end{aligned}
$$

The total analyte concentrations calculated from the above equation is $492,000 \mu \mathrm{g} / \mathrm{g}$. The mean weight percent water is 47.6 percent or $476,000 \mu \mathrm{g} / \mathrm{g}$. The mass balance resulting from adding the percent water to the total analyte concentration is 96.8 percent (see Table B3-6).

The following equations demonstrate the derivation of total cations and total anions; the charge balance is the ratio of these two values.

Total cations $(\mu \mathrm{eq} / \mathrm{g})=\left[\mathrm{K}^{+}\right] / 39.1+\left[\mathrm{Na}^{+}\right] / 23.0=7,570 \mu \mathrm{eq} / \mathrm{g}$

Total anions $(\mu \mathrm{eq} / \mathrm{g})=\left[\mathrm{AlO}_{2}^{-}\right] / 59.0+\left[\mathrm{CO}_{3}{ }^{2-}\right] / 30.0+\left[\mathrm{C}_{2} \mathrm{H}_{3} \mathrm{O}_{2}^{-}\right] / 59.0+\left[\mathrm{Cl}^{-}\right] / 35.4+$ $\left[\mathrm{NO}_{3}{ }^{-}\right] / 62.0+\left[\mathrm{NO}_{2}^{-}\right] / 46.0+\left[\mathrm{PO}_{4}{ }^{3-}\right] / 31.7+\left[\mathrm{SO}_{4}^{2-}\right] / 48.1=$ $6,140 \mu \mathrm{eq} / \mathrm{g}$

The charge balance obtained by dividing the sum of the positive charge by the sum of the negative charge was 1.23. This is a net positive charge of $1,430 \mu \mathrm{eq} / \mathrm{g}$. Assuming that this net positive charge is a result of the omission of hydroxide, this would equate to $24,400 \mu \mathrm{g} / \mathrm{g}$ of hydroxide in the supernatant. The corrected mass balance with the inclusion of hydroxide is 99.2 percent.

In summary, the above calculations and assumptions yield reasonable mass and charge balance values (close to 1.00 for charge balance and 100 percent for mass balance), indicating that the analytical results are generally self-consistent.

\begin{tabular}{|c|c|c|c|c|}
\hline dinalyte & Concentration & A Assumitid: & 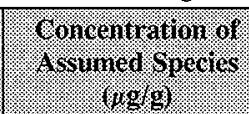 & $\begin{array}{l}\text { Charge } \\
\text { (1eurg) }\end{array}$ \\
\hline Potassium & 2,740 & $\mathrm{~K}^{+}$ & 2,740 & 70 \\
\hline Sodium & $1.72 \mathrm{E}+05$ & $\mathrm{Na}^{+}$ & $1.72 \mathrm{E}+05$ & 7,500 \\
\hline Total & & & $1.75 \mathrm{E}+05$ & 7,570 \\
\hline
\end{tabular}

Table B3-4. Supernatant Cation Mass and Charge Data. 
Table B3-5. Supernatant Anion Mass and Charge Data.

\begin{tabular}{|c|c|c|c|c|}
\hline . & Concemination & $\begin{array}{l}\text { Assomed } \\
\text { Spleies. }\end{array}$ & 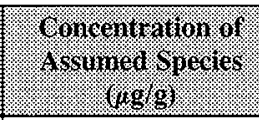 & 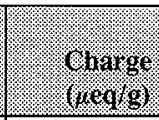 \\
\hline Aluminum & 18,200 & $\mathrm{AlO}_{2}^{-}$ & 39,900 & 676 \\
\hline TIC & 3,610 & $\mathrm{CO}_{3}^{2-}$ & 18,000 & 601 \\
\hline TOC & 2,850 & $\mathrm{C}_{2} \mathrm{H}_{3} \mathrm{O}_{2}^{-}$ & 7,010 & 119 \\
\hline Chloride & 8,240 & $\mathrm{Cl}^{-}$ & 8,240 & 233 \\
\hline Nitrate & $1.46 \mathrm{E}+05$ & $\mathrm{NO}_{3}^{-}$ & $1.46 \mathrm{E}+05$ & 2,350 \\
\hline Nitrite & 92,200 & $\mathrm{NO}_{2}^{-}$ & 92,200 & 2,010 \\
\hline Phosphate & 2,270 & $\mathrm{PO}_{4}{ }^{3-}$ & 2,270 & 72 \\
\hline Sulfate & 3,810 & $\mathrm{SO}_{4}{ }^{2-}$ & 3,810 & 79 \\
\hline Total & & & $3.17 \mathrm{E}+05$ & 6,140 \\
\hline
\end{tabular}

Table B3-6. Supernatant Mass and Charge Balance Totals.

\begin{tabular}{|c|c|c|}
\hline 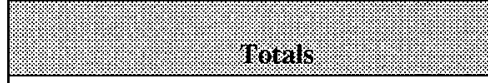 & 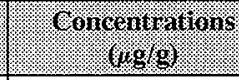 & 1:0: \\
\hline Total from Table B3-4 (cations) & $1.75 \mathrm{E}+05$ & 7,570 \\
\hline Total from Table B3-5 (anions) & $3.17 \mathrm{E}+05$ & 6,140 \\
\hline Water percent & $4.76 \mathrm{E}+05$ & 0 \\
\hline Subtotal & $9.68 \mathrm{E}+05$ & $+1,430$ \\
\hline Hydroxide assumed from charge balance & 24,300 & $-1,430$ \\
\hline Total & $9.92 \mathrm{E}+05$ & 0 \\
\hline
\end{tabular}

\section{B3.4 MEAN CONCENTRATIONS AND CONFIDENCE INTERVALS}

\section{B3.4.1 Solid Data}

A nested analysis of variance (ANOVA) model was fit to the core segment data. Mean values, and 95 percent confidence intervals on the mean, were determined from the ANOVA. Four variance components were used in the calculations. The variance components represent concentration differences between risers, segments, laboratory samples, and analytical replicates. The model is: 


$$
\begin{gathered}
\mathrm{Y}_{\mathrm{ijk}}=\mu+\mathrm{R}_{\mathrm{i}}+\mathrm{S}_{\mathrm{ij}}+\mathrm{L}_{\mathrm{ijk}}+\mathrm{A}_{\mathrm{ijkm}}, \\
\mathrm{I}=1,2, \ldots, \mathrm{a} ; \mathrm{j}=1,2, \ldots, \mathrm{b}_{\mathrm{i}} ; \mathrm{k}=1,2, \ldots, \mathrm{c}_{\mathrm{ij}} ; \mathrm{m}=1,2, \ldots, \mathrm{n}_{\mathrm{ijk}}
\end{gathered}
$$

where:

$$
\begin{aligned}
& Y_{\mathrm{ijk}}=\text { concentration from the } \mathrm{m}^{\text {th }} \text { analytical result of the } \mathrm{k}^{\mathrm{th}} \text { sample of the } \mathrm{j}^{\text {th }} \\
& \text { segment of the } \mathrm{i}^{\text {th }} \text { riser } \\
& \mu \quad=\text { the mean } \\
& R_{i}=\text { the effect of the } i^{\text {th }} \text { riser } \\
& S_{i j}=\text { the effect of the } \mathrm{j}^{\text {th }} \text { segment from the } \mathrm{i}^{\text {th }} \text { riser } \\
& L_{\mathrm{ijk}}=\text { the effect of the } \mathrm{k}^{\text {th }} \text { sample from the } \mathrm{j}^{\text {th }} \text { segment of the } \mathrm{i}^{\text {th }} \text { riser } \\
& \mathrm{A}_{\mathrm{ijkm}}=\text { the analytical error } \\
& \mathrm{a}=\text { the number of risers } \\
& b_{i}=\text { the number of segments from the } i^{\text {th }} \text { riser } \\
& c_{i j}=\text { the number of samples from the } j^{\text {th }} \text { segment of the } i^{\text {it }} \text { riser } \\
& n_{i j k}=\text { the number of analytical results from the } i \mathrm{jk}^{\text {th }} \text { sample. }
\end{aligned}
$$

The variables $R_{i}, S_{i j}$, and $L_{i j k}$ are random effects. These variables, as well as $A_{i j k m}$, are assumed to be uncorrelated and normally distributed with means zero and variances $\sigma^{2}(R)$, $\sigma^{2}(S), \sigma^{2}(L)$ and $\sigma^{2}(A)$, respectively.

The restricted maximum likelihood method (REML) was used to estimate the mean concentration and standard deviation of the mean for all analytes that had 50 percent or more of their reported values greater than the detection limit. The mean value and standard deviation of the mean were used to calculate the 95 percent confidence intervals. Table B3-7 gives the mean, 'degrees of freedom, and confidence interval for each constituent. The statistical results were obtained using the statistical analysis package S-PLUS ${ }^{1}$ (Statistical Sciences 1993).

\footnotetext{
${ }^{1}$ S-PLUS is a registered trademark of Statistical Sciences, Seattle, Washington.
} 
A $300-\mathrm{mL}$ solution of isotopically labeled ammonium hydroxide was added to the RGS waste samples to aid in ammonia determination. Because this additional liquid in the samples may bias the analytical results, the results from the RGS samples. were not included in the derivation of the statistical means.

Some analytes had results that were below the detection limit. In these cases the value of the detection limit was used for nondetected results. For analytes with a majority of results below the detection limit, a simple average is all that is reported. For those analytes with less-than values, including the detection limit in the computation of the mean may bias the result high.

The lower and upper limits, LL(95\%) and UL(95\%), of a two-sided 95 percent confidence interval on the mean were calculated using the following equation:

$$
\begin{aligned}
\mathrm{LL}(95 \%) & =\hat{\mu}-\mathrm{t}_{(\mathrm{df}, 0.025)} \times \hat{\sigma}(\hat{\mu}), \\
\mathrm{UL}(95 \%) & =\hat{\mu}+\mathrm{t}_{(\mathrm{df}, 0.025)} \times \hat{\sigma}(\hat{\mu}) .
\end{aligned}
$$

In this equation, $\hat{\mu}$ is the restricted maximum likelihood method estimate of the mean concentration, $\hat{\sigma}(\hat{\mu})$ is the restricted maximum likelihood method estimate of the standard deviation of the mean, and $\mathrm{t}_{(\mathrm{df}, 0.025)}$ is the quantile from Student's $t$ distribution with $d f$ degrees of freedom. The degrees of freedom equals the number of risers with data minus one. In cases where the lower limit of the confidence interval was negative, it is reported as zero.

Table B3-7. Tank 241-SX-106 95 Percent Two-Sided Confidence Interval for the Mean Concentration for Solid Segment Data. (3 sheets)

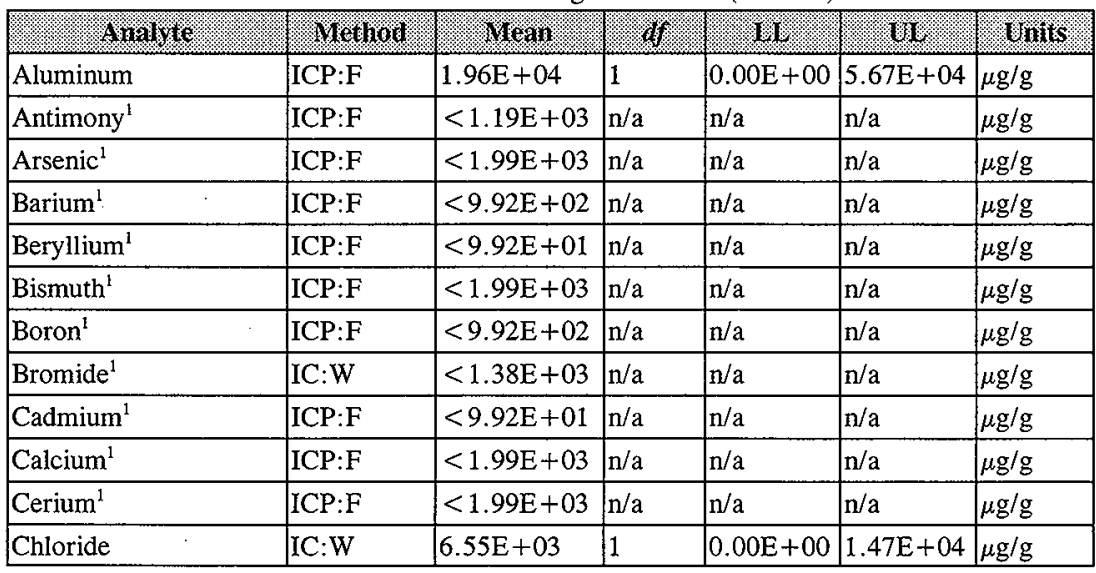


Table B3-7. Tank 241-SX-106 95 Percent Two-Sided Confidence Interval for the Mean Concentration for Solid Segment Data. (3 sheets)

\begin{tabular}{|c|c|c|c|c|c|c|}
\hline 4rialyte & Metrous & Hean & . & 1.1. & 1.: & Uniss. \\
\hline Chromium $^{1}$ & ICP:F & $3.79 \mathrm{E}+03$ & 1 & $0.00 \mathrm{E}+00$ & $1.73 \mathrm{E}+04$ & $\mu \mathrm{g} / \mathrm{g}$ \\
\hline Cobalt $^{1}$ & ICP:F & $<3.97 \mathrm{E}+02$ & $n / a$ & $\mathrm{n} / \mathrm{a}$ & $n / a$ & $\mu \mathrm{g} / \mathrm{g}$ \\
\hline Copper $^{1}$ & ICP:F & $<1.99 \mathrm{E}+02$ & $\mathrm{n} / \mathrm{a}$ & $\mathrm{n} / \mathrm{a}$ & $\mathrm{n} / \mathrm{a}$ & $\mu \mathrm{g} / \mathrm{g}$ \\
\hline Fluoride ${ }^{1}$ & IC:W & $5.30 \mathrm{E}+02$ & 1 & $0.00 \mathrm{E}+00$ & $3.48 \mathrm{E}+03$ & $\mu \mathrm{g} / \mathrm{g}$ \\
\hline Gross alpha $^{1}$ & Alpha:F & $2.88 \mathrm{E}-01$ & 1 & $0.00 \mathrm{E}+00$ & $2.22 \mathrm{E}+00$ & $\mu \mathrm{Ci} / \mathrm{g}$ \\
\hline Iron $^{1}$ & ICP:F & $<1.23 \mathrm{E}+03$ & $\mathrm{n} / \mathrm{a}$ & $n / a$ & $\mathrm{n} / \mathrm{a}$ & $\mu \mathrm{g} / \mathrm{g}$ \\
\hline Lanthanum $^{1}$ & ICP:F & $<9.92 \mathrm{E}+02$ & $\mathrm{n} / \mathrm{a}$ & $\mathrm{n} / \mathrm{a}$ & $\mathrm{n} / \mathrm{a}$ & $\mu \mathrm{g} / \mathrm{g}$ \\
\hline Lead $^{1}$ & ICP:F & $<1.99 \mathrm{E}+03$ & $\mathrm{n} / \mathrm{a}$ & $\mathrm{n} / \mathrm{a}$ & $\mathrm{n} / \mathrm{a}$ & $\mu \mathrm{g} / \mathrm{g}$ \\
\hline Lithium $^{1}$ & ICP:F & $<1.99 \mathrm{E}+02$ & $n / a$ & $\mathrm{n} / \mathrm{a}$ & $\mathrm{n} / \mathrm{a}$ & $\mu \mathrm{g} / \mathrm{g}$ \\
\hline Magnesium ${ }^{1}$ & ICP:F & $<1.99 \mathrm{E}+03$ & $\mathrm{n} / \mathrm{a}$ & $\mathrm{n} / \mathrm{a}$ & $n / a$ & $\mu \mathrm{g} / \mathrm{g}$ \\
\hline Manganese $^{1}$ & ICP:F & $3.56 \mathrm{E}+02$ & 1 & $0.00 \mathrm{E}+00$ & $1.71 \mathrm{E}+03$ & $\mu \mathrm{g} / \mathrm{g}$ \\
\hline Molybdenum $^{1}$ & ICP:F & $<9.92 \mathrm{E}+02$ & $n / a$ & $\mathrm{n} / \mathrm{a}$ & $\mathrm{n} / \mathrm{a}$ & $\mu \mathrm{g} / \mathrm{g}$ \\
\hline Neodymium $^{l}$ & ICP:F & $<1.99 \mathrm{E}+03$ & $n / a$ & $\mathrm{n} / \mathrm{a}$ & $\mathrm{n} / \mathrm{a}$ & $\mu \mathrm{g} / \mathrm{g}$ \\
\hline Nitrate $^{1}$ & $\mathrm{IC}: \mathrm{W}$ & $2.86 \mathrm{E}+05$ & 1 & $0.00 \mathrm{E}+00$ & $1.35 \mathrm{E}+06$ & $\mu \mathrm{g} / \mathrm{g}$ \\
\hline Nitrite & IC:W & $7.17 \mathrm{E}+04$ & 1 & $0.00 \mathrm{E}+00$ & $1.65 \mathrm{E}+05$ & $\mu \mathrm{g} / \mathrm{g}$ \\
\hline Oxalate $^{1}$ & IC:W & $6.44 E+03$ & 1 & $0.00 \mathrm{E}+00$ & $2.34 \mathrm{E}+04$ & $\mu \mathrm{g} / \mathrm{g}$ \\
\hline Percent water & DSC/TGA & $3.98 \mathrm{E}+01$ & 1 & $1.30 \mathrm{E}+01$ & $6.66 \mathrm{E}+01$ & $\%$ \\
\hline Phosphate & IC:W & $1.39 \mathrm{E}+04$ & 1 & $0.00 \mathrm{E}+00$ & $3.62 \mathrm{E}+04$ & $\mu \mathrm{g} / \mathrm{g}$ \\
\hline Phosphorus $^{1}$ & ICP:F & $<5.06 \mathrm{E}+03$ & $\mathrm{n} / \mathrm{a}$ & $\mathrm{n} / \mathrm{a}$ & $\mathrm{n} / \mathrm{a}$ & $\mu \mathrm{g} / \mathrm{g}$ \\
\hline Samarium $^{1}$ & ICP:F & $<1.99 \mathrm{E}+03$ & $\mathrm{n} / \mathrm{a}$ & $\mathrm{n} / \mathrm{a}$ & $n / a$ & $\mu \mathrm{g} / \mathrm{g}$ \\
\hline Silicon $^{1}$ & ICP:F & $<1.06 \mathrm{E}+03$ & $\mathrm{n} / \mathrm{a}$ & $\mathrm{n} / \mathrm{a}$ & $n / a$ & $\mu \mathrm{g} / \mathrm{g}$ \\
\hline Silver ${ }^{l}$ & ICP:F & $<1.99 \mathrm{E}+02$ & $\mathrm{n} / \mathrm{a}$ & $\mathrm{n} / \mathrm{a}$ & $n / a$ & $\mu \mathrm{g} / \mathrm{g}$ \\
\hline Sodium & ICP:F & $1.87 \mathrm{E}+05$ & 1 & $1.22 \mathrm{E}+05$ & $2.52 \mathrm{E}+05$ & $\mu \mathrm{g} / \mathrm{g}$ \\
\hline Strontium $^{1}$ & ICP:F & $<1.99 \mathrm{E}+02$ & $\mathrm{n} / \mathrm{a}$ & $\mathrm{n} / \mathrm{a}$ & $\mathrm{n} / \mathrm{a}$ & $\mu \mathrm{g} / \mathrm{g}$ \\
\hline Sulfate $^{1}$ & IC:W & $5.39 \mathrm{E}+03$ & 1 & $0.00 \mathrm{E}+00$ & $1.90 \mathrm{E}+04$ & $\mu \mathrm{g} / \mathrm{g}$ \\
\hline Sulfur ${ }^{1}$ & ICP:F & $<2.22 \mathrm{E}+03$ & $\mathrm{n} / \mathrm{a}$ & $\mathrm{n} / \mathrm{a}$ & $\mathrm{n} / \mathrm{a}$ & $\mu \mathrm{g} / \mathrm{g}$ \\
\hline Thallium $^{1}$ & ICP:F & $<3.97 \mathrm{E}+03$ & $\mathrm{n} / \mathrm{a}$ & $n / a$ & $\mathrm{n} / \mathrm{a}$ & $\mu \mathrm{g} / \mathrm{g}$ \\
\hline Titanium $^{1}$ & ICP:F & $<1.99 \mathrm{E}+02$ & $n / a$ & $\mathrm{n} / \mathrm{a}$ & $\mathrm{n} / \mathrm{a}$ & $\mu \mathrm{g} / \mathrm{g}$ \\
\hline TIC & TIC/TOC & $4.44 \mathrm{E}+03$ & 1 & $0.00 \mathrm{E}+00$ & $1.26 \mathrm{E}+04$ & $\mu \mathrm{g} / \mathrm{g}$ \\
\hline TOC & TIC/TOC & $3.57 \mathrm{E}+03$ & 1 & $0.00 \mathrm{E}+00$ & $7.98 \mathrm{E}+03$ & $\mu \mathrm{g} / \mathrm{g}$ \\
\hline
\end{tabular}


Table B3-7. Tank 241-SX-106 95 Percent Two-Sided Confidence Interval for the Mean Concentration for Solid Segment Data. (3 sheets)

\begin{tabular}{|c|c|c|c|c|c|c|}
\hline Ansilte & Method: & Mean & (if) & 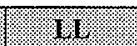 & U1: & Units. \\
\hline TOC & $\begin{array}{l}\text { Furnace } \\
\text { oxidation }\end{array}$ & $7.73 \mathrm{E}+03$ & 1 & $0.00 \mathrm{E}+00$ & $2.04 \mathrm{E}+04$ & $\mu \mathrm{g} / \mathrm{g}$ \\
\hline Uranium $^{1}$ & ICP:F & $<9.92 \mathrm{E}+03$ & $n / a$ & $n / a$ & $n / a$ & $\mu \mathrm{g} / \mathrm{g}$ \\
\hline Vanadium $^{1}$ & ICP:F & $<9.92 \mathrm{E}+02$ & $n / a$ & $n / a$ & $n / a$ & $\mu \mathrm{g} / \mathrm{g}$ \\
\hline Zinc $^{1}$ & ICP:F & $<1.99 \mathrm{E}+02$ & $n / a$ & $n / a$ & n/a & $\mu \mathrm{g} / \mathrm{g}$ \\
\hline Zirconium $^{1}$ & ICP:F & $<1.99 \mathrm{E}+02$ & $n / a$ & $\mathrm{n} / \mathrm{a}$ & $\mathrm{n} / \mathrm{a}$ & $\mu \mathrm{g} / \mathrm{g}$ \\
\hline
\end{tabular}

Note:

'A "less than" value was used in the calculation.

\section{B3.4.2 Liquid Data}

The model fit to the liquid data was a nested ANOVA model. The model determined the mean value, and 95 percent confidence interval, for each constituent. Two variance components were used in the calculations. The variance components represent concentration differences between samples taken from different riser and between analytical replicates. The model is:

where

$$
\begin{gathered}
Y_{i j k}=\mu+R_{i}+A_{i j}, \\
I=1,2, \ldots, a ; j=1,2, \ldots, n_{i} ;
\end{gathered}
$$

$$
\begin{aligned}
& \mathrm{Y}_{\mathrm{ijk}}=\text { concentration from the } \mathrm{k}^{\mathrm{th}} \text { analytical result of the } \mathrm{j}^{\mathrm{th}} \text { sample from the } \mathrm{i}^{\text {th }} \\
& \mu \quad=\text { the mean } \\
& \mathrm{R}_{\mathrm{i}}=\text { the effect of the } \mathrm{i}^{\text {th }} \text { riser } \\
& \mathrm{A}_{\mathrm{ij}}=\text { the analytical error } \\
& \mathrm{a} \quad=\text { the number of segments } \\
& \mathrm{n}_{\mathrm{i}}=\text { the number of analytical results from the } \mathrm{i}^{\text {th }} \text { riser. }
\end{aligned}
$$


The variable $R_{i}$ is a random effect. This variable, along with $A_{i j}$, is assumed to be uncorrelated and normally distributed with means zero and variances $\sigma^{2}(\mathrm{R})$ and $\sigma^{2}(\mathrm{~A})$, respectively. Table B3-8 gives the mean, degrees of freedom, and confidence interval for each constituent. The degrees of freedom associated with the standard deviation of the mean is the number of risers with data minus one.

A $300-\mathrm{mL}$ solution of isotopically labeled ammonium hydroxide was added to the RGS waste samples to aid in ammonia determination. Because this additional liquid in the samples may bias the analytical results, the results from the RGS samples were not included in the derivation of the statistical means.

Table B3-8. Tank 241-SX-106 95 Percent Two-Sided Confidence Interval for the Mean Concentration for Liquid Subdivision Data. (2 sheets)

\begin{tabular}{|c|c|c|c|c|c|c|}
\hline arayte & Hen1100 & mear & 16 & y) & . & (binds \\
\hline Aluminum & ICP & $2.59 \mathrm{E}+04$ & 1 & $1.94 \mathrm{E}+04$ & $3.24 \mathrm{E}+04$ & $\mu \mathrm{g} / \mathrm{mL}$ \\
\hline Antimony ${ }^{1}$ & ICP & $<3.61 E+01$ & $\mathrm{n} / \mathrm{a}$ & n/a & $\mathrm{n} / \mathrm{a}$ & $\mu \mathrm{g} / \mathrm{mL}$ \\
\hline Arsenic $^{k}$ & $\mathrm{ICP}$ & $<6.01 \mathrm{E}+01$ & $n / a$ & $\mathrm{n} / \mathrm{a}$ & $n / a$ & $\mu \mathrm{g} / \mathrm{mL}$ \\
\hline Barium $^{1}$ & $\mathrm{ICP}$ & $<3.01 \mathrm{E}+01$ & $\mathrm{n} / \mathrm{a}$ & $n / a$ & $\mathrm{n} / \mathrm{a}$ & $\mu \mathrm{g} / \mathrm{mL}$ \\
\hline Beryllium $^{1}$ & ICP & $<3.00 \mathrm{E}+00$ & $n / a$ & $\mathrm{n} / \mathrm{a}$ & $\mathrm{n} / \mathrm{a}$ & $\mu \mathrm{g} / \mathrm{mL}$ \\
\hline Bismuth $^{\mathrm{I}}$ & $\mathrm{ICP}$ & $<6.01 \mathrm{E}+01$ & $\mathrm{n} / \mathrm{a}$ & $\mathrm{n} / \mathrm{a}$ & $\mathrm{n} / \mathrm{a}$ & $\mu \mathrm{g} / \mathrm{mL}$ \\
\hline Boron & ICP & $9.34 \mathrm{E}+01$ & 1 & $7.57 \mathrm{E}+01$ & $1.11 \mathrm{E}+02$ & $\mu \mathrm{g} / \mathrm{mL}$ \\
\hline Bromide $^{1}$ & IC & $1.03 \mathrm{E}+03$ & 1 & $0.00 E+00$ & $2.46 \mathrm{E}+03$ & $\mu \mathrm{g} / \mathrm{mL}$ \\
\hline Cadmium $^{1}$ & ICP & $<3.00 \mathrm{E}+00$ & $\mathrm{n} / \mathrm{a}$ & $n / a$ & $\mathrm{n} / \mathrm{a}$ & $\mu \mathrm{g} / \mathrm{mL}$ \\
\hline Calcium $^{1}$ & $\mathrm{ICP}$ & $<6.01 \mathrm{E}+01$ & $\mathrm{n} / \mathrm{a}$ & $\mathrm{n} / \mathrm{a}$ & $\mathrm{n} / \mathrm{a}$ & $\mu \mathrm{g} / \mathrm{mL}$ \\
\hline Cerium $^{1}$ & $\mathrm{ICP}$ & $<6.01 \mathrm{E}+01$ & $\mathrm{n} / \mathrm{a}$ & $\mathrm{n} / \mathrm{a}$ & $\mathrm{n} / \mathrm{a}$ & $\mu \mathrm{g} / \mathrm{mL}$ \\
\hline Chloride & IC & $1.17 \mathrm{E}+04$ & 1 & $9.30 \mathrm{E}+03$ & $1.42 \mathrm{E}+04$ & $\mu \mathrm{g} / \mathrm{mL}$ \\
\hline Chromium & ICP & $1.29 \mathrm{E}+02$ & 1 & $8.55 \mathrm{E}+01$ & $1.73 E+02$ & $\mu \mathrm{g} / \mathrm{mL}$ \\
\hline Cobalt $^{1}$ & $\mathrm{ICP}$ & $<1.20 \mathrm{E}+01$ & $n / a$ & $n / a$ & $\mathrm{n} / \mathrm{a}$ & $\mu \mathrm{g} / \mathrm{mL}$ \\
\hline Copper ${ }^{1}$ & ICP & $<6.01 \mathrm{E}+00$ & $\mathrm{n} / \mathrm{a}$ & $\mathrm{n} / \mathrm{a}$ & $\mathrm{n} / \mathrm{a}$ & $\mu \mathrm{g} / \mathrm{mL}$ \\
\hline Fluoride $^{1}$ & IC & $3.11 \mathrm{E}+02$ & 1 & $0.00 \mathrm{E}+00$ & $1.33 E+03$ & $\mu \mathrm{g} / \mathrm{mL}$ \\
\hline Gross alpha $^{1}$ & Alpha & $<3.64 \mathrm{E}-03$ & $\mathrm{n} / \mathrm{a}$ & $\mathrm{n} / \mathrm{a}$ & $n / a$ & $\mu \mathrm{Ci} / \mathrm{mL}$ \\
\hline Iron $^{1}$ & ICP & $<3.01 \mathrm{E}+01$ & $\mathrm{n} / \mathrm{a}$ & $n / a$ & $n / a$ & $\mu \mathrm{g} / \mathrm{mL}$ \\
\hline Lanthanum $^{1}$ & ICP & $<3.01 \mathrm{E}+01$ & $\mathrm{n} / \mathrm{a}$ & $n / a$ & $\mathrm{n} / \mathrm{a}$ & $\mu \mathrm{g} / \mathrm{mL}$ \\
\hline Lead $^{1}$ & ICP & $<6.01 \mathrm{E}+01$ & $n / a$ & $\mathrm{n} / \mathrm{a}$ & $\mathrm{n} / \mathrm{a}$ & $\mu \mathrm{g} / \mathrm{mL}$ \\
\hline Lithium $^{1}$ & $\mathrm{ICP}$ & $8.07 \mathrm{E}+00$ & 1 & $0.00 \mathrm{E}+00$ & $2.47 \mathrm{E}+01$ & $\mu \mathrm{g} / \mathrm{mL}$ \\
\hline Magnesium ${ }^{1}$ & ICP & $<6.01 \mathrm{E}+01$ & $\mathrm{n} / \mathrm{a}$ & $n / a$ & $n / a$ & $\mu \mathrm{g} / \mathrm{mL}$ \\
\hline
\end{tabular}


Table B3-8. Tank 241-SX-106 95 Percent Two-Sided Confidence Interval for the Mean Concentration for Liquid Subdivision Data. (2 sheets)

\begin{tabular}{|c|c|c|c|c|c|c|}
\hline W. & Melnod & Moan & 6 & Yy & 8 & yilis \\
\hline Manganese & $\mathrm{ICP}$ & $<6.01 E+00$ & $\mathrm{n} / \mathrm{a}$ & $\mathrm{n} / \mathrm{a}$ & $\mathrm{n} / \mathrm{a}$ & $\mu \mathrm{g} / \mathrm{mL}$ \\
\hline Molybdenum & $\mathrm{ICP}$ & $1.27 \mathrm{E}+02$ & 1 & $1.06 \mathrm{E}+02$ & $1.48 \mathrm{E}+02$ & $\mu \mathrm{g} / \mathrm{mL}$ \\
\hline Neodymium $^{1}$ & ICP & $<6.01 \mathrm{E}+01$ & $\mathrm{n} / \mathrm{a}$ & $\mathrm{n} / \mathrm{a}$ & $\mathrm{n} / \mathrm{a}$ & $\mu \mathrm{g} / \mathrm{mL}$ \\
\hline Nickel $^{1}$ & $\mathrm{ICP}$ & $<1.20 \mathrm{E}+01$ & $\mathrm{n} / \mathrm{a}$ & $\mathrm{n} / \mathrm{a}$ & $\mathrm{n} / \mathrm{a}$ & $\mu \mathrm{g} / \mathrm{mL}$ \\
\hline Nitrate & IC & $2.07 \mathrm{E}+05$ & 1 & $3.86 \mathrm{E}+04$ & $3.75 \mathrm{E}+05$ & $\mu \mathrm{g} / \mathrm{mL}$ \\
\hline Nitrite & $\mathrm{IC}$ & $1.31 \mathrm{E}+05$ & 1 & $7.96 \mathrm{E}+04$ & $1.83 \mathrm{E}+05$ & $\mu \mathrm{g} / \mathrm{mL}$ \\
\hline Oxalate $^{1}$ & IC & $<7.75 \mathrm{E}+02$ & $\mathrm{n} / \mathrm{a}$ & $\mathrm{n} / \mathrm{a}$ & $\mathrm{n} / \mathrm{a}$ & $\mu \mathrm{g} / \mathrm{mL}$ \\
\hline Percent $\mathrm{H}_{2} \mathrm{O}$ & $\mathrm{DSC} / \mathrm{TGA}$ & $4.76 \mathrm{E}+01$ & 1 & $8.27 . E+00$ & $8.68 \mathrm{E}+01$ & $\%$ \\
\hline Phosphate & IC & $3.22 \mathrm{E}+03$ & 1 & $7.20 \mathrm{E}+02$ & $5.72 \mathrm{E}+03$ & $\mu \mathrm{g} / \mathrm{mL}$ \\
\hline Phosphorus & ICP & $1.15 \mathrm{E}+03$ & 1 & $4.75 \mathrm{E}+02$ & $1.82 \mathrm{E}+03$ & $\mu \mathrm{g} / \mathrm{mL}$ \\
\hline Potassium & ICP & $3.89 E+03$ & 1 & $3.14 \mathrm{E}+03$ & $4.65 \mathrm{E}+03$ & $\mu \mathrm{g} / \mathrm{mL}$ \\
\hline Samarium $^{1}$ & ICP & $<6.01 \mathrm{E}+01$ & $\mathrm{n} / \mathrm{a}$ & $\mathrm{n} / \mathrm{a}$ & $\mathrm{n} / \mathrm{a}$ & $\mu \mathrm{g} / \mathrm{mL}$ \\
\hline Silicon & $\mathrm{ICP}$ & $8.57 \mathrm{E}+01$ & 1 & $0.00 \mathrm{E}+00$ & $4.33 E+02$ & $\mu \mathrm{g} / \mathrm{mL}$ \\
\hline Silver & $\mathrm{ICP}$ & $1.75 \mathrm{E}+01$ & 1 & $1.34 \mathrm{E}+01$ & $2.15 \mathrm{E}+01$ & $\mu \mathrm{g} / \mathrm{mL}$ \\
\hline Sodium & ICP & $2.45 E+05$ & 1 & $1.92 \mathrm{E}+05$ & $2.98 \mathrm{E}+05$ & $\mu \mathrm{g} / \mathrm{mL}$ \\
\hline Strontium $^{1}$ & $\mathrm{ICP}$ & $<6.01 \mathrm{E}+00$ & $\mathrm{n} / \mathrm{a}$ & $\mathrm{n} / \mathrm{a}$ & $\mathrm{n} / \mathrm{a}$ & $\mu \mathrm{g} / \mathrm{mL}$ \\
\hline Sulfate & IC & $5.41 E+03$ & 1 & $3.58 \mathrm{E}+03$ & $7.24 \mathrm{E}+03$ & $\mu \mathrm{g} / \mathrm{mL}$ \\
\hline Sulfur & ICP & $2.40 \mathrm{E}+03$ & 1 & $2.02 \mathrm{E}+03$ & $2.78 \mathrm{E}+03$ & $\mu \mathrm{g} / \mathrm{mL}$ \\
\hline Thallium $^{1}$ & ICP & $<1.20 \mathrm{E}+02$ & $n / a$ & $n / a$ & $\mathrm{n} / \mathrm{a}$ & $\mu \mathrm{g} / \mathrm{mL}$ \\
\hline Titanium $^{1}$ & ICP & $<6.01 \mathrm{E}+00$ & $\mathrm{n} / \mathrm{a}$ & $n / a$ & $\mathrm{n} / \mathrm{a}$ & $\mu \mathrm{g} / \mathrm{mL}$ \\
\hline TIC & TIC/TOC & $5.12 \mathrm{E}+03$ & 1 & $4.05 E+03$ & $6.18 \mathrm{E}+03$ & $\mu \mathrm{g} / \mathrm{mL}$ \\
\hline TOC & TIC/TOC & $4.05 \mathrm{E}+03$ & 1 & $3.05 E+03$ & $5.06 \mathrm{E}+03$ & $\mu \mathrm{g} / \mathrm{mL}$ \\
\hline Uranium $^{1}$ & $\mathrm{ICP}$ & $<3.00 \mathrm{E}+02$ & $\mathrm{n} / \mathrm{a}$ & $\mathrm{n} / \mathrm{a}$ & $\mathrm{n} / \mathrm{a}$ & $\mu \mathrm{g} / \mathrm{mL}$ \\
\hline Vanadium $^{1}$ & ICP & $<3.01 \mathrm{E}+01$ & $\mathrm{n} / \mathrm{a}$ & $\mathrm{n} / \mathrm{a}$ & $\mathrm{n} / \mathrm{a}$ & $\mu \mathrm{g} / \mathrm{mL}$ \\
\hline Zinc $^{1}$ & ICP & $<6.01 \mathrm{E}+00$ & $\mathrm{n} / \mathrm{a}$ & $\mathrm{n} / \mathrm{a}$ & $\mathrm{n} / \mathrm{a}$ & $\mu \mathrm{g} / \mathrm{mL}$ \\
\hline Zirconium $^{1}$ & ICP & $<6.01 \mathrm{E}+00$ & $\mathrm{n} / \mathrm{a}$ & $\mathrm{n} / \mathrm{a}$ & $\mathrm{n} / \mathrm{a}$ & $\mu \mathrm{g} / \mathrm{mL}$ \\
\hline
\end{tabular}

Note:

'A "less than" value was used in the calculation. 


\section{B4.0 APPENDIX B REFERENCES}

Bates, J. M., 1997, Sampling Plan for Tank 241-SX-106 Retained Gas Sampler Deployment, TWSFG9772, Pacific Northwest National Laboratory, Richland, Washington.

Bauer, R. E., and L. P. Jackson, 1998, Data Quality Objective to Support Resolution of the Flammable Gas Safety Issue, HNF-SD-WM-DQO-004, Rev. 3A, DE\&S Hanford, Inc., for Fluor Daniel Hanford, Inc., Richland, Washington.

Caprio, G. S., 1995, Vapor and Gas Sampling of Single-Shell Tank 241-SX-106 Using the Vapor Sampling System, WHC-SD-WM-RPT-145, Rev. 0, Westinghouse Hanford Company, Richland, Washington.

De Lorenzo, D. S., J. H. Rutherford, D. J. Smith, D. B. Hiller, K. W. Johnson, and B. C. Simpson, 1994, Tank Characterization Reference Guide, WHC-SD-WM-TI-648, Rev. 0A, Westinghouse Hanford Company, Richland, Washington.

DOE, 1997, Hanford Analytical Services Quality Assurance Requirements Document, DOE/RL-96-68, Rev. 1, U.S. Department of Energy, Richland, Washington.

Dukelow, G. T., J. W. Hunt, H. Babad, and J. E. Meacham, 1995, Tank Safety Screening Data Quality Objective, WHC-SD-WM-SP-004, Rev. 2, Westinghouse Hanford Company, Richland, Washington.

Homi, C. S., 1995, Tank 241-SX-106 Tank Characterization Plan, WHC-SD-WM-TP-314, Rev. 0, Westinghouse Hanford Company, Richland, Washington.

Huckaby, J. L., and D. R. Bratzel, 1995, Tank 241-SX-106 Headspace Gas and Vapor Characterization Results for Samples Collected in March 1995, WHC-SD-WM-ER-460, Rev. 1, Westinghouse Hanford Company, Richland, Washington.

Jo, J., 1997, Tank 241-SX-106 Push Mode Core Sampling and Analysis Plan, HNF-SD-WM-TSAP-148, Rev. 1, Lockheed Martin Hanford Corp. for Fluor Daniel Hanford, Inc., Richland, Washington.

Mahoney, L. A., Z. I. Antoniak, and J. M. Bates, 1998, Preliminary Retained Gas Sampler Measurement Results for Hanford Waste Tank 241-SX-106, TWS98.33, Pacific Northwest National Laboratory, Richland, Washington.

Meacham, J. E., D. L. Banning, M. R. Allen, and L. D. Muhlestein, 1997, Data Quality Objective to Support Resolution of the Organic Solvent Safety Issue, HNF-SD-WM-DQO-026, Rev. 0, DE\&S Hanford, Inc. for Fluor Daniel Hanford, Inc., Richland, Washington. 
Osborne, J. W., and L. L. Buckley, 1995, Data Quality Objectives for Tank Hazardous Vapor Safety Screening, WHC-SD-WM-DQO-002, Rev. 2, Westinghouse Hanford Company, Richland, Washington.

Schreiber, R. D., 1997, Memorandum of Understanding for the Organic Complexant Safety Issue Data Requirements, HNF-SD-WM-RD-060, Rev. 0, Lockheed Martin Hanford Corp. for Fluor Daniel Hanford, Inc., Richland, Washington.

Statistical Science, 1993, S-PLUS Reference Manual, Version 3.2, Statistical Sciences, a division of MathSoft, Inc., Seattle, Washington.

Steen. F. H., 1998, Tank 241-SX-106, Cores 223 and 224, Analytical Results for the Final Report, HNF-SD-WM-DP-288, Rev. 0, Waste Management Federal Services of Hanford, Inc., for Fluor Daniel Hanford, Inc., Richland, Washington.

WHC, 1992, Safety Department Administrative Manuals, Westinghouse Hanford Company, Richland, Washington.

Whitney, P. D., G. Chen, P. A. Gauglitz, P. A. Meyer, and N. E. Miller, 1997, Estimating Retained Gas Volumes in the Hanford Waste Tanks Using Waste Level Measurements, PNNL-11693, Pacific Northwest National Laboratory, Richland, Washington.

Wilkins, N. E., R. E. Bauer, and D. M. Ogden, 1997, Results of Vapor Space Monitoring of Flammable Gas Watch List Tanks, HNF-SD-WM-TI-797, Rev. 2, Lockheed Martin Hanford Corp. for Fluor Daniel Hanford, Inc., Richland, Washington. 
HNF-SD-WM-ER-645 Rev. 1

This page intentionally left blank. 
HNF-SD-WM-ER-645 Rev. 1

APPENDIX C

STATISTICAL ANALYSIS FOR ISSUE RESOLUTION

C-1 
HNF-SD-WM-ER-645 Rev. 1

This page intentionally left blank. 


\section{APPENDIX C \\ STATISTICAL ANALYSIS FOR ISSUE RESOLUTION}

Appendix $\mathrm{C}$ documents the results of the analyses and statistical and numerical manipulations required by the DQOs applicable for tank 241-SX-106. The analyses required for tank 241-SX-106 are reported as follows:

- Section C1.0: Statistical analysis and numerical manipulations supporting the safety screening DQO (Dukelow et al. 1995).

- Section C2.0: References for Appendix C.

\section{C1.0 STATISTICS FOR THE SAFETY SCREENING DATA QUALITY OBJECTIVE}

The safety screening DQO (Dukelow et al. 1995) defines decision limits in terms of one-sided 95 percent confidence intervals. The safety screening DQO limits for total alpha activity are $61.5 \mu \mathrm{Ci} / \mathrm{mL}$ for liquids and $34.4 \mu \mathrm{Ci} / \mathrm{g}$ for solids. The safety screening DQO limit for energetics is $480 \mathrm{~J} / \mathrm{g}$ dry weight by DSC. Confidence intervals on the mean were calculated for each sample using the analytical data from the 1997 core sampling event (Steen 1998).

The upper limit of a one-sided 95 percent confidence interval on the mean is

$$
\hat{\mu}+t_{(\mathrm{df}, 0.05)} \hat{\sigma}_{\hat{\mu}} .
$$

In this equation, $\hat{\mu}$ is the arithmetic mean of the data, $\hat{\sigma}_{\hat{\mu}}$ is the estimate of the standard deviation of the mean, and $\mathrm{t}_{(\mathrm{df}, 0.05)}$ is the quantile from Student's $\mathrm{t}$ distribution with $d f$ degrees of freedom. The degrees of freedom equals the number of samples minus one.

\section{C1.1 TOTAL ALPHA ACTIVITY STATISTICAL ANALYSIS}

For the samples with at least one total alpha activity value above the detection limit, the upper limit of a 95 percent confidence interval is given in Table C1-1. Each confidence interval can be used to make the following statement: If the upper limit is less than $34.4 \mu \mathrm{Ci} / \mathrm{g}$ $(61.5 \mu \mathrm{Ci} / \mathrm{mL}$ for drainable liquid), then reject the null hypothesis that the alpha activity is greater than or equal to $34.4 \mu \mathrm{Ci} / \mathrm{g}(61.5 \mu \mathrm{Ci} / \mathrm{mL}$ for drainable liquid) at the 0.05 level of significance. 
Table C1-1. 95 Percent Upper Confidence Limits for Total Alpha Activity.

\begin{tabular}{|c|c|c|c|c|c|}
\hline 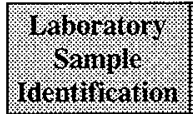 & : Descriprion & (3.:- & ffil & Ulint & Units \\
\hline S97T002179 & $\begin{array}{l}\text { Core 223, segment } 1 \text {, drainable } \\
\text { liquid }\end{array}$ & $3.95 \mathrm{E}-03$ & 1. & $8.87 \mathrm{E}-03$ & $\mu \mathrm{Ci} / \mathrm{mL}$ \\
\hline S97T002199 & $\begin{array}{l}\text { Core 223, segment } 3 \text {, drainable } \\
\text { liquid }\end{array}$ & $3.80 \mathrm{E}-03$ & 1 & $9.70 \mathrm{E}-03$ & $\mu \mathrm{Ci} / \mathrm{mL}$ \\
\hline S97T002204F & Core 223 , segment 4 , lower half & $2.41 \mathrm{E}-02$ & 1 & $2.56 \mathrm{E}-02$ & $\mu \mathrm{Ci} / \mathrm{g}$ \\
\hline S97T002231F & Core 223 , segment 5 , lower half & $4.70 \mathrm{E}-02$ & 1 & $5.55 \mathrm{E}-02$ & $\mu \mathrm{Ci} / \mathrm{g}$ \\
\hline S97T002232F & Core 223 , segment 7 , lower half & $4.25 \mathrm{E}-01$ & 1 & $5.26 \mathrm{E}-01$ & $\mu \mathrm{Ci} / \mathrm{g}$ \\
\hline S97T002234F & Core 223 , segment 8 , lower half & $8.49 \mathrm{E}-02$ & 1 & $1.52 \mathrm{E}-01$ & $\mu \mathrm{Ci} / \mathrm{g}$ \\
\hline S97T002263F & Core 223 , segment 10 lower half & $4.84 \mathrm{E}-01$ & 1 & $5.75 \mathrm{E}-01$ & $\mu \mathrm{Ci} / \mathrm{g}$ \\
\hline S97T002359F & Core 224 , segment 5 , lower half & 3.32E-01 & 1 & 4.61E-01 & $\mu \mathrm{Ci} / \mathrm{g}$ \\
\hline S97T002361F & Core 224 , segment 6 , lower half & $3.98 \mathrm{E}-01$ & 1 & 5.94E-01 & $\mu \mathrm{Ci} / \mathrm{g}$ \\
\hline S97T002363F & Core 224 , segment 8 , lower half & $4.91 \mathrm{E}-01$ & 1 & $6.11 \mathrm{E}-01$ & $\mu \mathrm{Ci} / \mathrm{g}$ \\
\hline S97T002387F & Core 224 , segment 9 , lower half & $1.26 \mathrm{E}+00$ & 1 & $1.32 \mathrm{E}+00$ & $\mu \mathrm{Ci} / \mathrm{g}$ \\
\hline S97T002397F & Core 224 , segment 11 , lower half & $5.98 \mathrm{E}-01$ & 1 & 7.24E-01 & $\mu \mathrm{Ci} / \mathrm{g}$ \\
\hline S98T000694F & Core 223 , segment 6 & $1.26 \mathrm{E}-01$ & 1 & $1.64 \mathrm{E}-01$ & $\mu \mathrm{Ci} / \mathrm{g}$ \\
\hline S98T000703F & Core 223 , segment $6 \mathrm{~A}$ & $1.88 \mathrm{E}-01$ & 1 & $2.29 \mathrm{E}-01$ & $\mu \mathrm{Ci} / \mathrm{g}$ \\
\hline S98T000704F & Core 223 , segment 9 & 1.61E-01 & 1 & 1.99E-01 & $\mu \mathrm{Ci} / \mathrm{g}$ \\
\hline S98T000717F & Core 224 , segment 2 & $9.60 \mathrm{E}-03$ & 1 & $1.34 \mathrm{E}-02$ & $\mu \mathrm{Ci} / \mathrm{g}$ \\
\hline S98T000719F & Core 224 , segment 7 & $1.25 \mathrm{E}-01$ & 1 & $1.48 \mathrm{E}-01$ & $\mu \mathrm{Ci} / \mathrm{g}$ \\
\hline S98T000720F & Core 224 , segment 10 & $4.00 \mathrm{E}-01$ & 1 & $5.96 \mathrm{E}-01$ & $\mu \mathrm{Ci} / \mathrm{g}$ \\
\hline
\end{tabular}

Note:

${ }^{1} \mathrm{~A}$ "less than" value was used in the calculations

Sixteen of the 22 total alpha activity solids mean results from the 1997 core samples were above the detection limit but well below the limit of $34.4 \mu \mathrm{Ci} / \mathrm{g}$. The solids upper limit closest to the threshold was $1.32 \mu \mathrm{Ci} / \mathrm{g}$ for core 224 , segment 9 , lower half. Two of the five total alpha activity liquid mean results from the 1997 core samples were above the detection limit but well below the limit of $61.5 \mu \mathrm{Ci} / \mathrm{mL}$. The liquid upper limit closest to the threshold was $0.0097 \mu \mathrm{Ci} / \mathrm{mL}$ for core 223 , segment 3 . Based on the results from the 1997 core sample, criticality is not an issue for this tank. 


\section{C1.2 DIFFERENTIAL SCANNING CALORIMETRY STATISTICAL ANALYSIS}

For the samples with at least one DSC value above the detection limit, the upper limit of a 95 percent confidence interval is given in Table $\mathrm{C} 1-2$. Each confidence interval can be used to make the following statement: If the upper limit is less than $480 \mathrm{~J} / \mathrm{g}$ dry weight, then reject the null hypothesis that DSC is greater than or equal to $480 \mathrm{~J} / \mathrm{g}$ dry weight at the 0.05 level of significance.

Table C1-2. 95 Percent Upper Confidence Limits for Differential Scanning Calorimetry.

\begin{tabular}{|c|c|c|c|c|c|}
\hline $\begin{array}{l}\text { Laborators } \\
\text { Sannple } \\
\text { Gonitication }\end{array}$ & Jescription & $\lambda$ & . & Wrinet: & Uniss \\
\hline S97T002199 & $\begin{array}{l}\text { Core } 223 \text {, segment } 3 \text {, drainable } \\
\text { liquid }\end{array}$ & $1.53 \mathrm{E}+01$ & 1 & $1.63 \mathrm{E}+01$ & $\begin{array}{l}\mathrm{J} / \mathrm{g} \text { dry } \\
\text { weight }\end{array}$ \\
\hline S97T002347 & Core 224 , segment 5 , lower half & $3.93 \mathrm{E}+01$ & 1 & $1.03 \mathrm{E}+02$ & $\begin{array}{l}\mathrm{J} / \mathrm{g} \text { dry } \\
\text { weight }\end{array}$ \\
\hline S97T002349 & Core 224 , segment 6 , lower half & $1.40 \mathrm{E}+02$ & 1 & $1.57 \mathrm{E}+02$ & $\begin{array}{l}\mathrm{J} / \mathrm{g} \text { dry } \\
\text { weight }\end{array}$ \\
\hline S97T002350 & Core 224 , segment 6 , upper half & $1.25 \mathrm{E}+02$ & 1 & $1.36 \mathrm{E}+02$ & $\begin{array}{l}\mathrm{J} / \mathrm{g} \text { dry } \\
\text { weight }\end{array}$ \\
\hline S97T002400 & Core 224 , segment 11 , upper half & $2.69 \mathrm{E}+02$ & 1 & $3.38 \mathrm{E}+02$ & $\begin{array}{l}\mathrm{J} / \mathrm{g} \text { dry } \\
\text { weight }\end{array}$ \\
\hline
\end{tabular}

Four DSC solids mean results from the 1997 core samples were above the detection limit but below the limit of $480 \mathrm{~J} / \mathrm{g}$ dry weight. The maximum solids upper limit to a 95 percent confidence interval on the mean for DSC was $338 \mathrm{~J} / \mathrm{g}$ dry weight for core 224 , segment 11 , upper half. This is below the threshold limit of $480 \mathrm{~J} / \mathrm{g}$. One DSC liquid mean result from the 1997 core samples was above the detection limit but below the limit of $480 \mathrm{~J} / \mathrm{g}$ dry weight. For this sample, core 223, segment 3 , drainable liquid, the maximum upper limit to a 95 percent confidence interval on the mean was $16.3 \mathrm{~J} / \mathrm{g}$ dry weight. Based on the results from the 1997 core sample, energetic reactions are not an issue for this tank. 


\section{C2.0 APPENDIX C REFERENCES}

Dukelow, G. T., J. W. Hunt, H. Babad, and J. E Meacham, 1995, Tank Safety Screening Data Quality Objective, WHC-SD-WM-SP-004, Rev. 2, Westinghouse Hanford Company, Richland, Washington.

Steen. F. H., 1998, Tank 241-SX-106, Cores 223 and 224, Analytical Results for the Final Report, HNF-SD-WM-DP-288, Rev. 0, Waste Management Federal Services of Hanford, Inc., for Fluor Daniel Hanford, Inc., Richland, Washington. 
HNF-SD-WM-ER-645 Rev. 1

\author{
APPENDIX D \\ EVALUATION TO ESTABLISH THE BEST-BASIS \\ INVENTORY FOR SINGLE-SHELL TANK 241-SX-106
}


HNF-SD-WM-ER-645 Rev. 1

This page intentionally left blank. 


\section{APPENDIX D \\ EVALUATION TO ESTABLISH THE BEST-BASIS INVENTORY FOR SINGLE-SHELL TANK 241-SX-106}

An effort is underway to provide waste inventory estimates that will serve as standard characterization source terms for the various waste management activities (Hodgson and LeClair 1996). As part of this effort, an evaluation of available information for single-shell tank 24.1-SX-106 was performed, and a best-basis inventory was established. This work, detailed in the following sections, follows the methodology that was established by the standard inventory task.

\section{D1.0 CHEMICAL INFORMATION SOURCES}

Available waste information for tank 241-SX-106 includes the following:

- Analytical data from October through December 1997 push core samples (Steen 1998)

- The HDW model document (Agnew et al. 1997) provides tank content estimates in terms of component concentrations and inventories.

\section{D2.0 COMPARISON OF COMPONENT INVENTORY VALUES}

The tank 241-SX-106 chemical and radionuclide inventories predicted from the HDW model estimates (Agnew et al. 1997) and previous best-basis estimates are shown in Tables D2-1 and D2-2. The chemical species are reported without charge designation according to the best-basis inventory convention. 
Table D2-1. Comparison of Inventory Estimates for Nonradioactive Components in Tank 241-SX-106. (2 sheets)

\begin{tabular}{|c|c|c|}
\hline 1: & 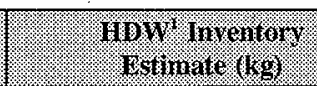 & 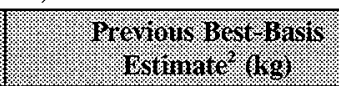 \\
\hline $\mathrm{Al}$ & 91,900 & 44,500 \\
\hline $\mathrm{Bi}$ & 586 & 462 \\
\hline $\mathrm{Ca}$ & 2,790 & 896 \\
\hline $\mathrm{Cl}$ & 17,700 & 11,700 \\
\hline $\mathrm{Cr}$ & 15,800 & 12,000 \\
\hline$F$ & 2,620 & 4,610 \\
\hline $\mathrm{Fe}$ & 1,240 & 2,790 \\
\hline $\mathrm{Hg}$ & 3.78 & 0 \\
\hline $\mathrm{K}$ & 5,250 & 3,370 \\
\hline $\mathrm{La}$ & 11.7 & 21.6 \\
\hline $\mathrm{Mn}$ & 435 & 1,140 \\
\hline $\mathrm{Na}$ & $6.66 \mathrm{E}+05$ & $6.13 \mathrm{E}+05$ \\
\hline $\mathrm{Ni}$ & 779 & 263 \\
\hline $\mathrm{NO}_{2}$ & $2.29 \mathrm{E}+05$ & $1.33 \mathrm{E}+05$ \\
\hline $\mathrm{NO}_{3}$ & $6.42 \mathrm{E}+05$ & $1.08 \mathrm{E}+06$ \\
\hline $\mathrm{OH}$ & $3.46 \mathrm{E}+05$ & $1.23 \mathrm{E}+05$ \\
\hline $\mathrm{Pb}$ & 425 & 330 \\
\hline $\mathrm{PO}_{4}$ & 17,700 & 51,300 \\
\hline $\mathrm{Si}$ & 4,470 & 2,290 \\
\hline $\mathrm{SO}_{4}$ & 47,900 & 37,300 \\
\hline $\mathrm{Sr}$ & 0 & 111 \\
\hline TIC as $\mathrm{CO}_{3}$ & 53,100 & 53,100 \\
\hline TOC & 24,500 & $13,300^{\circ}$ \\
\hline $\mathrm{U}_{\text {TOTAL }}$ & 4,830 & 3,600 \\
\hline
\end{tabular}


Table D2-1. Comparison of Inventory Estimates for Nonradioactive Components in Tank 241-SX-106. (2 sheets)

\begin{tabular}{|c|c|c|}
\hline 1 allye & 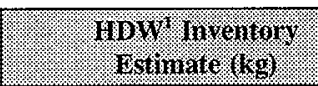 & 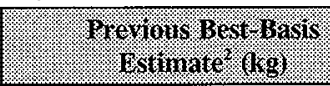 \\
\hline $\mathrm{Zr}$ & 48.2 & 63.2 \\
\hline$\% \mathrm{H}_{2} \mathrm{O}$ & 32.7 & 31.2 \\
\hline Density & 1.61 & NR \\
\hline
\end{tabular}

Notes:

${ }^{1}$ Agnew et al. (1997).

${ }^{2} \mathrm{LMHC}$ (1998).

Table D2-2. Comparison of Inventory Estimates for Selected Radioactive Components in Tank 241-SX-106.

\begin{tabular}{|c|c|c|}
\hline (1) Analgte & 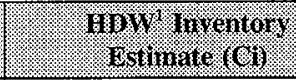 & 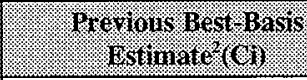 \\
\hline${ }^{14} \mathrm{C}$ & 73.7 & 73.7 \\
\hline${ }^{90} \mathrm{Sr}$ & $2.45 \mathrm{E}+05$ & $3.09 \mathrm{E}+05$ \\
\hline${ }^{99} \mathrm{Tc}$ & 525 & 525 \\
\hline${ }^{129} \mathrm{I}$ & 1.01 & 1.01 \\
\hline${ }^{137} \mathrm{Cs}$ & $5.68 \mathrm{E}+05$ & $3.98 \mathrm{E}+05$ \\
\hline${ }^{154} \mathrm{Eu}$ & 1,330 & 1,330 \\
\hline${ }^{155} \mathrm{Eu}$ & 501 & 501 \\
\hline${ }^{237} \mathrm{~Np}$ & 1.92 & 1.92 \\
\hline${ }^{239} \mathrm{Pu}$ & 103 & 103 \\
\hline${ }^{240} \mathrm{Pu}$ & 17.5 & 17.5 \\
\hline${ }^{241} \mathrm{Pu}$ & 203 & 203 \\
\hline${ }^{241} \mathrm{Am}$ & 125 & 125 \\
\hline${ }^{60} \mathrm{Co}$ & 81.6 & 81.6 \\
\hline
\end{tabular}

Notes:

'Agnew et al. (1997), decayed to January 1, 1994.

${ }^{2}$ LMHC (1998). Most values are based on the HDW model, decayed to January 1, 1994. 


\section{D3.0 COMPONENT INVENTORY EVALUATION}

\section{D3.1 WASTE HISTORY}

Appendix A3.1 gives a full account of the waste history. Waste initially added to tank 241-SX-106 in 1954 consisted of flush water from miscellaneous sources. This continued until 1963 with some material being transferred to a crib. From 1956 through 1963 various transfers were made to other SX farm tanks. From 1964 to 1975 , various flush waters from miscellaneous sources were added to the tank including some of Hanford Laboratory Operations and Battelle Northwest Laboratory waste.

In support of the 242-S Evaporator campaign, supernatant was transferred to and from the tank from 1972 to 1976 . From 1978 to 1980 , similar operations were conducted. In 1980 , a neutralized solution of $\mathrm{HNO}_{3} / \mathrm{KMnO}_{4}$ was added to the tank to increase volume reduction. Water from miscellaneous sources, likely intrusions (i.e., rain water), was added to the tank from 1983 to 1993.

\section{D3.2 CONTRIBUTING WASTE TYPES}

The HDW model (Agnew et al. 1997) predicts that the tank contains a total of 2,037 kL (538 kgal) of waste. This waste consists of $3.78 \mathrm{~kL}(1 \mathrm{kgal})$ of REDOX saltcake waste and $2,032 \mathrm{~kL}(537 \mathrm{kgal})$ of saltcake and supernatant predicted from the SMM. Although the total waste volume for SMM saltcake is $2,032 \mathrm{~kL}$ ( $537 \mathrm{kgal}$ ), the TLM only accounts for $1,820 \mathrm{~kL}$ (476 kgal) of solids in the SMM saltcake.

The Sort on Radioactive Waste Type model (Hill et al. 1995) lists high-level REDOX process waste and evaporator bottoms as the primary and secondary waste types, respectively. Evaporator bottoms waste is the generic Sort on Radioactive Waste Type definition for saltcake that is roughly equivalent to the SMM waste types that result from evaporation of REDOX process supernatant in the 242-S Evaporator. Hill et al. also list REDOX process ion exchange as a tertiary waste contributor.

Hanlon (1998) reports $2,037 \mathrm{~kL}$ (538 kgal) of waste that consists of $231 \mathrm{~kL}$ (61 kgal) of supernatant, $45 \mathrm{~kL}(12 \mathrm{kgal})$ of sludge, and $1,760 \mathrm{~kL}(465 \mathrm{kgal})$ of saltcake with $848 \mathrm{~kL}$ (224 kgal) of drainable interstitial liquid.

\section{D3.3 EVALUATION OF TANK WASTE VOLUME}

The total volume in tank $241-\mathrm{SX}-106$ is $2,037 \mathrm{~kL}$ (538 kgal), as specified by Hanlon (1998) and Agnew et al. (1997). 
The volume of liquid and solids in the tank, used to compute the inventories, was derived from the mass of liquid and solids recovered during extrusion of the samples in the laboratory (Steen 1998). For each sample, the mass of liquid and solids was converted to a volumetric basis using the liquid specific gravity of 1.413 and the solid density of $1.517 \mathrm{~g} / \mathrm{mL}$. The average volume percent of liquid in the tank was 40.0 percent. Therefore, 40.0 percent of the tank waste volume is equal to $814 \mathrm{~kL}$ ( $215 \mathrm{kgal})$ of liquid. Taking the difference, the solids volume is $1,223 \mathrm{~kL}$ (323 kgal).

\section{D3.4 ASSUMPTIONS USED}

An engineering evaluation based on tank 241-SX-106 sample results was conducted to predict tank contents and compare results with the previous best-basis and HDW model results. The engineering evaluation assumes the following.

- The total tank volume used is the one listed in both Hanlon (1998) and Agnew et al. (1997) $2,037 \mathrm{~kL}(538 \mathrm{kgal})$.

- The liquid and solids volumes used to calculate analyte inventories are specified in Section D3.3. The solids analytical mean density is $1.517 \mathrm{~g} / \mathrm{mL}$, and specific gravity of the liquids is 1.413 .

- All radionuclide data are corrected to January. 1, 1994.

\section{D3.5 BASIS FOR CALCULATIONS USED IN THIS ENGINEERING EVALUATION}

Table D3-1 summarizes the engineering evaluation approach.

Table D3-1. Engineering Evaluation Approach Used for Tank 241-SX-106.

\begin{tabular}{|c|c|c|}
\hline Mine of Waste & How Calculated & Sheel Mrthod \\
\hline Supernatant & $\begin{array}{l}\text { Multiplied sample-based supernatant } \\
\text { concentrations (see Table B3-8) by } \\
814 \mathrm{~kL} \text { (215 kgal) }\end{array}$ & $\begin{array}{l}\text { Compare with predicted } \\
\text { SMMS liquid waste types } \\
\text { (Agnew et al.1997). }\end{array}$ \\
\hline Saltcake & $\begin{array}{l}\text { Multiplied sample-based solids } \\
\text { concentrations (see Table B3-7) by the } \\
\text { mean density of } 1.517 \mathrm{~g} / \mathrm{mL} \text { and solids } \\
\text { volume of } 1,223 \mathrm{~kL} \text { ( } 323 \mathrm{kgal} \text { ). }\end{array}$ & $\begin{array}{l}\text { Compared sample-based } \\
\text { concentrations for other } \\
\text { tanks containing SMMS1 } \\
\text { and SMMS2 solid waste } \\
\text { (see Tables D3-2 and } \\
\text { D3-3). }\end{array}$ \\
\hline
\end{tabular}




\section{D3.5.1 Supernatant Mixing Model S1 Saltcake}

The SMMS1 component concentrations for four tanks (241-S-101, 241-S-102, 241-U-106, and 241-U-109) known to contain the same saltcake waste type were averaged to provide a generalized composition template for SMMS1 saltcake (Sasaki et al. 1998). This composition for SMMS1 saltcake is compared with tank 241-SX-106 solid sample concentrations in Table D3-2. In addition, the saltcake composition predicted by Agnew et al. (1997) for the 242-S Evaporator saltcake generated from 1973 to 1976 (S1-SltCk) is shown in Table D3-2.

While the template and the HDW model values are reasonably comparable, some of the major analytes are noticeably different. In general, neither the template nor the model are very good predictors for the solid analyte concentrations in this tank. This may be attributed to the simplifying assumptions made in the model, the complicated and unique history associated with evaporation concentrates, and potentially biased sample data.

Table D3-2. Tank 241-SX-106 Waste Type Supernatant Mixing Model S1 Saltcake Concentrations. (2 sheets)

\begin{tabular}{|c|c|c|c|}
\hline : Amile: & 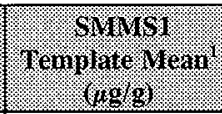 & 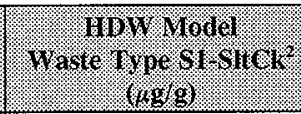 & 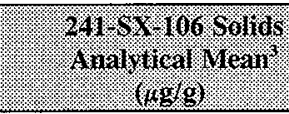 \\
\hline $\mathrm{Al}$ & 15,100 & 33,400 & 19,600 \\
\hline $\mathrm{Bi}$ & 73.5 & 144 & $<32.8^{4}$ \\
\hline $\mathrm{Ca}$ & 282 & 1,210 & $150^{4}$ \\
\hline $\mathrm{Cl}$ & 3,840 & 2,910 & 6,550 \\
\hline $\mathrm{CO}_{3}$ & NR & 16,600 & 22,200 \\
\hline $\mathrm{Cr}$ & 5,440 & 7,870 & 3,790 \\
\hline$F$ & 6,260 & 611 & 530 \\
\hline $\mathrm{Fe}$ & 1,630 & 539 & $340^{4}$ \\
\hline $\mathrm{Hg}$ & NR & 1.03 & $\mathrm{NR}$ \\
\hline $\mathrm{K}$ & 1,110 & 1,260 & $1,120^{4}$ \\
\hline $\mathrm{La}$ & 40.0 & 0.75 & $<16.4^{4}$ \\
\hline $\mathrm{Mn}$ & 684 & 175 & 356 \\
\hline $\mathrm{Na}$ & $1.82 \mathrm{E}+05$ & $2.31 \mathrm{E}+05$ & $1.87 \mathrm{E}+05$ \\
\hline $\mathrm{Ni}$ & 155 & 340 & $20.0^{4}$ \\
\hline $\mathrm{NO}_{2}$ & 57,500 & 82,400 & 71,700 \\
\hline $\mathrm{NO}_{3}$ & $1.63 \mathrm{E}+05$ & $2.57 \mathrm{E}+05$ & $2.86 \mathrm{E}+05$ \\
\hline $\mathrm{Pb}$ & 192 & 109 & $<38.2^{4}$ \\
\hline
\end{tabular}


Table D3-2. Tank 241-SX-106 Waste Type Supernatant Mixing Model S1 Saltcake Concentrations. (2 sheets)

\begin{tabular}{|c|c|c|c|}
\hline 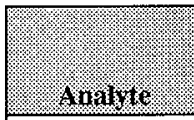 & 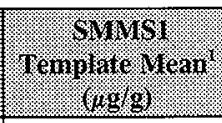 & 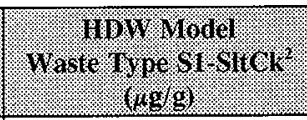 & Inulutical mean \\
\hline $\mathrm{PO}_{4}$ & 34,000 & 5,310 & 13,900 \\
\hline $\mathrm{Si}$ & 1,990 & 1,870 & $200^{4}$ \\
\hline $\mathrm{SO}_{4}$ & 13,800 & 12,700 & 5,390 \\
\hline $\mathrm{Sr}$ & 7.00 & 0 & $<3.28^{4}$ \\
\hline TOC & 8,950 & 6,130 & 3,570 \\
\hline $\mathrm{U}$ & 914 & 2,060 & $<167^{4}$ \\
\hline $\mathrm{Zr}$ & 47.0 & 8.71 & $9.68^{4}$ \\
\hline Density $(\mathrm{g} / \mathrm{mL})$ & 1.63 & 1.86 & 1.517 \\
\hline \multicolumn{4}{|c|}{ Radionucintes (fortg) } \\
\hline Total alpha & N/A & N/A & 0.288 \\
\hline${ }^{90} \mathrm{Sr}$ & 90.3 & 110 & NR \\
\hline${ }^{137} \mathrm{Cs}$ & 153 & 175 & $\mathrm{NR}$ \\
\hline
\end{tabular}

Notes:

$\begin{array}{lll}\mathrm{N} / \mathrm{A} & = & \text { not available } \\ \mathrm{NR} & = & \text { not requested }\end{array}$

'Sasaki et al. (1998)

${ }^{2}$ Agnew et al. (1997)

${ }^{3}$ Table B3-7

${ }^{4}$ Acid digestion results from RGS samples (LMHC 1998)

\section{D3.5.2 Supernatant Mixing Model S2 Saltcake}

The SMMS2 component concentrations for five tanks (241-S-101, 241-S-102, 241-U-102, 241-U-107, and 241-U-109) known to contain the same saltcake waste type were averaged to provide a generalized composition template for SMMS2 saltcake (Sasaki et al. 1998). This composition for SMMS2 saltcake is compared with tank 241-SX-106 solid sample concentrations in Table D3-3. In addition, the saltcake composition predicted by Agnew et al. (1997) for 242-S Evaporator saltcake generated from 1977 to 1980 (S2-SItSlr) is shown in Table D3-3.

While the template and the HDW model values are reasonably comparable, some of the major analytes are noticeably different. In general, neither the template nor the model are very good 
predictors for the solid analyte concentrations in this tank. This may be attributed to the simplifying assumptions made in the model, the complicated and unique history associated with evaporation concentrates, and potentially biased sample data.

Table D3-3. Tank 241-SX-106 Waste Type Supernatant Mixing Model S2 Saltcake Concentrations. (2 sheets)

\begin{tabular}{|c|c|c|c|}
\hline Aritye: & 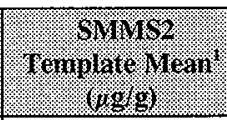 & 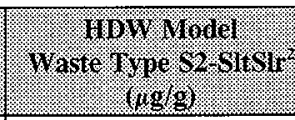 & 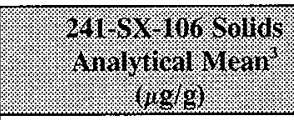 \\
\hline $\mathrm{Al}$ & 11,000 & 39,500 & 19,600 \\
\hline $\mathrm{Bi}$ & 161 & 622 & $<32.8^{4}$ \\
\hline $\mathrm{Ca}$ & 279 & 400 & $150^{4}$ \\
\hline $\mathrm{Cl}$ & 3,640 & 2,450 & 6,550 \\
\hline $\mathrm{CO}_{3}$ & NR & 21,900 & 22,200 \\
\hline $\mathrm{Cr}$ & 3,460 & 3,620 & 3,790 \\
\hline$F$ & 520 & 1,190 & 530 \\
\hline $\mathrm{Fe}$ & 696 & 105 & $340^{4}$ \\
\hline $\mathrm{Hg}$ & NR & 2.52 & NR \\
\hline $\mathrm{K}$ & 1,060 & 2,630 & $1,120^{4}$ \\
\hline $\mathrm{La}$ & NR & 1.21 & $<16.4^{4}$ \\
\hline $\mathrm{Mn}$ & 258 & 67.5 & 356 \\
\hline $\mathrm{Na}$ & $1.96 \mathrm{E}+05$ & $2.65 \mathrm{E}+05$ & $1.87 \mathrm{E}+05$ \\
\hline $\mathrm{Ni}$ & 67.0 & 109 & $20.0^{4}$ \\
\hline $\mathrm{NO}_{2}$ & 38,800 & 98,800 & 71,700 \\
\hline $\mathrm{NO}_{3}$ & $3.78 \mathrm{E}+05$ & $1.69 \mathrm{E}+05$ & $2.86 \mathrm{E}+05$ \\
\hline $\mathrm{Pb}$ & 87.0 & 237 & $<38.2^{4}$ \\
\hline $\mathrm{PO}_{4}$ & 12,900 & 16,700 & 13,900 \\
\hline $\mathrm{Si}$ & 445 & 1,080 & $200^{4}$ \\
\hline $\mathrm{SO}_{4}$ & 11,500 & 29,700 & 5,390 \\
\hline $\mathrm{Sr}$ & 28.0 & 0 & $<3.28^{4}$ \\
\hline TOC & 3,270 & 13,300 & 3,570 \\
\hline $\mathrm{U}$ & 964 & 940 & $<167^{4}$ \\
\hline $\mathrm{Zr}$ & 13.0 & 30.3 & $9.68^{4}$ \\
\hline Density $(\mathrm{g} / \mathrm{mL})$ & 1.56 & 1.95 & 1.517 \\
\hline
\end{tabular}


Table D3-3. Tank 241-SX-106 Waste Type Supernatant Mixing Model S2 Saltcake Concentrations. (2 sheets)

\begin{tabular}{|c|c|c|c|}
\hline : & $\begin{array}{l}\text { SMML2 } \\
\text { renpinte Mran } \\
(0 \mathrm{~g} / \mathrm{g}\end{array}$ & 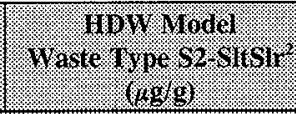 & 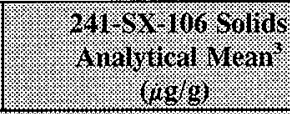 \\
\hline \multicolumn{4}{|c|}{ Radionuchides $(2 \mathrm{c} / \mathrm{g})$. } \\
\hline Total alpha & N/A & $\mathrm{N} / \mathrm{A}$ & 0.288 \\
\hline${ }^{90} \mathrm{Sr}$ & 85.7 & 39.6 & NR \\
\hline${ }^{137} \mathrm{Cs}$ & 112 & 305 & NR \\
\hline
\end{tabular}

Notes:

'Sasaki et al. (1998)

${ }^{2}$ Agnew et al. (1997)

${ }^{3}$ Table B3-7

${ }^{4}$ Acid digestion results from RGS samples (LMHC 1998)

\section{D3.5.3 Supernatant Mixing Model}

The tank 241-SX-106 supernatant concentrations from the analytical liquid means are provided in Table D3-4. In addition, the supernatant compositions predicted by Agnew et al. (1997) for S1-SltCk and S2-SItSIr are shown in Table D3-4. The HDW model concentrations compare reasonably well for some of the major analytes; however, many are noticeably different. Further, the model is not consistent in estimating concentrations.

Table D3-4. Tank 241-SX-106 Waste Type Supernatant Mixing Model Supernatant Concentrations. (2 sheets)

\begin{tabular}{|c|c|c|c|}
\hline Analyte & 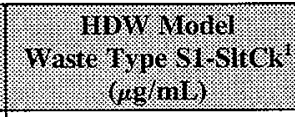 & 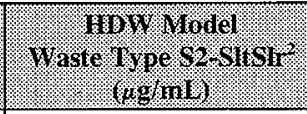 & 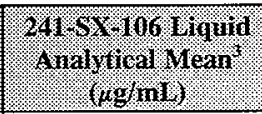 \\
\hline $\mathrm{Al}$ & 54,200 & 57,900 & 25,900 \\
\hline $\mathrm{Bi}$ & 410 & 1,020 & $<60.1$ \\
\hline $\mathrm{Ca}$ & 256 & 331 & $<60.1$ \\
\hline $\mathrm{Cl}$ & 8,280 & 9,180 & 11,700 \\
\hline $\mathrm{CO}_{3}$ & 26,700 & 31,600 & 25,600 \\
\hline $\mathrm{Cr}$ & 4,620 & 4,630 & 129 \\
\hline $\mathrm{F}$ & 1,740 & 4,460 & 311 \\
\hline
\end{tabular}


Table D3-4. Tank 241-SX-106 Waste Type Supernatant Mixing Model Supernatant Concentrations. (2 sheets)

\begin{tabular}{|c|c|c|c|}
\hline Inalyt: & 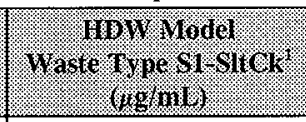 & 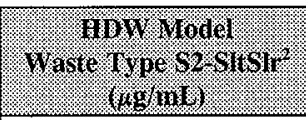 & 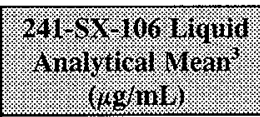 \\
\hline $\mathrm{Fe}$ & 39.0 & 67.0 & $<30.1$ \\
\hline $\mathrm{Hg}$ & 2.25 & 2.45 & NR \\
\hline $\mathrm{K}$ & 3,590 & 9,860 & 3,890 \\
\hline $\mathrm{La}$ & 2.14 & 4.56 & $<30.1$ \\
\hline $\mathrm{Mn}$ & 61.7 & 83.5 & $<6.01$ \\
\hline $\mathrm{Na}$ & $3.37 \mathrm{E}+05$ & $5.10 \mathrm{E}+05$ & $2.45 \mathrm{E}+05$ \\
\hline $\mathrm{Ni}$ & 71.0 & 92.8 & $<12.0$ \\
\hline $\mathrm{NO}_{2}$ & $1.26 \mathrm{E}+05$ & $1.24 \mathrm{E}+05$ & $1.31 \mathrm{E}+05$ \\
\hline $\mathrm{NO}_{3}$ & $1.62 \mathrm{E}+05$ & $1.63 \mathrm{E}+05$ & $2.07 \mathrm{E}+05$ \\
\hline $\mathrm{Pb}$ & 311 & 888 & $<60.1$ \\
\hline $\mathrm{PO}_{4}$ & 15,100 & 16,700 & 3,220 \\
\hline $\mathrm{Si}$ & 769 & 951 & 85.7 \\
\hline $\mathrm{SO}_{4}$ & 36,300 & 43,600 & 5,410 \\
\hline $\mathrm{Sr}$ & 0.00 & 0.00 & $<6.01$ \\
\hline TOC & 17,500 & 50,100 & 4,050 \\
\hline $\mathrm{U}$ & 639 & 953 & $<300$ \\
\hline $\mathrm{Zr}$ & 24.8 & 55.7 & $<6.01$ \\
\hline Density $(\mathrm{g} / \mathrm{mL})$ & 1.63 & 1.83 & 1.413 \\
\hline \multicolumn{4}{|c|}{ Radionuchades (o Cliny) } \\
\hline Total alpha & N/A & N/A & $<3.64 \mathrm{E}-03$ \\
\hline${ }^{90} \mathrm{Sr}$ & 33.5 & 44.4 & NR \\
\hline${ }^{137} \mathrm{Cs}$ & 400 & 1,090 & $\mathrm{NR}$ \\
\hline
\end{tabular}

Notes:

${ }^{1}$ Agnew et al. (1997) after applying a density of $1.63 \mathrm{~g} / \mathrm{mL}$

${ }^{2}$ Agnew et al. (1997) after applying a density of $1.83 \mathrm{~g} / \mathrm{mL}$

${ }^{2}$ See Table B3-8 


\section{D3.6 ESTIMATED COMPONENT INVENTORIES}

The chemical inventory of tank 241-SX-106 is based on the estimated saltcake and supernatant volumes (see Table D3-1). The resulting inventories are provided in Table D3-5. The inventories estimated by the HDW model are included for comparison.

Total Hydroxide. Once the best-basis inventories were determined, the hydroxide inventory was calculated by performing a charge balance with the valence of other analytes. This charge balance approach is consistent with that used by Agnew et al. (1997).

Table D3-5. Comparison of Inventory Estimates for Tank 241-SX-106. (2 sheets)

\begin{tabular}{|c|c|c|c|c|}
\hline (2): & 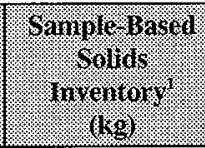 & 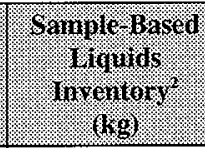 & 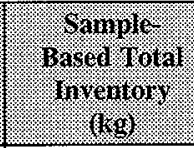 & 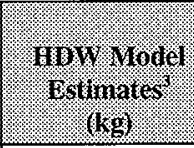 \\
\hline $\mathrm{Al}$ & 36,400 & 21,100 & 57,500 & 91,900 \\
\hline $\mathrm{Bi}$ & $<60.9$ & $<48.9$ & $<110$ & 586 \\
\hline $\mathrm{Ca}$ & 278 & $<48.9$ & $<327$ & 2,790 \\
\hline $\mathrm{Cl}$ & 12,200 & 9,520 & 21,700 & 17,700 \\
\hline $\mathrm{TIC}$ as $\mathrm{CO}_{3}$ & 41,200 & 20,800 & 62,000 & 53,100 \\
\hline $\mathrm{Cr}$ & 7,030 & 105 & 7,140 & 15,800 \\
\hline$F$ & 983 & 253 & 1,240 & 2,620 \\
\hline $\mathrm{Fe}$ & 631 & $<24.5$ & $<656$ & 1,240 \\
\hline$K$ & 2,070 & 3,170 & 5,240 & 5,250 \\
\hline $\mathrm{La}$ & $<30.5$ & $<24.5$ & $<55.0$ & 11.7 \\
\hline $\mathrm{Mn}$ & 660 & $<4.89$ & $<665$ & 435 \\
\hline $\mathrm{Na}$ & $3.47 \mathrm{E}+05$ & $1.99 \mathrm{E}+05$ & $5.46 \mathrm{E}+05$ & $6.66 \mathrm{E}+05$ \\
\hline $\mathrm{Ni}$ & $<37.1$ & $\begin{array}{l}<9.77 \\
\end{array}$ & $<46.9$ & 779 \\
\hline $\mathrm{NO}_{2}$ & $1.33 \mathrm{E}+05$ & $1.07 \mathrm{E}+05$ & $2.40 \mathrm{E}+05$ & $2.29 \mathrm{E}+05$ \\
\hline $\mathrm{NO}_{3}$ & $5.31 \mathrm{E}+05$ & $1.68 \mathrm{E}+05$ & $6.99 \mathrm{E}+05$ & $6.42 \mathrm{E}+05$ \\
\hline $\mathrm{Pb}$ & $<70.9$ & $<48.9$ & $<120$ & 425 \\
\hline $\mathrm{PO}_{4}$ & 25,800 & 2,620 & 28,400 & 17,700 \\
\hline $\mathrm{Si}$ & 372 & 69.8 & 442 & 4,470 \\
\hline $\mathrm{SO}_{4}$ & 10,000 & 4,400 & 14,400 & 47,900 \\
\hline $\mathrm{Sr}$ & $<6.09$ & $<4.89$ & $<11.0$ & 0.00 \\
\hline TOC & 6,620 & 3,300 & 9,920 & 24,500 \\
\hline
\end{tabular}


Table D3-5. Comparison of Inventory Estimates for Tank 241-SX-106. (2 sheets)

\begin{tabular}{|c|c|c|c|c|}
\hline Component & 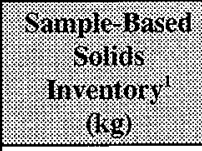 & 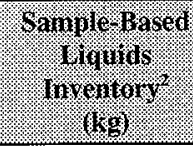 & 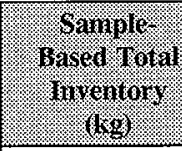 & 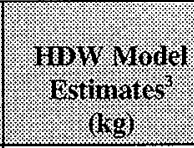 \\
\hline$U_{\text {TOTAL }}$ & $<309$ & $<244$ & $<553$ & 4,830 \\
\hline $\mathrm{Zr}$ & 18.0 & $<4.89$ & $<22.8$ & 48.2 \\
\hline Total alpha (Ci) & 534 & $<2.96$ & $<537$ & NR \\
\hline${ }^{137} \mathrm{Cs}(\mathrm{Ci})^{4}$ & NR & NR & NR & $5.68 \mathrm{E}+05$ \\
\hline${ }^{90} \mathrm{Sr}(\mathrm{Ci})^{4}$ & NR & NR & NR & $2.45 \mathrm{E}+05$ \\
\hline
\end{tabular}

Notes:

'Based on the mean solids concentrations from Tables D3-2 with a volume of $1,223 \mathrm{~kL}$ (323 kgal) and a density of $1.517 \mathrm{~g} / \mathrm{mL}$.

${ }^{2}$ Based on the mean liquid concentrations from Tables D3-4 with a volume of $814 \mathrm{~kL}$ (215 kgal).

${ }^{3}$ Agnew et al. (1997)

${ }^{4}$ Radionuclides decayed to January 1, 1994.

\section{D4.0 DEFINE THE BEST-BASIS AND ESTABLISH COMPONENT INVENTORIES}

An effort is underway to provide waste inventory estimates that will serve as standard characterization source terms for the various waste management activities (Hodgson and LeClair 1996). As part of this effort, an evaluation of chemical information for tank 241-SX-106 was performed, and a best-basis inventory was established. This work, detailed in the following sections, follows the methodology that was established by the standard inventory task. The following information was used in the evaluation:

- Analytical data from the 1997 push-mode core sampling event (Appendix B)

- Inventory estimates generated for this tank from the HDW model (Agnew et al. 1997).

Based on this engineering assessment, a best-basis inventory was developed for tank 241-SX-106 using the 1997-core sampling analytical data. Where analytical data were not available, the HDW model inventory estimates reported by Agnew et al. (1997) were used as the best basis for this tank. 
Best-basis tank inventory values are derived for 46 key radionuclides (as defined in Section 3.1 of Kupfer et al. 1997), all decayed to a common report date of January 1, 1994. Often, waste sample analyses have only reported ${ }^{90} \mathrm{Sr},{ }^{137} \mathrm{Cs},{ }^{239 / 240} \mathrm{Pu}$, and total uranium, or total beta and total alpha, while other key radionuclides such as ${ }^{60} \mathrm{Co},{ }^{99} \mathrm{Tc},{ }^{129} \mathrm{I},{ }^{154} \mathrm{Eu},{ }^{155} \mathrm{Eu}$, and ${ }^{241} \mathrm{Am}$, have been infrequently reported. Therefore, it has been necessary to derive most of the 46 key radionuclides by computer models. These models estimate radionuclide activity in batches of reactor fuel, account for the split of radionuclides to various separations plant waste streams, and track their movement with tank waste transactions. (These computer models are described in Kupfer et al. 1997, Section 6.1, and in Watrous and Wootan 1997.)

Model-generated values for radionuclides in any of 177 tanks are reported in the HDW Revision 4 model results (Agnew et al. 1997). The best-basis value for any one analyte may be either a model result or a sample or engineering assessment-based result, if available.

The best-basis inventory estimate for tank 241-SX-106 is presented in Tables D4-1 and D4-2. The mercury inventory was specified in Simpson (1998). The inventory of strontium was calculated from the ${ }^{90} \mathrm{Sr}$ activity. The inventory of ${ }^{90} \mathrm{Sr}$ was based on a weighted average of the template estimates for waste types SMMS1 and SMMS2 from Sasaki et al. (1998). The inventory of ${ }^{137} \mathrm{Cs}$ was based on the heat load calculated from the difference between the total heat load estimate of $3,180 \mathrm{~W}(10,840 \mathrm{Btu} / \mathrm{hr})$ provided by Kummerer (1995) and the heat load attributed to ${ }^{90} \mathrm{Sr}$.

The inventory values reported in Tables D4- 1 and D4-2 are subject to change. Refer to the Tank Characterization Database for the most current inventory values.

Table D4-1. Best-Basis Inventory Estimates for Nonradioactive Components in Tank 241-SX-106 (Effective May 31, 1998). (2 sheets)

\begin{tabular}{|c|c|c|c|}
\hline Analut : & 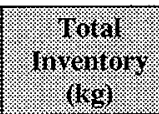 & (5. M. I. L. or. (1) & Cominent: : \\
\hline Al & 57,500 & $S$ & . \\
\hline $\mathrm{Bi}$ & 0 & $\mathrm{E}$ & Not expected based on process history \\
\hline $\mathrm{Ca}$ & 278 & S/E & Solids only \\
\hline $\mathrm{Cl}$ & 21,700 & $S$ & \\
\hline $\mathrm{TIC}$ as $\mathrm{CO}_{3}$ & 62,000 & $S$ & \\
\hline $\mathrm{Cr}$ & 7,140 & $S$ & \\
\hline $\mathrm{F}$ & 1,240 & S & \\
\hline $\mathrm{Fe}$ & 631 & $\mathrm{~S} / \mathrm{E}$ & Solids only \\
\hline $\mathrm{Hg}$ & 0 & $\mathrm{E}$ & Simpson (1998) \\
\hline
\end{tabular}


Table D4-1. Best-Basis Inventory Estimates for Nonradioactive Components in Tank 241-SX-106 (Effective May 31, 1998). (2 sheets)

\begin{tabular}{|c|c|c|c|}
\hline . & 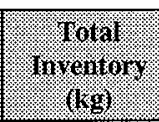 & 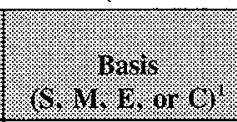 & Cominerit: \\
\hline $\mathrm{K}$ & 5,240 & $S$ & \\
\hline $\mathrm{La}$ & 55 & $\mathrm{~S} / \mathrm{E}$ & Upper bounding limit \\
\hline $\mathrm{Mn}$ & 660 & S/E & Solids only \\
\hline $\mathrm{Na}$ & $5.46 \mathrm{E}+05$ & $\mathrm{~S}$ & \\
\hline $\mathrm{Ni}$ & 0 & $E$ & Not expected based on process history \\
\hline $\mathrm{NO}_{2}$ & $2.40 \mathrm{E}+05$ & $S$ & \\
\hline $\mathrm{NO}_{3}$ & $6.99 E+05$ & $S$ & \\
\hline $\mathrm{OH}_{\text {TOTAL }}$ & $1.71 \mathrm{E}+05$ & $\mathrm{C}$ & \\
\hline $\mathrm{Pb}$ & 120 & $\mathrm{~S} / \mathrm{E}$ & Upper bounding limit \\
\hline $\mathrm{PO}_{4}$ & 28,400 & $S$ & \\
\hline $\mathrm{Si}$ & 442 & $S$ & \\
\hline $\mathrm{SO}_{4}$ & 14,400 & $S$ & \\
\hline $\mathrm{Sr}$ & 4.00 & $\mathrm{E}$ & $\begin{array}{l}\text { Calculated from }{ }^{90} \mathrm{Sr} \text { assuming that }{ }^{90} \mathrm{Sr} \text { is } \\
30 \text { wt \% of total strontium }\end{array}$ \\
\hline TOC & 9,920 & $S$ & \\
\hline $\mathrm{U}_{\text {TOTAL }}$ & 553 & $\mathrm{~S} / \mathrm{E}$ & Upper bounding limit \\
\hline $\mathrm{Zr}$ & 18 & $\mathrm{~S} / \mathrm{E}$ & Solids only \\
\hline
\end{tabular}

Note:

${ }^{1} S=$ sample based (see Appendix B), $M=H D W$ model based (Agnew et al. 1997), $E$ =engineering assessment based, and $\mathrm{C}=$ calculated by charge balance; includes oxides as hydroxides, not including $\mathrm{CO}_{3}$, $\mathrm{NO}_{2}, \mathrm{NO}_{3}, \mathrm{PO}_{4}, \mathrm{SO}_{4}$, and $\mathrm{SiO}_{3}$. 
Table D4-2. Best-Basis Inventory Estimates for Radioactive Components in Tank 241-SX-106 Decayed to January 1, 1994 (Effective May 31, 1998).

(3 sheets)

\begin{tabular}{|c|c|c|c|}
\hline Anallac & 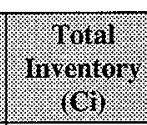 & 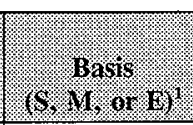 & 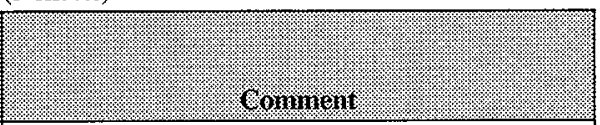 \\
\hline${ }^{3} \mathrm{H}$ & 513 & $\mathrm{M}$ & \\
\hline${ }^{14} \mathrm{C}$ & 73.7 & $\mathrm{M}$ & \\
\hline${ }^{59} \mathrm{Ni}$ & 4.80 & $\mathrm{M}$ & \\
\hline${ }^{60} \mathrm{Co}$ & $81: 6$ & $\mathrm{M}$ & \\
\hline${ }^{63} \mathrm{Ni}$ & 470 & $\mathbf{M}$ & \\
\hline${ }^{79} \mathrm{Se}$ & 7.35 & $\mathrm{M}$ & \\
\hline${ }^{90} \mathrm{Sr}$ & $1.70 \mathrm{E}+05$ & $E$ & $\begin{array}{l}\text { Based on the template estimates for waste types } \\
\text { SMMS1 saltcake and SMMS2 saltcake from Sasaki } \\
\text { et al. (1998) }\end{array}$ \\
\hline${ }^{90} \mathrm{Y}$ & $1.70 \mathrm{E}+05$ & E & Based on the ${ }^{90} \mathrm{Sr}$ activity \\
\hline${ }^{93} \mathrm{Zr}$ & 36.1 & $\mathrm{M}$ & \\
\hline${ }^{93 \mathrm{~m}} \mathrm{Nb}$ & 26.2 & $\mathrm{M}$ & \\
\hline${ }^{99} \mathrm{Tc}$ & 525 & $M$ & \\
\hline${ }^{106} \mathrm{Ru}$ & 0.0145 & $\mathrm{M}$ & \\
\hline${ }^{113 \mathrm{~m}} \mathrm{Cd}$ & 189 & M & \\
\hline${ }^{125} \mathrm{Sb}$ & 351 & M & \\
\hline${ }^{126} \mathrm{Sn}$ & 11.1 & $M$ & \\
\hline${ }^{129} \mathrm{I}$ & 1.01 & $\mathrm{M}$ & \\
\hline${ }^{134} \mathrm{Cs}$ & 5.57 & $\mathrm{M}$ & \\
\hline${ }^{137} \mathrm{Cs}$ & $4.71 \mathrm{E}+05$ & E & $\begin{array}{l}\text { Based on the heat load calculated from the } \\
\text { difference between the total heat load estimate } \\
\text { from Kummerer (1995) and the heat load } \\
\text { attributed to }{ }^{90} \mathrm{Sr}\end{array}$ \\
\hline${ }^{137 \mathrm{~m}} \mathrm{Ba}$ & $4.45 \mathrm{E}+05$ & E & Based on 0.946 of the ${ }^{137} \mathrm{Cs}$ activity \\
\hline${ }^{151} \mathrm{Sm}$ & 25,900 & M & \\
\hline${ }^{152} \mathrm{Eu}$ & 8.49 & $\mathrm{M}$ & \\
\hline${ }^{154} \mathrm{Eu}$ & 1,330 & $M$ & \\
\hline${ }^{155} \mathrm{Eu}$ & 501 & $\mathrm{M}$ & \\
\hline${ }^{226} \mathrm{Ra}$ & $3.15 \mathrm{E}-04$ & $\mathrm{M}$ & \\
\hline${ }^{227} \mathrm{Ac}$ & 0.00199 & $\mathrm{M}$ & : \\
\hline
\end{tabular}


Table D4-2. Best-Basis Inventory Estimates for Radioactive Components in Tank 241-SX-106 Decayed to January 1, 1994 (Effective May 31, 1998).

(3 sheets)

\begin{tabular}{|c|c|c|c|}
\hline onalyte & $\begin{array}{l}\text { Tohat } \\
\text { minentory } \\
\text { (C) }\end{array}$ & S. Masis: & Gominerit. \\
\hline${ }^{228} \mathrm{Ra}$ & 0.307 & M & \\
\hline${ }^{229} \mathrm{Th}$ & 0.00720 & M & \\
\hline${ }^{231} \mathrm{~Pa}$ & 0.00913 & M & \\
\hline${ }^{232} \mathrm{Th}$ & 0.0204 & M & \\
\hline${ }^{232} \mathrm{U}$ & 0.181 & $\mathrm{~S} / \mathrm{E} / \mathrm{M}$ & $\begin{array}{l}\text { Based on ICP uranium sample result ratioed to } \\
\text { HDW estimates for uranium isotopes }\end{array}$ \\
\hline${ }^{233} \mathrm{U}$ & 0.693 & $\mathrm{~S} / \mathrm{E} / \mathrm{M}$ & $\begin{array}{l}\text { Based on ICP uranium sample result ratioed to } \\
\text { HDW estimates for uranium isotopes }\end{array}$ \\
\hline${ }^{234} \mathrm{U}$ & 0.203 & $\mathrm{~S} / \mathrm{E} / \mathrm{M}$ & $\begin{array}{l}\text { Based on ICP uranium sample result ratioed to } \\
\text { HDW estimates for uranium isotopes }\end{array}$ \\
\hline${ }^{235} \mathrm{U}$ & 0.00823 & $\mathrm{~S} / \mathrm{E} / \mathrm{M}$ & $\begin{array}{l}\text { Based on ICP uranium sample result ratioed to } \\
\text { HDW estimates for uranium isotopes }\end{array}$ \\
\hline${ }^{236} \mathrm{U}$ & 0.00636 & $\mathrm{~S} / \mathrm{E} / \mathrm{M}$ & $\begin{array}{l}\text { Based on ICP uranium sample result ratioed to } \\
\text { HDW estimates for uranium isotopes }\end{array}$ \\
\hline${ }^{237} \mathrm{~Np}$ & 1.92 & $\mathrm{M}$ & \\
\hline${ }^{238} \mathrm{Pu}$ & 6.45 & $\mathrm{~S} / \mathrm{E} / \mathrm{M}$ & $\begin{array}{l}\text { Based on total alpha activity sample result ratioed } \\
\text { to HDW estimates for alpha isotopes }\end{array}$ \\
\hline${ }^{238} \mathrm{U}$ & 0.185 & $\mathrm{~S} / \mathrm{E} / \mathrm{M}$ & $\begin{array}{l}\text { Based on ICP uranium sample result ratioed to } \\
\text { HDW estimates for uranium isotopes }\end{array}$ \\
\hline${ }^{239} \mathrm{Pu}$ & 222 & $\mathrm{~S} / \mathrm{E} / \mathrm{M}$ & $\begin{array}{l}\text { Based on total alpha activity sample result ratioed } \\
\text { to HDW estimates for alpha isotopes }\end{array}$ \\
\hline${ }^{240} \mathrm{Pu}$ & 37.6 & $\mathrm{~S} / \mathrm{E} / \mathrm{M}$ & $\begin{array}{l}\text { Based on total alpha activity sample result ratioed } \\
\text { to HDW estimates for alpha isotopes } \\
\end{array}$ \\
\hline${ }^{241} \mathrm{Am}$ & 269 & $\mathrm{~S} / \mathrm{E} / \mathrm{M}$ & $\begin{array}{l}\text { Based on total alpha activity sample result ratioed } \\
\text { to HDW estimates for alpha isotopes }\end{array}$ \\
\hline${ }^{241} \mathrm{Pu}$ & 436 & $\mathrm{~S} / \mathrm{E} / \mathrm{M}$ & $\begin{array}{l}\text { Based on total alpha activity sample result ratioed } \\
\text { to HDW estimates for alpha isotopes }\end{array}$ \\
\hline${ }^{242} \mathrm{Cm}$ & 0.689 & $\mathrm{~S} / \mathrm{E} / \mathrm{M}$ & $\begin{array}{l}\text { Based on total alpha activity sample result ratioed } \\
\text { to HDW estimates for alpha isotopes } \\
\end{array}$ \\
\hline${ }^{242} \mathrm{Pu}$ & 0.00239 & $\mathrm{~S} / \mathrm{E} / \mathrm{M}$ & $\begin{array}{l}\text { Based on total alpha activity sample result ratioed } \\
\text { to HDW estimates for alpha isotopes }\end{array}$ \\
\hline
\end{tabular}


Table D4-2. Best-Basis Inventory Estimates for Radioactive Components in Tank 241-SX-106 Decayed to January 1, 1994 (Effective May 31, 1998).

( 3 sheets)

\begin{tabular}{|c|c|c|c|}
\hline Analote & $\begin{array}{l}\text { Toul } \\
\text { muchtort } \\
\text { (e) }\end{array}$ & 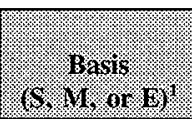 & Cominent \\
\hline${ }^{243} \mathrm{Am}$ & 0.00932 & $\mathrm{~S} / \mathrm{E} / \mathrm{M}$ & $\begin{array}{l}\text { Based on total alpha activity sample result ratioed } \\
\text { to HDW estimates for alpha isotopes }\end{array}$ \\
\hline${ }^{243} \mathrm{Cm}$ & 0.0638 & $\mathrm{~S} / \mathrm{E} / \mathrm{M}$ & $\begin{array}{l}\text { Based on total alpha activity sample result ratioed } \\
\text { to HDW estimates for alpha isotopes }\end{array}$ \\
\hline${ }^{244} \mathrm{Cm}$ & 0.630 & $\mathrm{~S} / \mathrm{E} / \mathrm{M}$ & $\begin{array}{l}\text { Based on total alpha activity sample result ratioed } \\
\text { to HDW estimates for alpha isotopes }\end{array}$ \\
\hline
\end{tabular}

Note:

'S = sample-based (see Appendix B), $M=H D W$ model based (Agnew et al. 1997), $E$ = engineering assessment based. 


\section{D5.0 APPENDIX D REFERENCES}

Agnew, S. F., J. Boyer, R. A. Corbin, T. B. Duran, J. R. Fitzpatrick, K. A. Jurgensen, T. P. Ortiz, and B. L. Young, 1997, Hanford Tank Chemical and Radionuclide Inventories: HDW Model Rev. 4, LA-UR-96-3860, Los Alamos National Laboratory, Los Alamos, New Mexico.

Hanlon, B. M., 1998, Waste Tank Summary Report for Month Ending May 31, 1998, HNF-EP-0182-122, Lockheed Martin Hanford Corp. for Fluor Daniel Hanford, Inc., Richland, Washington.

Hill, J. G., G. S. Anderson, and B. C. Simpson, 1995, The Sort on Radioactive Waste Type Model: A Method to Sort Single-Shell Tanks into Characteristic Groups, PNL-9814, Rev. 2, Pacific Northwest Laboratory, Richland, Washington

Hodgson, K. M. and M. D. LeClair, 1996, Work Plan for Defining a Standard Inventory Estimate for Wastes Stored in Hanford Site Underground Tanks, WHC-SD-WM-WP-311, Rev. 1, Lockheed Martin Hanford Corp. for Fluor Daniel Hanford, Inc., Richland, Washington.

Kummerer, M., 1995, Heat Removal Characteristics of Waste Storage Tanks, WHC-SD-WM-SARR-010, Rev. 1, Westinghouse Hanford Company, Richland, Washington.

Kupfer, M. J., A. L. Boldt, B. A. Higley, K. M. Hodgson, L. W. Shelton, B. C. Simpson, R. A. Watrous, M. D. LeClair, G. L. Borsheim, R. T. Winward, R. M. Orme, N. G. Colton, S. L. Lambert, D. E. Place, and W. W. Schulz, 1997, Standard Inventories of Chemicals and Radionuclides in Hanford Site Tank Wastes, HNF-SD-WM-TI-740, Rev. 0A, Lockheed Martin Hanford Corp. for Fluor Daniel Hanford, Inc., Richland, Washington.

LMHC, 1998, Best-Basis Inventory for Tank 241-SX-106, Tank Characterization Database, May 31, 1998, Internet at http://twins.pnl.gov:8001/TCD/main.html, Lockheed Martin Hanford Corp., Richland, Washington.

Sasaki, L. M., S. R. Wilmarth, and T. T. Tran, 1998, Tank Characterization Report for Single-Shell Tank 241-U-103, HNF-SD-WM-ER-712, Rev. 1, Lockheed Martin Hanford Corp. for Fluor Daniel Hanford, Inc., Richland, Washington.

Simpson, B. C., 1998, Best Basis Inventory Change Package for Reconciliation of Mercury Values, Change Package 7, (internal memorandum 7A120-98-005 to J. W. Cammann, February 26), Lockheed Martin Hanford Corp. for Fluor Daniel Hanford, Inc., Richland, Washington. 
Steen, F. H., 1998, Tank 241-SX-106, Cores 223 and 224, Analytical Results for the Final Report, HNF-SD-WM-DP-288, Rev. 0, Waste Management Federal Services of Hanford, Inc., for Fluor Daniel Hanford, Inc., Richland, Washington.

Watrous, R. A. and D. W. Wootan, 1997, Activity of Fuel Batches Processed Through Hanford Separations Plants, 1944 Through 1989, HNF-SD-WM-TI-794, Rev. 0, Lockheed Martin Hanford Corp. for Fluor Daniel Hanford, Inc., Richland, Washington. 
HNF-SD-WM-ER-645 Rev. 1

This page intentionally left blank. 
HNF-SD-WM-ER-645 Rev. 1

\section{APPENDIX E}

BIBLIOGRAPHY FOR TANK 241-SX-106

E-1 
HNF-SD-WM-ER-645 Rev. 1

This page intentionally left blank. 


\section{APPENDIX E \\ BIBLIOGRAPHY FOR TANK 241-SX-106}

Appendix E provides a bibliography of information that supports the characterization of tank 241-SX-106. This bibliography represents an in-depth literature search of all known information sources that provide sampling, analysis, surveillance, and modeling information, as well as processing occurrences associated with tank $241-\mathrm{SX}-106$ and its respective waste types.

The references in this bibliography are separated into three broad categories containing references broken down into subgroups. These categories and their subgroups are listed below.

\section{NON-ANALYTICAL DATA}

Ia. Models/Waste Type Inventories/Campaign Information

Ib. Fill History/Waste Transfer Records

Ic. Surveillance/Tank Configuration

Id. Sample Planning/Tank Prioritization

Ie. Data Quality Objectives/Customers of Characterization Data

\section{ANALYTICAL DATA - SAMPLING OF TANK WASTE AND WASTE TYPES}

IIa. Sampling of Tank 241-SX-106

IIb. Sampling of Similar Waste Types

\section{COMBINED ANALYTICAL/NON-ANALYTICAL DATA}

IIIa. Inventories Using Both Campaign and Analytical Information

IIIb. Compendium of Existing Physical and Chemical Documented Data Sources

This bibliography is broken down into the appropriate sections of material to use, with an annotation at the end of each reference, or set of references, describing the information source. Where possible, a reference is provided for information sources. A majority of the information listed below may be found in the Lockheed Martin Hanford Corp. Tank Characterization and Safety Resource Center. 


\section{NON-ANALYTICAL DATA}

\section{Ia. Models/Waste Type Inventories/Campaign Information}

Agnew, S. F., J. Boyer, R. A. Corbin, T. B. Duran, J. R. Fitzpatrick, K. A. Jurgensen, T. P. Ortiz, and B. L. Young, 1997, Hanford Tank Chemical and Radionuclide Inventories: HDW Model Rev. 4, LA-UR-96-3860, Los Alamos National Laboratory, Los Alamos, New Mexico.

- Contains waste type summaries, primary chemical compound/analyte and radionuclide estimates for sludge, supernatant, and solids, as well as SMM, TLM, and individual tank inventory estimates.

Anderson, J. D., 1990, A History of the 200 Area Tank Farms, WHC-MR-0132, Westinghouse Hanford Company, Richland, Washington.

- Contains single-shell tank fill history and primary campaign/waste type information to 1981 .

Jungfleisch, F. M., and B. C. Simpson, 1993, Preliminary Estimation of the Waste Inventories in Hanford Tanks Through 1980, WHC-SD-WM-TI-057, Rev. OA, Westinghouse Hanford Company, Richland, Washington.

- Describes a model for estimating tank waste inventories using process knowledge; radioactive decay estimates using ORIGEN; and assumptions about waste types, solubility, and constraints.

\section{Ib. Fill History/Waste Transfer Records}

Agnew, S. F., R. A. Corbin, T. B. Duran, K. A. Jurgensen, T. P. Ortiz, and B. L. Young, 1997, Waste Status and Transaction Record Summary (WSTRS) Rev. 4, LA-UR-97-311, Los Alamos National Laboratory, Los Alamos, New Mexico.

- Contains spreadsheets depicting all known tank additions/transfers.

Anderson, J. D., 1990, A History of the 200 Area Tank Farms, WHC-MR-0132, Westinghouse Hanford Company, Richland, Washington.

- Contains tank fill histories and primary campaign/waste type information to 1981. 


\section{Ic. Surveillance/Tank Configuration}

Alstad, A. T., 1993, Riser Configuration Document for Single-Shell Waste Tanks, WHC-SD-MW-TI-053, Rev. 9, Westinghouse Hanford Company, Richland, Washington.

- Shows riser location in relation to tank aerial view as well as a description of each riser and its contents.

Lipnicki, J., 1997, Waste Tank Risers Available for Sampling, HNF-SD-WM-TI-710, Rev. 4, Lockheed Martin Hanford Corp. for Fluor Daniel Hanford, Inc., Richland, Washington.

- Assesses riser locations for each tank; however, not all tanks are included/completed. Also includes an estimate of the risers available for sampling.

Tran, T. T., 1993, Thermocouple Status Single-Shell and Double-Shell Waste Tanks, WHC-SD-WM-TI-553, Rev. 0, Westinghouse Hanford Company, Richland, Washington.

- Provides thermocouple location and status information for double- and single-shell tanks.

Welty, R. K., 1988, Waste Storage Tank Status and Leak Detection Criteria, Volumes $I$ and II, WHC-SD-WM-TI-356, Rev. 0, Westinghouse Hanford Company, Richland, Washington.

- Provides leak detection information for all single- and double-shell tanks. Liquid level, liquid observation well, and dry well readings are included.

\section{Id. Sample Planning/Tank Prioritization}

Bates, J. M., 1997, Sampling Plan for Tank 241-SX-106 Retained Gas Sampler Deployment, TWSFG9772, Pacific Northwest National Laboratory, Richland, Washington.

- Contains the sampling scheme for core samples, using the RGS, to be taken from tank 241-SX-106. 
Brown, T. M., J. W. Hunt, and L. J. Fergestrom, 1997, Tank Characterization Technical Sampling Basis, WHC-SD-WM-TA-164, Rev. 3, Lockheed Martin Hanford Corp. for Fluor Daniel Hanford, Inc., Richland, Washington.

- Establishes an approach to determine the priority for tank sampling and characterization and identifies high priority tanks for sampling.

Jo, J., 1997, Tank 241-SX-106 Push Mode Core Sampling and Analysis Plan, HNF-SD-WM-TSAP-148, Rev. 1, Lockheed Martin Hanford Corp. for Fluor Daniel Hanford, Inc., Richland, Washington.

- Contains detailed sampling and analysis scheme for core samples to be taken from tank 241-SX-106 to address applicable DQOs.

Mulkey, C. H., 1996, Single-Shell Tank System Waste Analysis Plan, WHC-EP-0356, Rev. 1, Westinghouse Hanford Company, Richland, Washington.

- Waste analysis plan for single-shell tanks as required by WAC-173-303 and 40 CFR Part 265.

Stanton, G. A., 1998, Baseline Sampling Schedule, Change 98-01, (internal memorandum 79520-98-001 to Distribution, February 5), Lockheed Martin Hanford Corp. for Fluor Daniel Hanford, Inc., Richland, Washington.

- Provides a tank waste sampling schedule through fiscal year 2002 and lists samples taken since 1994.

Winkelman, W. D., 1996, Tank 241-SX-106 Tank Characterization Plan, WHC-SD-WM-TP-314, Rev. 2, Westinghouse Hanford Company, Richland, Washington.

- Discusses all relevant DQOs and how their requirements will be met for tank 241-SX-106.

Winkelman, W. D., M. R. Adams, T. M. Brown, J. W. Hunt, D. J. McCain, and L. J. Fergestrom, 1997, Fiscal Year 1997-1998 Waste Information Requirements Document, HNF-SD-WM-PLN-126, Rev. 0A, Lockheed Martin Hanford Corp. for Fluor Daniel Hanford, Inc., Richland, Washington. 
- Contains requirements from the Hanford Federal Facility Agreement and Consent Order, Recommendation 93-5 Implementation Plan, and other requirement sources that, along with managerial and operational constraints, are combined to summarize the TWRS characterization program deliverables for fiscal years 1997 and 1998.

\section{Ie. Data Quality Objectives/Customers of Characterization Data}

Bauer, R. E., and L. P. Jackson, 1998, Data Quality Objective to

Support Resolution of the Flammable Gas Safety Issue, WHC-SD-WM-DQO-004, Rev. 3A, DE\&S Hanford, Inc., for Fluor Daniel Hanford, Inc., Richland, Washington.

- Contains flammable gas program data needs, list of tanks to be evaluated, decision thresholds, and decision logic flow diagram.

Cash, R. J., 1996, Application of "Flammable Gas Tank Safety Program: Data Requirements for Core Sampling Analysis Developed Through the Data Quality Objective Process", Rev. 2, (internal memorandum 79300-96-028, to S. J. Eberlein, July 12), Westinghouse Hanford Company, Richland, Washington.

- Identifies single-shell tanks to use the retained gas sampling system.

DOE-RL, 1996, Recommendation 93-5 Implementation Plan, DOE/RL-94-0001, Rev. 1, U.S. Department of Energy, Richland Operations Office, Richland, Washington.

- Defines needs and milestones identified by the Defense Nuclear Facility Safety Board.

Dukelow, G. T., J. W. Hunt, H. Babad, and J. E. Meacham, 1995, Tank Safety Screening Data Quality Objective, WHC-SD-WM-SP-004, Rev. 2, Westinghouse Hanford Company, Richland, Washington.

- Determines whether tanks are under safe operating conditions.

Meacham, J. E., D. L. Banning, M. R. Allen, and L. D. Muhlestein, 1997, Data Quality Objective to Support Resolution of the Organic Solvent Safety Issue, HNF-SD-WM-DQO-026, Rev. 0, DE\&S Hanford, Inc., for Fluor Daniel Hanford; Inc., Richland, Washington.

- Contains requirements for the organic solvent DQO. 
Osborne, J. W., and L. L. Buckley, 1995, Data Quality Objectives for Tank Hazardous Vapor Safety Screening, WHC-SD-WM-DQO-002, Rev. 2, Westinghouse Hanford Company, Richland, Washington.

- Determines whether tank vapor spaces contain potentially hazardous gases and vapors.

Schreiber, R. D., 1997, Memorandum of Understanding for the Organic Complexant Safety Issue Data Requirements, HNF-SD-WM-RD-060, Rev. 0, Lockheed Martin Hanford Corp. for Fluor Daniel Hanford, Inc., Richland, Washington.

- Contains organic program data needs, list of tanks to be evaluated, decision thresholds, and decision logic flow diagram.

\section{ANALYTICAL DATA - SAMPLING OF TANK WASTE AND WASTE TYPES}

\section{IIa. Sampling of Tank 241-SX-106}

Brown, G. E., 1978, Concentration of Tank 106-SX Customer Waste, (internal letter 60120-78-149 to K. G. Carothers, December 22), Rockwell Hanford Operations, Richland, Washington.

- Contains historical sample analysis results.

Buckingham, J. S., 1977, Evaporation of Synthetic 106-SX Solution, (internal letter to R. E. Van der Cook, February 25), Atlantic Richfield Hanford Company, Richland, Washington.

- Contains historical sample analysis results.

Buckingham, J. S., 1977, Evaporator Support and Tank Farm Assistance, (internal letter to D. C. Lini, January 14), Atlantic Richfield Hanford Company, Richland, Washington.

- Contains historical sample analysis results.

Caprio, G. S., 1995, Vapor and Gas Sampling of Single-Shell Tank 241-SX-106 Using the Vapor Sampling System, WHC-SD-WM-RPT-145, Rev. 0, Westinghouse Hanford Company, Richland, Washington.

- Contains March 1995 vapor sample analysis results. 
Delegard, C. H., 1979, Viscosity/Cooling Curve for Tank 106-SX Sample Composite, (internal letter 65124-79-003 to H. J. Eding, November 1), Rockwell Hanford Operations, Richland, Washington.

- Contains historical sample analysis results.

Horton, J. E., 1977, Characterization of Tank 106-SX Supernatant and Sludge, (internal letter to W. R. Christensen, March 31), Atlantic Richfield Hanford Company, Richland, Washington.

- Contains historical supernatant and sludge sample analysis results.

Horton, J. E., 1977, Engineering Assistance Waste Concentration, (internal letter to D. C. Lini, June), Atlantic Richfield Hanford Company, Richland, Washington.

- Contains historical supernatant and sludge sample analysis results.

Horton, J. E., 1978, Analysis of 106-SX Tanks, Sample \#8301, (internal letter 60120-78-055 to R. J. Cain, June 29), Rockwell Hanford Operations, Richland, Washington.

- Contains historical sample analysis results.

Huckaby, J. L., and D. R. Bratzel, 1995, Tank 241-SX-106 Headspace Gas and Vapor Characterization Results for Samples Collected in March 1995, WHC-SD-WM-ER-460, Rev. 1, Westinghouse Hanford Company, Richland, Washington.

- Contains March 1995 vapor sample analysis results.

Klinger, G. S., T. W. Clauss, M. W. Ligotke, K. H. Pool, R. B. Lucke, B. D. McVeety, K. B. Olsen, O. P. Bredt, J. S. Fruchter, and S. C. Goheen, 1995, Vapor Space Characterization of Waste Tank 241-SX-106: Results from Samples Collected on 3/24/95, PNNL-10584, Pacific Northwest National Laboratory, Richland, Washington.

- Contains March 1995 vapor sample analysis results.

Lane, T. A., 1979, Customer Waste Flowsheet Development: Tank 106-SX, (internal letter 65120-79-133 J to D. R. Jorgenson, September 4), Rockwell Hanford Operations, Richland, Washington. 
- Contains historical sample analysis results.

Supervisor, Analytical Services, 1976, Analysis of Tank Farm Sample, Sample No: 6376, Tank 106-SX, Received 8/21/76, (internal letter), Atlantic Richfield Hanford Company, Richland, Washington.

- Contains historical sample analysis results.

Supervisor, Analytical Services, 1976, Analysis of Tank Farm Sample, Sample No: T7327, Tank 106-SX, Received 9/20/76, (internal letter), Atlantic Richfield Hanford Company, Richland, Washington.

- Contains historical sample analysis results.

Supervisor, Analytical Services, 1978, Analysis of Tank Farm Samples, Serial No: 5601, Tank 106 SX, Received 2/9/78, (internal letter to D. R. Autrey on March 6), Rockwell Hanford Operations, Richland, Washington.

- Contains historical sample analysis results.

Wheeler, R. E., 1974, Analysis of Tank Farm Samples, Sample: T-8041, 106-SX, (internal letter to R. L. Walser, December 6), Atlantic Richfield Hanford Company, Richland, Washington.

- Contains historical sample analysis results.

\section{IIb. Sampling of Similar Waste Types}

Bell, K. E., 1997, Tank Characterization Report for Single-Shell Tank 241-U-108, HNF-SD-WM-ER-639, Rev. 0A, Lockheed Martin Hanford Corp. for Fluor Daniel Hanford, Inc., Richland, Washington.

- Contains characterization data for the waste in tank 241-U-109, which includes SMMS1 and SMMS2 waste.

Brown, T. M., and J. Franklin, 1997, Tank Characterization Report for Single-Shell Tank 241-U-105, HNF-SD-WM-ER-617, Rev. 0A, Lockheed Martin Hanford Corp. for Fluor Daniel Hanford, Inc., Richland, Washington.

- Contains characterization data for the waste in tank 241-U-105, which includes SMMS2 waste. 
Campbell, G. D., 1975, 242-S Evaporator-Crystallizer Material Balance, (internal memorandum to R. L. Walker, August 5), Atlantic Richfield Hanford Company Operations, Richland, Washington.

- Contains chemical species material balance in support of the 242-S Evaporator.

Delegard, C. H., 1979, Customer Waste Flowsheet Development: Third Pass Run of Tank 106-SX/107-S Blend, (internal letter 65120-79-134 J to D. R. Jorgenson, September 5), Rockwell Hanford Operations, Richland, Washington.

- Contains historical sample analysis results in support of the 242-S Evaporator.

Eggers, R. F., R. H. Stephens, and T. T. Tran, 1997, Tank Characterization Report for Single-Shell Tank 241-S-102, HNF-SD-WM-ER-611, Rev. 0A, Lockheed Martin Hanford Corp. for Fluor Daniel Hanford, Inc., Richland, Washington.

- Contains characterization data for the waste in tank 241-S-102, which includes SMMS1 and SMMS2 waste.

Field, J. G., and B. A. Higley, 1997, Tank Characterization Report for Single-Shell Tank 241-U-109, HNF-SD-WM-ER-609, Rev. 0A, Lockheed Martin Hanford Corp. for Fluor Daniel Hanford, Inc., Richland, Washington.

- Contains characterization data for the waste in tank 241-U-109, which includes SMMS1 and SMMS2 waste.

Hu, T. A., 1997, Tank Characterization Report for Single-Shell Tank 241-U-102, HNF-SD-WM-ER-618, Rev. 0A, Lockheed Martin Hanford Corp. for Fluor Daniel Hanford, Inc., Richland, Washington.

- Contains characterization data for the waste in tank 241-U-102, which includes SMMS2 waste.

Jo, J., B. J. Morris, and T. T. Tran, 1997, Tank Characterization Report for Single-Shell Tank 241-U-107, HNF-SD-WM-ER-614, Rev. OA, Lockheed Martin Hanford Corp. for Fluor Daniel Hanford, Inc., Richland, Washington. 
- Contains characterization data for the waste in tank 241-U-107, which includes SMMS2 waste.

Puryear, D. A., and J. S. Buckingham, 1971, Status Report on Waste Solidification Studies and Separations Chemistry Laboratory, (internal memorandum to M. H. Campbell et al., Process Aids 00362, July 23), Atlantic Richfield Hanford Company Operations, Richland, Washington.

- Contains historical sample separation results in support of the 242-S Evaporator.

\section{COMBINED ANALYTICAL/NON-ANALYTICAL DATA}

\section{IIIa. Inventories Using Both Campaign and Analytical Information}

Agnew, S. F., R. A. Corbin, J. Boyer, T. B. Duran, K. A. Jurgensen, T. P. Ortiz, B. L. Young, R. Anema, and C. Ungerecht, 1996, History of Organic Carbon in Hanford HLW Tanks: HDW Model Rev. 3, LA-UR-96-989, Los Alamos National Laboratory, Los Alamos, New Mexico.

- Attempts to account for the disposition of soluble organics and provides estimates of TOC content for each tank.

Agnew, S. F., J. Boyer, R. A. Corbin, T. B. Duran, J. R. Fitzpatrick, K. A. Jurgensen, T. P. Ortiz, and B. L. Young, 1997, Hanford Tank Chemical and Radionuclide Inventories: HDW Model Rev. 4, LA-UR-96-3860, Los Alamos National Laboratory, Los Alamos, New Mexico.

- Contains waste type summaries, primary chemical compound/analyte and radionuclide estimates for sludge, supernatant, and solids, as well as SMM, TLM, and individual tank inventory estimates.

Allen, G. K., 1976, Estimated Inventory of Chemicals Added to Underground Waste Tanks, 1944 - 1975, ARH-CD-601B, Rev. 0, Atlantic Richfield Hanford Company, Richland, Washington.

- Contains major components for waste types and some assumptions. Purchase records are used to estimate chemical inventories. 
Brevick, C. H., J. L. Stroup, and J. W. Funk, 1997, Historical Tank Content Estimate for the Southwest Quadrant of the Hanford 200 East Area, WHC-SD-WM-ER-352, Rev. 1, Fluor Daniel Northwest, Inc., for Fluor Daniel Hanford, Inc., Richland, Washington.

- Contains summary information for tanks in S, SX and U Tank Farms as well as in-tank photograph collages and inventory estimates.

Klem, M. J., 1988, Inventory of Chemicals Used at Hanford Production Plants and Support Operations (1944 - 1980), WHC-EP-0172, Westinghouse Hanford Company, Richland, Washington.

- Provides a list of chemicals used in production facilities and support operations that sent wastes to the single-shell tanks. List is based on chemical process flowsheets, essential materials consumption records, letters, reports, and other historical data.

Kupfer, M. J., A. L. Boldt, B. A. Higley, K. M. Hodgson, L. W. Shelton, B. C. Simpson, R. A. Watrous, M. D. LeClair, G. L. Borsheim, R. T. Winward, R. M. Orme, N. G. Colton, S. L. Lambert, D. E. Place, and W. W. Schulz, 1997, Standard Inventories of Chemicals and Radionuclides in Hanford Site Tank Wastes, HNF-SD-WM-TI-740, Rev. 0A, Lockheed Martin Hanford Corp. for Fluor Daniel Hanford, Inc., Richland, Washington.

- Contains a global component inventory for 200 Area waste tanks' major constituents.

Schmittroth, F. A., 1995, Inventories for Low-Level Tank Waste, WHC-SD-WM-RPT-164, Rev. 0, Westinghouse Hanford Company, Richland, Washington.

- Contains a global inventory based on process knowledge and radioactive decay estimations using ORIGEN2. Plutonium and uranium waste contributions are taken at one percent of the amount used in processes. Also compares information on ${ }^{99} \mathrm{Tc}$ from both ORIGEN2 and analytical data.

Toth, J. J., C. E. Willingham, P. G. Heasler, and P.D. Whitney, 1994, Organic Carbon in Hanford Single-Shell Tank Waste, PNL-9434, Pacific Northwest Laboratory, Richland, Washington.

- Contains organic carbon analytical results and model estimates for tanks. 


\section{IIIb. Compendium of Existing Physical and Chemical Documented Data Sources}

Agnew, S. F., and J. G. Watkin, 1994, Estimation of Limiting Solubilities for Ionic Species in Hanford Waste Tank Supernates, LA-UR-94-3590, Los Alamos National Laboratory, Los Alamos, New Mexico.

- Document gives solubility ranges used for key chemical and radionuclide components based on supernate sample analyses.

Brevick, C. H., L. A. Gaddis, and E. D. Johnson, 1996, Tank Waste Source Term Inventory Validation, Vol I, II, and III, WHC-SD-WM-ER-400, Rev. OA, Westinghouse Hanford Company, Richland, Washington.

- Contains a quick reference to sampling information in spreadsheet or graphical form for 24 chemicals and 11 radionuclides for all the tanks.

Brevick, C. H., J. L. Stroup, and J. W. Funk, 1997, Supporting Document for the Historical Tank Content Estimate for SX-Tank Farm, WHC-SD-WM-ER-324, Rev. 1, Fluor Daniel Northwest, Inc., for Fluor Daniel Hanford, Inc., Richland, Washington.

- Contains summary information for tanks in the SX Tank Farm and appendices containing more detailed information including tank waste level history, tank temperature history, cascade and dry well charts, riser information, in-tank photograph collages, and tank layer model bar chart and spreadsheet.

Claybrook, S. W., 1993, An Evaporation Analysis for Tanks 241-SX-103, 241-SX-105, and 241-SX-106, Westinghouse Hanford Company, Richland, Washington.

- Contains analysis of evaporation of waste from specific tanks.

Hanlon, B. M., 1998, Waste Tank Summary Report for Month Ending May 31, 1998, HNF-EP-0182-122, Lockheed Martin Hanford Corp. for Fluor Daniel Hanford, Inc., Richland, Washington.

- Updated monthly, contains a summary of tank waste volumes, watch list tanks, occurrences, tank integrity information, equipment readings, tank location, leak volumes, and other miscellaneous tank information. 
Hill, J. G., G. S. Anderson, and B. C. Simpson, 1995, The Sort on Radioactive Waste Type Model: A Method to Sort Single-Shell Tanks into Characteristic Groups, PNL-9814, Rev. 2, Pacific Northwest Laboratory, Richland, Washington.

- Describes a system of sorting single-shell tanks into groups based on the major waste types contained in each tank.

Husa, E. I., R. E. Raymond, R. K. Welty, S. M. Griffith, B. M. Hanlon, R. R. Rios, and N. J. Vermeulen, 1993, Hanford Site Waste Storage Tank Information Notebook, WHC-EP-0625, Rev. 0, Westinghouse Hanford Company, Richland, Washington.

- Contains in-tank photographs and summaries of the tank description, leak detection system, and tank status.

Husa, E. I., 1995, Hanford Waste Tank Preliminary Dryness Evaluation, WHC-SD-WM-TI-703, Rev. 0, Westinghouse Hanford Company, Richland, Washington.

- Assesses the relative dryness of tank wastes.

LMHC, 1998, Tank Characterization Data Base, Internet at http://twins.pnl.gov:8001/TCD/main.html, Lockheed Martin Hanford Corp., Richland, Washington.

- Contains analytical data for each of the 177 Hanford Site waste tanks.

Shelton, L. W., 1995, Chemical and Radionuclide Inventory for Single- and Double-Shell Tanks, (internal memorandum 75520-95-007 to R. M. Orme, August 8), Westinghouse Hanford Company, Richland, Washington.

- Contains a tank inventory estimate based on analytical information.

Shelton, L. W., 1995, Radionuclide Inventories for Single- and Double-Shell Tanks, (internal memorandum 71320-95-002 to F. M. Cooney, February 14), Westinghouse Hanford Company, Richland, Washington.

- Contains a tank inventory estimate based on analytical information. 
Shelton, L. W., 1996, Chemical and Radionuclide Inventory for Single- and Double-Shell Tanks, (internal memorandum 74A20-96-30 to D. J. Washenfelder, February 28), Westinghouse Hanford Company, Richland, Washington.

- Contains a tank inventory estimate based on analytical information.

Van Vleet, R. J., 1993, Radionuclide and Chemical Inventories for the SingleShell Tanks, WHC-SD-WM-TI-565, Rev. 1, Westinghouse Hanford Company, Richland, Washington.

- Contains selected sample analysis tables before 1993 for single-shell tanks. 
DISTRIBUTION SHEET

\begin{tabular}{|c|c|c|c|c|c|}
\hline \multirow[b]{2}{*}{ Distribution } & \multirow{2}{*}{\multicolumn{3}{|c|}{$\begin{array}{c}\text { Data } \\
\text { Int }\end{array}$}} & \multicolumn{2}{|l|}{ Page 1 of 2} \\
\hline & & & & \multicolumn{2}{|c|}{ Date $\quad 09 / 09 / 98$} \\
\hline \multicolumn{4}{|c|}{ Project Title/Work Order } & \multicolumn{2}{|l|}{ EDT No. $N / A$} \\
\hline \multicolumn{4}{|c|}{$\begin{array}{l}\text { Tank Characterization Report for Single-She11 Tank 241-SX-106, } \\
\text { HNF-SD-WM-ER-645, Rev. } 1\end{array}$} & \multicolumn{2}{|c|}{ ECN No. $\quad$ ECN-643829 } \\
\hline Name & MSIN & $\begin{array}{c}\text { Text } \\
\text { With All } \\
\text { Attach. }\end{array}$ & Text Only & $\begin{array}{l}\text { Attach./ } \\
\text { Appendix } \\
\text { Only }\end{array}$ & $\begin{array}{l}\text { EDT/ECN } \\
\text { Only }\end{array}$ \\
\hline
\end{tabular}

OFFSITE

Sandia Nationa 7 Laboratory

P.0. Box 5800

MS-0744, Dept. 6404

Albuquerque, NM 87815

D. Powers

Nuclear Consulting Services Inc.

P. 0. Box 29151

Columbus, OH 43229-01051

J. L. Kovach

$x$

Chemical Reaction Sub-TAP

P.0. Box 271

Lindsborg, KS 67456

B. C. Hudson

SAIC

555 Quince Orchard Rd., Suite 500

Gaithersburg, MD 20878-1437

H. Sutter

$x$

Los ATamos Laboratory

CST-14 MS-J586

P. 0 . Box 1663

Los Alamos. NM 87545

S. F. Agnew

$x$

Tank Advisory Panel

102 Windham Road

Oak Ridge. TN 37830

D. 0. Campbe11 


\section{DISTRIBUTION SHEET}

\begin{tabular}{|c|c|c|c|c|c|}
\hline \multirow[b]{2}{*}{ Distribution } & \multirow{2}{*}{\multicolumn{3}{|c|}{$\begin{array}{l}\text { Data } A \\
\text { Int }\end{array}$}} & \multicolumn{2}{|l|}{ Page 2 of 2} \\
\hline & & & & Date & $9 / 98$ \\
\hline \multicolumn{4}{|l|}{ Project Title $/$ Work Order } & \multicolumn{2}{|c|}{ EDT No. N/A } \\
\hline \multicolumn{4}{|c|}{$\begin{array}{l}\text { Tank Characterization Report for Single-She11 Tank 241-SX-106, } \\
\text { HNF-SD-WM-ER-645, Rev. } 1\end{array}$} & \multicolumn{2}{|c|}{ ECN No. ECN-643829 } \\
\hline \multicolumn{2}{|l|}{ Name } & $\begin{array}{c}\text { Text } \\
\text { With All } \\
\text { Attach. }\end{array}$ & Text Only & $\begin{array}{l}\text { Attach./ } \\
\text { Appendix } \\
\text { Only }\end{array}$ & $\begin{array}{l}\text { EDT/ECN } \\
\text { Only }\end{array}$ \\
\hline
\end{tabular}

\section{ONSITE}

Department of Energy - Richland Operations

J. F. Thompson

W. S. Liou

J. A. Poppiti

$57-54$

$57-54$

S7-54

$\stackrel{x}{x}$

X

DE\&S Hanford, Inc.

W. L. Cowley

G. D. Johnson

R1-49 . $\quad X$

S7-73 $\quad x$

Fluor Daniel Northwest

E. D. Johnson

S2-47 $\quad X$

Lockheed Martin Hanford, Corp.

J. G. Burton

J. W. Cammann

S7-21

$\mathrm{R} 2-11$

$\mathrm{R} 2-12$

J. G. Field

J. Jo

W. E. Ross

L. M. Sasaki

B. C. Simpson

R. R. Thompson

ERC (Environmental Resource Center)

T.C.S.R.C.

$\mathrm{R} 2-12$

S7-84

$\mathrm{R} 2-12$

$\mathrm{R} 2-12$

$\mathrm{R} 2-12$

R1-51

R1-10

$x$
$X$
$X$
$x$
$x$
$x$
$x$
$x$
$x$
5

Lockheed Martin Services. Inc.

B. G. Lauzon

Central Files

EDMC

R1-08 X

B1-07 $\quad X$

H6-08 . X

Numatec Hanford Corporation

J. S. Garfield

D. L. Herting

J. S. Hertzel

D. L. Lamberd

H5- 49

T6-07

H5-61

H5-61

$x$
$X$
$x$
$x$

Pacific Northwest National Laboratory

A. F. Noonan

K9-91 X 